\author{
UNIVERSIDADE DE SÃO PAULO \\ FACULDADE DE FILOSOFIA, LETRAS E CIÊNCIAS HUMANAS \\ DEPARTAMENTO DE HISTÓRIA \\ PROGRAMA DE PÓS-GRADUAÇÃO EM HISTÓRIA SOCIAL
}

\title{
Entre a ditadura e a democracia: \\ história oral de vida acadêmica (FFLCH-USP).
}

Glauber Cícero Ferreira Biazo

V. 1

São Paulo

2014 
UNIVERSIDADE DE SÃO PAULO

FACULDADE DE FILOSOFIA, LETRAS E CIÊNCIAS HUMANAS

DEPARTAMENTO DE HISTÓRIA

PROGRAMA DE PÓS-GRADUAÇÃO EM HISTÓRIA SOCIAL

\title{
Entre a ditadura e a democracia: história oral de vida acadêmica (FFLCH-USP).
}

\begin{abstract}
Glauber Cícero Ferreira Biazo
Tese apresentada ao Programa de Pósgraduação em História Social da Faculdade de Filosofia Letras e Ciências Humanas da Universidade de São Paulo, para a obtenção do título de doutor em História.
\end{abstract}

Orientador: Prof. Dr. José Carlos Sebe Bom Meihy

V. 1

São Paulo

2014 
Para Joana Campos Clímaco

Para meus pais

Para Joana Martins Ferreira in memoriam 


\section{Agradecimentos}

Meu agradecimento inicial dirige-se ao grande mestre Prof. Dr. José Carlos Sebe Bom Meihy. Sua dedicação e respeito ao ensino público e a esta Faculdade de Filosofia foram marcantes em minha trajetória.

Agradeço imensamente a todos os docentes colaboradores que concederam as entrevistas sem as quais esta pesquisa não poderia ser feita: Ana Fani Alessandri Carlos, Benjamin Abdala Júnior, Davi Arrigucci Júnior, Eunice Ribeiro Durham, Francisco Maria Cavalcanti de Oliveira, Franklin Leopoldo e Silva, Janice Theodoro da Silva, José Álvaro Moisés, José Augusto Guilhon de Albuquerque, Leyla Perrone-Moisés, Mário Miguel González, Olgária Chain Feres Matos, Osvaldo Luis Angel Coggiola, Renato Janine Ribeiro, Sandra Guardini Teixeira Vasconcelos, Sandra Margarida Nitrini, Sérgio França Adorno de Abreu, Wanderley Messias da Costa e Zilda Márcia Grícoli Iokoi. Por meio deste agradecimento, faço também uma homenagem a todos os professores que contribuíram para minha formação.

Agradeço aos amigos e pesquisadores do Núcleo de Estudos em História Oral da USP pelo convívio universitário: Andrea Paula dos Santos, Archimedes Silva, Eduardo Maranhão, Fabíola Holanda, Fernanda Guimarães, Leandro Seawright, Lourival dos Santos, Marcel Diego Tonini, Márcia Mura, Marcela Evangelista, Thomas Monteiro, Vanessa Paes, Vanessa Rojas e Suzana Ribeiro. À Marta Rovai, meu "muito obrigado" pelo trabalho compartilhado e generosidade acadêmica.

Agradeço ao Prof. Dr. Júlio César Suzuki e ao Prof. Dr. Marcos Napolitano pelas leituras atentas e generosas contribuições durante o exame de qualificação.

Agradeço à Prof. ${ }^{a}$ Dra. Sandra Nitrini e ao Prof. Dr. Sérgio Adorno que, como diretores da Faculdade de Filosofia, Letras e Ciências Humanas, concederam acesso aos memoriais escritos pelos docentes. Ao agradecer à Maria da Luz, faço também menção a todos os funcionários do Serviço de Expediente desta instituição que viabilizaram a pesquisa.

Agradeço aos professores Ana Marisa Valim, Célia Avanzi, Daniel Giandoso, Denise Cavenaghi, Gustavo Lopes, Joana Clímaco, Luis Marcos Ferreira, Marcelo Rocha Campos, Renata Tamaso, Samantha Lodi e Sueli Barzon, colegas e amigos que 
contribuíram na construção do Curso de Licenciatura em História das Faculdades Integradas Maria Imaculada (FIMI).

Agradeço ao Prof. Rodrigo H. de Almeida pelo companheirismo e dedicação na concretização de projetos coletivos. Ao Prof. Romildo Morelato Júnior, diretor do centro de Mogi Guaçu das FIMI, pelo apoio institucional concedido. À Meire e Sueli pelo esforço incansável em sanar as atribulações burocráticas.

Sou especialmente grato aos alunos de Pedagogia e História das FIMI pelo conhecimento compartilhado e por compreenderem os momentos de ausência.

Agradeço ao Prof. Rogério Lopes Pinheiro de Carvalho pelo diálogo e pelas importantes contribuições durante a fase inicial da pesquisa. Ao Prof. Miguel Palmeira pelas sugestões de leitura. Ao Prof. Cássio de Araújo Duarte pelo constate incentivo.

Aos amigos de Sampa: Rafaela Deiab, Kleber Valadares, Adriano Damas, Wellington de Mello, Lígia Feichas, Gonzalo Castelnuovo, Maíra Volpi e Eduardo Dimitrov.

Ao Dr. Mário José Abdalla Saad e à Dra. Maria Cândida Ribeiro Parisi, ambos docentes e pesquisadores da Faculdade de Medicina da Unicamp, por me recolocarem na estrada.

Agradeço aos meus sogros Rosana e João Carlos. À Eliana Stockler, à Júlia, Alexandre, Leonardo e Aninha. À Denise e ao Júlio Pastore.

Aos meus pais Célia e Angelo pelo apoio incondicional.

À Joana, por toda jornada. Nas andanças por esse mundão afora, como é bom estar ao seu lado e compartilhar histórias! 
Numa palavra, todo mundo se conhecia e São Paulo aparecia ainda como uma cidade docemente provinciana. Ninguém imaginava, creio, nesses anos 50, como o crescimento demográfico em surdina iria repercutir logo a seguir nesse pequeno mundo, transformando tão rápida e radicalmente a Universidade e o estilo da boemia intelectual. Em menos de uma década, nossa Escola tornou-se uma Universidade de massa e nossos bares foram varridos do centro da cidade. Em meados da década de 60 , já havíamos perdido nossa pátria paulistana. A cidade, portanto, desprovincianizou-se, para bem de sua vida cultural, cada vez mais "profissional".

Bento Prado Júnior. "A biblioteca e os bares na década de 50". Fazenda Jandaia, 14/01/1988. 


\section{Resumo}

Dezenove entrevistas realizadas com professores titulares pertencentes à Faculdade de Filosofia, Letras e Ciências Humanas da Universidade de São Paulo, permitiram examinar a construção de uma memória coletiva sobre o papel desta instituição na transição política da ditadura para a democracia no Brasil.

As histórias de vida possibilitaram investigar como os docentes se apropriaram do processo de profissionalização acadêmica determinado pela Lei 5540/68. O objetivo desta tese é demonstrar como o fim das cátedras e a conquista de uma autonomia intelectual baseada na carreira pública foram responsáveis por reorientar os projetos coletivos e resignificar as relações estabelecidas pelos professores com a sociedade no período democrático.

A reintrodução da questão democrática no final dos anos 1970 trouxe à tona pautas políticas divergentes que explicitaram diferentes concepções a respeito da função dos intelectuais na sociedade. A intenção desta pesquisa é evidenciar como a comunidade docente forjada em um contexto de modernidade radicalizada, reiterou seu compromisso na defesa do ensino público e o desejo de interferir nos destinos do país.

Palavras-chave: Democracia; Ditadura; Docentes; Faculdade de Filosofia, Letras e Ciências Humanas (FFLCH-USP); História do Brasil; História Oral e Intelectuais. 


\begin{abstract}
The realization of nineteen interviews with full professors from the Faculty of Philosophy, Language and Human Sciences (FFLCH) in the University of São Paulo provided the possibility to examine the construction of a collective memory concerning the role of this institution in the political transition from dictatorship to democracy in Brazil.

The paths of intellectual life allowed the investigation of how the professors appropriated the process of academic professionalization determined by the Law 5540/68. The aim of this thesis is to demonstrate the way the end of the professorship and the conquest of intellectual autonomy based on a public career were responsible to redirect the collective projects and revaluate the relations established between professors and society in the democratic period.

The reintroduction of the democratic issue in the end of the seventies brought to light divergent political contexts that emphasized different conceptions related to the function of intellectuals in society. The objective of this research is to clarify how the docent community established in a context of radical modernity reaffirmed its commitment in defense of public education and the desire to interfere in the destinies of the country.
\end{abstract}

Key-Words: Democracy; Dictatorship, Docents, Faculty of Philosophy, Language and Human Sciences (FFLCH-USP); History of Brazil; Oral History and Intellectuals. 


\section{Sumário}

$\begin{array}{ll}\text { Introdução } & 10\end{array}$

Comunidade de destino: identidade e coletividade. 11

$\begin{array}{ll}\text { A história oral de vida acadêmica. } & 15\end{array}$

Introdução às histórias de vida dos colaboradores. $\quad 21$

$\begin{array}{ll}\text { Os colaboradores. } & 23\end{array}$

Capítulo 1: A formação de uma comunidade docente entre a ditadura e a democracia. 41

1.1 Origens da Faculdade de Filosofia da Universidade de São Paulo. 41

1.2 Uma comunidade docente entre duas culturas universitárias. 51

1.3 A presença da Maria Antônia na memória coletiva da comunidade docente. $\quad 61$

1.3.1 A formação básica.

1.3.2 O contexto sociocultural e político. $\quad 67$

$\begin{array}{ll}1.4 \text { Memória sobre a repressão. } & 78\end{array}$

1.5 A Faculdade de Filosofia em trânsito. 93

1.6 A Faculdade de Filosofia e a profissionalização da carreira acadêmica. $\quad 98$

1.7 Uma comunidade acadêmica forjada entre duas culturas políticas. 110

Capítulo 2: Uma comunidade docente em transição no contexto democrático. 115

2.1 Os intelectuais e a (re)introdução da questão democrática. 116

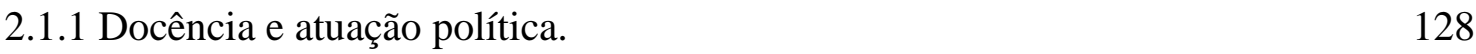

2.1.2 Trajetórias individuais de uma coletividade em transição. 132

2.1.3 Produção acadêmica: avaliação docente e produtivismo. 152

$\begin{array}{ll}2.2 \text { Uma casa aquinhoada. } & 181\end{array}$

Capítulo 3 - Entre a profissão e a docência: memória coletiva e universidade pública. 191

3.1 Intelectuais e espaço público em debate. 191

3.2 Memória coletiva e compromisso público. 210

3.3 Diálogo e autonomia: a difícil mediação entre universidade e sociedade. $\quad 222$

$\begin{array}{ll}\text { Apontamentos Finais } & 238\end{array}$

$\begin{array}{lr}\text { Referências Bibliográficas } & 242\end{array}$ 


\section{Introdução}

Os intelectuais se tornaram uma preocupação a partir do momento em que comecei a dar aulas em uma Faculdade responsável pela formação de professores em 2004. Acabara de concluir o mestrado em História Social e a oportunidade para ministrar as disciplinas de História e Sociologia da Educação mantinha viva a necessidade da pesquisa em conjunto com a prática docente. No processo de definição das ementas, dos objetivos, temas e autores, um texto passou a fazer parte dos programas da disciplina de Sociologia em todos os semestres: "A formação política e o trabalho do professor" de Florestan Fernandes ${ }^{1}$.

Fernandes procurou nesse texto fazer uma avaliação crítica das prioridades e dicotomias existentes no mundo acadêmico durante o período de sua formação e enquanto atuou como professor na Faculdade de Filosofia, Letras e Ciências da Universidade de São Paulo até o momento em que passou a ser investigado e, finalmente, compulsoriamente aposentado após o AI-5. A principal questão levantada por Florestan a respeito das décadas de 1940 e 1950 diz respeito à concepção do professor universitário enquanto intelectual acima da sociedade. Dessa maneira, o artigo questiona o modelo ideal de cientista da época, que atuava transmitindo conceitos e propondo avaliações "politicamente neutras" em relação a seus objetos e, principalmente, a sociedade. Falando para alunos universitários no final da década de 1970, Fernandes considerava a formação política condição indispensável para a construção de uma república plenamente democrática no país e propunha uma nova concepção de autonomia intelectual.

Ingressei como aluno do curso de Licenciatura em História da Faculdade de Filosofia, Letras e Ciências Humanas da Universidade de São Paulo (FFLCH-USP) no mesmo ano em que Florestan Fernandes faleceu. O ano de 1995 foi marcado por mesas

\footnotetext{
${ }^{1}$ Em entrevista à Prof. ${ }^{\text {a }}$ Maria Arminda do Nascimento Arruda, Florestan Fernandes afirmou: "Não pretendia voltar nem à condição de professor, nem aos temas acadêmicos. Depois de 1969, a minha identificação com a Sociologia e com os papéis intelectuais do sociólogo sofreu uma crise. Para ficarmos no essencial: a Sociologia perdeu o seu encanto para mim; o sociólogo profissional converteu-se numa pessoa que luta mais para sobreviver e ganhar a vida - enfim, para preservar e reforçar a sua condiçãozinha de classe média - do que pela perda inerente à natureza científica e, portanto, revolucionária da explicação sociológica". Apud: ARRUDA, M. A. do N. Metrópole e Cultura - São Paulo no meio século XX. Bauru, EDUSC, 2001. Ver também: FERNANDES, F. A Sociologia no Brasil contribuição para o estudo de sua formação e desenvolvimento. Petrópolis: Vozes, 1976. Especialmente os capítulos "A Sociologia como contestação" e "Sociologia e Socialismo".
} 
redondas que discutiram sua trajetória e seus livros, bem como artigos e homenagens foram publicados. Paralelamente aos eventos, as aulas de Brasil Colonial da Prof. ${ }^{\text {a Ilana }}$ Blaj demonstravam a importância e o vigor teórico e político de sua contribuição como sociólogo e intelectual disposto a compreender a formação e as contradições da sociedade brasileira. Desde então, pude acompanhar durante a graduação e o mestrado o fim da dupla graduação na USP, a diminuição do número de professores, salas superlotadas, a consolidação de novos modelos tecnoburocráticos de avaliação do trabalho acadêmico, a diminuição dos prazos para a realização de mestrados e doutorados e um debate cada vez mais intenso a respeito da importância da universidade pública estreitar suas relações com o setor produtivo. As tensões cotidianas vividas dentro da universidade eram, cada vez mais explicitamente, parte de um conjunto de disputas travadas no plano político-ideológico, tanto na esfera do Estado como na sociedade civil.

A partir dessa experiência como aluno e pesquisador da FFLCH-USP, tenho trabalhado nessa pesquisa a respeito da trajetória de vida acadêmica dos professores titulares dessa instituição em atividade entre os anos de 1976 e 2012. A investigação consiste em compreender a gênese e a trajetória intelectual dos professores titulares da FFLCH-USP a partir de entrevistas de história oral de vida realizadas com 19 docentes e apoio dos memoriais entregues no ato da inscrição para o concurso de titulação (MS$6)$.

\section{Comunidade de destino: identidade e coletividade.}

Partindo das concepções teóricas de história oral desenvolvidas por José Carlos Sebe Bom Meihy, foram entrevistados docentes titulares da Faculdade de Filosofia, Ciências e Letras da USP entendendo-os como parte integrante de uma comunidade de destino $^{2}$. O que, em outras palavras, significa que esses professores possuem uma experiência em comum: a de fazerem parte de uma instituição de ensino (professores, pesquisadores e funcionários públicos), compartilhando responsabilidades em uma

\footnotetext{
2 Para Meihy, "Comunidade de destino é o resultado de uma experiência que qualifica um grupo, articulando princípios que orientam suas atitudes de maneira a configurar uma coletividade com base identitária”. Ver: MEIHY, J. C. S. B. Manual de História Oral. São Paulo: Loyola, 2005, p.72.
} 
mesma carreira profissional entre 1976 e 2013. Assim, a comunidade de destino dos docentes da FFLCH-USP foi aqui investigada a partir das experiências compartilhadas durante um mesmo contexto sócio-econômico e histórico de transição política trançada da ditadura para a democracia. A fundação da Associação dos Docentes da Universidade de São Paulo (ADUSP) em 1976 e a publicação do Livro Negro da USP foi o referencial adotado como marco de um longo e controverso processo. Porém, a temporalidade que interessa à pesquisa é aquela concedida pelas histórias de vida dos docentes que se titularam no período apontado e, portanto, abrange experiências construídas em momentos anteriores indicados pela baliza inicial ${ }^{3}$.

O trabalho teve início a partir de um levantamento do número de professores titulares que defenderam a "titulatura" entre 1976 e 2012. Realizada junto ao Setor de Recursos Humanos da FFLCH-USP, a listagem fornecida apontou em 185 o número de professores titulares somados os 11 departamentos de História, Geografia, Sociologia, Antropologia, Ciência Política, Filosofia, Letras Modernas, Linguística, Letras Clássicas e Vernáculas, Teoria Literária e Literatura Comparada e Letras Orientais.

O passo seguinte, entre agosto de 2010 e julho de 2011, consistiu na leitura de uma série de memoriais apresentados pelos professores no ato de inscrição para o concurso de titular. A grande maioria dos memoriais apresentados até 2006 não foi disponibilizada ao público nas bibliotecas da universidade e precisou ser requisitada ao Setor de Expediente, localizado no Prédio da Administração da FFLCH-USP. Os memoriais apresentados no período anterior a 1988 possuem o formato de currículos simples e, assim, não atenderam às expectativas enquanto fontes significativas e capazes de explicitar informações sobre as decisões acadêmicas, ou mesmo, a respeito do cotidiano vivido na universidade, portanto não foram fichados e integrados às fontes. A compulsão inicial dos documentos indicou que os memoriais entregues posteriormente ao Estatuto de 1988 deixaram de ser uma simples organização da produção curricular. Desde então, passaram a ser elaborados em forma narrativa, através da qual os detalhes cotidianos da trajetória acadêmica podem ser entendidos como uma devolução pública do trabalho acadêmico desenvolvido ao longo de suas carreiras.

Os memoriais apresentados depois de 1988 constituíram um núcleo documental germinal para uma primeira aproximação em relação às trajetórias acadêmicas dos professores titulares e dos seus vínculos em relação aos acontecimentos políticos que

\footnotetext{
${ }^{3}$ ADUSP. O controle ideológico na USP (1964-1978). São Paulo: ADUSP, 2004.
} 
marcaram a universidade e o país nos últimos quarenta $\operatorname{anos}^{4}$. Como documentos autobiográficos, seu conteúdo faz referência ao próprio sentido da rememoração e está relacionado ao fato da sua redação ser também um acerto de contas com a trajetória pessoal de cada um. Nas palavras de Georges Gusdorf, a autobiografia é um ato de tomada de consciência, "uma segunda leitura da experiência e mais verdadeira que a primeira". A presente tese, no entanto, concentrou-se na formulação e na análise das entrevistas de história oral de vida acadêmica, enquanto os memoriais permaneceram como fontes de apoio.

A partir do levantamento de todos os professores da Faculdade de Filosofia que defenderam a "titulatura" entre 1976 e 2012, era preciso definir quais deles seriam entrevistados. Desde o início da pesquisa considerou-se necessário dialogar com todas as áreas de formação presentes na FFLCH-USP. Desse modo, os diferentes departamentos foram tomados como "redes" que permitiriam uma visão panorâmica e, ao mesmo tempo, específica e promotora de diferentes perspectivas. Foram enviados convites aos professores titulares de todos os departamentos explicando os objetivos da pesquisa e a centralidade de sua participação.

A partir dos contatos estabelecidos, delimitou-se em 20 o conjunto de colaboradores que participariam da elaboração da pesquisa. A escolha final dos docentes que foram entrevistados utilizou como critério a necessidade de ouvir professores em exercício e também aposentados, homens e mulheres e, no mínimo, dois representantes de cada departamento que compõe a FFLCH-USP. Entre os muitos emails enviados houve 5 recusas e em torno de 15 e-mails não respondidos, o que impediu, por exemplo, que o Departamento de Letras Orientais fosse contemplado. A vigésima entrevista também não pôde ser realizada devido à finalização do prazo para a conclusão do trabalho. Todas as entrevistas elaboradas compõem o volume 2 desta obra

\footnotetext{
${ }^{4}$ Definidos os professores titulares da FFLCH-USP como comunidade de destino da pesquisa, realizou-se um levantamento de todos os professores que assumiram o cargo de professores titulares (MS-6) na FFLCH-USP entre os anos de 1976 e 2011. Ao todo, defenderam a titulatura nesse período 185 professores. O levantamento foi realizado junto à unidade de Recursos Humanos da Administração da FFLCH-USP. A escolha dos titulares se deveu ao fato de serem os primeiros professores a galgarem a nova carreira organizada com a decretação do fim das cátedras, a saber: Auxiliar de Ensino: MS-1; Assistente: MS-2; Professor doutor: MS-3; Professor Associado: MS-5; e Professor Titular: MS-6.

${ }^{5}$ Para Georges Gusdorf, "la autobiografia es una segunda lectura de la experiencia, y mas verdadera que la primera, puesto que es toma de conciencia: em la inmediatez de lo vivido, me envuelve generalmente el dinamismo de la situación, impidiéndome ver el todo. La memoria me concede perspectiva y me permite tomar em consideración las complejidades de la situación, en el tiempo y em el espacio”. In: GUSDORF, G. "Condiciones y limites de la autobiografia”. In: ANTHROPOS, Madri, Dez. de 1991, p.13.
} 
e foram conferidas e aprovadas pelos narradores. O quadro a seguir apresenta os 19 docentes que colaboraram com esta pesquisa e seus respectivos departamentos:

\begin{tabular}{|c|c|c|c|}
\hline Nome do Professor & Departamento & Data da Entrevista & Número \\
\hline $\begin{array}{l}\text { Prof. }^{\text {a }} \text { Dra. Janice } \\
\text { Theodoro da Silva }\end{array}$ & História & 09.08 .2011 & 1 \\
\hline $\begin{array}{l}\text { Prof. Dr. Luis Angel } \\
\text { Coggiola }\end{array}$ & História & 30.09 .2011 & 2 \\
\hline $\begin{array}{l}\text { Prof. }^{\text {a }} \text { Dra. Zilda M. } \\
\text { Grícoli Iokoi }\end{array}$ & História & 07.10 .2011 & 3 \\
\hline $\begin{array}{l}\text { Prof. a Dra. Sandra G. } \\
\text { Teixeira Vasconcelos }\end{array}$ & Letras Modernas & 24.11 .2011 & 4 \\
\hline $\begin{array}{l}\text { Prof. }^{\text {a }} \text { Dra. Eunice R. } \\
\text { Durham }\end{array}$ & Antropologia & 24.11 .2011 & 5 \\
\hline $\begin{array}{l}\text { Prof. Dr. José Álvaro } \\
\text { Moisés }\end{array}$ & Ciência Política & 29.03 .2012 & 6 \\
\hline $\begin{array}{l}\text { Prof. Dr. Davi } \\
\text { Arrigucci Júnior }\end{array}$ & $\begin{array}{l}\text { Teoria Literária e } \\
\text { Literatura Comparada }\end{array}$ & 25.05 .2012 & 7 \\
\hline $\begin{array}{l}\text { Prof. Dr. Francisco M. } \\
\text { C. de Oliveira }\end{array}$ & Sociologia & 04.07 .2012 & 8 \\
\hline $\begin{array}{l}\text { Prof. }^{\text {a }} \quad \text { Dra. Leyla } \\
\text { Perrone-Moisés }\end{array}$ & Letras Modernas & 25.07 .2012 & 9 \\
\hline $\begin{array}{l}\text { Prof. }^{\text {a }} \text { Dra. Olgária } \\
\text { Feres Chain Matos }\end{array}$ & Filosofia & 26.07 .2012 & 10 \\
\hline $\begin{array}{l}\text { Prof. Dr. Renato } \\
\text { Janine Ribeiro }\end{array}$ & Filosofia & 29.08 .2012 & 11 \\
\hline $\begin{array}{l}\text { Prof. Dr. Mario } \\
\text { Miguel González }\end{array}$ & Letras Modernas & 29.08 .2012 & 12 \\
\hline $\begin{array}{l}\text { Prof. Dr. José Augusto } \\
\text { Guilhon Albuquerque }\end{array}$ & Ciência Política & 03.09 .12 & 13 \\
\hline $\begin{array}{lll}\text { Prof. }^{\text {a }} & \text { Dra. } & \text { Sandra } \\
\text { Nitrini } & & \end{array}$ & $\begin{array}{l}\text { Teoria Literária e } \\
\text { Literatura Comparada }\end{array}$ & 12.09 .2012 & 14 \\
\hline $\begin{array}{l}\text { Prof. Dr. Benjamin } \\
\text { Abdala Jr. }\end{array}$ & $\begin{array}{l}\text { Letras Clássicas e } \\
\text { Vernáculas }\end{array}$ & 03.10 .12 & 15 \\
\hline $\begin{array}{lll}\text { Prof. } & \text { Dr. } & \text { Franklin }\end{array}$ & Filosofia & 24.10 .12 & 16 \\
\hline
\end{tabular}




\begin{tabular}{|l|l|l|l|}
\hline Leopoldo e Silva & & & \\
\hline $\begin{array}{l}\text { Prof. Dr. Wanderley } \\
\text { Messias da Costa }\end{array}$ & Geografia & 13.03 .13 & 17 \\
\hline $\begin{array}{l}\text { Prof. Dr. Sérgio } \\
\text { Adorno }\end{array}$ & Sociologia & 30.04 .13 & 18 \\
\hline $\begin{array}{l}\text { Prof. }{ }^{a} \text { Dra. Ana Fani } \\
\text { Alessandri Carlos }\end{array}$ & Geografia & 03.06 .13 & 19 \\
\hline
\end{tabular}

\section{A história oral de vida acadêmica}

As concepções de história oral que embasam esta pesquisa se inserem no terreno da "história viva", concebida como história aberta na formulação teórica construída por Walter Benjamin em Teses Sobre o Conceito de História ${ }^{6}$. São as críticas elaboradas por este autor em relação à escola metódica que instruíram, desde o princípio, a realização do projeto de pesquisa a respeito das trajetórias de vida acadêmica de docentes da Faculdade de Filosofia Letras e Ciências Humanas da USP, que resultou no presente trabalho. Isso significa dizer que para além dos documentos e dados oficiais a respeito das atividades acadêmicas, rankings e congêneres, objetivou-se compreender os aspectos subjetivos e políticos que envolvem o conjunto dessas trajetórias. Características, na maior parte das vezes, subliminares aos currículos sistematizados e à carreira docente formal.

A história do tempo presente é viva e aberta quando permite uma avaliação crítica do passado, a apreciação e/ ou a formulação de novos documentos, além da averiguação de perspectivas oficiais em comparação com as marginais. No entanto, nem toda proposta de história oral e, nem toda História do Tempo Presente, estão preocupadas com uma avaliação questionadora ou aberta em relação ao passado ${ }^{7}$. Fontes orais podem ser utilizadas de maneiras diferentes, inclusive, tradicionalmente vinculadas a modelos convenientes à escola metódica. Além disso, pesquisas nas mais variadas áreas de conhecimento comumente utilizam entrevistas trabalhadas enquanto um recurso técnico

\footnotetext{
${ }^{6}$ Ver: BENJAMIN, W. Magia e técnica, arte e política. Ensaios sobre literatura e história da cultura. São Paulo: Brasiliense, 1987, p. 222-232.

${ }^{7}$ Ver: MEIHY, J. C. S. B. (Re) Introduzindo a história oral no Brasil. São Paulo: Xamã, 1996.
} 
e de apoio a projetos que necessitam de levantamentos objetivos e imediatos. Nem toda entrevista precisa fazer parte de um projeto de história oral ou deseja sê-lo.

A proposta de história oral a qual essa pesquisa está filiada diferencia-se na medida em que compartilha pressupostos metodológicos que valorizam o trabalho de transposição da oralidade para a escrita através da colaboração dos entrevistados. Quando o objetivo da investigação é conhecer os critérios e os delineamentos construídos pela memória coletiva, as experiências compartilhadas falam mais alto e qualificam a comunidade de destino. Através da análise de questões subjetivas, as declarações em uma entrevista de história oral de vida podem ser imprecisas, produzir mitos e "mentiras". Afinal, o documento construído a partir de lembranças reelaboradas é mediado permanentemente pela reconstrução do passado no tempo presente. As fontes escritas construídas a partir das entrevistas podem transpor os limites das "versões oficiais" e tornarem-se ricos mananciais repletos de possibilidades analíticas e aspectos pouco apresentados pelos dados factuais:

\begin{abstract}
Alguns praticantes da história oral, na ânsia de corrigir preconceitos e fabulações, deixaram de considerar as razões que levaram os indivíduos a construir suas memórias de determinada maneira, e não perceberam como o processo de relembrar poderia ser um meio de explorar os significados subjetivos da experiência vivida e a natureza da memória coletiva e individual. (...) Eles não se deram conta de que as "distorções" da memória podiam ser um recurso, além de um problema ${ }^{8}$.
\end{abstract}

"A memória não possui fio de Ariadne" lembra Olgária Matos, uma das entrevistadas, o que significa que ela se encontra diante de um labirinto que compartilha incertezas e, ao mesmo tempo, ricas possibilidades. ${ }^{9}$ A história oral de vida, contudo, ao se preocupar com a memória coletiva presente nos relatos individualmente produzidos pelos narradores e, portanto, com as disputas e negociações internas ao grupo, permite compreender como a comunidade de destino orienta suas lembranças e organiza as experiências que tiveram em comum. Trabalhar com histórias de vida, dessa maneira, significa problematizar como os eventos foram lembrados e resignificados, ou seja, como e porquê os mesmos foram organizados pelos colaboradores no tempo presente.

\footnotetext{
${ }^{8}$ Alistair Thomson, Michael Frisch e Paula Hamilton. "Os debates sobre memória e história: alguns aspectos internacionais". In: FERREIRA, M. de M. \& AMADO, J. Usos e Abusos da História Oral. Rio de Janeiro: FGV, 1996, p.67.

${ }^{9}$ MATOS, O. F. C. Memória e História. A Terceira Idade (SESC-São Paulo), São Paulo, Ano 4, n 6 , out. 1992, p.10.
} 
A entrevista de história oral de vida é o resultado final de um processo de colaboração entre entrevistador e entrevistado, por isso este é chamado de colaborador. ${ }^{10}$ A entrevista escrita aprovada pelo colaborador é o resultado das memórias individuais organizadas e mediadas pela memória coletiva. Isso significa, segundo Michael Pollak, que a organização das memórias individuais é fruto de um processo de disputa e negociação com a memória coletiva. ${ }^{11}$ Pollak, por sua vez, instruiu suas pesquisas a partir dos estudos de Maurice Halbwachs a respeito das relações entre a memória individual e o limite delineado pela memória coletiva. Halbwachs já havia demonstrado em A memória coletiva como a memória individual está enraizada em determinadas relações sociais e laços de solidariedade com grupos ou comunidades mais amplas, e é um fenômeno construído que depende do contexto no qual ela é articulada e, portanto, da relação conflituosa estabelecida com os outros no contexto em que opera:

Não é suficiente reconstituir peça por peça a imagem de um acontecimento do passado para se obter uma lembrança. É necessário que essa reconstrução se opere a partir de dados ou de noções que se encontram tanto no nosso espírito quanto no dos outros, porque elas passam incessantemente desses para aquele e reciprocamente, o que só é possível se fizeram e continuam a fazer parte de uma mesma sociedade. Somente assim podemos compreender que uma lembrança possa ser ao mesmo tempo reconhecida e reconstruída ${ }^{12}$.

É por isso que, em seu conjunto, as entrevistas de história oral de vida possibilitam compreender como a comunidade de destino orienta suas lembranças e organiza as experiências que tiveram em comum. Ao se perscrutar os labirintos das memórias individuais percorridos por cada professor, a intenção principal é compreender o complexo rizoma que alimenta as trajetórias da comunidade docente, quais as principais referências, disputas, acordos e seus porquês. Sem o fio de Ariadne, cabe seguir as indicações, as sugestões e os passos percorridos pelos docentes para se entender as dinâmicas internas da vida acadêmica; os traços mais fortes da experiência coletiva.

\footnotetext{
${ }^{10}$ MEIHY, J. C. S. B. Manual de História Oral. Op. cit., p.124.

${ }^{11}$ POLLAK, M. "Memória e identidade social". Estudos Históricos, Rio de Janeiro, vol. 5, n. 10, 1999, pp.205-206.

${ }^{12}$ HALBWACHS, M. A memória coletiva. São Paulo: Vértice, 1990, p.34.
} 
Dentre as possibilidades de abordagem metodológica em entrevistas de história oral, optou-se pelo gênero da história oral de vida ${ }^{13}$. Um projeto organizado a partir de histórias de vida acadêmica permitiu compreender também os sentidos particulares de cada trajetória e, principalmente, como, quando e onde os caminhos individuais se cruzam e se imbricam uns aos outros. Não obstante, a produção de fontes baseadas em histórias orais de vida, implica compreendê-las em suas diferentes temporalidades. $\mathrm{Ou}$ seja, não se pode ignorar o fato de que o passado revelado através das lembranças sofre diretamente a interferência de fatores impostos pelo tempo presente. Isso significa dizer que a narrativa elaborada no presente procura dar um sentido à trajetória e ao conjunto da experiência ex post. Cabe ao oralista estar atento ao processo de produção dessas memórias, desse conhecimento coletivo. Interessa justamente a forma subjetiva como a experiência é revelada e reorganizada e, ainda, em função de quais razões a história individual foi reelaborada no tempo presente e o que essa reconstrução tem a nos dizer:

As pessoas vivem suas vidas e formulam uma percepção de si mesmas que pode ou não corresponder com a nossa percepção delas. A história oral pode ou não refletir essas duas visões. Em alguns casos nossos informantes distorcem seriamente, em outros nós distorcemos, não porque nós mentimos ou eles mentem, mas porque ambos sabemos que a forma como o passado é visto tem consequências para a forma como o presente é estruturado, e porque nós temos diferentes pontos de referencia para nossa apresentação de nós mesmos. Portanto, o que decidimos discutir e a maneira pela qual é discutida, a seleção, observação e interpretação dos eventos do passado são feitas dentro do contexto de como nós vivemos nossa própria história e o significado que atribuímos a essa história. De algumas formas nossos documentos são ricos em excesso. Eles nos dizem sobre o que aconteceu, mas também nos dizem o que as pessoas acham que aconteceu e como elas internalizaram e interpretaram o que aconteceu. Eles nos contam como personalidades e forças sociais reconstroem a memória para avançar ou obstruir o desenvolvimento ou formas particulares de ver o passado $^{14}$.

\footnotetext{
${ }^{13}$ As entrevistas de história oral de vida permitiram visualizar com amplitude as carreiras docentes e o exercício de sua atividade intelectual a partir da universidade pública. O trabalho com histórias de vida significa que nossa preocupação esteve voltada para a compreensão e a avaliação dos eventos narrados e como os mesmos foram organizados pelos colaboradores. Ou seja, o conjunto das histórias de vida permite conhecer detalhes a respeito do modo como a comunidade de destino orienta suas lembranças e organiza as experiências que tiveram em comum.

14 "People live their lives and formulate a perception of themselves which may or may not correspond to our perception of them. The oral history may or may not reflect either of these views. In some cases our informants seriously distort, in some case we do, not because we or they lie, but because both of us know that the way the past is viewed has consequences for the way the present is structured, and because we have different reference points for our presentations of ourselves. Thus, what we decide to discuss and the manner in which it is discussed, the selection, observation and interpretation of the events of the past, is done within the context of how we have lived our own history and the meaning we have attached to that
} 
As memórias individuais tangenciadas, atingidas pela situação imposta pelas entrevistas de história oral, foram analisadas enquanto parte de uma memória coletiva. Sendo assim, as memórias individuais somente interessaram à pesquisa enquanto parte de um conjunto de experiências vividas pelo grupo, pela comunidade de destino: os professores titulares. O que definiu o grupo de docentes a ser investigado foi o fato de terem compartilhado uma trajetória em comum enquanto professores da USP, mais especificamente, da FFLCH-USP, em um determinado contexto histórico (econômico, político, cultural, acadêmico). E, mais, trata-se de uma comunidade que vivenciou passagens específicas da carreira acadêmica e composta por professores que palmilharam todas as suas etapas, muitas vezes, tendo iniciado o percurso como instrutores de ensino e percorrido todo um caminho até alcançarem a titularidade mediante a realização de vários concursos públicos.

As entrevistas de história oral de vida necessitam de cuidados especiais por serem constituídas em narrativas baseadas nas interseções entre memória individual e coletiva. Isso significa que o oralista deve estar atento às especificidades da fonte que ele próprio produz:

Fontes orais são confiáveis, mas com uma credibilidade diferente. A importância do testemunho oral é que este pode mentir não com relação à aderência ao fato, mas na distância em relação a ele, conforme a imaginação, o simbolismo e o desejo emergem. Portanto, não existem fontes orais "falsas". Uma vez que tenhamos conferido sua credibilidade factual com todo o critério de crítica filosófica e verificação factual estabelecidas, que são exigidas por todos os tipos de fontes de qualquer forma, a diversidade da história oral subsiste, como o fato de que "falsas" declarações são ainda psicologicamente 'verdadeiras', e que essa verdade pode ser tão importante quanto os registros factualmente confiáveis ${ }^{15}$.

history. In some ways our documents are too rich. They tell us of what happened but they also tell us what people thought happened and how they have internalized and interpreted what happened. They tell us how individual personalities and social forces reconstruct memory to advance or hinder the development or particular ways of viewing the past". GRELE, R. J. Envelops of sound: the art of oral history. Westport, Connecticut: Praeger, 1991, pp.244-245.

15 "Oral sources are credible but with a different credibility. The importance of oral testimony may lie not in its adherence to fact, but rather in its departure from it, as imagination, symbolism, and desire emerge. Therefore, there are no 'false' oral sources. Once we have checked their factual credibility with all the established criteria of filosophical criticism and factual verification which are required by all types of sources anyway, the diversit of oral history consists and the fact that 'wrong' statements are still psicologically 'true', and that this truth may be equally as important as factually reliable accounts". PORTELLI, A. The death of Luigi Trastulli and other stories - form and meaning in oral history. New York: State University of New York Press, 1991, p. 51. 
Em termos benjaminianos, as lembranças trazidas à tona pelas entrevistas de história oral de vida acadêmica são como fagulhas que, ao atearem fogo no passado, reconstroem-no no presente. Nesse sentido, as narrativas precisam ser entendidas como parte de um exercício de reconstrução instruída do passado e em diálogo com o tempo do agora. No caso dos docentes, existe um poderoso agravante. A própria carreira docente na Universidade de São Paulo exige que os professores apresentem memoriais capazes de dar conta de suas trajetórias a cada nova empreitada acadêmica. $\mathrm{O}$ ato de rememorar, reconstruir as lembranças, é, dessa maneira, um exercício já bem conhecido por parte dos docentes. Esse fato sugeriu a utilização dos memoriais entregues no ato da "titulatura" como documentos passíveis de análise. Nesse sentido, eles foram utilizados na elaboração das entrevistas e, algumas vezes, contribuíram enquanto documentos biográficos para a análise das trajetórias docentes.

A proposta teórica de história oral a que esse projeto se filia é parte de um conjunto de renovações introduzidas pela Nova História Social e Cultural responsável pela incorporação de novos objetos e problemas ao campo dos estudos históricos. A perspectiva da história oral de vida permite articular micro e macro-história, e pensar as trajetórias individuais e suas relações com o coletivo, contribuindo para a construção de uma história capaz de reunir as contribuições da nova história cultural, da antropologia e da sociologia. Como defende Luiza Passerini, o oralista deve estar atento às dimensões da micro e da macro-história, pois "quando tais discussões são ignoradas, como ocorre com frequência na historiografia política contemporânea, o resultado é uma espécie de efeito ótico deformador que, multiplicando-se as particularidades, torna mais difícil a compreensão de algumas linhas do todo" ${ }^{\prime 16}$.

Para Luiza Passerini, pensar a intersubjetividade significa compreender quais foram as experiências vivenciadas e divididas pelo conjunto da comunidade que se está estudando. Uma colônia de destino compartilha intersubjetividades, portanto, decisões que são baseadas em determinadas influências culturais, econômicas, políticas, acadêmicas, de classe social e de gênero. No caso específico analisado por esta tese, os docentes em questão compartilharam experiências universitárias em um contexto político e, especificamente, ditatorial, que marcou profundamente a Universidade de São Paulo, com grande impacto sobre a Faculdade de Filosofia. É preciso frisar que a experiência acadêmica compartilhada pelos docentes ao longo da ditadura, bem como,

\footnotetext{
${ }^{16}$ PASSERINI, L. A memória entre política e emoção. São Paulo: Letra e Voz, 2011, p. 27.
} 
as situações impostas durante o período de transição para a democracia política, foram responsáveis por imprimir traços muito característicos à vida intelectual desse grupo.

As trajetórias de nossos colaboradores foram marcadas por um contexto político ditatorial e, ao mesmo tempo, pelo posterior processo de redemocratização. Internamente, os professores conviveram com mudanças profundas ocorridas na Faculdade de Filosofia da USP e, nas universidades públicas como um todo, atreladas a um processo de profissionalização da vida docente. Trata-se, portanto, de uma comunidade abalizada por traços históricos e características que envolvem a transição política trançada do país e, concomitantemente, o lento processo de profissionalização da carreira acadêmica. Essas referências não somente delimitam nossa comunidade de destino, como foram responsáveis por orientar toda a investigação.

Questões éticas nortearam os trabalhos do início ao fim. O fato de serem pessoas públicas e intelectuais renomados não implicou em cuidados para além daqueles já publicamente adotados pelo Núcleo de Estudos em História Oral (NEHO-USP). Desde o primeiro momento da entrevista os professores foram esclarecidos quanto ao objetivo da pesquisa e, principalmente, em relação a sua plena participação na elaboração do texto final. As primeiras conferências textuais realizadas indicaram claramente que o grupo assumiria a responsabilidade pela revisão formal, eliminando da escrita a maioria dos traços informais presentes na oralidade e, muitas vezes, acrescentando notas explicativas. Nesse sentido, o formato "acadêmico" que algumas entrevistas assumiram, deve-se à preocupação de orientar o leitor quanto a nomes, instituições e eventos internos à Universidade de São Paulo, de modo a instruir a leitura do grande público. O resultado foi um trabalho de colaboração (co-labor-ação) que envolveu muita negociação e longos períodos de espera pela aprovação final do texto autorizado.

\section{Introdução às histórias de vida dos colaboradores.}

Tenho uma origem parecida e nunca me vi, intelectualmente, menosprezado por isso, por Florestan e seu grupo. A Faculdade de Filosofia era historicamente um lugar de encontro mannheimiano de intelectuais de origens diversas e desencontradas. Claude LéviStrauss, em Tristes Trópicos, já havia notado o quanto a Faculdade, de que fora um dos fundadores, quebrava linhas de separação social 
arraigada na sociedade paulistana. Ela abria democraticamente o acesso à Universidade a populações que, sem a escola pública, teriam ficado fora dela, como era o caso de Florestan, de Luiz (Pereira) e o meu próprio ${ }^{17}$.

Todos os docentes que contribuíram com essa pesquisa possuem uma grande familiaridade em conceder entrevistas. Soma-se a isso, o fato de serem experientes na tarefa de explicar suas próprias trajetórias, já que em vários episódios da carreira, memoriais acadêmicos tiveram que ser redigidos e apresentados a seus pares. Trata-se de um grupo, portanto, acostumado a prestar contas ao Estado e à sociedade de todos os passos acadêmicos dados ao longo de sua carreira universitária. Tamanha exposição pode explicar o cuidado existente em relação à apresentação de questões de ordem pessoal, íntima e familiar.

Tanto nos memoriais de "titulatura" elaborados pelos docentes pesquisados, quanto nas entrevistas concedidas, a origem social e familiar, bem como a vida pessoal, infância e adolescência, até o ingresso na universidade e/ou na carreira acadêmica, foram tratadas através de descrições circunscritas e objetivas. Afinal, qual o motivo do silenciamento em relação às histórias pessoais? Dentre as hipóteses examinadas, considerou-se que esses interditos podem estar ligados a uma atitude que evoca a autopreservação, a construção de uma fronteira que tem o intuito de proteger a sua intimidade e a da sua família. Outra hipótese estudada, disse respeito à maneira especial como os docentes organizaram as narrativas e procuraram explicar a trajetória de vida a partir da entrada na carreira universitária. Em geral, o ingresso como docente da Faculdade de Filosofia da USP apresentou-se como uma importante linha mestra que orienta as memórias individuais, delineia e confere identidade coletiva ao grupo estudado.

Nesse sentido, durante as entrevistas de histórias de vida, os colaboradores se restringiram em contar, essencialmente, suas histórias de vida acadêmica. Na maioria das vezes, os períodos vividos circunscritos à infância e à adolescência foram expostos, stricto senso, por meio da formação escolar adquirida. $\mathrm{O}$ fato das entrevistas terem sido concedidas para um doutorando, portanto, visando à elaboração de uma tese, cujas entrevistas seriam mais uma vez avaliadas pela universidade, pode ter conferido, de antemão, um enquadramento acadêmico para a organização das narrativas. Além disso,

\footnotetext{
${ }^{17}$ MARTINS, J. de S.. A sociologia como aventura - memórias. São Paulo: Contexto, 2013, p.153.
} 
muitos professores optaram por conceder a entrevista na própria universidade no intervalo de suas atividades docentes. Isso significa dizer que algumas entrevistas foram realizadas numa fração de tempo restrita e em meio a atividades acadêmicas cotidianas. Ou seja, para alguns colaboradores, entrevistas em geral fazem parte integrante de suas atividades acadêmicas e, portanto, são encaradas sempre com profissionalismo e objetividade.

\section{Os colaboradores}

Por que investigar apenas a Universidade de São Paulo? Por que a pesquisa se restringiu à Faculdade de Filosofia, Letras e Ciências Humanas da USP? O objetivo não foi diferenciar a USP de outras instituições, mas estudá-la enquanto parte integrante de um problema maior que é o da universidade pública no país. A opção pela escolha dos docentes pertencentes a FFLCH-USP como comunidade de destino se justificou pela formação de quadros responsáveis pela implantação e desenvolvimento de institutos, faculdades, graduações e pós-graduações por todo o país. Não se trata, contudo, de uma proposta comemorativa, mas preocupada com as contradições que envolveram a crise de um modelo de universidade e a institucionalização de uma nova carreira docente.

Investigar especificamente a trajetória de vida acadêmica dos professores titulares da FFLCH-USP explica-se não só pelo fato desses intelectuais serem conhecedores de todos os estágios da vida acadêmica em sua integralidade, mas primordialmente por serem professores integrados a um plano de carreira no interior de uma instituição pública.

A seguir, serão apresentadas as origens sociais e a vivência escolar dos colaboradores entrevistados, bem como as principais pesquisas desenvolvidas após o ingresso como professores na Universidade de São Paulo. A formação intelectual foi o principal critério utilizado na elaboração dos resumos, dada a importância que o ensino público e gratuito e a possibilidade de acesso ao conhecimento formal e clássico teve para a construção das carreiras docentes investigadas:

Eunice Ribeiro Durham (Durham) nasceu em Limeira-SP em 1932. Seu pai, originário de Descalvado-SP, foi professor catedrático e diretor da Faculdade de 
Educação da USP. Durham iniciou seus estudos na escola pública Caetano de Campos, mas concluiu o ensino primário e o antigo colegial no Colégio Rio Branco graças a uma bolsa de estudos: "O Colégio Rio Branco era particular e meu pai, obviamente, não tinha dinheiro para pagar um colégio caro. Quando o proprietário, Sampaio Dória, vendeu o colégio, os professores fizeram um movimento e, com a ajuda do Antônio Ermírio de Moraes e do Rotary Club, encamparam a escola", comentou a professora. Fez graduação em Ciências Sociais na Faculdade de Filosofia da USP entre 1951 e 1954: "Quando cheguei na Faculdade de Filosofia o ambiente era totalmente diferente. Havia muita politização, que não existia no Rio Branco. Mas, como ambiente, não era nada divertido. O primeiro ano foi muito difícil, quase fui reprovada em Sociologia". Ao concluir o curso de Ciências Sociais, Durham foi convidada pelo Prof. Egon Schaden, catedrático responsável pela cadeira de Antropologia, para ser sua assistente: "Naquele tempo era comum ser assistente-voluntário, o que significava que não recebíamos salário. Arrumávamos um emprego paralelo. Os assistentes voluntários organizavam os seminários e auxiliavam o professor, esperando abrir uma vaga”. Além das aulas que ficavam a cargo dos assistentes na ausência do catedrático, nessa época, a Revista de Antropologia fundada por Egon Schaden em 1953 demandava a produção de muitas resenhas. Entre uma pesquisa e outra, Durham foi convidada pelo Prof. Emílio Willems, fundador da cadeira de Antropologia da Faculdade de Filosofia, para realizar o mestrado na Vanderbilt University, em Nashville. Durham acabou concluindo seu mestrado sobre a imigração italiana em Descalvado - cidade na qual viviam seus avós maternos de origem italiana - foi realizado na USP onde também defendeu o doutorado sobre a migração rural para a cidade que, mais tarde, daria origem ao livro $A$ caminho da cidade. A vida rural e a migração para São Paulo. Tornando-se assistente-doutor, Durham deu continuidade à carreira docente e defendeu a livre-docência sobre a obra etnográfica de Bronislaw Malinowski em 1973. A “titulatura” foi obtida em 1985.

Francisco Maria Cavalcanti de Oliveira (Oliveira) nasceu em Recife no ano de 1933. Em entrevista contou que sua família, que pertencia à classe média, era composta por onze irmãos: “O meu pai era farmacêutico prático, não era diplomado e, minha mãe, era dona de casa. Crescemos todos no Recife em uma família muito feliz. As minhas recordações da infância são sempre muito gratas". Oliveira estudou os primeiros anos em um grupo escolar do estado e realizou o ginásio e o secundário no Colégio Salesiano. Em 1956 concluiu o bacharelado em Ciências Sociais pela Universidade do 
Recife, atual Universidade Federal de Pernambuco. Trabalhou no Banco do Nordeste e, posteriormente, na equipe liderada por Celso Furtado, na Superintendência de Desenvolvimento do Nordeste (SUDENE) entre 1959 e 1964. Afastado de suas atividades pelo golpe de 64, Oliveira passou a trabalhar prestando consultorias em São Paulo-SP. Em 1970 foi convidado pelo Prof. Otávio Ianni, que dirigia o Centro Brasileiro de Análise e Planejamento (CEBRAP), para trabalhar na equipe que estudava planejamento regional. Trabalhou no CEBRAP durante 25 anos, encerrando sua participação devido a desentendimentos políticos em 1995. Iniciou suas atividades como professor universitário ministrando aulas de economia no curso de pós-graduação em Economia da Pontifícia Universidade Católica de São Paulo em 1980. Atuou nessa instituição até 1988, quando a convite da Prof. ${ }^{a}$ Dra. Irene Cardoso e da Prof. ${ }^{a}$ Dra. Eva Blay, foi integrado ao corpo docente do Departamento de Sociologia da FFLCH-USP. Oliveira obteve o título de notório saber concedido pela Congregação da FFLCH-USP em 1992, que equivale institucionalmente ao doutorado e, no mesmo ano, defendeu a “titulatura". Aposentado desde 1998, Oliveira ainda orienta alunos na pós-graduação e desenvolve pesquisas junto ao Centro de Estudos dos Direitos da Cidadania (CENEDIC).

Leyla Perrone-Moisés (Perrone-Moisés) nasceu em 1936 em São Paulo, mas passou a infância em Passa Quatro-MG. Sua família era composta por comerciantes italianos que negociavam fumo em corda. Aos onze anos voltou a São Paulo com o propósito de estudar, tendo cursado o ensino primário e secundário no Colégio Sion como semi-interna. Aos 16 anos de idade ingressou no ateliê do pintor Samson Flexor, a dedicação à pintura rendeu-lhe a participação e o reconhecimento de suas obras em Bienais de Arte. Em 1954 cursou o primeiro ano do curso de Letras no Mackenzie, mas por influência do seu irmão que fazia Química na USP, acabou se transferindo no segundo ano para a Faculdade de Filosofia da mesma instituição, onde segundo suas lembranças "o ambiente era muito mais inserido na vida social real de São Paulo do que o ambiente que eu conhecia do Colégio Sion e da Faculdade Mackenzie”. Paralelamente à faculdade, cursou francês na Aliança Francesa, tendo completado todo o período de formação. Ao concluir a graduação em Letras Neolatinas, afastou-se momentaneamente da universidade para cuidar das filhas pequenas e, em seguida, trabalhou para o Suplemento Literário do jornal O Estado de São Paulo (OESP) e como professora no ensino médio e universitário. Na Pontifícia Universidade Católica de São Paulo 
ministrou aulas de Literatura Francesa entre 1963 e 1975 e contribuiu na criação de uma pós-graduação em Teoria Literária. Em 1970, foi chamada pelo Prof. Albert Audubert para ministrar aulas na Faculdade de Filosofia. Audubert era o catedrático responsável pela cadeira de Francês e apreciava os artigos que Perrone-Moisés escrevia no OESP: "fui contratada por alguém que nunca tinha me visto, mas que lia meus artigos no Suplemento. Ele me ligou e disse que sabia que eu tinha me formado na Maria Antônia, e que o meu lugar era lá”. Em uma fase em que a contratação de novos professores dependia da decisão do catedrático, Perrone-Moisés sempre fez questão de ressaltar que Audubert havia adotado um critério técnico e puramente intelectual. Começou a trabalhar na Faculdade de Filosofia como assistente voluntária e, em 1971, defendeu o doutorado sobre o Conde de Lautréamont, pseudônimo literário de um poeta uruguaio que viveu na França, sob a orientação de Audubert. Em 1975, defendeu a livre-docência intitulada A crítica-escritura, um discurso dúplice, que em 1978, seria publicada pela Ática com o título Texto, crítica, escritura. Segundo a autora, "Barthes era, ao mesmo tempo, tema e inspirador teórico" desta tese que foi desenvolvida na França com uma bolsa da Fundação de Amparo à Pesquisa do Estado de São Paulo (FAPESP). Defendeu a "titulatura" em 1986 e foi aclamada professora emérita pela FFLCH-USP em 1996. Aposentou-se em 1987, mas trabalha na orientação de teses e dissertações até o momento.

Mário Miguel González (González) (1938-2013) nasceu em Alta Gracia, a trinta quilômetros da cidade de Córdoba na Argentina. Sobre suas origens, González contou: "Minha mãe era cordobesa, de uma família que vivia ali há muitíssimos anos. Já o meu pai era do outro lado da Argentina, era um imigrante espanhol, veio criança para Buenos Aires, veio com os pais já no século XX fugindo da fome”. Juntamente com a mãe que era professora primária rural, morou e estudou em uma escola isolada na qual "não tinha água, energia elétrica, nada. Nesse lugar só havia essa escola rural que os vizinhos tinham construído. Passei meus primeiros seis anos de vida lá. Aprendi a ler e a escrever porque também não havia mais nada para fazer...”. De volta a Alta Gracia, onde seu pai passou a administrar um hospital, González realizou o secundário e partiu em direção à Córdoba para cursar Letras na Universidade Católica, formando-se em 1964. Logo nos primeiros momentos da graduação, González afirmou ter decidido pela carreira de professor universitário, que o levaria mais tarde a seguir para a Espanha com uma bolsa para realizar o doutorado: "às vezes tive bolsa, às vezes trabalhei como clandestino, 
disfarçado de bolsista na própria instituição que me dava a bolsa. Depois, consegui uma bolsa para ir para Louvain redigir a tese. Mas recebi nesse momento uma notícia triste, meu pai estava doente, estava com câncer”. Devido aos problemas de saúde do pai, González voltou para a Argentina em 1967 sem concluir o doutorado. Depois da morte do pai, não havia muitas perspectivas profissionais para continuar na Argentina. Graças ao contato que manteve com professores da USP que estudaram na Espanha, acabou recebendo um convite do Prof. Julio García Morejón, que queria um hispanista para trabalhar no curso de línguas da recém-criada Escola de Comunicações Culturais, hoje Escola de Comunicação e Artes (ECA-USP). Chegou a USP no início de 1968 e, uma vez em contato com o catedrático responsável pela cadeira de Espanhol, acabou sendo contratado também pela Faculdade de Filosofia: "Quando ele descobriu que minha área era literatura espanhola, ele me trouxe para a Faculdade de Filosofia também. E acabei tendo dois contratos, um com cada instituição. Nessa época lecionava língua espanhola na ECA e literatura espanhola na Maria Antônia”. A partir da criação do Departamento de Letras Modernas atuou em várias frentes como auxiliar de ensino e, orientado por Morejón, defendeu o doutorado em 1973 com uma tese intitulada El conflicto dramático en Bodas de sangre de Federico García Lorca. Defendeu a livre-docência em 1993 com a tese A saga do anti-herói - Estudo sobre o romance picaresco espanhol e algumas das suas correspondências na literatura brasileira. Depois de anos de dedicação à docência, orientação e administração na Faculdade de Filosofia, González obteve a “titulatura" em 1996. Mesmo aposentado desde 2007, trabalhou orientando alunos na pós-graduação até o seu falecimento em 15 de fevereiro de 2013.

José Augusto Guilhon de Albuquerque (Albuquerque) nasceu em Belém-PA em 1940. Na entrevista Albuquerque apresentou-se como membro de uma família de funcionários públicos que fez parte da elite burocrática paraense. Seu pai, agrônomo e funcionário público federal, foi transferido para o Rio de Janeiro, onde realizou uma parte do primário em escola de padres e, outra, em uma escola de classe média também católica. Cursou o secundário no Colégio Pedro Segundo e foi fazer filosofia na Faculdade Nacional de Filosofia da Universidade do Brasil, graduando-se em 1962. Com uma bolsa de estudos foi para Louvain (Bélgica) realizar o mestrado entre 1963 e 1969. Dando sequência aos estudos, foi o primeiro pós-graduando em Sociologia a concluir o doutorado naquela universidade em 1972 sob a orientação de Maurice Chaumont: "Foi uma tese na área da Sociologia do Desenvolvimento, baseada em 
pesquisa empírica com estudantes latino-americanos em Louvain. Eu queria entender como era a formação social e política dos estudantes”. De volta ao Brasil, Guilhon Albuquerque ingressou como professor assistente-doutor em 1974 a convite do Prof. Leôncio Martins Rodrigues, com quem tinha trabalhado em Louvain. Defendeu a livredocência em 1977 com a tese Produção e reprodução institucional. Por uma análise política das relações de poder nas instituições: "Tanto nos primeiros artigos que publiquei e, mesmo no trabalho que veio a ser minha tese de livre docência, fui muito influenciado pelo Althusser. Eu publiquei uma tradução do livro Aparelhos Ideológicos de Estado pela Editora Paz e Terra, na qual inseri uma longa apresentação interpretativa", contou o professor. É professor titular desde 1985, tendo se aposentado em 2005. Atualmente é membro do Grupo de Estudos Brasil-China do Centro de Estudos Avançados da Unicamp.

Davi Arrigucci Júnior (Arrigucci Jr.) nasceu em São João da Boa Vista, interior do estado de São Paulo, em 1943. Descendente de italianos por parte do pai, que exerceu a medicina e, de antigos moradores da região, por parte de mãe, Arrigucci afirma: "Nasci e fui criado em São João. Cursei o grupo escolar Cel. Joaquim José e depois fiz o ginásio, o velho ginásio de São João, 'Cristiano Osório de Oliveira', que já não existe mais". Além da formação propiciada pelo curso científico e por professores como Francisco Paschoal de língua portuguesa, Arrigucci estudou latim em período contrário à escola com o Prof. Américo Casellato: "Eu ia para a casa do Casellato para manter os estudos de latim, tinha aula particular três ou quatro vezes por semana. Foram elas que me aguçaram o gosto pela tradução". Na fase inicial de sua formação intelectual contou também com uma importante biblioteca pertencente ao Dr. Oliveira Neto: "Digamos que então eu vivi esse ambiente dos livros com os meus pais, com o Oliveira Neto e sua biblioteca. Ali pude ler coisas preciosas como Proust, aos dezessete anos levei para casa aqueles vinte e tantos volumes da Gallimard”. Aos 18 anos foi para São Paulo cursar Letras na Faculdade de Filosofia da USP, onde se graduou. Como de costume na época, Arrigucci foi convidado para iniciar sua carreira como professor assistente por vários catedráticos, podendo escolher entre as áreas de italiano, francês e literatura brasileira, mas acabou optando por ingressar na cadeira de estudos hispanoamericanos, comandada pelo Prof. Julio García Morejón. Depois de alguns desentendimentos, Arrigucci se transferiu para a área de Teoria Literária e Literatura Comparada para trabalhar como assistente de Antônio Cândido de Mello e Souza. Sob a 
orientação deste, defendeu em 1972 sua tese de doutorado sobre a obra do escritor argentino Julio Cortázar intitulada $O$ Escorpião Encalacrado. Em sua carreira como professor no Departamento de Teoria Literária e Literatura Comparada, tornou-se livredocente com uma tese sobre a obra de Bandeira: Humildade, Paixão e Morte: a poesia de Manuel Bandeira. Arrigucci Jr. obteve a "titulatura" em 1992, aposentou-se em 1996 e, em 2011, recebeu o título de professor emérito da FFLCH-USP.

"Nasci em 1943 no interior de São Paulo na cidade de Uchoa, perto de São José do Rio Preto. Vim para São Paulo após concluir o primeiro ano do científico e transferido para o colégio estadual Presidente Roosevelt na extensão do Ipiranga", afirmou o Benjamin Abdala Júnior (Abdala Jr.) em entrevista. Descendente de libaneses, Abdala cursou a graduação em Letras na Faculdade de Filosofia da USP entre 1966 e 1969, período no qual trabalhou paralelamente como jornalista nos Diários Associados. Mais tarde atuou como professor em escolas públicas estaduais e no Cursinho do Grêmio que era organizado pelos estudantes da Maria Antônia. Devido à intensa participação nas lutas de resistência à ditadura civil-militar, foi preso em 1969: “Quando saí da prisão em 1971 eu entrei na pós-graduação. Fui orientado pela professora Maria Aparecida Santilli que trabalhava na época com neorrealismo português". Em 1974 concluiu sua dissertação de mestrado sobre o romancista antisalazarista português Carlos de Oliveira. Ainda sob a orientação da Prof. a Santilli defendeu em 1977 o doutorado que versou sobre um estudo comparado entre as obras de Carlos de Oliveira e Graciliano Ramos, intitulada Representação e participação: $a$ dinâmica do concreto nos romances de Carlos de Oliveira e Graciliano. Começou a carreira como Professor do Departamento de Letras da FFLCH-USP como instrutor voluntário e, em 1977, ingressou como professor da área de Literatura Portuguesa mediante concurso público, não sem antes passar pelo crivo da chamada "Triagem ideológica da USP”. A livre-docência intitulada Imagem ( $\mathrm{n} / \mathrm{a} / \mathrm{c} / \tilde{a} / \mathrm{o})$ política. Literaturas de língua portuguesa, hoje: a dialética do engajamento foi defendida em 1988. É professor titular desde 1992.

José Álvaro Moisés (Moisés) nasceu em 1945 em Campinas-SP. Os avós paternos eram libaneses e do lado materno seu avô era português e a avó brasileira. "Fazendo um background de natureza sócio econômica, do lado da minha mãe, meus tios e, inclusive, duas tias, eram ferroviários. Já pelo lado do meu pai eles se dedicaram ao comércio. Meu pai foi um pequeno comerciante em Campinas", contou Moisés. 
Entre 1952 e 1956 cursou a escola pública primária "Noêmia Asbarhr", depois cursou o então ginásio e quase todo o secundário (clássico) no tradicional "Culto à Ciência” em Campinas. Devido a sua intensa militância estudantil foi obrigado a concluir o secundário no Educandário "Rui Barbosa" no Rio de Janeiro. Ingressou no curso de Ciências Sociais na Faculdade de Filosofia da USP em 1966, tendo se formado em 1970: "Pertenci à Ação Popular até praticamente o segundo ano em que cursava Ciências Sociais na antiga Maria Antônia, Fui coordenador da Ação Popular na Faculdade de Filosofia no ano do meu ingresso que foi 1966", contou o professor. Trabalhou como assistente de pesquisa do Prof. Dr. Francisco Weffort no CEBRAP entre 1970 e 1971. Entre 1971 e 1972 realizou o mestrado na Universidade de Essex, Inglaterra, com a tese The Political participation of the Urban Working-class in Brazil que seria reconhecida pela USP em 1975. Em 1974 ingressou como professor auxiliar de ensino através de concurso realizado na área de Ciência Política do Departamento de Ciências Sociais da FFLCH-USP. Em 1978 concluiu o doutorado com a tese Classes Populares e Protesto Urbano, sob orientação de Weffort. Defendeu a livre-docência em 1994 com a tese Os brasileiros e a democracia e obteve a "titulatura" no ano de 2005. Atualmente é diretor científico do Núcleo de Pesquisas em Políticas Públicas (NUPPs-USP) e coordenador do Grupo de Trabalho sobre a Qualidade da Democracia do Instituto de Estudos Avançados (IEA-USP).

Sandra Margarida Nitrini (Nitrini) nasceu em 1946 e morou no bairro da Luz em São Paulo-SP por trinta anos. "Venho de uma família modesta da classe média. Meu pai era filho de italianos e minha mãe, filha de libanês casado com uma brasileira, por sua vez, filha de uma polonesa com um corso. Como se vê, minha origem tem muita miscigenação", contou a professora. Cursou uma parte do primário no grupo escolar "Prudente de Moraes" e, em seguida, completou os estudos até o clássico no Colégio de Santa Inês. Ingressou em 1965 em Letras Neolatinas na Faculdade de Filosofia da USP. Formada em 1968 em Letras Português e Francês, foi contemplada com uma bolsa do governo Francês para fazer o mestrado na Escola Prática de Altos Estudos de Paris, que foi concluído em 1974 sob a orientação de Algirdas Julien Greimas. “Além da indicação do Prof. Aubert Audubert, contei também com muito apoio da Madame Baudet, professora da Aliança Francesa, onde estudei por sete anos, desde meu primeiro ano do clássico até o último ano de Faculdade", relembra Nitrini. Suas atividades docentes tiveram início nas aulas de latim ministradas no Cursinho do Grêmio da Faculdade de 
Filosofia. Após retornar para o Brasil em 1974, ingressou através de concurso público na Faculdade de Filosofia, Ciências e Letras de Assis, na qual trabalhou com a disciplina de Língua e Literatura Francesa até 1979. Neste ano Nitrini preferiu se desligar das atividades em Assis para assumir uma bolsa de doutorado financiada pela FAPESP. A tese Nove, Novena e o Novo Romance foi concluída em 1984 e orientada pelo Prof. Davi Arrigucci Jr. Em 1981, através de concurso público, passou a fazer parte do quadro docente da Faculdade de Filosofia, primeiramente vinculada ao Departamento de Letras Modernas e, logo depois, ao Departamento de Teoria Literária e Literatura Comparada, no qual realizou a livre-docência em 1996. Nitrini obteve a “titulatura” em 1998 e, entre 2008 e 2012, foi diretora da FFLCH-USP.

Zilda Márcia Grícoli Iokoi (Iokoi) nasceu em 1946 na cidade de São Paulo, na vila Ipojuca. Descendentes de italianos, os familiares de Zilda viviam em cidades do interior, onde passavam por dificuldades financeiras e vieram para a capital durante a Segunda Guerra Mundial a procura de uma vida melhor. Em São Paulo, durante algum tempo, seu pai sustentava uma família de nove pessoas com o emprego de funileiro, primeiro em uma montadora, depois em uma oficina. Fez seus estudos primários em escola pública e, em seguida, cursou o técnico em contabilidade. Depois de interromper os estudos por quatro anos, fez o pré-vestibular coordenado pelo Grêmio Estudantil da Faculdade de Filosofia da USP. Ingressou como aluna de História na mesma instituição em 1969 como aluna excedente, mas foi impedida de fazer o aproveitamento das disciplinas cursadas. Em 1971 realizou novo ingresso para fazer História na FFLCHUSP, onde concluiu a graduação em 1974. Em 1985, também na Faculdade de Filosofia, defendeu o mestrado com a dissertação O Legislativo Paulista na Construção da República, orientada pela Prof. ${ }^{a}$ Dra. Maria de Lourdes Mônaco Janotti. Depois de muitos anos dedicados ao ensino médio como professora em escolas públicas, Zilda prestou concurso para a Disciplina de História do Brasil no Departamento de História da FFLCH-USP em 1986, tendo ingressado como docente no mesmo ano. Na mesma instituição defendeu o doutorado com a tese Igreja e Camponeses: a teologia da libertação e os movimentos sociais no campo, orientada pela Prof. ${ }^{\text {a }}$ Maria Ligia Coelho Prado. Na livre-docência pesquisou a intolerância contra os comunistas judeus no Brasil contemporâneo, trabalho que motivou, em parceria com a Prof. ${ }^{a}$ Dra. Anita Waingort Novinsky, a criação do Laboratório de Estudos sobre a Intolerância (LEI-USP), atual Núcleo de Estudos das Diversidades, Intolerâncias e Conflitos (DIVERSITAS-USP). É 
professora titular da FFLCH-USP desde 2010 e, atualmente, coordenadora do DIVERSITAS-USP.

Franklin Leopoldo e Silva (Leopoldo e Silva) nasceu em São Paulo em 1947. "Minha família materna, no entanto, é toda do sul de Minas Gerais. Meu pai nasceu em Ponta Grossa no Paraná. Fiz meus estudos em colégios religiosos. Estudei no Colégio Salesiano e depois no Colégio Marista, até o ginásio", comentou o professor. Cursou o antigo clássico em escola pública e prestou o vestibular para Filosofia na Faculdade de Filosofia da USP, na qual realizou a graduação entre 1967 e 1971: “A partir de 1968 a Faculdade de Filosofia da Maria Antônia se tornou um foco político, diria até de abrangência nacional. Ela concentrava ali todo um trabalho de irradiação da resistência política". Tornou-se auxiliar de ensino do Departamento de Filosofia em 1972 devido à falta de professores provocada pelas cassações e/ou perseguições empreendidas pela ditadura: "Esse foi então o início da minha carreira. Naquela época não se exigia nenhum título, apenas a graduação. Isso era uma coisa proposital, que o professor fizesse a sua carreira concomitantemente a sua atividade docente". O início de sua carreira docente coincidiu com o começou do mestrado orientado pela Prof. ${ }^{\text {a }}$ Marilena Chauí, que resultaria na dissertação O lugar da psicologia no pensamento de Bergson, concluída em 1975. Realizou o doutorado também sob a orientação de Chauí, que foi defendido em 1981 com o título Imagem e moral do homem na filosofia francesa do final do século XIX e início do século XX. Em 1991, defendeu a livre- docência com a tese Bergson: Intuição e discurso filosófico. É titular da FFLCH-USP desde 1998 e, atualmente, é também professor visitante na Universidade Federal de São Carlos (UFSCAR).

Janice Theodoro da Silva (Theodoro da Silva) nasceu na cidade de São Paulo em 24 de outubro de 1948, mas toda a sua família é originária de Bragança Paulista-SP. “Tive um convívio bem próximo com a cidade de Bragança. As minhas duas avós tiveram sete filhos, portanto eu tinha quatorze tios bragantinos. Voltávamos sempre para Bragança. Penso que sou fruto deste movimento entre o interior e a cidade grande", comenta a professora. Casou-se aos 18 anos e, em 1969, ingressou no curso de História da Faculdade de Filosofia da USP. Depois de concluída a graduação em 1972, defendeu o mestrado em 1975 com a dissertação Raízes da Ideologia do Planejamento orientada pelo Prof. José Sebastião Witter. Segundo Silva, a influência do marxismo era muito forte no contexto em que desenvolveu sua pesquisa: "Escrevi minha dissertação de 
mestrado sobre o Rio Grande do Norte. É uma obra que tem uma marca política clara. Naquela época queria encontrar o que todo mundo procurava, aquilo que era específico do Brasil... Para se fazer a revolução". Iniciou sua carreira docente como professora universitária em 1979 na Unicamp, até que em 1983, quando foram abertas vagas para concurso público no Departamento de História da FFLCH-USP, foi aprovada e ingressou como professora de História da América. Também orientada por Witter defendeu no doutorado a tese São Paulo 1554-1880 - Discurso Ideológico e Organização Espacial. Dando sequência a carreira docente, em 1991 defendeu a livredocência intitulada América Barroca - Tema e variações. Silva obteve a "titulatura" em 1997 e, em 2010, aposentou-se. Atualmente é professora visitante na Universidade Federal da Integração Latino Americana (UNILA).

“Eu nasci em dezembro de 1949. Então venho de uma família de classe média, sem privações, mas que teve que fazer a vida sem a ajuda das respectivas famílias. Não tiveram ajuda nem em termos de imóvel, nem de aluguel, nem nada", comentou em entrevista Renato Janine Ribeiro (Janine Ribeiro). Seu pai, nascido em São PedroSP, veio a se encontrar com sua mãe na cidade de São Paulo quando ambos estavam com 20 anos e se casaram. Janine Ribeiro cursou o ginásio e o clássico no colégio público "Alberto Levi”, onde teve aulas de filosofia com a Prof. ${ }^{a}$ Marilena Chauí e de latim e língua portuguesa com a Prof. ${ }^{a}$ Ana Lia de Almeida Prado. Aos 17 anos ingressou na Faculdade de Filosofia da USP para cursar filosofia em um momento no qual a ditadura tomou medidas repressivas contra a Maria Antônia: "Foi um impacto muito grande. No nosso caso foram cassados, se não me engano, dois professores, Bento Prado e José Arthur Giannotti. Houve outros professores que fugiram, como Ruy Fausto e João Quartim de Morais”, relembra Janine Ribeiro. Concomitantemente à graduação, o Prof. Janine se destacou como aluno na Aliança Francesa e conseguiu uma bolsa para estudar na França, o que impulsionou a sua estadia em Paris entre 1972 e 1975. Durante este período defendeu uma dissertação de mestrado sobre a noção de soberania em Thomas Hobbes na Universidade de Paris I (Pantheon-Sorbonne), sob a orientação de Pierre Burgelin. De volta ao Brasil foi convidado a ingressar como professor no Departamento de Filosofia da USP: "Na época em que ingressei na USP como professor, não havia concurso. Passei por um processo de contratação no qual os departamentos escolhiam os professores. Os concursos não passavam pela cabeça de ninguém”. Já como professor de Ética e Filosofia Política da FFLCH-USP, em 1984 
defendeu o doutorado com o título Ao leitor sem medo - Hobbes escrevendo contra o seu tempo, orientado pelo Prof. Luiz Roberto Salinas Fortes. Em 1991 tornou-se livredocência com a tese Ensaios antigos. Passou a ser professor titular da FFLCH-USP em 1996. Aposentado desde 2011, ainda orienta trabalhos de pós-graduação na mesma instituição.

Olgária Chain Feres Matos (Matos) nasceu em 1950, sua família morava na Vila Clementino em São Paulo-SP. "Meu pai era jornalista e poeta e, minha mãe, pianista. Houve um problema na família e eles empobreceram muito. A situação foi muito difícil na minha infância e adolescência, mas tínhamos as mesmas condições das pessoas de todo o bairro", comentou a entrevistada. Desenvolveu seus estudos primários e secundários no Liceu Paster onde teve aulas com a Prof. ${ }^{a}$ Zelinda Casella, a primeira a inspirar sua paixão pelo conhecimento. Com 17 anos ingressou no curso Filosofia na Maria Antônia em um momento no qual vários professores do curso sofreram com as perseguições da ditadura civil-militar de 64. Concluída a graduação em 1970, seguiu para a França onde fez o mestrado na Universidade de Paris I (Pantheon-Sorbonne), sob a orientação de Pierre Burgelin e intitulado Rousseau: uma arqueologia da desigualdade. "Quando voltei para o Brasil estava com 25 anos e comecei a lecionar no ensino superior, antes de ir à França lecionei no segundo grau. Trabalhei na Escola de Comunicações e Artes (ECA-USP), na Faculdade de Biblioteconomia da USP e na Fundação Getúlio Vargas (FGV-SP)”, comentou Matos. Entre 1975 e 1985 trabalhou na pesquisa de seu doutorado, tendo sido primeiramente orientada por Claude Lefort, na França e, posteriormente, por Marilena Chauí na Universidade de São Paulo. A tese $O s$ Arcanos do inteiramente outro: a Escola da Frankfurt, melancolia, revolução, foi publicada em livro em 1990, ano em que recebeu o Prêmio Jabuti de Ciências Humanas. Começou a dar aulas no Departamento de Filosofia da USP em 1979, mesma casa onde defendeu sua tese de livre-docência sobre Walter Benjamin em 1991. Tornou-se professora titular em 1996 e, se aposentou em 2003. Atualmente é professora visitante na Universidade Federal de São Paulo (UNIFESP) e na Universidade de Sorocaba (UNISO).

Osvaldo Luis Angel Coggiola (Coggiola) nasceu em Buenos Aires no bairro San Fernando em 1950. Cursou uma parte do secundário no Colégio Nacional de Buenos Aires: "Em casa não havia biblioteca, ou seja, eu não tinha esse contato com a cultura. E isso foi um choque bastante forte. Tive que me desvencilhar do catolicismo e, ainda por 
cima, entrar em contato com uma cultura que não tinha", comentou o professor. Ao se mudar com a família para Córdoba, concluiu os estudos secundários no Colégio de Nacional de Montserrat. Em 1970, ingressou no curso de História da Faculdade de Filosofia da Universidade Nacional de Córdoba (UNC) e, um ano mais tarde, começou também a cursar Economia. Nesse período, Coggiola viveu uma fase de intensa militância: "Entre 1969 e 1975 fui preso uma dúzia de vezes devido às minhas atividades políticas, tanto por governos militares (até 1973), quanto sob o governo peronista (1973-1976). Cheguei a ficar dois meses na prisão...”. Em seguida, os militares golpistas de 24 de março de 1976 promoveram vários expurgos e perseguições em relação a militantes de esquerda. Expulso da universidade de Córdoba, Coggiola refugiou-se em Buenos Aires e, posteriormente, viajou para a França. Exilado em Paris, fez graduação em História e Economia na Universidade de Paris VIII entre 1976 e 1979. Depois de fazer uma especialização em História na mesma universidade, mudou-se para o Brasil em 1980 e trabalhou como pesquisador e professor visitante no Arquivo Edgard Leuenroth (AEL) da Unicamp até 1983. Nesse ínterim, voltou a Paris para defender o doutorado na Escola de Altos Estudos em Ciências Sociais de Paris com a tese $O$ Movimento Trotskista na Argentina, orientada pela Prof. ${ }^{a}$ Dra. Madeleine Rebérioux. De volta ao Brasil, prestou concurso público para a disciplina de História Contemporânea no Departamento de História da FFLCH-USP, no qual começou a ministrar aulas em 1985. Em 1992 defendeu a livre-docência com a tese $O$ Destino de uma Revolução. Ensaios sobre a História Contemporânea da URSS e do Leste Europeu. É professor titular de História Contemporânea desde 2003.

Wanderley Messias da Costa (Messias da Costa) nasceu em Arapongas, cidade localizada ao norte do Paraná, em 1950. No início dos anos 1960, migrou com a família para a cidade de Santos-SP: “Ainda no interior do Paraná fiz o primário na escola pública. Depois, em Santos, cursei o Clássico quando podíamos optar pelos cursos Científico, Clássico ou a Escola Normal. Fiz o Clássico no Colégio Canadá porque já tinha uma predileção pela área de ciências humanas", narrou Messias da Costa em entrevista. Cursou Geografia na FFLCH-USP entre 1973 e 1976, tendo realizado uma pesquisa em nível de Iniciação Científica (IC) financiada pela FAPESP que resultaria na publicação de um artigo: "Acho que fui um dos poucos alunos daquele período que teve uma bolsa de IC. Tratava-se de um artigo sobre a dinâmica climática da cidade de São Paulo e foi publicado pelo Boletim do Instituto de Geografia em 1976”, comentou o 
professor. Começou sua carreira docente como professor da rede estadual de ensino e em escolas particulares. Na Faculdade de Filosofia, sua primeira experiência foi como docente voluntário ministrando aulas de geografia para o curso de Ciências Sociais. Ingressou definitivamente como docente no Departamento de Geografia da Faculdade de Filosofia em 1981 mediante concurso público. Em 1982 defendeu o mestrado orientado pelo Prof. Dr. Armando Correa da Silva com a dissertação O Processo Contemporâneo de Industrialização: um estudo sobre a expansão industrial em território paulista. Em 1991, defendeu o doutorado apresentando a tese Geografia Política e Geopolítica: discursos sobre o território e o poder, também orientada pelo Prof. Dr. Armando Correa da Silva. Tornou-se livre-docente em 2005 por intermédio da defesa da tese Política e Território em tempos de Mudanças Globais. Em 2008, recebeu o prêmio Jabuti de melhor livro na categoria Ciências Naturais e Ciências da Saúde ao lado dos professores Bertha Becker e Diógenes Alves, com o livro Dimensões Humanas da Bioesfera - Atmosfera da Amazônia, publicado pela Edusp. Professor titular da FFLCH-USP desde 2008, Costa é, atualmente, diretor executivo da Fundação do Desenvolvimento Administrativo (FUNDAP).

Sandra Guardini Teixeira Vasconcelos (Vasconcelos) nasceu em Campinas em 6 de abril de 1950. Estudou em escolas públicas tanto no ensino primário como no secundário: "Eu sou um artigo raro nos dias de hoje, mas não na minha geração. Sou uma aluna de escola pública. Fiz toda a minha formação, aquilo que a gente chamava de escola primária e secundária em escola pública”. Depois de uma rápida experiência no primeiro ano de Letras na Pontifícia Universidade Católica de Campinas (PUCCAMP), trancou o curso e decidiu prestar o vestibular para ingressar na Faculdade de Filosofia da USP. Nesta instituição fez a graduação em Português e Inglês concluindo a mesma em 1975. Sob a orientação da Prof. ${ }^{a}$ Dra. Teresa de Jesus Pires Vara defendeu a dissertação Baú de Alfaias em 1984 e o doutorado intitulado Puras Misturas (O imaginário das estórias em Uma Estória de Amor de Guimarães Rosa), defendido em 1991. "Tanto o meu mestrado quanto o doutorado foram feitos na área de Teoria Literária e Literatura Comparada. Trabalhei com Guimarães Rosa tanto no mestrado quanto no doutorado", afirmou a professora. Vasconcelos ingressou como professora no Departamento de Letras Modernas da Faculdade de Filosofia da USP depois de concluir o mestrado através de um processo seletivo: "Na verdade, a universidade era mais livre do que é hoje. Por um lado, o ingresso do ponto de vista trabalhista era complicado, 
porque não havia concurso público. Passei por um processo seletivo, não foi um concurso que me dava qualquer tipo de amparo legal”. Durante 15 anos trabalhou mediante um contrato considerado precário, afinal não tinha qualquer amparo jurídico. Ao longo da carreira docente fez três pós-doutorados no exterior e, no ano 2000, defendeu a livre docência A Formação do Romance Inglês: ensaios teóricos. Publicada em livro, esta tese recebeu o Prêmio Jabuti na categoria Teoria/Crítica Literária em 2008. No mesmo ano obteve a "titulatura" no Departamento de Letras Modernas da FFLCH-USP.

Sérgio França Adorno de Abreu (Adorno) nasceu em São Paulo-SP no bairro Bela Vista em 1952. Sua família paterna era descendente de espanhóis e formada por camponeses pobres que migraram da região noroeste do estado de São Paulo para a capital. Seu pai concluiu a escola básica e trabalhou como escrevente em cartório: "Eu tinha estimulação, tinha biblioteca em casa. O meu pai formou a biblioteca dele em sebos. Tanto que depois quando tive que infelizmente me desfazer um pouco da biblioteca dele eu encontrei coisas incríveis". Já sua mãe é descendente de italianos e pertencia à uma família de classe média cujos membros eram profissionais liberais, funcionários públicos e executivos. "Fiz o primário em uma escola privada, mas depois realizei o ginásio e estudei sempre em escolas públicas. Até porque a escola pública era mais valorizada", comentou Adorno. Cursou o Clássico no Colégio Estadual Dr. Otávio Mendes e ingressou em Ciências Sociais na FFLCH-USP em 1971. Depois de graduarse em 1974, foi professor em cursos pré-vestibulares e trabalhou como escriturário na prefeitura de São Paulo. Concomitantemente a essas atividades, participou de um grupo de estudos coordenado pela Prof. ${ }^{a}$ Maria Célia Paoli que pesquisava violência e prisões. Em 1978 ingressou no mestrado sob a orientação do Prof. Dr. Gabriel Cohn: “Quando entreguei o trabalho, o Prof. Gabriel Cohn me disse que era uma tese de doutorado e sugeriu que eu fizesse o doutorado direto. Então tive que refazer o exame de qualificação já com um capítulo da tese e, a partir dessa requalificação, fui direto para o doutorado". A tese foi defendida em 1984 com o título A arte da prudência e da moderação: O Liberalismo e a Profissionalização dos Bacharéis na Academia de Direito de São Paulo, 1827-1883. Ingressou como professor no Departamento de Sociologia da FFLCH-USP em 1986 mediante concurso público. Em 1996 defendeu a livre-docência com a tese A gestão Urbana do Medo e da Insegurança (Violência, 
Crime e Justiça Penal na Sociedade Brasileira Contemporânea). Adorno obteve a titularidade em 2004 e, atualmente, exerce a direção da FFLCH-USP.

Ana Fani Alessandri Carlos (Alessandri Carlos) nasceu em 22 de maio 1952, na cidade de São Paulo: "Sou de uma família de imigrantes italianos pobres e morávamos na Barra Funda. Portanto, uma família que não tinha uma ligação muito grande com o mundo das letras. Tive que construir muita coisa". Fez o ensino primário em escola pública e cursou o Clássico no Colégio de Aplicação da USP: "Eu vinha de um colégio estadual, com método de ensino tradicional e, com o Curso Clássico no Colégio de Aplicação, a minha vida deu uma guinada monumental. Passei a me deparar com um universo que não conhecia". Alessandri Carlos contou durante a entrevista que a decisão de cursar Geografia foi tomada devido às aulas ministradas no colégio pelo Prof. Paulo Pedro Perides. Em 1975, concluiu a graduação em Geografia pela FFLCHUSP e, ao ingressar na pós-graduação, depois de cursar uma disciplina, começou a fazer parte de um grupo de estudos coordenado pelo Prof. Dr. José de Souza Martins. Durante 18 anos de estudos ininterruptos, o grupo leu primeiramente obras de Marx e, num segundo momento, livros de Henri Lefebvre: "A obra do Marx foi absolutamente central na minha vida. E foi através da obra do Marx e não dos marxianos, ou dos leitores do Marx, mas por dentro da compreensão da própria obra do Marx, que comecei a construir uma concepção de geografia”, comentou a professora. Alessandri Carlos defendeu sua dissertação de mestrado em 1979 com a tese Reflexões sobre o Espaço Geográfico, orientada pela Prof. ${ }^{a}$ Dra. Nice Lecoq Muller. Ingressou como docente no Departamento de Geografia da FFLCH-USP em 1982 e, em 1987, defendeu o doutorado com a tese $A$ (Re) produção do Espaço Urbano, orientada pela Prof. ${ }^{a}$ Léa Goldenstein. Sua tese de livre-docência chama-se Espaço tempo na vida cotidiana na metrópole e foi defendida no ano 2000. Carlos obteve a "titulatura" pelo Departamento de Geografia da USP em 2005 e, atualmente, coordena o Grupo de Estudos sobre São Paulo (GESP).

Apresentados os colaboradores que participaram da pesquisa que deu origem a esse trabalho, cabe conhecer as principais hipóteses que guiaram a construção da tese Uma comunidade docente entre a ditadura e a democracia. A hipótese central de que os docentes pertencentes à comunidade acadêmica estudada acumulavam uma experiência coletiva fronteiriça marcada pela história da Faculdade de Filosofia da USP e pelo episódio conhecido como "Batalha da Maria Antônia" que culminou com o seu 
fechamento em 1968. A esse evento, soma-se a posterior reorganização administrativa da Faculdade promovida pela instauração de uma nova legislação para o ensino superior publicada a partir da Lei 5540/68 ${ }^{18}$. A comunidade docente pesquisada distingue-se pelo fato de ser tributária de duas culturas universitárias diferentes, portanto, formada pelos primeiros professores titulares que assumiram os principais cargos de chefia após o domínio dos catedráticos. Trata-se, portanto, de um grupo que viveu uma série de embates acadêmicos pertencentes ao processo de transição do regime de cátedras para o departamental. Processo esse, não obstante, que transcorreu imbricado ao longo e trançado processo de redemocratização política do país. Nesse sentido, coube pensar as múltiplas relações entre as mudanças ocorridas dentro e fora da universidade e investigar como os docentes se posicionaram diante dessas transformações.

O primeiro capítulo, A formação de uma comunidade docente entre a ditadura e a democracia, examinará os marcos identitários de uma comunidade docente tributária de uma cultura acadêmica baseada na tradição da Faculdade de Filosofia e, ao mesmo tempo, partícipe do processo de departamentalização e profissionalização da carreira universitária inaugurado pela Lei 5540/68. Por meio das entrevistas de história oral de vida, apresentar-se-á como foi desenhado o processo de negociação entre as memórias individuais e coletivas. No que tange a construção do imaginário político e cultural dos intelectuais estudados, serão observadas as experiências de resistência compartilhadas durante a ditadura militar, as marcas cotidianas deixadas pelas cassações de professores e perseguições a alunos da Faculdade de Filosofia que culminaram com a "Batalha da Maria Antônia", o fechamento do prédio que abrigava a faculdade e a transferência de suas atividades para a cidade universitária.

No segundo capítulo, Uma comunidade docente em transição no contexto democrático, pretende-se apresentar os principais conflitos existentes dentro da comunidade docente, destacando-se as vozes dissonantes e as disputas em torno do processo de democratização política. Como as memórias individuais são sempre dinâmicas e se renovam permanentemente a partir do diálogo que estabelecem com a

\footnotetext{
${ }^{18}$ As reformas promovidas por essa lei determinaram: o desaparecimento das cátedras ou cadeiras como unidades básicas do ensino e da pesquisa, substituídas pelos departamentos, que aglutinariam os docentes pertencentes às disciplinas afins; a integração das várias áreas que desenvolviam ensino e pesquisa comum; a criação dos assim chamados cursos básicos (primeiro ciclo) e profissionais (segundo ciclo); o estabelecimento das matrículas por disciplina, em substituição às tradicionais matrículas por série; e a extinção das Faculdades de Filosofia, Ciências e Letras. Ver: CUNHA, L. A. A universidade reformanda. Op. cit..
} 
memória coletiva, serão analisadas as principais divergências em relação à gestão da Faculdade de Filosofia, ao processo de profissionalização docente e ao papel político dos intelectuais.

O terceiro e último capítulo, Entre a profissão e a docência: memória coletiva e universidade pública, apresentará uma síntese do processo de negociação mediado pela comunidade docente em relação à função dos docentes enquanto intelectuais públicos. Afinal, qual a mensagem que os professores querem transmitir ao grande público? Nesse sentido, serão examinadas suas posições quanto ao papel dos intelectuais no mundo contemporâneo e sua avaliação em relação à missão da Faculdade de Filosofia. 


\section{Capítulo 1: A formação de uma comunidade docente entre a ditadura e a democracia.}

\subsection{Origens da Faculdade de Filosofia da Universidade de São Paulo.}

Criada em 1934, após a perda da hegemonia política do Estado de São Paulo no plano nacional em consequência do golpe de Estado realizado por lideranças do movimento tenentista em parceria com a Aliança Liberal dirigida por Getúlio Vargas em outubro de 1930 e a derrota na campanha militar de 1932, a Universidade de São Paulo tinha a missão de formar novos quadros profissionais que seriam responsáveis pelo fortalecimento da autonomia cultural, política e econômica da elite paulista ${ }^{19}$. No bojo da defesa da uma universidade para São Paulo, encontra-se um aranzel de argumentos que enalteciam a trajetória vitoriosa dessa mesma elite e referências ao bandeirismo, ao republicanismo histórico e ao pioneirismo industrial do estado ${ }^{20}$.

O projeto era parte de um plano mais amplo articulado pelo chamado "grupo do Estado" (referência ao Jornal O Estado de São Paulo e ao grupo encabeçado por Júlio de Mesquita Filho, Armando Sales Oliveira, Fernando de Azevedo, Paulo Duarte, entre outros) ainda na década de 1920 e cujo propósito era a "emancipação definitiva" do país e a resolução de problemas de ordem institucional e cultural. Segundo Júlio de Mesquita Filho, atenção especial deveria ser dada ao "problema cultural", a partir do qual a construção de universidades tornava-se uma prioridade, já que a função delas "seria a de formar as elites indispensáveis à obra de regeneração política da sociedade brasileira e à superação da crise nacional, com a destruição do poder das oligarquias, 21 .

A proposta educacional e, particularmente, de ensino universitário defendido por Júlio de Mesquita e pelo "grupo do Estado" - como demonstra Irene Cardoso ao

\footnotetext{
${ }^{19}$ SCHWARTZMAN, S. Formação da comunidade científica no Brasil. São Paulo: Nacional, Rio de Janeiro: Finep, 1979, p. 195.

${ }^{20}$ Para uma compreensão das disputas políticas que envolviam o Estado de São Paulo e o governo federal liderado por Getúlio Vargas, ver: LEVINE, R. Pai dos Pobres? O Brasil e a Era Vargas. São Paulo: Cia das Letras, 2001.

${ }^{21}$ CARDOSO, I. A Universidade da Comunhão Paulista - o projeto de criação da Universidade de São Paulo. São Paulo: Autores Associados, 1982, p.37.
} 
analisar o "Inquérito sobre a Educação no Estado de São Paulo" escrito por Fernando de Azevedo e publicado pelo O Estado de São Paulo (OESP) em $1926^{22}$-, estava baseada em uma concepção de sociedade peculiar e cuja proposta pedagógica era tipicamente liberal e burguesa: previa e delimitava funções específicas para aqueles que pertenciam a estratos sociais diferentes. Assim, o projeto de uma universidade para São Paulo, estava inserido nas concepções da Escola Nova que, por sua vez, estabelecia que o ensino primário deveria atender às massas e o secundário às classes médias, enquanto caberia à universidade filtrar e preparar as elites para a condução do país ${ }^{23}$.

Como argumentava Fernando de Azevedo:

\begin{abstract}
A preparação das elites intelectuais precedeu sempre, em toda a parte, a instrução das massas. A primazia da universidade sobre os outros níveis de ensino deve-se ao fato de que é nela que se forma a elite dirigente indispensável à obra de regeneração política da nacionalidade, capaz de propor um projeto que seria assimilado e propagado por uma "corrente de opinião" constituída pela classe média formada pelo ensino secundário ${ }^{24}$.
\end{abstract}

No contexto de fundação da Universidade de São Paulo havia dois projetos em jogo e que divergiam quanto ao papel da Faculdade de Filosofia, Ciências e Letras (FFCL). O primeiro era parte dos Decretos Números 19851 e 19852 de 1931, publicados na gestão de Francisco Campos no Ministério da Educação, que reformulavam o ensino superior e instituíam as universidades brasileiras. O segundo, dizia respeito ao Plano da USP redigido por Fernando de Azevedo a pedido de Júlio de Mesquita Filho e Armando de Salles Oliveira. Para Irene Cardoso, enquanto aquele defendia a criação de uma Faculdade de Educação, Ciências e Letras, enfatizando o caráter de Instituto de Educação dessa faculdade, o projeto gestado pelo "grupo do Estado" pretendia garantir "uma função superior e inalienável da formação e do preparo das classes dirigentes", sendo explícita e consciente a função política da Faculdade de Filosofia, Ciências e Letras da USP ${ }^{25}$.

\footnotetext{
${ }^{22}$ Idem, pp.46-68.

${ }^{23}$ Para uma definição de Pedagogia Liberal Burguesa e um exame apurado sobre a Escola Nova, ver: SAVIANI, D. Escola e Democracia. São Paulo, Autores Associados, 1989.

${ }^{24}$ CARDOSO, I. Idem, p. 30 e p.42. Fernando de Azevedo explicitaria suas concepções sobre a universidade no Manifesto dos Pioneiros da Escola Nova publicado em 1932, cujos princípios seriam incorporados ao Plano da USP, elaborado a pedido de Júlio de Mesquita Filho, e base para a fundação da USP em 1934.

${ }^{25}$ CARDOSO, I. Idem, p. 99.
} 
O "grupo do Estado" estava convicto de que o desempenho político da Faculdade de Filosofia, Ciências e Letras definiria as características da universidade como um todo, já que a dificuldade inicial estava na união das chamadas "três grandes escolas": as Faculdades de Direito e de Medicina e a Escola Politécnica. Coube à Faculdade de Filosofia, Ciências e Letras (FFCL) um papel integrador, idealmente considerado por alguns como a "alma da Universidade":

Ou o eixo central ou a célula mater onde seria promovida a pesquisa em tempo integral, contribuindo para um conhecimento universal, puro e desinteressado, ficando a aplicação da ciência para as escolas profissionais; que seria autônoma do ponto de vista administrativo e acadêmico; que formaria uma elite cultural dinâmica, capaz de assumir a liderança no processo de superação do estado de atraso em que se encontrava o país ${ }^{26}$.

Segundo Florestan Fernandes, a Faculdade de Filosofia manteve-se distante das querelas políticas e sociais ao longo do Estado Novo, quando tanto as tendências fascistas, quanto os ideais liberais e conservadores do "grupo do Estado" defendiam a premissa do afastamento entre os intelectuais e o poder político. Para o autor, prevalecia na Faculdade de Filosofia da USP uma concepção de intelectual e, em particular de professor, segundo a qual o mais importante era a manutenção de "uma atitude de neutralidade ética com relação aos problemas da vida e com relação aos valores". Para Fernandes, esse posicionamento em relação à formação do professor foi nefasto para a universidade e para a educação no país, já que:

É o caminho pelo qual o especialista, saindo da escola normal ou da universidade, norteia-se em termos de uma relação de responsabilidade com a sociedade, isto é, com a ordem. Ele não é colocado em relação de tensão, mas de acomodação. E quando ele abre o caminho da tensão, abre por outras vias, que não são estimuladas através do ensino e da pesquisa. A essa concepção correspondeu a ideia de que era necessário separar o cidadão do cientista e do professor. Essa distinção foi fatal para minha geração. (...) Se o professor não tiver em si a figura forte do cidadão, acaba se tornando instrumental para qualquer manipulação, seja ela democrática ou totalitária ${ }^{27}$.

\footnotetext{
${ }^{26}$ SCHWARTZMAN, S.. Op. cit., p.197.

${ }^{27}$ FERNANDES, F. “A Formação política e o trabalho do professor”. In: O Desafio Educacional. São Paulo: Cortez, 1989, p.163.
} 
Assistente de Fernando de Azevedo e admirador de muitas de suas iniciativas, Fernandes se opunha, contudo, ao modelo de universidade defendido pelo primeiro e, em particular, de Faculdade de Filosofia e de Instituto de Educação, através dos quais não se investia em disciplinas voltadas para a capacitação política do professor. Consequentemente esse professor acabava se profissionalizando, porém, sem enfrentar e nem compreender o seu papel político e social como intelectual.

Os debates em torno da questão da luta em defesa da escola pública desaguaram em uma ampla mobilização estudantil pela resolução do problema dos chamados "alunos excedentes". Esta nomenclatura era utilizada para designar os estudantes que eram aprovados pelo exame de admissão na Universidade de São Paulo, mas não conseguiam ingressar na instituição pela falta de vagas disponíveis. O movimento em defesa dos excedentes, dentre outras coisas, rejeitava o vestibular como mecanismo de seleção e afirmava que ninguém deveria ser excluído da universidade por falta de vagas. Segundo Cunha, em 1960 havia 29 mil excedentes que passaram para $162 \mathrm{mil} \mathrm{em}$ $1969^{28}$.

As manifestações estudantis que passaram a reivindicar acesso ao ensino superior no final da década de 1950 e as campanhas em prol da educação pública contribuíram para que se iniciasse na Universidade de São Paulo a quebra de um círculo autoritário ${ }^{29}$. Nesse mesmo contexto, a fórmula conservadora vigente que procurava separar o docente das suas convicções como cidadão, começava a ser questionada. E a universidade que tinha sido criada para atender exclusivamente aos anseios das elites foi obrigada a conviver com interesses contraditórios ${ }^{30}$.

Os conflitos entre os interesses das "classes médias" e das elites vieram à tona quando explodiu o golpe civil-militar de 1964: se a USP não reagiu oficialmente à ditadura, também não cedeu como um todo. Havia professores e estudantes entrincheirados e dispostos a resistir no antigo prédio da Rua Maria Antônia. A Faculdade de Filosofia foi a única da Universidade a não soltar um manifesto de apoio

\footnotetext{
${ }^{28}$ CUNHA, L. A. "A demanda reprimida". In: CUNHA, L. A. A universidade reformanda. Rio de Janeiro: Francisco Alves, 1988, pp. 86-91.

${ }^{29}$ Essas lutas vieram acompanhadas da expansão efetiva da USP a partir dos anos 1950 e da fundação de novos campi em cidades do interior do Estado. Hoje, ao todo, a universidade é formada pelo Campus da Cidade Universitária-SP, Ribeirão Preto, Bauru, São Carlos, Pirassununga, Piracicaba, Lorena e Campus da USP-Leste também na capital.

${ }^{30}$ RIDENTI, M. Professores e Ativistas da Esfera Pública. São Paulo: Cortez, 1995, pp.13-55.
} 
aos generais, "apesar da maioria dos professores titulares naquele momento serem favoráveis aos militares", como contou Paulo E. Arantes:

\begin{abstract}
Quando entrei no curso de filosofia, o golpe militar estava completando um ano. Soube depois que a Congregação da Faculdade fora a única a não soltar manifesto de apoio aos generais. Recordo a explicação simpática de Antônio Candido: o ato de discreta resistência devia-se menos a convicções - a maioria dos titulares era favorável aos militares - do que ao prestígio de uma instituição que encarnava de maneira superlativa o espírito de crítica e livre exame; pois esta atmosfera progressista - em que prosperou o sempre lembrado pensamento radical de classe média, responsável, em outros feitos, pela primeira visão não-aristocrática do Brasil - teve peso suficiente para desestimular demonstrações reacionárias ostensivas ${ }^{31}$.
\end{abstract}

No início da década de 1960, a Faculdade de Filosofia destacava-se no cenário político nacional por intermédio de alguns professores engajados na Campanha de Defesa da Escola Pública, no debate a respeito das Reformas de Base - até mesmo no que dizia respeito à questão da Reforma Universitária - e na participação de estudantes durante a Greve do 1/3 ocorrida entre maio e agosto de 1962. Segundo o Livro Negro da $U S P$, as divergências em relação às propostas dos grevistas provocaram uma grande polarização dos professores: enquanto um grupo foi organizado em torno dos adeptos da democratização da universidade, outro firmou posição reunindo os conservadores que defendiam intransigentemente os privilégios da cátedra ${ }^{32}$.

Após o golpe civil-militar de 1964, as posições políticas dos professores da USP ficaram ainda mais evidentes quando um grupo se aliou ao reitor Gama e Silva - que ocupava provisoriamente as pastas da Justiça e da Educação no governo Castelo Branco - em defesa dos militares; enquanto outro passava a ser perseguido por uma Comissão de Inquérito criada pela própria reitoria. O objetivo da Comissão de Inquérito era punir os "responsáveis por infiltrar ideias marxistas", "sendo agentes de processos subversivos dentro da universidade".

$\mathrm{Na}$ contramão das medidas repressivas que atingiam a universidade pública, foram formadas Comissões Paritárias no interior da Universidade de São Paulo, que nasceram a partir da discussão iniciada em 1967 em torno da reformulação do currículo de alguns cursos como Ciências Sociais e Geologia. As Comissões Paritárias de alunos e

\footnotetext{
${ }^{31}$ ARANTES, P. E. "O bonde da filosofia - aspectos da cultura filosófica uspiana nos últimos anos da Rua Maria Antônia (1965-1968). In: SANTOS, M. C. L. dos. (org.) Maria Antônia: uma rua na contramão. São Paulo: Nobel, 1988, p.184.

${ }^{32}$ ADUSP. O controle ideológico na USP (1964-1978). Op. cit., p.16.
} 
professores vingaram, primeiramente, nas Ciências Sociais, graças ao apoio concedido pelos auxiliares de ensino. Segundo Cunha, “em oposição à universidade existente, a Comissão Paritária da FFCL projetou a universidade crítica, também chamada de universidade nova" e ganhou a adesão de outras unidades da USP:

A divulgação do Relatório Ferri, em junho, induziu, como reação contrária, a formação de comissões paritárias em outras seções da FFCL e em outras unidades. Nessa Faculdade, onde a influência de estudantes e professores de Ciências Sociais se fazia sentir mais fortemente, foi organizada uma comissão, também paritária, em nível de unidade - chamada comissão geral - com representantes das comissões seccionais. Uma comissão paritária da USP foi proposta no Conselho Universitário, surpreendentemente por um professor catedrático, mas não chegou a produzir resultados ${ }^{33}$.

Enquanto alunos e professores negociavam a reformulação pedagógica dos cursos e disciplinas e debatiam questões administrativas, o movimento estudantil intensificou suas ações públicas em 1968 e o trabalho no interior da universidade, em especial, no prédio da Rua Maria Antonia, transformado em um dos centros contestadores do regime. Atenta à articulação das forças políticas progressistas no interior da instituição, a ditadura fez vistas grossas ao ataque efetuado pelo Comando de Caça aos Comunistas (CCC) a partir do prédio da Universidade Mackenzie: pedras e bombas foram jogadas, além de tiros terem sido disparados com armas de fogo. Estudantes e professores permaneceram defendendo o patrimônio público até a retirada forçada. $\mathrm{O}$ atentado contou com a omissão da Reitoria da USP, da polícia paulista e do governo do Estado ${ }^{34}$.

Os ataques de 2 e 3 de outubro marcaram sensivelmente a história da Faculdade de Filosofia, Letras e Ciências e mantiveram-se como referência nos embates políticos travados durante o processo de transição da ditadura para a democracia política. Além disso, a "Batalha da Maria Antônia" impôs a interdição do prédio e a transferência da Faculdade e de seus cursos para barracões improvisados na Cidade Universitária. A promulgação do AI-5 em 12 de dezembro de 1968 permitiu que em 25 de abril de 1969 fosse publicado o primeiro decreto que punia professores da Universidade de São Paulo.

\footnotetext{
${ }^{33}$ Ver: CUNHA, L. A. A universidade reformanda. Op. cit, p. 155-6.

${ }^{34}$ A Rua Maria Antônia (São Paulo-SP), onde se situavam a Universidade Mackenzie e a Faculdade de Filosofia, Ciências e Letras da Universidade de São Paulo, foi palco do conflito que ficou conhecido como "A Batalha da Maria Antônia", ou "Guerra da Maria Antônia". A PM interviu, o secundarista José Guimarães foi morto por um tiro disparado pelo Comando de Caça aos Comunistas - CCC, alojado no alto de um prédio do Mackenzie. Ver: CARDOSO, I. "Maria Antonia: o edifício de n 294". In: CARDOSO, I. Para uma crítica do presente. São Paulo: Ed. 34, 2001, pp.101-108.
} 
Entre 42 pessoas atingidas e diversos intelectuais, havia três professores da USP: Florestan Fernandes, Jayme Tiomno e João Batista Villanova Artigas. Apenas quatro dias depois, um novo decreto foi publicado atingindo 24 professores da USP, sendo que seis deles foram ligados incorretamente à instituição ${ }^{35}$.

Por uma irônica coincidência histórica a tentativa de destruir a Instituição, simbolizada na depredação e interdição do edifício de $\mathrm{n}^{\circ}$ 294, realizava-se no mesmo momento em que se dissolvia a FFCL, no interior da estrutura universitária. A dimensão simbólica dessa dupla destruição é extremamente contundente se se pensar nos seus posteriores desdobramentos. (...) A Instituição, que tinha antes uma função de coordenação, passa a ter, agora, de modo crescente, a de ordenação da vida universitária. Com isso, atividade intelectual está hoje cada vez mais subordinada à realidade institucional... A realidade institucional passa a estabelecer, hoje, os limites da atividade intelectual $^{36}$.

O ensino superior no Brasil sofreu significativas mudanças a partir das orientações traçadas pela United States Agency for International Developement (USAID) e dos decretos aprovados com base nos chamados “Acordos MEC-USAID”. Em geral, os decretos aprovados tinham como objetivo controlar o movimento estudantil que tomava as ruas e, implantar no interior das universidades, um modelo de administração empresarial estabelecendo regras que visavam o alcance de metas tais como economia de recursos e aumento de produtividade. Segundo Otaíza Romaneli:

\footnotetext{
${ }^{35}$ O primeiro decreto de 25 de abril de 1969 providenciava a aposentadoria dos seguintes servidores públicos: Aberlardo Zaluar, Alberto Coelho de Souza, Alberto Latôrre de Faria, Augusto Araújo Lopes Zamith, Aurélio Augusto Rocha, Bolivar Lamounier, Carlos Alberto Portocarrero de Miranda, Eduardo Moura da Silva Rosa, Elisa Esther Frota Pessoa, Eulália Marias Lahamayer Lobo, Florestan Fernandes, Guy José Paulo de Holanda, Hassim Gabriel Merediff, Hélio Marques da Silva, Hugo Weiss, Ildico Maria Erzsebet, Jayme Tiomno, João Batista Villanova Artigas, João Cristóvão Cardoso, João Luís Duboc Pinaud, José Américo da Mota Pessanha, José Leite Lopes, José de Lima Siqueira, Lincoln Bicalho Roque, Manoel Maurício de Albuquerque, Maria Célia Pedroso Torres Bandeira, Maria Helena Trench Villas Boas, Maria Heloisa Villas Boas, Maria José de Oliveira, Maria Laura Mouzinho Leite Lopes, Maria Yedda Leite Linhares, Marina São Paulo de Vasconcellos, Marina Coutinho, Mário Antônio Barata, Milton Lessa Bacios, Mirian Limoeiro Cardoso Lins, Moema Eulália de Oliveira Toscano, Plínio Sussekind da Rocha, Quirino Campofiorito, Roberto Bandeira Accioli, Sara de Castro Barbosa e Wilson Ferreira Lima. O segundo decreto de 29 de abril de 1969 providenciava a aposentadoria dos seguintes servidores públicos: Alberto de Carvalho da Silva, Bento Paulo Almeida Ferraz Junior, Caio Prado Júnior, Elza Salvatori Berquó, Emília Viotti da Costa, Fernando Henrique Cardoso, Hélio Lourenço de Oliveira, Isaías Raw, Jean Claude Bernardet, Jon Andoni Vergareche Maitrejean, José Arthur Gianotti, Júlio Puddles, Luiz Hildebrando Pereira da Silva, Luiz Rey, Mário Schenberg, Octávio Ianni, Paulo Mendes da Rocha, Olga Baeta Henriques, Paula Beiguelman, Paulo Alpheu Monteiro Duarte, Paulo Israel Singer, Pedro Calil Padis, Reynaldo Chiaverini, Sebastião Baeta Henriques. Ver: ADUSP. O controle ideológico na USP (1964-1978). Op. cit., pp.45-49.

${ }^{36}$ Idem, pp.114-115.
} 
O Decreto-Lei $\mathrm{n}^{\circ} 252$ de 28 de fevereiro de 1967, determinou que cada unidade universitária fosse estruturada em unidades menores, chamadas departamentos, que deveriam reunir disciplinas afins. Eliminou-se, assim, a possibilidade de coexistência de disciplinas idênticas ou afins, multiplicadas por várias secções ou unidades. Concentrava-se, com isso, o ensino e a pesquisa de uma mesma área em departamentos, o que deu grande economia à utilização de recursos ${ }^{37}$.

A antiga FFLC situada na Rua Maria Antônia transformava-se na Faculdade de Filosofia, Letras e Ciências Humanas da Universidade de São Paulo (FFLCH-USP) como resultado de um processo de otimização de recursos econômicos orquestrado pela Lei 5540/68. Esta, por sua vez, baseava-se nas orientações de Rudolph Atcon presentes no livro Rumo à Reformulação Estrutural da Universidade Brasileira e em um fundamentalismo de mercado que passou a gerenciar a administração do ensino superior e das universidades brasileiras de acordo com a "teoria" do capital humano ${ }^{38}$.

Para Gaudêncio Frigotto, a Reforma Universitária de 1968 e a Lei de Diretrizes e Bases da Educação de 1971, implantadas no Brasil pelos agentes da AID em parceria com o MEC, tiveram origem em princípios propostos pela "teoria do capital humano", desenvolvida por Theodoro Schultz nos anos 1950 e que lhe rendeu o Prêmio Nobel de Economia de 1968. Na concepção de Frigotto, o principal pressuposto da "teoria do capital humano" “... é a da educação ser produtora de capacidade de trabalho”, ou seja, de que a escola "ensina técnicas específicas e determinados valores e atitudes funcionais ao mundo da produção",39.

Vale ressaltar que o processo de modernização baseado no modelo norte americano, como demonstrado por Luiz Antônio Cunha, vinha sendo colocado em prática desde a década de 1940, chegando, contudo, a sua forma definitiva através da implantação das concepções de Rudolph Atcon:

Considero a difusão da ideia da privatização da universidade erroneamente identificada à sua autonomia - o principal aspecto negativo da pregação desse consultor. Se ele não foi o primeiro a sugeri-la, ninguém conseguiu ser tão convincente, aproveitando um momento propício para disseminar a ideia de que a universidade é ou deve funcionar como se fosse uma empresa privada. Como nestas, não se colocaria a questão da representação das diversas categorias de

\footnotetext{
${ }^{37}$ ROMANELLI, O. de O. História da Educação no Brasil. Petrópolis: Vozes, 1984, p. 217.

38 SAVIANI, D. "A questão teórica na constituição do espaço acadêmico da pedagogia no Brasil”. In: $A$ Pedagogia no Brasil: história e teoria. Campinas: Autores Associados, 2008, pp.109-111.

${ }^{39}$ FRIGOTTO, G. Educação e a crise do capitalismo real. São Paulo: Cortez, 2000, pp. 40-42.
} 
participantes na sua gestão: os conselhos, poucos e pequenos, teriam apenas funções de assessoria. Seria o reitor - como o presidente de um conselho de acionistas de sociedade anônima - que contrataria um administrador para gerir sua universidade, como se fosse uma fábrica, uma loja, um hospital, etc., supostamente empenhados na busca dos melhores objetivos: produzir mercadorias e serviços que, vendidos, resultariam numa receita compensadora diante dos custos ${ }^{40}$.

Nesse sentido, a Lei 5540/68 impôs reformas que tinham por objetivo aperfeiçoar economicamente a universidade e sintonizar sua estrutura administrativa a novas perspectivas pedagógicas que priorizavam exigências externas atreladas à produção industrial e ao desenvolvimento econômico orquestrado pelos militares. A extinção da antiga Faculdade de Filosofia enquanto um complexo interdisciplinar responsável pela formação básica humanista, a criação de cursos de curta duração e, até mesmo, o fim da cátedra - que, por motivos diversos, também era uma reivindicação presente na pauta do movimento estudantil -, faziam parte de um projeto que circunscrevia as universidades à lógica da aplicação de recursos em educação mediante a maximização de resultados economicamente viáveis:

\begin{abstract}
Assim, pois, a modernização da universidade ocorreu menos por pressão da rebelião estudantil do que pela descoberta de que a inovação poderá ser manipulada sem ameaças à estrutura de poder, ao mesmo tempo em que se ajustaria mais a um certo padrão de desenvolvimento econômico, apontado este aspectos pelas forças internas e externas interessadas nessa modernização. Assim, pois, o governo não só cedeu às pressões, como também assumiu a responsabilidade da inovação ${ }^{41}$.
\end{abstract}

Segundo Maria de Fátima de Paula o Estatuto da Universidade de São Paulo aprovado em 1970 "apresenta nítida influência da Lei 5540 e do modelo norteamericano de universidade, as unidades são classificadas em Institutos, Faculdades e Escolas. Dentre essas unidades encontra-se a Faculdade de Filosofia, Letras e Ciências Humanas $" 42$. Ainda segundo o Estatuto citado pela autora, as finalidades da USP passavam a ser:

\footnotetext{
${ }^{40}$ CUNHA, L. A. Op. cit., p.324. Segundo Maria de Lourdes A. Fávero, "é pertinente lembrar que Rudolph Atcon não só foi convidado a organizar e estruturar o Conselho de Reitores das Universidades Brasileiras (CRUB), fundado em abril de 1966, mas nele trabalhou, como seu primeiro Secretário-Geral, de 1966 a 1968". Ver: FÁVERO, M. de L. A.. A universidade no Brasil: das origens à Reforma Universitária de 1968. Educar, Curitiba, n. 28, p. 17-36, 2006, p. 31.

${ }^{41}$ ROMANELLI, O. de O. Op. cit., p. 231.

${ }^{42}$ Segundo Maria de Fátima de Paula "a Reforma da USP realizada entre 1969 e 1970, transformou a
} 
Em primeiro lugar, o desenvolvimento e a promoção da cultura, por meio do ensino e da pesquisa; em segundo lugar, a formação de pessoas aptas ao exercício da investigação filosófica, científica, artística, literária e desportiva, bem como ao do magistério e de atividades profissionais; e, em terceiro lugar, a prestação de serviços à comunidade $^{43}$.

O isolamento da recém-criada FFLCH-USP no novo campus universitário do Butantã, somado às aposentadorias compulsórias de professores e às reformas no ensino superior impostas pelos militares e orientadas pelos acordos MEC-USAID a partir dos primeiros decretos aprovados em 1966, poderiam ter alterado o rumo de suas atividades de ensino e pesquisa em uma direção extremamente conservadora. Aqueles que permaneceram na Faculdade de Filosofia, no entanto, mesmo vigiados pela "ditadura do silêncio" - de que tratou Florestan Fernandes -, se incumbiram da missão de recompor as bases de resistência rearticulando as forças progressistas dispostas a combater o modelo educacional e de universidade imposto pelo regime militar.

Trincheiras foram cavadas com a ajuda de novas gerações de jovens professores e estudantes para resistir ao avanço do autoritarismo e defender a todo custo a liberdade de pensamento no interior da academia. Além disso, algumas bases de resistência foram também montadas fora da universidade e contaram com a presença maciça de professores e pesquisadores da FFLCH desde a sua fundação, como, por exemplo, foi o caso do CEBRAP e também do Centro de Estudos de Cultura Contemporânea (CEDEC).

Os responsáveis por atuar nas diferentes frentes de resistência no contexto da ditadura militar deram origem a uma comunidade docente que acompanhou a reestruturação da universidade em todos os níveis, a implantação de um novo modelo de carreira docente que formalizava o fim das cátedras e profissionalizava a atuação na academia segundo novos parâmetros. Resultado, muitos daqueles que fizeram parte desse contexto, tanto como professores quanto como alunos, vieram a compor as

Faculdade de Filosofia Ciências e Letras (FFCL) dividindo-a em várias unidades. As ciências exatas e naturais desmembraram-se transformando-se em institutos autônomos. Formava-se a Faculdade de Filosofia, Letras e Ciências Humanas (FFLCH) que, em 1970, tinha a seguinte formação: Ciências Sociais, Filosofia, História, Geografia, Letras Clássicas e Vernáculas, Letras Modernas, Linguística e Línguas Orientais". FÁTIMA DE PAULA, M. de. A modernização da universidade e a transformação da intelligentzia universitária. Florianópolis: Insular, 2002, p. 202.

${ }^{43}$ Estatuto da Universidade de São Paulo, São Paulo, USP, 1970, p.1. Apud: FÁTIMA DE PAULA, M. de. Op. cit., p.198. 
primeiras gerações de professores titulares após o encerramento das cátedras. As principais características dessa comunidade docente serão abordadas a seguir.

\subsection{Uma comunidade docente entre duas culturas universitárias.}

Da Rua Maria Antônia ao campus atual, mudou o capitalismo brasileiro. Era natural que se estilizasse a fase pretérita. Daí à bobagem basta um passo, que os paladinos da Cultura não hesitam em dar. Passo em falso, que não salva da mesma ameaça o sentimento complementar de que não se faz mais luta de classes como antigamente ${ }^{44}$.

O esforço desse capítulo é o de precisar e identificar o que molda a identidade e forma o sprit de corp do grupo de docentes estudado. Para tanto, se fez necessário conhecer as forças motrizes que impulsionaram a formação desses intelectuais e compreender como o contexto econômico, político e cultural interferiu nesse processo. Desse modo, pretende-se costurar uma história que não seja "cativa da memória", que não se reduza a uma "história de identidades" relativista e que seja capaz de interrogar permanentemente as relações entre micro e macro história ${ }^{45}$. Trata-se, enfim, de uma micro-história preocupada em dialogar com a totalidade, nos termos singularmente modernos estabelecidos por Karel Kosík ${ }^{46}$.

A tese aborda um conjunto de intelectuais formado por diferentes gerações que dividiram experiências em comum dentro e fora de universidade. O que qualifica e emoldura o grupo pesquisado é o fato de ele ter compartilhado uma formação que mesclava ensinamentos anteriores às mudanças instituídas em 1968, com atributos que passaram a ser desenvolvidos ao longo do processo de profissionalização da carreira universitária.

\footnotetext{
${ }^{44}$ ARANTES, P. Um departamento francês de ultramar: estudos sobre a formação da cultura filosófica uspiana - uma experiência nos anos 60. São Paulo: Paz e Terra, 1994, p.56.

${ }^{45}$ Bezerra de Menezes, U. "A História, Cativa da Memória? Para um mapeamento da memória no campo das Ciências Sociais". Rev. Instituto de Estudos Brasileiros, SP, 34; 9-24, 1992. Sobre a questão da identidade, ver: SILVA, T. T. "A produção social da identidade e da diferença". In: SILVA, T. T. (org) Identidade e diferença: a perspectiva dos estudos culturais. Rio de Janeiro: Vozes, 2000. Ver também: HOBSBAWM, E. "Não basta história de identidade". In: HOBSBAWM, E. Sobre a História. São Paulo: Cia das Letras, 2005, pp.281-292.

${ }^{46}$ KOSÍK, K. Dialética do concreto. Rio de Janeiro: Paz e Terra, 2010.
} 
Alfredo Bosi escreveu no final dos anos 1970 um ensaio chamado Cultura Brasileira e Culturas Brasileiras ${ }^{47}$, no qual examinou as transformações sofridas pela cultura universitária e os demais níveis de ensino no país. Em sua análise, constatou que as mudanças educacionais implementadas durante a ditadura civil e militar haviam provocado um “decréscimo rápido e talvez irreversível dos estudos clássicos tradicionais (Grego, Latim, Filologia e Francês)" e, consequentemente, "o desaparecimento de um certo tipo de formação letrada clássica e da capacidade de interpretação histórica concreta". Dentre as várias alterações criticadas, enfatizou a cristalização de um novo modelo educacional baseado em um "corpo de doutrina sóciopolítica forrado de ideais neocapitalistas”, destacando a implantação de disciplinas intituladas como: Organização Social e Política do Brasil (primeiro e segundo graus) e Estudos de Problemas Brasileiros (segundo e terceiro graus). Bosi lembrou ainda a retirada abrupta da disciplina de Filosofia da escola secundária e a introdução da disciplina de "Estudos Sociais" que tinha o intuito de substituir aquelas já conhecidas pelos alunos: História Geral, de Geografia Geral, de História do Brasil e de Geografia do Brasil. A gradual exclusão do ensino de Francês como língua opcional nos cursos médios e superiores e a instauração dos vestibulares unificados, promoviam os ajustes finais que colocavam um ponto final na cultura universitária que tinha sido responsável pela formação da geração de Bosi.

Cabe a partir das rupturas apontadas pelo ensaio de Bosi, investigar ainda a emergência da modernização conservadora promovida pelo regime militar no contexto do capitalismo periférico ${ }^{48}$ e seus reflexos nas políticas educacionais. A um só tempo, a comunidade docente estudada é resultado de um processo de rupturas e continuidades no plano econômico, político e social que atingiram o Brasil e o mundo nos anos 1970. A profissionalização da carreira universitária, marcada entre outras medidas, pela substituição do regime de cátedras e a instauração paulatina dos concursos públicos, precisa ser compreendida em um contexto histórico-cultural e econômico mais amplo: de mudanças na dinâmica econômica, de internacionalização do modelo norteamericano de universidade e, finalmente, do refluxo das referências modernas e da

\footnotetext{
${ }^{47}$ Ver: BOSI, A. "Cultura Brasileira e Culturas Brasileiras". In: Companhia das Letras, 1992, p.308-345.

${ }^{48}$ TAVARES, M. C. \& FIORI, J. L.. (Des) ajuste global e modernização conservadora. Rio de Janeiro: Paz e Terra, 1993.
} 
ascensão das chamadas interpretações "pós-modernas" na explicação das sociedades contemporâneas.

A comunidade docente formada entre duas culturas universitárias caracteriza-se por conservar aspectos múltiplos, anteriores ao processo de profissionalização da pósgraduação e, aos poucos, sintonizados às exigências dos novos tempos. O fato de ter se formado em pleno processo de transição da legislação educacional, lhe confere uma situação particular e conflituosa, na qual coabitam valores anteriores e posteriores à profissionalização $^{49}$.

Nesse sentido, faz-se necessário mais uma vez, frisar que se trata de uma comunidade docente formada entre a ditadura e a democracia, que, portanto, compartilhou experiências anteriores ao golpe de 1964, posteriores à decretação do AI-5 e durante o processo de transição política trançada que culminaria na Constituição de 1988. Em uma perspectiva política, seus membros atravessaram o período de "transição lenta, gradual e segura" e, ao mesmo tempo, tiveram uma participação nas lutas de resistência que combatiam a ditadura e procuravam viabilizar a sua superação.

Para além das circunstâncias factuais, trata-se de uma comunidade docente que conheceu um mundo anterior a financeirização da economia, quando o setor industrial ainda era hegemônico, e, além disso, viveu intensamente o período de transição marcado por profundas alterações político-econômicas que, segundo David Harvey, foram responsáveis por uma compressão demasiada do espaço-tempo nunca antes vista.

As transformações ocorridas no âmbito econômico durante a década de $1970 \mathrm{em}$ nível mundial ajudam a elucidar em que medida a formação e atuação dos professores universitários no Brasil estiveram submetidas à lógica da profissionalização. Esse novo regime de organização da carreira universitária, implementado a partir de 1968, precisa ser compreendido, portanto, como resultado de uma série de mudanças políticas e econômicas em escala global e no contexto de surgimento de uma nova divisão internacional do trabalho ${ }^{50}$. Além disso, uma série de profundas modificações no plano

\footnotetext{
${ }^{49}$ Para Marcos Napolitano, o avanço da pós-graduação contribuiu para ao surgimento de um novo tipo de intelectual: "O intelectual engajado, generalista, formado na órbita da Igreja Católica ou do Partido Comunista, atuando na imprensa diária ou associado à burocracia federal da cultura, estava sendo paulatinamente superado por um novo tipo de intelectual, especialista e profissionalizado". A comunidade docente pesquisada caracteriza-se justamente por desfrutar de experiências mistas e viver intensamente essa transição. Ver: NAPOLITANO, M. 1964: História do regime militar brasileiro. São Paulo: Contexto, 2014, p. 217.

50 “Entre 1970 e 1983, a fatia das exportações industriais globais que cabia ao Terceiro Mundo, até então estável em cerca de $5 \%$, mais que dobrou (Fröbel, Heinrichs, Kreye, 1986, p.200). Uma nova divisão
} 
tecnológico desembocaria na revolução microeletrônica ${ }^{51}$, que também teria um grande impacto nos sistemas de ensino. Tais mudanças, inclusive as novas exigências impostas pelo sistema produtivo industrial e pelo mercado internacional, afetariam a forma como o Estado e a iniciativa privada contemplariam as universidades, inaugurando uma nova Era de modelos avaliativos e exigências inéditas. Em muitos países, as chamadas políticas neoliberais, tais como aquelas praticadas por Reagan e Thatcher, não somente atuaram na desmontagem do Estado de bem-estar social, como também contribuíram para o corte de investimentos em educação pública ${ }^{52}$.

Nos termos utilizados por Hobsbawm, a comunidade docente em questão, conheceu tanto o boom de crescimento ocidental (1945-1975) quanto a crise econômica que se instalaria a partir do final desse ciclo de prosperidade. Mais que isso, trata-se de um grupo que acompanhou as mais rápidas transformações tecnológicas (revolução tecnológica) já vividas pela humanidade:

Quanto mais complexa a tecnologia envolvida, mais complexa a estrada que ia da descoberta ou invenção até a produção, e mais elaborado e dispendioso o processo de percorrê-la. 'Pesquisa e desenvolvimento' tornaram-se fundamentais para o crescimento econômico e, por esse motivo, reforçou-se a já enorme vantagem das 'economias de mercado desenvolvidas' sobre as demais. O 'país desenvolvido' típico tinha mais de mil cientistas e engenheiros para cada milhão de habitantes na década de 1970, mas o Brasil tinha cerca de 250, a índia 130, o Paquistão uns sessenta, o Quênia e a Nigéria cerca de trinta (UNESCO, 1985). Além disso, o processo de inovação passou a ser tão contínuo que os gastos com o desenvolvimento de novos produtos se tornaram uma parte cada vez maior e mais indispensável dos custos de produção ${ }^{53}$.

Um dos principais reflexos da chamada Era de Ouro nos países de capitalismo periférico foi a forte presença de multinacionais na região sudeste brasileira. Como constatou Hobsbawm, "para fugir das suas regiões de origem onde vigorava o pleno emprego, uma mão de obra bem paga e protegida, nada melhor do que 'os países em

internacional do trabalho, portanto, começou a solapar a antiga. (...) Grandes fabricantes de produtos eletrônicos começaram a globalizar-se a partir de meados da década de 1960. A linha de produção cruzava agora não hangares gigantescos num único local, mas o globo". HOBSBAWM, E. Era dos Extremos: o breve século XX (1914-1991). São Paulo: Cia das Letras, 1995, p. 275.

${ }^{51}$ Segundo Nicolau Sevcenko, "Tomando como base o ano de 1975, quando os circuitos integrados alcançaram o pico de 12 mil componentes, a Revolução Microeletrônica assumiu uma aceleração explosiva". Ver: SEVCENKO, N. A corrida para o século XXI - no loop da montanha-russa. São Paulo: Cia das Letras, 2001, p. 37.

${ }_{52}^{52}$ HOBSBAWM, E. Era dos extremos - o breve século XX (1914-1991). Op. cit., p.498-499.

${ }^{53}$ HOBSBAWM, E. Op. cit., p.261. 
desenvolvimento",54. A chegada das multinacionais contribuiu muito para alterar a físionomia de cidades como São Paulo e mudar definitivamente a composição demográfica do país. Nos anos 1970, o Brasil não era apenas um país em transição política trançada, mas atravessava um período no qual se impunha uma nova dinâmica populacional e transformações que alteraram radicalmente sua dinâmica cotidiana. Para Milton Santos, o momento correspondente à passagem das décadas de 1970 e 1980 no Brasil, é composto de sérias mudanças quantitativas e qualitativas quanto à organização demográfica do território:

Entre 1960 e 1980, a população vivendo nas cidades conhece aumento espetacular: cerca de 50 milhões de novos habitantes, isto é, um número quase igual à população total do país em 1950. Somente entre 1970 e 1980, incorpora-se ao contingente demográfico urbano uma massa de gente comparável ao que era a população total urbana de 1960. Os anos 60 marcam um significativo ponto de inflexão. Tanto no decênio entre 1940 e 1950, quanto entre 1950 e 1960, o aumento anual da população urbana era, em números absolutos, menor que o da população total do país. Nos anos 1960-1970, os dois se aproximavam. E, na década 1970-1980, o crescimento da população urbana já era maior que o da população total ${ }^{55}$.

Os anos 1970 do século passado também estiveram na mira de David Harvey que, na obra A Condição Pós-moderna, apresentou uma síntese precisa a respeito das mudanças ocorridas a partir de 1972 no plano econômico internacional. Para este autor, o início dos anos 1970 foi marcado pela passagem do modelo econômico fordistakeynesiano (1945-1973) para a hegemonia de um novo regime produtivo baseado na Acumulação Flexível. As alterações no plano econômico produziram resultados inovadores em diferentes contextos sociais, tendo inclusive, afetado o modo como as pessoas passaram a se relacionar com o tempo, dado o novo regime de "compressão do tempo-espaço na organização do capitalismo".

Somadas às questões econômicas, as mudanças no campo cultural ganham dialeticamente um contorno mais rico e contribuem enormemente para a compreensão de uma comunidade acadêmica em trânsito formada em um contexto de crítica radical à modernidade, particularmente à herança Iluminista e à razão moderna, forjada no período de ascensão do chamado "pós-modernismo"; ou, segundo as palavras de Fredric

\footnotetext{
${ }^{54}$ Idem, p. 276.

${ }^{55}$ SANTOS, M. A urbanização brasileira. São Paulo: Edusp, 2009, p.32.
} 
Jameson, momento em que a lógica cultural do capitalismo tardio passava a se impor no horizonte. Na definição crítica de Harvey:

Mas se, como insistem os pós-modernistas, não podemos aspirar a nenhuma representação unificada do mundo, nem retratá-lo como uma comunidade cheia de conexões e diferenciações, em vez de fragmentos em perpétua mudança, como poderíamos aspirar a agir corretamente diante do mundo? A resposta pós-moderna simples é a de que, como a representação e a ação coerentes são repressivas e ilusórias (e, portanto, fadadas a ser autodissolventes e autoderrotantes), sequer deveríamos tentar nos engajar em algum projeto global ${ }^{56}$.

A análise do processo de financeirização da economia global empreendida por Harvey permite uma compreensão ampla e profícua das mudanças promovidas desde o plano econômico e, até mesmo, as suas inter-relações, passando pelo cotidiano e pela produção cultural. Deste modo, o autor salienta como o novo padrão de acumulação capitalista influenciou a produção do conhecimento científico e, consequentemente, todos os aspectos da vida acadêmica:

O acesso ao conhecimento científico e técnico sempre teve importância na luta competitiva; mas, também aqui, podemos ver uma renovação de interesse e de ênfase, já que, num mundo de rápidas mudanças de gostos e necessidades e de sistemas de produção flexíveis (em oposição ao mundo relativamente estável do fordismo padronizado), o conhecimento da última técnica, do mais novo produto, da mais recente descoberta científica, implica a possibilidade de alcançar uma importante vantagem competitiva. O próprio saber se torna uma mercadoria-chave, a ser produzida e vendida a quem pagar mais, sob condições que são elas mesmas cada vez mais organizadas em bases competitivas. Universidades e institutos de pesquisa competem ferozmente por pessoal, bem como pela honra de patentear primeiro novas descobertas científicas (quem primeiro conseguir patentear o antídoto para o vírus da AIDS certamente terá bons lucros, como o reconheceu claramente o acordo entre pesquisadores norte americanos e o Instituto Pasteur francês sobre a partilha de informações e de direitos de patente). A produção organizada de conhecimento passou por notável expansão nas últimas décadas, ao mesmo tempo que assumiu cada vez mais um cunho comercial (como o provam as incômodas transições de muitos sistemas universitários do mundo capitalista avançado de guardiães do conhecimento e da sabedoria para produtores subordinados de conhecimento a soldo do capital corporativo) $)^{57}$.

\footnotetext{
${ }^{56}$ HARVEY, D. A Condição Pós-Moderna. São Paulo: Loyola, 1992, p.55.

${ }^{57}$ HARVEY, D. Op. Cit., p.151.
} 
Para além da pressão imposta pelos novos parâmetros internacionais, o Sistema Nacional de Pós-Graduação criado pelos militares foi uma resposta às exigências do modelo econômico conservador que o golpe de 1964 havia fixado. Isso não significa que o processo de implantação das propostas conservadoras elaboradas pelos militares tenham conquistado todos os objetivos propostos e esperados. Não se pode dar crédito também a interpretações rasteiras que tentam fixar como regra geral a capacidade das mudanças econômicas determinarem as atitudes dos sujeitos históricos em seu cotidiano. Mediações são necessárias, principalmente quando observada a maneira como os docentes enfrentaram a nova legislação e utilizaram-se dela para investir em propósitos autônomos, autênticos e que viabilizaram a formação de novas gerações de pós-graduandos também capazes de resistir ao processo de mercantilização da então Faculdade de Filosofia, Letras e Ciências Humanas. Como concluiu Renato Ortiz, na prática, a estrutura universitária de pesquisa criada pela ditadura brasileira não resistiu às fissuras infligidas pelo cotidiano:

A "escola paulista" de sociologia, personificada na figura de Florestan Fernandes, data dos anos de 1950. Nesse momento, outras disciplinas, como a antropologia, certamente existiam, mas apenas de forma incipiente, desenvolvendo-se em pontos distantes e desconectados do país e praticadas por um número bastante reduzido de pessoas (a ciência política não existia ainda como especialização). Não se pode esquecer que o desenvolvimento de uma rede universitária de ensino, até a reforma de 1968, era também limitado. Na verdade, a institucionalização das ciências sociais se consolida nos anos de 1970 e 1980 com a emergência de um sistema nacional de pós-graduação (mestrado e doutorado) apoiado pelas agências financiadoras federais (Capes, CNPq) e estaduais (Fapesp), panorama que torna o Brasil hoje um país relativamente "privilegiado" comparado a seus vizinhos, pois em nenhum deles houve um desenvolvimento tão intenso das redes universitárias de pesquisa. Contrariamente às ditaduras chilena, argentina, uruguaia, os militares brasileiros foram "modernizadores", isto é, impulsionaram o crescimento econômico nos marcos de uma política autoritária, o que teve consequências importantes na reestruturação da universidade ${ }^{58}$.

Walnice Nogueira Galvão escreveu na Revista Ensaios de Opinião uma crítica ao livro Tereza Batista Cansada de Guerra, do escritor Jorge Amado, originalmente publicada em 1975. No artigo intitulado “Amado: respeitoso, respeitável”, Galvão destacava o estreitamento da relação existente entre a obra literária e o mercado

\footnotetext{
${ }^{58}$ ORTIZ, R. “Estudos culturais”. Tempo Social, São Paulo, v. 16, n. 1, Jun. 2004, p. 119-127.
} 
editorial. Em 1973, a autora foi uma das primeiras a denunciar o processo de profissionalização dos escritores que, paralelamente a ampliação do poder econômico das editoras, passavam a estar preocupados com a conquista de um mercado literário e na fidelização de um público capaz de garantir a produção de best-sellers. Em dura crítica, a autora afirmava, entre outras coisas, que Jorge Amado abusava artificialmente do "aperfeiçoamento da mitologia baiana":

Em sociedades razoavelmente abertas ao debate cultural, o ingrediente progressista no best-seller, seja ele ficção escrita, história-emquadrinhos, é corrente, e pode ir até sua própria crítica. Quanto a nós, entra ano sai ano, aguarda-nos mais um romance de Jorge Amado, reiterando seu amaneiramento, apenas aguçando seus instrumentos para pior. Os livros são cada vez mais volumosos, o que lhes aumenta o preço e a decorrente quantia para o autor sobre o total da venda. Há, cada vez mais, trechos obviamente repetidos; percebe-se que são três ou quatro versões de um mesmo episódio para seleção e aperfeiçoamento num único, final, que nunca aparece; mas aparecem as três ou quatro versões escritas ao correr das teclas. Cada vez mais, há menor elaboração artística, a par da fórmula pessoal infalível que é o aperfeiçoamento da mitologia baiana: comida de dendê e cachaça, praias e coqueiros, candomblé e mulatas, pretos e saveiros, coronéis e prostitutas, sexo e violência ${ }^{59}$.

Curiosamente, os escritores brasileiros que sempre mantiveram uma forte relação com o Estado, inclusive baseada em vínculo empregatício, começaram a desfrutar nos anos 1970 da possibilidade de tornarem-se autônomos. Contudo, se o afastamento das garras estatais poderia significar fartos recursos financeiros, havia também a possibilidade de uma terrível cilada: a da aparente independência em relação ao mercado editorial. Como também alertava a Prof. ${ }^{a}$ Walnice Galvão, "se o escritor é comandado pelo gosto do mercado, sua obra não pode ir contra o gosto de mercado, nem como forma nem como ideias. Não pode ser nova, já nasce velha" ${ }^{\text {. }}$.

A profissionalização da carreira universitária, portanto, marchou vinculada ao avanço das novas regras de mercado no campo cultural ${ }^{61}$. Pari passo ao processo de

\footnotetext{
${ }^{59}$ GALVÃO, W. N. Saco de gatos: ensaios críticos. São Paulo: Duas Cidades, 1976, p.15-16.

${ }^{60}$ Idem, p. 13 .

${ }^{61}$ Segundo Heloisa Buarque de Hollanda, "a modernização, levada a toque de caixa, parece envolver o país numa 'atmosfera competente'. A tecnoburocracia desenvolve-se, sofisticando seus métodos e seu discurso, agora povoado de siglas, fórmulas, índices e expressões retiradas do eficiente vocabulário técnico-administrativo norte-americano. As comunicações são modernizadas e a indústria cultural se desenvolve no sentido do mercado da classe média. Proliferam as enciclopédias em fascículos, tipo Abril e congêneres, as coleções as mais variadas, do mundo animal à filosofia grega, da Bíblia às revistas especializadas. A música popular assiste à emergência de marchinhas exortativas e o sambão joia faz
} 
ampliação do sistema de pós-graduação caminhava o mercado editorial. Se em 1966 foram publicados 44 milhões de exemplares no Brasil, em 1980 já eram comercializados 245 milhões, cifra que chegaria a 330 milhões em $1995^{62}$. A comunidade docente, nesse sentido, acompanhou nos anos 1970 o avanço e a consolidação definitiva da indústria cultural e do mercado editorial no país:

Intervenção estatal nos sugere o reconhecimento de uma crescente tendência à articulação da produção cultural no Brasil. Coloca-se cada vez mais para o cinema, o teatro, as artes plásticas, a literatura, etc. a necessidade de uma organização 'madura', empresarial, adequada às condições de um capitalismo mais avançado, industrial, urbano, moderno, que, aos trancos e barrancos, vem constituindo-se no país. A conquista de mercado e a profissionalização apresentam-se como questões primordiais no próprio debate a cerca das funções sociais e políticas da cultura na sociedade brasileira. Entre os autores, nas diversas áreas, parece vingar a consciência de que as artes não são um campo 'isento', 'limpo', uma espécie de reduto intocado pelo circuito do dinheiro. O caráter de mercadoria do produto cultural torna-se um dado cada vez mais presente, a exigir da intelectualidade a reelaboração de táticas para lidar com seu trabalho, com o mercado, com o capital ${ }^{63}$.

Forjada em um intrincado contexto de transição, a comunidade docente pesquisada aos poucos deixou de contar em seu horizonte cultural com referências clássicas e tradicionais aprendidas nos bancos escolares, para viver um período mais sisudo, no qual era preciso avaliar as consequências do AI-5, a eclosão da luta armada e o avanço da repressão. Nesse contexto, a comunidade docente passou a incorporar também as críticas que eram forjadas contra o populismo de Estado, partidos e sindicatos e ao nacionalismo que se consolidariam em propostas de pesquisas organizadas pelo CEBRAP e pelo CEDEC. Para quem permaneceu na universidade,

fundo musical para as novas churrascarias. As artes plásticas tornaram-se um rentável negócio, concorrendo com a bolsa de valores, no teatro as grandes produções empresariais dominam a cena aberta, e o cinema começa a colocar-se a necessidade de assumir, definitivamente, sua maturidade industrial". Ver: BUARQUE DE HOLLANDA, H. \& GONÇALVES, M. A.. "A Ficção da realidade brasileira". In: NOVAES, A. (org.) Anos 70: ainda sob a tempestade. Rio de Janeiro: Aeroplano: Editora Senac Rio, 2005 , p.99.

${ }^{62}$ PELLEGRINI, T. “A cultura brasileira em tempo de mídia e mercado”. Horizontes (Bragança Paulista), Bragança Paulista, SP, v. 15, p. 325-335, 1997. A Prof. ' Tânia Pellegrini aponta para o casamento entre mídia e mercado como uma novidade significativa no período. Como caso emblemático, cita a publicação da lista de livros mais vendidos no mercado feita pela Revista Veja, iniciada em 1973. Ver também: PELLEGRINI, T. Aspectos da produção cultural brasileira contemporânea. Critica Marxista, São Paulo, v. 1, n.2, p. 69-91, 1995.

${ }^{63}$ BUARQUE DE HOLLANDA, H. \& GONÇALVES, M. A.. "A Ficção da realidade brasileira”. Op. cit., p.112. 
como docente ou discente, era preciso reunir os cacos e manter os trabalhos de pesquisa e ensino, adotando novas estratégias de atuação.

Os professores pertencentes à comunidade docente estudada acompanharam o processo de estreitamento dos laços do Estado com as universidades durante os anos 1970. Paradoxalmente, os militares implantaram uma carreira cada vez mais atraente para intelectuais que optavam pela vida universitária. Se a remuneração e as condições de trabalho não eram as mais satisfatórias no começo desse processo, o número crescente de oportunidades, a estabilidade e a possibilidade de continuar pesquisando e progredindo na carreira, podem ter feito a diferença. Segundo Rodrigo Pato Sá Motta, "modernização conservadora autoritária é o termo adequado para expressar a reforma universitária da ditadura" que, em números, significou:

Em 1964 havia 23 cursos de pós-graduação no Brasil, enquanto em 1974 eles passaram a quatrocentos; o número de estudantes universitários subiu de 140 mil em 1964 para 1 milhão e 300 mil em 1979; as bolsas de pós-graduação financiadas pelas agências federais (Capes e CNPq) passaram de aproximadamente 1000 em 1964 para cerca de 10 mil em $1976^{64}$.

O contexto de transição implicava aprender a lidar com situações muito diferentes e ambíguas. O boom referente à produção, distribuição e consumo de bens culturais, acarretou novos desafios aos intelectuais. Dentre eles, era preciso palmilhar com cuidado novos terrenos que apresentavam paisagens e caminhos imprecisos que poderiam se desdobrar, ao mesmo tempo, tanto em oportunidades quanto em adversidades $^{65}$. As novas circunstâncias implicavam em desvendar as relações entre a política autoritária e a cultura. Afinal, qual era o significado de estar sob um Estado autoritário que, ao mesmo tempo, coibia fortemente a atividade intelectual de resistência e investia na estruturação dos programas de pós-graduação nas universidades ${ }^{66}$ ?

\footnotetext{
${ }^{64}$ MOTTA, R. P. S. "A modernização autoritário-conservadora nas universidades". In: AARÃO REIS FILHO, D. \& RIDENTI, M. \& MOTTA, R. P. S. (orgs.) A ditadura que mudou o Brasil: 50 Anos do golpe de 1964. Rio de Janeiro: Zahar, 2014, p.57.

${ }^{65}$ Segundo Renato Ortiz, "os dados relativos à imprensa exprimem claramente a expansão do volume do mercado consumidor. Em 1960 a tiragem dos periódicos era de 3951584 e de não diários, de 4213 802; em 1976 ela passa para 1272901104 diários e 149415690 não diários. Apesar do número de jornais ter permanecido praticamente o mesmo, o que em si já é um indicador do processo de monopolização dos meios de comunicação de massa, e mesmo sem levar-se em conta o aumento populacional, pode-se obervar que o aumento do público consumidor é bastante grande. Ver: ORTIZ, R. Cultura Brasileira e Identidade Nacional. São Paulo: Brasiliense, 2006, p. 83-84.

${ }^{66}$ A relação entre o Estado autoritário e a cultura mobilizou a atenção de intelectuais tais como Gabriel Cohn, Octávio Ianni e Renato Ortiz. Ver: ORTIZ, R. "Estado autoritário e cultura”. In: ORTIZ, R. Cultura
} 
Walnice Galvão, tal como Bosi, procurou no início dos anos 1980, apresentar as principais características das mudanças em curso na universidade brasileira. Ao elaborar uma crítica à nova cultura universitária, a autora utilizou como referência, ainda que oculta, a transferência da Faculdade de Filosofia da USP para a cidade universitária. É, portanto, a partir da sua experiência e das suas lembranças enquanto aluna e docente na Faculdade de Filosofia da Rua Maria Antônia, que se basearam os seus argumentos contra a "fragmentação e a compartimentação" do saber. Entre as conclusões um tanto melancólicas do seu ensaio, destacou-se aquela na qual a autora afirma restar apenas a lembrança da Maria Antônia e "a nostalgia do ideal de universidade":

Dentro da universidade, e sem falar no ensino, a pesquisa quase desapareceu. Quem decide a respeito das pesquisas a serem executadas pelo pessoal da universidade são outras instituições de financiamento à pesquisa. A universidade perdeu o poder sobre a pesquisa, assim como perdeu o poder sobre o vestibular. Outro componente vital para a universidade, o princípio da associação, cedeu lugar à fragmentação. A maneira como o campus é concebido prédios de faculdades isolados por grandes distâncias - impedem que os colegas se encontrem. Se não foi de propósito, a reforma arquitetônica que impôs o campus de modelo norte-americano foi muito a propósito. A universidade se atomizou e deixou de ser um lugar de convívio. Cada um tem seu projeto individual e trabalha nele sozinho, com graves perdas para si mesmo e para os outros. Resta a nostalgia do ideal de universidade, um lugar onde não há compartimentação do saber, onde se convive e se debate entre pares ${ }^{\prime 67}$.

\subsection{A presença da Maria Antônia na memória coletiva da comunidade docente.}

Essa rua não é um lugar - é uma época. Microcosmo político, sentimental, intelectual, deu o diagnóstico de uma história ${ }^{68}$.

Como visto anteriormente, a saída da Faculdade de Filosofia da USP situada à Rua Maria Antônia e a vinda para a cidade universitária esteve atrelada a processos políticos, econômicos e culturais mais amplos. A longa travessia da ditadura para a

Brasileira e Identidade Nacional. Op. cit., p.79-89. Alfredo Bosi examinou especificamente a chamada cultura universitária, destacando a posição crítica dos intelectuais diante da indústria cultural. BOSI, A. "Cultura brasileira e culturas brasileiras". In: BOSI, Alfredo. Dialética da colonização. Op. cit..

67 GALVÃO, W. N. "Finalmente: ensino pago para todos". In: Gatos de outro saco. São Paulo: Brasiliense, 1981, p. 187.

${ }^{68}$ MATOS, O. F. C. Memorial. São Paulo: FFLCH-USP, 1996, p.22. 
democracia que acompanhou os docentes pertencentes à comunidade universitária estudada delimitou experiências marcantes e comuns ao grupo: a participação no movimento estudantil nos anos 1960; a "Batalha da Maria Antônia" que culminou com a saída da Faculdade de Filosofia da Rua Maria Antônia, no centro, e a ida para a cidade universitária no Butantã; o antigo regime de cátedras e a passagem às novas determinações da Lei 5540/68; o trágico episódio do assassinato de Vladimir Herzog, a posterior fundação da ADUSP em 1976 e a publicação do Livro Negro da USP, a publicação da chamada Lista dos Improdutivos pela Folha de São Paulo em 1986; a aprovação da autonomia universitária em 1988; as discussões em torno da divisão da FFLCH-USP na década de 1990.

Espremida entre dois cenários políticos opostos e duas culturas universitárias, a comunidade docente conserva em suas memórias as experiências individuais que mencionam o medo, a censura, as cassações dos professores, o fechamento do edifício que abrigava a Faculdade de Filosofia na Rua Maria Antônia, a prisão, a tortura, o "desterro" e o "exílio" na cidade universitária. Nesse sentido, as entrevistas de história oral de vida possibilitaram avaliar múltiplas relações entre as memórias individuais e as principais referências presentes na memória coletiva da comunidade docente estudada.

O conjunto das entrevistas permitiu analisar ainda as interfaces e negociações estabelecidas pelos colaboradores, bem como os silêncios e interditos. Como a memória coletiva consiste em um território permanentemente disputado e atrelado às memórias individuais, foi fundamental compreender a maneira como ambas se alimentaram mutuamente e foram palco de negociações, crises e acordos que forjam elementos essenciais para a construção de novas interpretações no tempo presente ${ }^{69}$.

Foram investigados os traços mais marcantes presentes na memória coletiva da comunidade docente e como as memórias individuais dos professores negociaram, disputaram e compartilharam os episódios ocorridos. Nesse sentido, algumas balizas foram extremamente significativas. A Faculdade de Filosofia da Rua Maria Antônia é um dos principais símbolos que definem a memória coletiva da comunidade docente estudada. $\mathrm{O}$ encerramento abrupto de suas atividades e a transferência para a cidade universitária adquiriu múltiplas interpretações. A tese mais recorrente entre alguns docentes é a de que a ida para o bairro do Butantã era parte de um projeto arquitetado

${ }^{69}$ POLLAK, M. Op. cit.. 
pela ditadura para desarticular uma proposta de formação intelectual e política que estava inserida em um contexto de diálogo com a comunidade no centro da cidade.

A transferência de seus cursos para a cidade universitária é interpretada como um ato político que promoveu o desterro da Faculdade de Filosofia da região central de São Paulo; um exílio permanente. Para os docentes entrevistados que estudaram e/ou deram aulas na Rua Maria Antônia, a Faculdade de Filosofia permitia o acesso a uma formação crítica e diferenciada porque estava inserida em um contexto político e cultural extremamente importante do circuito paulistano e, ao mesmo tempo, atenta a questões sociais e que diziam respeito ao espaço público no âmbito nacional.

\subsubsection{A formação básica.}

Os docentes foram enfáticos ao destacarem nas entrevistas a importância da escola primária e secundária onde estudaram. Todos os colaboradores, sem exceção, mencionaram que os bancos escolares por onde passaram tiveram a capacidade de inseri-los na esfera da cultura formal, que lhes proporcionaria condições plenas para dar continuidade aos estudos universitários. A fase inicial de estudos da comunidade pesquisada transcorreu em sua maioria em colégios públicos, contudo, alguns professores se formaram em escolas religiosas de origem católica.

"Cresci em uma escola onde os valores eram laicos, iluministas e republicanos. E depois fui reencontrar isso na Universidade de São Paulo”, afirmou Matos em relação à importância da escola pública em sua formação intelectual. Sandra Vasconcelos também foi muito enfática ao falar sobre a sua relação com a escola pública:

Eu sou um artigo raro nos dias de hoje, mas não na minha geração. Sou uma aluna de escola pública. Fiz toda a minha formação, aquilo que a gente chamava de escola primária e secundária em escola pública.

Um dos traços característicos da comunidade docente estudada diz respeito à relação estabelecida com as escolas públicas estaduais. Para muitos ela representava a única possibilidade de acesso à cultura letrada. A maioria dos colaboradores aprendeu desde muito cedo a compreender as especificidades e o significado da educação básica 
pública e gratuita na formação de suas concepções sobre a sociedade brasileira e o regime republicano. Alessandri Carlos mencionou os anos passados no Colégio de Aplicação (USP) e fez questão de ressaltar a capacidade que essa escola teve de inseri-la em um universo cultural que ela desconhecia, preparando-a para o ensino superior:

No Colégio de Aplicação eu me deparei com outro tipo de estudo, com outra proposta pedagógica. Eu comecei, inclusive, a trabalhar imediatamente com os professores de teatro. Fomos até escrever uma peça de teatro baseada no livro do Campos de Carvalho, que era um autor que poucos liam na época. No colégio, me deparei com o ensino de francês, de inglês, coisa que não fazia muito parte dessa vivência.

Outro colaborador que também destacou a importância de sua passagem em escolas públicas foi Messias da Costa:

No início dos anos 1960 a minha família migrou para Santos porque uma parte dos parentes da minha mãe já morava nessa cidade. Ainda no interior do Paraná fiz o primário na escola pública. Depois, em Santos, cursei o Clássico quando podíamos optar pelos cursos Científico, Clássico ou a Escola Normal. Fiz o Clássico no Colégio Canadá porque já tinha uma predileção pela área de ciências humanas. Trata-se de um colégio histórico em Santos, com uma presença muito bonita na trajetória do ensino médio público do Estado de São Paulo. Ele se equipara ao famoso Colégio de Aplicação de São Paulo e tinha um ambiente muito interessante.

Janine Ribeiro também mencionou a formação obtida em colégios públicos. Além disso, lembra com muita atenção dos professores e do aprendizado desfrutado na escola pública:

Estudei sempre em colégio público e, uma boa parte do tempo, no Alberto Levy. Fiz o ginásio e depois o clássico com professores muito bons; em latim e português, tive a Professora Ana Lia de Almeida Prado, que hoje é professora de grego na USP. Em filosofia, tive aulas com Marilena Chauí, que estava começando a lecionar. Tivemos outros professores que eram muito bons em termos escolares, inclusive de francês e outras matérias. Na época o ensino público era ótimo. Prestei vestibular para filosofia e para cinema na recém-criada Escola de Comunicações Culturais, atualmente Escola de Comunicações e Artes (ECA-USP). Como passei em primeiro lugar em Filosofia na USP, onde minha então namorada foi a segunda colocada, pensei que deveria ser este o meu rumo. Não cheguei a me matricular na ECA. 
"Estudar e estar na escola sempre foram coisas muito valorizadas em casa. Fiz o primário em uma escola privada, mas depois realizei o ginásio e estudei sempre em escolas públicas. Até porque a escola pública era mais valorizada", comentou Adorno a respeito da sua formação básica. Além disso, acrescentou o professor: "As escolas privadas que eram valorizadas eram as de classe média alta e a gente nunca imaginava poder pertencer a elas".

Dentre os docentes que tiveram sua formação no ensino básico em escolas religiosas está Janice Theodoro: “Como a minha família era católica estudei em um colégio religioso chamado Rainha da Paz, de irmãs dominicanas. Creio que este convívio definiu as marcas da minha formação", comentou a professora. Os valores humanistas transmitidos pela experiência desfrutada junto às freiras dominicanas, segundo Theodoro da Silva, são base para a sua atuação intelectual no presente: "Diria que a minha formação é marcada por uma tradição humanista e, mais especialmente, por uma tradição dominicana à moda brasileira".

Albuquerque teve uma formação marcada pela sua participação no movimento estudantil católico e, portanto, inserida em princípios progressistas que defendiam a organização de projetos sociais, principalmente voltados para a educação:

No Rio de Janeiro estudei em um colégio de padres voltados para uma coisa bem social, era um colégio bastante simples. Depois estudei em um colégio de classe média, católico também. Depois estudei no Colégio Pedro II que é uma escola pública federal e, mediante concurso, fiz o colegial lá. Nessa época eu me envolvi com a Juventude Estudantil Católica e, depois, já na universidade cursando Filosofia, fiz parte da Juventude Universitária Católica (JUC) que foi uma das origens da Ação Popular (AP). Tive um papel bastante marcante de liderança na minha faculdade, fui membro do Conselho, presidente do Diretório, e elegi meu sucessor. Mas nunca me filiei à Ação Popular, mesmo naquela época.

Moisés também dedicou passagens importantes da sua entrevista falando a respeito dos momentos em que iniciou a sua atividade política no movimento estudantil, quando também estudava em escola pública. A atuação de Moisés no movimento estudantil foi originária de uma simbiose muito marcante no período: toda a sua formação básica foi feita em escola pública, inclusive o secundário foi cursado no Culto a Ciência em Campinas e, nesse contexto, foi presidente da União Campineira dos Estudantes Secundaristas entre 1961 e 1962 e, em seguida, presidente da UPES (União 
Paulista dos Estudantes Secundaristas), posição que o levaria para a capital. Toda a sua militância estudantil estava atrelada aos princípios defendidos pela juventude católica, na época, fortemente voltada para a atuação junto às comunidades mais necessitadas:

A origem da minha militância era católica, pertencia a Juventude
Estudantil Católica que, nessa época, era parte da Ação Católica. Ela
teve uma importância muito grande no Brasil nos anos que
antecederam a eleição do Papa João XXIII na igreja, o Concílio
Vaticano II e também uma encíclica que o Papa fez muito voltada para
a questão social que era a Mater et Magistra. A Ação Católica
brasileira sob esse influxo teve nessa fase grande influência de Don
Elder Câmara. A Ação Católica estava, portanto, em um momento de
muita mobilização e no meio estudantil era muito forte. Assim nossa
militância tinha o sentido católico e cristão, mas o veio mais forte era
de que os cristãos deveriam atuar na vida pública. Havia toda uma
formulação em torno do conceito de bem comum. Acho que não é
pouca coisa, que não é irrelevante porque teve o papel de agregar e
articular muitos jovens.

As lembranças em relação à escola pública e a valorização dos professores e da educação recebida fortalecem os laços identitários que dão sentido à comunidade docente. A continuidade das carreiras estabelecidas entre espaços públicos pode ter contribuído significativamente para a costura de um compromisso com a "coisa pública”. Esse vínculo ultrapassou os limites impostos pelas políticas estatizantes e fiéis ao status quo. Afinal, a estima pelo bem público não os impediu de elaborar uma crítica contra o Estado, o populismo e suas práticas autoritárias ${ }^{70}$.

Alguns narradores fizeram referência às escolas por onde passaram com um apreço muito especial. É necessário levar em consideração que as interpretações em relação ao estudo primário e secundário elaboradas pelos docentes foram influenciadas, em grande medida, pela reconstrução empreendida pela memória no tempo. Através do conhecimento e da formação obtida na Faculdade de Filosofia, os estudos na infância e adolescência ganham um novo sentido. Para além da perspectiva nostálgica, no entanto, a escola pública está presente na memória coletiva da comunidade docente como um ethos que, para a maioria, foi decisivo. Afinal, foi através da escola que tiveram acesso ao conhecimento formal de qualidade e vislumbraram a possibilidade concreta de continuação dos estudos na universidade.

\footnotetext{
70 Para Saviani, entendemos por educação pública quando o sentido de "público", "perde sua característica estatal, a contaminação da fé servil no Estado para recuperar sua raiz etimológica, isto é, popular”. In: SAVIANI. D. Ensino Público e algumas falas sobre universidade. Op. cit., p.24.
} 


\subsubsection{O contexto sociocultural e político.}

Entretanto, para surpresa de todos, a presença cultural da esquerda não foi liquidada naquela data, e mais, de lá para cá não parou de crescer. A sua produção é de qualidade notável nalguns campos, e é dominante. Apesar da ditadura da direita há relativa hegemonia cultural da esquerda no país. Pode ser vista nas livrarias de São Paulo e Rio, cheias de marxismo, nas estreias teatrais, incrivelmente festivas e febris, às vezes ameaçadas de invasão policial, na movimentação estudantil ou nas proclamações do clero avançado. Em suma, nos santuários da cultura burguesa a esquerda dá o tom. Esta anomalia que agora periclita, quando a ditadura decretou penas pesadíssimas para a propaganda do socialismo - é o traço mais visível do panorama cultural brasileiro entre 1964 e 1969. Assinala, além de luta, um compromisso $^{71}$.

O que é o romantismo? Enigma aparentemente indecifrável, o fato romântico parece desafiar a análise, não só porque a veracidade perabundante resiste às tentativas de redução a um denominador comum, mas também e sobretudo pelo seu caráter contraditório, sua natureza de coincidentia oppositorum: simultânea (ou alternadamente) revolucionário e contra revolucionário, individualista e comunitário, cosmopolita e nacionalista, realista e fantástico, retrógrado e utopista, revoltado e melancólico, democrático e aristocrático, ativista e contemplativo, republicano e monarquista, vermelho e branco, místico e sensual. Tais contradições permeiam não só o fenômeno romântico no seu conjunto, mas a vida e a obra de um único mesmo autor, e por vezes um único e mesmo texto ${ }^{72}$.

O compromisso em relação ao bem público e a formação humanista expresso pelos docentes nas entrevistas em relação à escola, veio à tona atrelado a um contexto de grande valorização no campo cultural dos temas românticos e revolucionários, através dos quais se articularam outros valores extremamente robustos para esses intelectuais. Esse potente ingrediente chamado romantismo revolucionário, nas palavras de Michael Löwy e Luisa Passerini, trazia ainda em sua essência "um protesto cultural contra os fundamentos da civilização industrial/capitalista moderna, seu produtivismo e seu consumismo e uma associação singular única e sem gênero, entre subjetividade, desejo e utopia",73.

\footnotetext{
${ }^{71}$ SCHWARZ, R. Cultura e política, 1964-1969. São Paulo: Paz e Terra, 2009, p.7-8.

${ }^{72}$ LÖWY, M. \& SAYRE, R. Revolta e Melancolia: o romantismo na contramão da modernidade. Petrópolis: Vozes, 1995, p.9.

${ }^{73}$ LÖWY, M. "O Romantismo revolucionário de Maio de 1968". Revista Espaço Acadêmico, №. 84, Maio de 2008. Ver: http://www.espacoacademico.com.br/084/84esp_lowyp.htm. Consultado em 14 jan.
} 
As experiências vividas pelos docentes nos anos 1960 e 1970 têm em comum a superexposição em relação a questões próprias ao desenvolvimento de um imaginário romântico e revolucionário ${ }^{74}$. A essa convivência conjugava-se uma preocupação dos intelectuais em refletir e narrar sobre o tempo histórico adjacente:

São escritores veteranos que vão lograr maior repercussão expressando as dificuldades desse novo momento. Antonio Callado e Érico Verissimo ratificam suas preocupações com o relato ficcional voltado para a história e publicam, após Quarup e Sr. Embaixador, romances marcantes da década de 60, Incidente em Antares e Bar D. Juan, ambos de 1971. A literatura assume, já nesse início de década, através de dois escritores 'clássicos' do romance político recente, um papel que, se não chega a constituir uma novidade, vai estar reforçado e revalorizado pelas circunstâncias políticas e culturais do país: contar a história, testemunhar, colar-se ao real imediato ${ }^{75}$.

A comunidade docente acompanhou de perto o avanço e o refluxo dos projetos românticos e revolucionários avaliados por Marcelo Ridenti. Tratou-se de um período turbulento para os intelectuais, retratado com densidade pelas obras de Antonio Callado, balizas singulares para a compreensão desse contexto: os romances Quarup, de 1967, passando por Bar Don Juan, de 1971 e chegando a Reflexos do Baile, de 1976. As personagens de Callado, de algum modo, acompanharam e vivenciaram os diferentes conflitos e dramas intelectuais de uma época: Pe. Nando se transformara em um guerrilheiro, a boemia militante reunida no Don Juan tornara-se melancólica e, por fim, delineava-se um intrincado papel para o escritor/intelectual de Reflexos do Baile no entreato das correspondências trocadas durante os anos de chumbo ${ }^{76}$.

As atividades desenvolvidas pelo movimento estudantil e pelas novas gerações de ingressantes na Maria Antônia contribuíram para a aproximação entre esta Faculdade de

\footnotetext{
2014.

${ }^{74}$ Nos dizeres de Marcelo Ridenti: Pode-se pensar no romantismo revolucionário florescente no Brasil nos anos 60 e início dos 70 como um conjunto diferenciado, composto por diversos matizes intermediários entre as utopias de povo-nação e as de inspiração social, na formulação de Saliba, ou entre os romantismos revolucionários jacobino-democráticos, populistas, utópico humanistas, libertários e marxistas. O florescimento das mais variadas formas de romantismo revolucionário nos anos 60 só pode ser compreendido dentro da temporalidade em que ele se desenvolveu, e posteriormente, refluiu. RIDENTI, M. Em Busca do Povo Brasileiro - artistas da revolução, do CPC à era da TV. Rio de Janeiro: Record, 2000, p.33.

${ }^{75}$ BUARQUE DE HOLLANDA, H. \& GONÇALVES, M. A.. "A Ficção da realidade brasileira”. Op. cit., p. 101.

76 “O livro revela o desencanto de Callado com sua breve e frustrada militância na resistência guerrilheira articulada por Leonel Brizola, e também com o esquerdismo de seus amigos, que se reuniam na época no restaurante Antonio's, no Rio de Janeiro, como Callado afirmou na entrevista que me concedeu". Ver: RIDENTI, M. Em Busca do Povo Brasileiro - artistas da revolução, do CPC à era da TV. Op. cit., p. 151.
} 
Filosofia e as intensas atividades político-culturais circunvizinhas. As menções feitas em relação ao cenário cultural de uma Paulicéia envolvida em diversos movimentos que chamavam a atenção para a necessidade de criação de uma produção autêntica, geralmente estão imbricadas às lembranças de um intenso convívio estudantil nos períodos mais difíceis da Maria Antônia.

Alguns docentes enfatizaram a importância que o contexto das artes dos anos 1960 teve sobre a sua formação intelectual. Matos relatou que seu ingresso na Maria Antônia se deu aos 17 anos e, como num rito de iniciação, passou a ter acesso a uma intensa vida cultural:

Além disso, conheci pessoas de várias idades e iniciava uma vida cultural que não tinha antes. Próximo à Maria Antônia havia o Cine Bijou, o Teatro Municipal, o Teatro de Arena, a Biblioteca Municipal, as livrarias, era uma vida ligada à cultura. E, na época, a esquerda era a vanguarda cultural.

Nas vizinhanças da Rua Maria Antônia, como citou Matos, havia uma ampla oferta cultural pautada em elementos românticos e revolucionários. Espaços como o Teatro de Arena, o Bar Redondo, o Cine Bijou, o Restaurante A. Baiúca, o Restaurante Gigetto, a Biblioteca Municipal Mário de Andrade e a própria Faculdade de Filosofia, cultivavam um intenso diálogo com a comunidade e contribuíam para a formação política dos intelectuais e cidadãos que por ali circulavam ${ }^{77}$.

O Grêmio da velha Faculdade de Filosofia também foi lembrado por Benjamin Abdala como um espaço de liberdade e de formação cultural e política:

O grêmio desenvolvia várias atividades, incluindo teatro e cinema. O Renato Tapajós era aluno de Ciências Sociais e realizou alguns curtasmetragens sobre as atividades do próprio grêmio. Sei disso por que participei de alguns curtas. Tenho vontade de fazer uma edição, tipo fac-similar, com pequenos depoimentos dos atores que atuaram nessa época, para mostrar justamente como se fazia política naquele momento. Algo sem nostalgia.

\footnotetext{
${ }^{77}$ Izaías Almada, escritor, dramaturgo e ator do Teatro de Arena entre 1965 e 1968, na época também estudante do curso de Ciências Sociais na Maria Antônia, descreveu o cenário cultural no qual os estudantes da USP estavam inseridos: "A verdade é que para o pequeno espaço da Rua Teodoro Baima em frente ao Bar Redondo, junto à Praça Roosevelt, convergiram inúmeras personalidades da cultura e das artes brasileiras na década de 1960 em São Paulo. Além de apresentar as peças encenadas de terça a domingo pelo elenco principal, o teatro permanecia aberto durante toda a semana com inúmeras atividades: peças alternativas, shows de música popular, teatro infantil, corais, palestras, seminários, encontros políticos, assembleias de várias categorias profissionais". ALMADA, I. Teatro de Arena - uma estética de resistência. São Paulo: Boitempo, 2004, p.97.
} 
As referências presentes nas memórias docentes sobre a vivência universitária na Maria Antônia remontam as ações práticas fomentadas pelo movimento estudantil na área cultural. Segundo Nitrini, os centros acadêmicos eram responsáveis por contribuir para uma formação intelectual e política dos universitários porque eram capazes também de fomentar articulações entre teoria e prática educacional:

No terceiro ano da Faculdade fui fazer parte do Centro Acadêmico de Letras (CAEL). Naquela época se escrevia com um "L" só, hoje tem dois porque é Centro Acadêmico de Letras e Linguística (CAELL). Eu não fazia parte da diretoria, a diretoria era composta pelo José Miguel Wisnik, Lígia Chiappini Morais Leite, o Gilson Rampazzo, Akira Osakabe... A maioria viria a ser professor da USP, o Akira foi para a Unicamp. Lembro-me que eu e o Zenir Campos Reis, que era um colega de letras clássicas, e também veio a ser docente da USP, fomos encarregados de nos ocuparmos do departamento de orientação de estudos. Havia vários departamentos, de teatro, de cinema, etc. Sei que criaram um departamento de orientação de estudos e nós ficamos responsáveis por esse departamento. E o que nós fazíamos? As turmas eram menores, porque não havia preenchimento de vagas naquela época. Cada habilitação oferecia entre 15 e 20 vagas, se não me engano. Nós nos reuníamos para levantarmos as dificuldades que os ingressantes tinham e íamos atrás de soluções. Em geral, os estudantes tinham dificuldade em latim, sobretudo, em versão, e em análise sintática. O CAEL organizava grupos de estudos, que eram coordenados pelo Zenir e por mim. No fundo, nós dávamos uma espécie de aulas de reforço. O Zenir encarregava-se da análise sintática e eu, do latim.

Os grupos de estudos, as monitorias e as "aulas de reforço" foram mencionadas por Nitrini para ressaltar as preocupações de uma comunidade estudantil em corrigir a defasagem educacional dos colegas que chegavam. O objetivo era nivelar as condições de aprendizagem. Nesse sentido, a atuação discente empreendida pelo Centro Acadêmico de Letras foi lembrada como parte integrante da formação de uma geração inteira de professores que viria a dar aulas em universidades públicas, inclusive na própria Faculdade de Filosofia.

Durante a entrevista, Matos recordou os momentos que antecederam o fechamento da Maria Antônia, destacando mais uma vez o papel que o movimento estudantil desempenhava em ações voltadas para a formação cultural e política dos alunos:

Antes dos ataques à Faculdade de Filosofia, nós ocupamos o prédio e organizamos uma série de atividades. Havia o setor de jornalismo, de 
alimentação, bem como o setor que cuidava da biblioteca e outro que cuidava do cinema. Eu era considerada "alienada" porque gostava de cuidar da área de cinema. Nesse momento passamos no cineclube filmes de Eisenstein, como A Greve, do Rossellini, Roma, Cidade Aberta e, ainda, Rocco e Seus Irmãos de Visconti. Havia também o setor de imprensa e um grupo responsável pelos cursos paralelos. Então, os cursos que não estavam ocorrendo normalmente, eram substituídos por professores convidados para dar uma aula magna. Aprendi Marx em uma dessas aulas públicas dadas na Maria Antônia pelo Prof. José Arthur Giannotti.

As lembranças em relação à Maria Antônia sempre remetem à forte presença dos estudantes no movimento estudantil e no cotidiano da vida universitária. Os docentes que lá se formaram fizeram questão de frisar a importância que esse convívio acadêmico teve enquanto um ambiente que favorecia o aprendizado profissional e a formação política. Como as ações políticas convencionais estavam proibidas nos espaços públicos, a Faculdade de Filosofia tornava-se um importante local de encontro e um centro difusor de conhecimento que dialogava com um público mais amplo.

Muitos estudantes que haviam acabado o secundário (ensino médio) procuravam pelo cursinho que era dirigido pelo Grêmio da Faculdade de Filosofia. Os professores que ministravam as aulas preparando os alunos para os vestibulares eram os próprios universitários que eram remunerados com uma parte das mensalidades, enquanto a outra era utilizada pelo Grêmio para suas atividades. Nitrini recordou suas atividades como professora no pré-vestibular, destacando o quanto o convívio universitário agregava conhecimento aos estudantes que estavam procurando uma oportunidade no ensino superior e para aqueles que já estavam integrados à vida acadêmica:

Além dessas atividades, havia, evidentemente, as discussões políticas sobre a situação, a ditadura, a falta de democracia, as conversas com os professores e a participação em passeatas. Outra coisa que também era muito importante na nossa época era o Grêmio da USP, o Grêmio tinha um cursinho que funcionava em dois ou três lugares, nas imediações da Maria Antônia. Para darmos aula nesse cursinho tínhamos que passar por um processo seletivo concorrido. Essa experiência foi muito importante para a nossa formação, porque a gente estudava, dava as aulas, estava em um meio muito atuante entre os alunos que faziam seus cursos extensivos, ou semi-intensivos ou intensivos. Lembro-me que, muitas vezes, quando havia passeatas, nós que éramos professores dos cursinhos também íamos acompanhados dos alunos. Então todo esse contexto, toda essa vivência, foi muito importante para a formação da nossa geração. Claro que a época propiciava tudo aquilo, muita solidariedade entre estudantes, entre professores e entre estudantes e professores. 
A Faculdade de Filosofia sempre foi mencionada nas entrevistas como um centro de convergência política na qual predominavam as legendas de esquerda e as organizações católicas progressistas. Essa atmosfera de resistência à ditadura se conjugava ao trabalho acadêmico, na medida em que professores e alunos transferiam para as pesquisas hipóteses e objetivos de trabalho sugeridos nesse cotidiano. Ao refletirem sobre a produção acadêmica desenvolvida entre os anos 1970 e início dos 1980, alguns docentes mencionaram a prática de associar os objetos e hipóteses de pesquisa à necessidade de se construir uma reflexão a respeito do autoritarismo e de como superá-lo. Janice Theodoro relatou a importância que a questão do Estado teve para a sua produção intelectual e o quanto ela estava atrelada a ideia de contribuir para a construção de um projeto político e social alternativo para o país:

Se tivesse que pensar a questão da minha produção. É esta uma questão essencial. O que eu escrevi? Escrevi minha dissertação de mestrado sobre o Rio Grande do Norte. É uma tese que tem uma marca política clara. Naquela época queria encontrar o que todo mundo procurava, aquilo que era específico do Brasil... Para se fazer a revolução. Então comecei querendo estudar o movimento messiânico dos fanáticos da Serra João do Vale ${ }^{78}$, no Rio Grande do Norte. Mas esse era um tema muito perigoso para estudar. Acabei estudando um periódico do Rio Grande do Norte e fiz uma análise do jornal. O subtítulo do livro é: raízes da ideologia do planejamento ${ }^{79}$. Na verdade, o que essa geração tinha na cabeça? A ideia de que para o Brasil sair do impasse em que vivia era necessário você ter um projeto e planejar em cima desse projeto. Todos nós acreditávamos em duas coisas basicamente: em uma utopia de um mundo melhor e numa sociedade mais socialista (do ponto de vista da intervenção do Estado), mais comunitária, menos autoritária.

As palavras de Theodoro atestam a presença de uma concepção de história e de trabalho acadêmico enquanto projeto social. Nos termos propostos por Josep Fontana, integrado a essa perspectiva de trabalho intelectual, o pesquisador se liberta da sua condição de especialista para se tornar um participante que faz a crítica do presente e propõe a invenção do futuro ${ }^{80}$.

\footnotetext{
${ }^{78}$ Luis da Câmara Cascudo escreveu sobre o tema em 1941 no livro Fanáticos da Serra João do Vale.

${ }^{79}$ SILVA, J. T. Raízes da Ideologia do Planejamento. Nordeste (1889-1930). São Paulo: Livraria Ciências Humanas, 1978.

${ }^{80}$ FONTANA, J. História: análise do passado e projeto social. Bauru: EDUSC, 2003.
} 
Arrigucci Jr., durante a entrevista concedida, sugeriu que a sua opção por estudar a obra cortazariana fazia parte de um contexto social e político mais amplo, tendo sido uma possibilidade de dialogar diretamente com questões do seu próprio tempo:

Havia começado a estudar a obra de Jorge Luis Borges e pensei em fazer uma tese de doutorado sobre ele. Quando comecei a escrever, o trabalho se chamava Por los senderos del laberinto... Nesse momento eu tinha descoberto o Cortázar e estava metido nessa coisa política, descoberto o universo de contradições da história brasileira, vivendo o clima da Maria Antônia, e o Cortázar começou a me falar mais de perto! Então resolvi me dedicar a uma série de coisas do ponto de vista teórico. A questão da destruição da literatura. Havia um clima sobre a morte do romance, a dissolução da literatura na vida, temas que voltaram com muita intensidade nesses anos 1960 e 1970. Essas teses repetiam muito questões da vanguarda e do surrealismo e voltaram com muita contundência nesses anos. Quando comecei a me enfronhar na obra de Cortázar, descobri que ele representava tudo isso. Percebi que se o Borges era importante, no Cortázar também havia uma dimensão bastante nova e que dizia respeito mais de perto ao horizonte imediato da experiência histórica que eu estava vivendo. Decidi então escrever a tese sobre o Cortázar.

As pesquisas e publicações de Arrigucci Jr. permaneceram dialogando francamente com as experiências vividas em seu contexto histórico imediato, tanto que as análises baseadas nessa convivência política e profissional possibilitaram a elaboração de avaliações e críticas literárias originais. Foi Arrigucci Jr. quem primeiro observou que, em algumas produções literárias elaboradas em contextos políticos de exceção, o realismo muitas vezes era expresso através da alegoria, tendo concluído que essa era uma estratégia muito utilizada por escritores ao longo da década de 1970 tanto no Brasil quanto na Argentina ${ }^{81}$.

Em um ensaio intitulado "O Baile das Trevas e das Águas", publicado originalmente no semanário Opinião, o Prof. Davi Arrigucci examinou o livro Reflexos do Baile publicado por Antônio Callado em 1976. O artigo foi censurado na primeira tentativa de publicação já que resenhava uma obra a respeito do sequestro de um embaixador americano durante um baile de gala em homenagem a rainha da Inglaterra. Para Arrigucci, Reflexos do Baile representa "um mosaico que, a seu modo, é também

\footnotetext{
${ }^{81}$ Walnice Nogueira Galvão comenta essa questão em seu livro Saco de Gatos. Ver: GALVÃO, W. N. Saco de Gatos: ensaios críticos. Op. Cit.. Na obra Achados e Perdidos, Davi Arrigucci aborda a poética da destruição do escritor argentino Júlio Cortazar e examina aspectos importantes das alegorias criadas e desenvolvidas em Histórias de Cronópios e Famas e Jogo de Amarelinha.
} 
um romance histórico e político", tendo utilizado uma "fina alegoria irônica pode ser considerado o mais bem feito dos romances de Callado" ${ }^{\text {" }}$.

O engajamento intelectual traduzia-se na tentativa de compreender as especificidades da formação econômica e social brasileira, da política e da organização do Estado. Muitas vezes, seguindo a trilha de Caio Prado Jr., Florestan Fernandes, Sérgio Buarque de Holanda e Antônio Cândido, lançava-se mão de elementos que pudessem contribuir para uma análise concreta do presente. Como bem definiu Roberto Schwarz, um dos principais símbolos responsáveis por moldar a formação dos intelectuais que viveram a experiência repressiva, foi o fato de compartilharem o ideal e o compromisso em relação à questão pública.

Adorno ressaltou durante a entrevista que quando ingressou no curso de Ciências Sociais em 1971, portanto, já estabelecido na cidade universitária, havia um grande esforço por parte dos professores para superar os entraves impostos pela ditadura. Em suas lembranças, destacou-se a menção feita em relação à manutenção de um compromisso em torno de um "projeto intelectual" que mobilizava docentes e discentes na instituição:

Quando o Florestan Fernandes publicou A Revolução Burguesa no Brasil, escreveu uma dedicatória em que cita as várias pessoas que trabalharam com ele, tais como o Fernando Henrique, o Octávio Ianni, Gabriel Cohn, José de Souza Martins, entre outros, na qual dizia: "Aliaram a aventura do conhecimento a transformação da sociedade". Esse era o nosso mote, conhecer para transformar. A ideia de que o conhecimento lhe permitiria de alguma maneira ter uma condução mais adequada do ponto de vista político e da transformação. Havia muito esta preocupação. Quando entrei aqui havia um projeto intelectual! Hoje, infelizmente, isso mudou muito. Nós sabíamos que precisaríamos compreender bem o capitalismo no Brasil, a revolução burguesa no Brasil, para a gente saber quais eram as etapas seguintes.

As trajetórias acadêmicas evidenciam que o compromisso com a produção acadêmica era mediada por uma causa mais ampla cujo horizonte era o romantismo revolucionário: ou seja, pela presença de princípios revolucionários alimentados por concepções utópicas que projetavam a construção de um mundo melhor e de um país igualitário e livre do autoritarismo. Os docentes relataram muitas vezes que a decisão pela área de humanidades esteve intimamente vinculada a um contexto no qual esses

\footnotetext{
${ }^{82}$ ARRIGUCCI JÚNIOR, D. Achados e Perdidos - ensaios de crítica. São Paulo: Polis, 1979, pp.59-75.
} 
princípios faziam parte do oxigênio mental que alimentava as perspectivas políticas de estudantes secundaristas e universitários.

As memórias docentes trouxeram à tona, a partir dos relatos construídos no tempo presente, explicações que procuram vincular a escolha da carreira acadêmica a uma espécie de "projeto intelectual" embasado em uma perspectiva cultural romântica e revolucionária. A intenção dos docentes através da reelaboração de suas memórias é explicitar o fato de que os motivos ligados à eleição dos cursos pertencentes à Faculdade de Filosofia extrapolavam os limites estritamente profissionais. Na maior parte das entrevistas, o contexto político de exceção e o contato com as contradições e desigualdades sociais aparecem como elementos que motivaram a decisão dos docentes pelos cursos da área de humanas e, ademais, pela carreira intelectual. Para Adorno, a opção pelas humanidades "era uma decisão intelectual e de vida":

Então acho que era diferente porque quando se tomava a decisão de ir para a área de humanas, ela era muitas vezes antiprofissional, já que não havia muitas oportunidades de trabalho. Essa era uma decisão intelectual e de vida. É como se eu quisesse ser um artista. A gente sabia que ia encontrar certos obstáculos na vida, mas acreditava muito naquilo. Então meus estudos são fruto de um ambiente favorável em casa, daquela efervescência política e da vontade de querer conhecer o mundo.

A preferência pelas humanidades, segundo Adorno, beirava a escolha dos artistas pela arte porque havia um sério risco de que a opção por essa área de estudos não resultasse em um trabalho formal e/ou bem remunerado: "Confesso que fiquei meio inclinado para a carreira de direito, mas em 1967 o colégio estava politicamente muito fermentado. A gente ia muito para as passeatas, discutia muito o que estava acontecendo". Adorno ainda acrescentou que "o estímulo para ir para as áreas de ciências sociais era muito grande. Tive professores que tinham estudado História, Ciências Sociais e Letras aqui na USP e eles eram modelos para mim. Aliás, acho que essa era uma questão muito importante, nós tínhamos modelos".

Francisco de Oliveira iniciou suas atividades acadêmicas na Faculdade de Filosofia da Universidade do Recife, atual Universidade Federal de Pernambuco (UFP), onde se formou em Ciências Sociais. Atuou profissionalmente no Banco do Nordeste, tendo mais tarde trabalhado com Celso Furtado na Superintendência de Desenvolvimento do Nordeste (SUDENE). Expulso da mesma pelo golpe de 64, passou 
a trabalhar em São Paulo e, a convite de Octavio Ianni, integrou-se ao grupo de pesquisadores do CEBRAP. Sua atividade como professor universitário teve início na Pontifícia Universidade Católica de São Paulo (PUC-SP) no ano de 1980, quando começou a dar aulas no curso de Pós-Graduação em Economia. Dentre os professores titulares da Universidade de São Paulo que fazem parte da comunidade docente estudada, foi o último que ingressou na carreira mediante convite, que foi realizado no ano de 1988, e sem ter uma tese de doutorado defendida stricto senso. A partir de sua reconhecida produção intelectual obteve o título de "notório saber" em 1992, concedido pela Congregação da FFLCH-USP. Oliveira relembra que o curso de Sociologia era visto com desconfiança pelos amigos. Aqueles que buscavam uma carreira segura preferiam a Faculdade de Direito:

Então sou socialista antes de ser sociólogo! Talvez por essa influência eu tenha confundido Sociologia com Socialismo e, assim, fui fazer Faculdade de Ciências Sociais. Quanto aos meus amigos, a maior parte foi fazer a Faculdade de Direito, considerada uma das três grandes faculdades do Recife, juntamente com a Faculdade de Medicina e a Faculdade de Engenharia. Já a Faculdade de Sociologia era praticamente o patinho feio porque ninguém sabia exatamente para que servia.

Como a Faculdade de Sociologia soava como uma possibilidade mais concreta de lidar com questões próximas às causas socialistas, a preocupação com a empregabilidade acabava ficando em segundo plano. Mas, se a opção pela área de humanas não estava ligada de imediato à questão profissional, era preciso afiançar um emprego formal que garantisse a sobrevivência. $\mathrm{O}$ comentário irônico e bem humorado de Oliveira é expressão fiel do dilema profissional vivido por seus pares naquele contexto:

Sempre tive uma enorme dificuldade para explicar para a minha mãe o que eu fazia... É uma situação engraçada! Como ela era uma mulher muito prática e que tinha que criar dez filhos porque, infelizmente, meu pai faleceu muito cedo, ela me aconselhava: "Meu filho, faça o concurso do Banco do Brasil...". Acho que devia ter seguido o conselho dela. Eu certamente estaria em melhores condições financeiras... Até hoje me divirto muito quando lembro do seu conselho. Mas, afinal, tive sorte de ir parar no Banco do Nordeste porque senão estaria como a imagem do filósofo nas piadas populares: chutando lata vazia no meio da rua. 
Coggiola também falou sobre a sua formação básica na Argentina e a decisão de cursar História. Comentou que a opção pela área de humanas no contexto histórico argentino não foi uma simples escolha entre possibilidades de carreira, mas parte de um projeto coletivo e politicamente explícito:

Fui para a universidade estudar História, curiosamente, por uma opção política. Na escola secundária, no Montserrat, depois de me afastar dos peronistas católicos e dos foquistas, acabei integrando uma organização política chamada Esquerda Nacional, um misto de trotskismo e nacionalismo de esquerda, e lá disseram que precisavam de gente na Faculdade de Filosofia da Universidade Nacional de Córdoba (UNC). Nessa instituição havia cinco cursos: Pedagogia, Letras, Psicologia, Filosofia e História. Chegaram a me perguntar qual curso escolheria e acabei decidindo por História. Ingressei em História em 1970 e então atuei no movimento estudantil dessa faculdade. A universidade estava fervendo, havia assembleias todos os dias, a esquerda mandava, mas, curiosamente, os professores eram extremamente conservadores. Sobretudo tínhamos uma história muito tradicional. Estudávamos história da Grécia, por exemplo, com um livro de 1910. Um absurdo!

É significativo observar como Coggiola explicou o seu ingresso no curso de História como parte de um projeto coletivo, inscrevendo a sua decisão no interior de um ideal político mais amplo. Nesse sentido, a decisão de cursar História é apresentada como parte integrante das necessidades do movimento estudantil e de combate ao autoritarismo. A narrativa encontra-se impregnada de sentido político e, portanto, objetiva, por intermédio da memória, circunscrever o seu autor como sujeito histórico pleno.

Ciente de que "a memória recorta o quer" no tempo presente, Janice Theodoro permitiu a si mesma desenvolver uma reflexão capaz de reavaliar a sua decisão de cursar História. Para a professora, uma análise que leve minimamente em consideração o contexto político é suficiente para se perceber que a opção pela área de humanas não dizia respeito apenas a uma decisão profissional:

Prestei vestibular na USP em História, em Sânscrito e em Ciências Sociais. Entrei nas três. Cursei, de início, História e Ciências Sociais. Mas, na época, Sânscrito era um mecanismo para entrar: se você não entrasse em nada você fazia as optativas em Sânscrito e depois passaria para a História ou Ciências Sociais. Isso foi em 1968. Nessa época fazer Ciências Sociais e História tinha, evidentemente, uma forte conotação política. Pergunto hoje, em que medida, de fato, a minha vocação era aquela, ou se a própria circunstância histórica foi 
que me levou a escolher História e Ciências Sociais. Talvez, hoje, preferisse Sânscrito... Como trabalhava não dava para fazer duas faculdades. Era impossível. Então preferi ficar com a História porque tinha mais empatia com os professores.

\title{
1.4 Memória sobre a repressão.
}

\author{
Tempo negro, temperatura sufocante. $\mathrm{O}$ ar \\ está irrespirável. O país está sendo varrido \\ por fortes ventos. Máxima: $38^{\circ}$, em Brasília: \\ Mínima: $5^{\circ}$ nas Laranjeiras. \\ Jornal do Brasil, 14 de dezembro de 1968.
}

Todas as entrevistas foram realizadas sob o impacto da apresentação do Projeto de Lei 7.376/2010 que propiciou a instalação efetiva da Comissão da Verdade no Brasil em maio de 2012. Com o objetivo de "examinar e esclarecer as graves violações de Direitos Humanos praticados entre 1946 e 1988”, a Comissão da Verdade contribuiu para recolocar na ordem do dia a questão dos assassinatos cometidos por agentes do Estado, das investigações e buscas pelos desaparecidos políticos, do esclarecimento sobre prisões, torturas, espionagem e perseguições contra cidadãos brasileiros durante a ditadura civil-militar.

As entrevistas evidenciaram aspectos cotidianos da repressão empreendida à universidade e a toda sua comunidade, observada desde os primeiros levantamentos feitos pelo Projeto Brasil Nunca Mais no início dos anos 1980. As informações tabuladas e analisadas a partir de 695 processos de réus da ditadura mostraram que $39 \%$ dos atingidos tinha idade igual ou inferior a 25 anos e uma grande parcela possuía escolaridade universitária ${ }^{83}$. Os dados apresentam fortes indícios de que o clima repressivo fazia parte do dia a dia das universidades e atingiram direta ou indiretamente o convívio e a formação acadêmica de uma comunidade que estava sob rígida e permanente vigilância do Estado ditatorial. A condição de funcionários públicos justificava para os agentes responsáveis pela vigilância um controle ainda mais estreito das ações docentes.

A Assessoria Especial de Segurança e Informação (AESI) da USP foi criada oficialmente em maio de 1973 e estava subordinada à Divisão de Segurança e

\footnotetext{
${ }^{83}$ Arquidiocese de São Paulo. Brasil: Nunca Mais. Petrópolis: Vozes, 1985, pp.85-86.
} 
Informação do Ministério da Educação e Cultura (MEC) que, por sua vez, pertencia ao Sistema Nacional de Informações $^{84}$. A sede da AESI na USP estava vinculada diretamente à reitoria e era responsável por investigar supostas atividades desenvolvidas por alunos e professores contra os interesses da ditadura. O principal responsável pela direção da AESI - USP era o Sr. Leovigildo Pereira Ramos, conhecido como "Dr. Leo", que trabalhava em uma sala próxima ao gabinete do reitor.

Entre os docentes entrevistados, Abdala Jr. passou pelo processo de "triagem ideológica" da AESI-USP que, afinal, quase o impediu de ingressar como professor, mesmo depois de ter sido aprovado em concurso público:

Havia duas formas de concurso: o designado de seleção interna, cujo
professor era contratado a título precário - depois virou CLT -, e o
concurso para a carreira de funcionário público. Fiz diretamente um
concurso público para nomeação e passei, mas sabia que ia ter
problemas. Comecei a acompanhar o meu processo de nomeação, ele
saiu de um setor da USP e foi para outro, até que ele chegou às mãos
do reitor rapidamente. O problema é que o reitor não assinava.
Quando procurei investigar o que estava acontecendo, vi que meu
nome estava na chamada "Triagem ideológica da USP", que
funcionava junto ao gabinete do reitor. Fui recebido por Leovigildo
Pereira, uma pessoa que procurava mostrar-se simpática, mas que era
um agente do Serviço Nacional de Informação. Essa informação foi
ele próprio que passou para mim e outros colegas. O Leovigildo dizia
os procedimentos da triagem ideológica não dependiam dele e que ele
era apenas um intermediário. Contou-me ainda que existia a chamada
Comunidade de Informações que recebia dossiês dos vários serviços
secretos e que um coronel que comandava a triagem da USP, não
recomendou a minha nomeação.

Como parte integrante do perfil dos atingidos pela repressão política e militar, a comunidade docente pesquisada relatou as marcas deixadas pela ação dos órgãos de espionagem, informação e ação repressiva direta. As lembranças sobre os momentos vividos na prisão e algumas menções sobre a tortura coabitam com narrativas que

\footnotetext{
${ }^{84}$ Segundo o Prof. Rodrigo Pato Sá Motta, o governo dispunha de agências de informação específicas para vigiar a comunidade universitária, as chamadas Assessorias de Informações e Segurança (ASIs). Segundo Rodrigo Pato Sá Motta, "no âmbito das universidades, as AESI foram criadas a partir de janeiro de 1971, após o Ministério da Educação e Cultura ter aprovado seu Plano Setorial de Informações. Poucos dias após a aprovação do Plano, a DSI do MEC mandou ofício circular às universidades acompanhado da documentação relativa à criação das AESI, em que recomendava a nomeação do chefe responsável em prazo de 10 dias. (...) No caso da Universidade de São Paulo a AESI foi formada apenas em outubro de 1972". Ver: MOTTA, R. P. S. "Os olhos do regime militar brasileiro nos campi. As assessorias de segurança e informações das universidades". Topoi, v. 9, $\mathrm{n}^{\circ}$ 16, jan.-jun. 2008, p.30-67. Ver também: MOTTA, R. P. S.. A modernização autoritário-conservadora nas universidades e a influência da cultura política. In: MOTTA, R.P.S.; REIS, D. A.; RIDENTI, M.. (Org.). A ditadura que mudou o Brasil: 50 anos do golpe de 1964. Op. cit., p. 48-65.
} 
procuram explicar o significado das propostas e projetos de uma geração instruída por compromissos sociais mais amplos. As fagulhas do passado provenientes da memória, como elucidou Walter Benjamin, são responsáveis por trazer ao presente questões que promovem uma história aberta, não linear, que tem por objetivo uma crítica ao historicismo e um acerto de contas com a versão oficial e o apagamento da memória imposto pelos militares. Nesse momento, privilegia-se a entrada dos narradores em cena e o teor de suas lembranças a respeito de experiências vividas sob a ditadura.

"Muitos dos mais brilhantes, inteligentes e vivazes dos nossos colegas morreram precocemente. Trata-se de uma geração que misturou a alegria daqueles anos 1967 e 1968, com o luto que até hoje está sendo feito", comentou Matos. As referências ao período de formação universitária estão marcadas pela presença da dor e do medo. As memórias reelaboradas no presente reivindicam a investigação e apuração dos crimes cometidos pela ditadura civil-militar como única possibilidade de se superar traumas e de curar feridas ainda abertas: "Trata-se de uma ferida que até agora não se cicatrizou. Isso pode ser percebido nos momentos em que se discute a questão da Comissão da Verdade. É como se fosse um luto impossível... Isso vem do trauma mesmo, não é? E chegou o momento de ser elaborado", completou a professora.

Alguns colaboradores foram incentivados a tratar dos momentos nos quais a repressão da polícia-política abateu sobre a USP nos anos 1960 e 1970, influenciados pela discussão em torno da presença da Polícia Militar na cidade universitária em decorrência do assassinato de um estudante de economia durante um assalto em maio de 2011. Ao longo do ano de 2012, algumas operações da polícia militar dentro do campus ocasionaram a revolta de uma parte da comunidade docente e discente e manifestações foram realizadas pedindo a sua saída. Nesse sentido, as questões colocadas pelo presente estimularam certos recortes realizados pelas memórias e a articulação de comparações entre o presente e o passado.

Em sua entrevista, Olgária Matos defendeu a importância de se diferenciar os problemas vividos no contexto democrático contemporâneo das experiências habitadas pela sua geração durante a ditadura militar. Para a professora, ambas as questões precisam ser analisadas especificamente em seu próprio contexto:

Durante a ditadura havia a presença de espiões nas aulas. Via-se estudantes sendo retirados das salas de aula. Era um terror ter que conviver com a polícia lá dentro. Hoje, quando os estudantes falam 
que todo mundo é fascista, que nós professores somos fascistas, que a universidade é fascista e que o reitor é fascista, eles não têm a menor ideia do que é viver no medo. Essa geração não tem ideia do que é viver com medo. A pior coisa que pode existir em uma sociedade é viver sob o domínio do medo. Isso é a ditadura.

As palavras da professora exigem uma avaliação mais balizada por parte daqueles que não experienciaram as situações de medo vividas pela sua geração ao longo da ditadura. As colocações de Matos representam a sua decepção em relação à incapacidade das gerações mais novas compreenderem o significado de viver um cotidiano dominado pelo medo e estudar em meio a uma "vida universitária asfixiada":

Era um período de temor, onde você era vigiado, sequestrado pela polícia política, pela Operação Bandeirantes (OBAN). Havia escuta telefônica. Até muito recentemente eu dizia para pessoas que me ligavam: "Não vamos falar sobre isso por telefone". Havia, além disso, todo um sistema de intimidação que inibia o pensamento. Quando você está sob o domínio do medo, acaba interiorizando o trauma e passando a pensar menor. Você só pensa dentro do que é permitido pensar. A vida universitária fica asfixiada.

As lembranças de Matos procuraram retratar a presença no cotidiano universitário do "domínio do medo" e como a repressão política alcançou a sua própria experiência individual:

Estou citada em três ou quatro processos dos quais eu nem tinha conhecimento. É preciso levar em consideração uma questão muito significativa: o terror não é somente uma prática para aterrorizar quem você quer subordinar, o terror também é a prática de quem está aterrorizado. Como os militares não sabiam de onde vinha o que eles chamavam de terror, todos para eles eram terroristas. No meu processo, por exemplo, é possível encontrar várias fantasias, porque quando faltavam elos nas histórias eles simplesmente inventavam coisas que nunca tinham acontecido. Nesse sentido, existe algo muito importante também que precisa ser entendido: quando uma pessoa que pertencia a alguma organização de esquerda era presa, ela tinha a orientação de seu grupo de dar nomes de pessoas menos engajadas porque, assim, não poderiam informar coisas e isso permitia que os organizados tivessem tempo de mudar de endereço. Essa prática poderia também levar pessoas a serem torturadas sem saber de nada. Mas, enfim, essa era uma ideia da época.

Diante de informações que foram acessadas recentemente graças à abertura de arquivos pertencentes ao exército e à polícia política, inaugurou-se para as vítimas o 
desafio de tentar desvendar como e por que os órgãos repressivos funcionavam e agiam na tentativa de incriminar seus alvos. Outra dimensão dessas lembranças está atrelada à necessidade de compreender como os próprios militantes agiam para defender a si mesmos e seus companheiros. Como ressaltou Matos: "a minha prisão, na verdade, ocorreu por via indireta. Um apartamento de um colega meu, onde funcionava um aparelho, caiu, e lá a polícia encontrou uma carta onde era citado o meu nome”.

A pressão psicológica pela qual passou a comunidade docente contava com o agravante de que seus membros tinham consciência de que, para os aparelhos de inteligência e órgãos repressivos, eles se adequavam enquanto alunos e ou professores universitários a um perfil considerado especialmente perigoso em uma escala na qual "todos eram considerados terroristas".

O conjunto das entrevistas evidenciou a presença de uma forte vigilância no interior da universidade que afetava o dia a dia de alunos e professores. Além disso, muitos docentes narraram experiências diretamente ligadas à prisão, ao encarceramento e à tortura durante os anos de chumbo. Moisés narrou como se deu a sua prisão justamente na principal cena cultural de resistência em São Paulo em um período anterior ao AI-5:

Fui preso aqui no centro de São Paulo na Galeria Metrópole, ao lado da Biblioteca Mario de Andrade. Ali tinha uma livraria que era ao mesmo tempo um local de shows de música popular e reunião de intelectuais e artistas que se chamava Ponto de Encontro. Essa livraria era na verdade um centro de reunião de gente da esquerda e era uma forma de ter um ponto público para se encontrar. O dono dessa livraria era o João Carlos Meirelles que também tinha sido da ação católica e, alguns anos depois, ele foi vereador pela ARENA que apoiava o Golpe. Na condição de vereador e com uma posição de esquerda dentro da ARENA - isso é muito inusitado -, ele foi cassado em 1969. Ele perdeu o mandato e depois foi para o MDB. Houve várias coisas desse tipo entre 1964 e 1969, eram alternativas que parte do movimento de massas organizava para poder fazer política. Porque a política pública estava proibida. Se eu pudesse categorizar isso, diria que foram experiências no sentido de aproveitar espaços culturais, religiosos ou de corporações, ou sindicais para se criar espaços para as pessoas encontrarem e para fazerem política. Era uma alternativa de organização fora dos espaços públicos onde a ação política estava proibida. Isso aconteceu em vários países da América Latina e aconteceu nesse período que vai de 1964 e 1969.

Antes da instauração do AI-5, as vítimas da repressão respondiam a Inquéritos Policiais e Militares (IPMs). O objetivo desses inquéritos era reunir provas para impedir 
as atividades políticas dos seus alvos, mantendo-os sob vigilância constante. Albuquerque, que havia desenvolvido um importante trabalho à frente do Movimento de Educação de Base ligado à Conferência Nacional dos Bispos do Brasil (CNBB), também foi preso para averiguações:

Em razão desse trabalho respondi a dois Inquéritos Policiais Militares (IPM). Os IPMs eram operados diretamente pelo Exército. Havia uma coordenação nacional dos IPMs, um deles focalizado no Plano de Alfabetização Nacional do Ministério da Educação, dirigido pelo Paulo Freire, e outro visava a Comissão Nacional de Cultura Popular, também do ministério da Educação, e na qual eu representava o MEB. O Coronel que dirigia um IPM ganhava diárias e, com isso, tinha um incentivo para esticar o assunto. Uma vez fui chamado lá e o responsável pelo meu IPM - depois descobri que era o então coronel Otávio Medeiros, mais tarde Chefe do SNI e quase candidato a presidente - repetia as mesmas perguntas das quais já sabia as respostas, não importava, eu tinha que repetir tudo de novo. Eu imagino que essa era uma coisa generalizada.

As investigações a que Albuquerque foi submetido em dois IPMs acabaram interferindo diretamente na definição de sua opção por deixar o país em 1965:

Eu ia acabar me envolvendo cada vez mais com política clandestina. Por tudo isso resolvi tentar obter uma bolsa que estava sendo oferecida na área de humanas pelo governo belga em 1965. Era muito raro obter bolsa no exterior na área de humanas. Eu conhecia uma pessoa que já estava lá na Universidade de Louvain, estudando Filosofia e gente que no passado tinha sido da JUC. Então fui selecionado para a bolsa e fui para lá fazer Sociologia com aquela ideia de que a sociologia me daria os instrumentos de fazer a revolução que a gente não tinha conseguido fazer. Eu tinha 24 anos em $1965 . .$. Eu ainda era muito ingênuo em relação a nossa capacidade de ação e de revolução.

Albuquerque também relembrou o período de repressão vivido no retorno ao Brasil quando começou a ministrar aulas no curso de Ciências Sociais da USP. Não foram raros os recortes privilegiados pelas memórias docentes que explicitam situações cotidianas que dão a dimensão de como a universidade era vigiada e de como a ditadura tentava controlar as suas ações educacionais:

No que diz respeito ao ambiente político houve um desafio grande em 1973. O pior ambiente político pelo qual passei foi nessa época e isso era mais comum do que se pensava. Desde 1968 quando houve aquela invasão da cidade Universitária, as coisas pareciam relativamente 
calmas, mas tensas. Quais eram os sinais de tensão? O mimeógrafo. Não existia mimeógrafo. Quando você precisava de algo o professor tinha que ir ao setor da faculdade responsável e requisitar que o documento fosse mimeografado. É uma coisa ridícula, mas eficaz. De um lado, pura bobagem porque os livros estavam ai, todos na biblioteca, só que atrapalhava um pouco.

Albuquerque narrou ainda que as deficiências instrumentais se somavam ao cerceamento político, que tinha o intuito de dificultar a preparação das aulas e o acesso aos textos por parte dos alunos, o que nem sempre surtia efeito:

Uma vez um colega, o Braz Araujo, que era ligado ao Partidão, precisava copiar uma série de textos clássicos do Marx e do Engels para um curso que ele ministrava. No caso ele não usaria o mimeógrafo, mas umas máquinas impressoras de chapa que copiavam com melhor qualidade, o Multilith. Só foi obter autorização quase no fim do semestre. Qualquer outro que não fosse o Braz, já teria desistido, mas ele não. Eu mesmo só fui conseguir dispor de uma máquina de xerox vinte anos mais tarde, nos anos 1990, com o dinheiro da Fundação Ford. Essas coisas não tinham a ver apenas com política, só que se somavam às restrições políticas.

Como já foi dito, as várias reportagens publicadas durante a aprovação e abertura dos trabalhos da Comissão da Verdade em 2012, reacenderam e estimularam as memórias dos colaboradores. Diante da publicação de uma reportagem que tratava da morte de Luis Eduardo Merlino nas vésperas da entrevista, Theodoro relembrou a sua própria prisão em meio a lembranças de amigos que também estiveram presos e morreram no mesmo contexto:

Fui presa em 1971. Lembro-me que fui presa quando o Lamarca morreu. Fiquei presa mais ou menos seis meses. Primeiro passei pela Operação Bandeirantes (OBAN). Da OBAN fui para o DOPS Departamento de Ordem Política e Social e, desse departamento, fui levada para o presídio Tiradentes. Foi um período extremamente difícil. Eu estava lendo um jornal agora e me lembrava do Luis Eduardo Merlino ${ }^{85}$ que tinha sido colega de turma e foi morto na

85 Segundo informações pontuadas por Janice Theodoro da Silva: Luiz Eduardo Merlino (Santos, SP, 1948-1971) participou, ainda secundarista, do Centro Popular de Cultura (CPC) da União Nacional dos Estudantes (UNE). Mudou-se para São Paulo e, em 1966, fez parte da primeira equipe de jornalistas do recém fundado Jornal da Tarde (1966), do grupo $O$ Estado de S. Paulo. Nesse jornal escreveu algumas reportagens como a que denunciava as atividades do "mau patrão" Abdala, da Fábrica de Cimento Perus/SP (Jornal da Tarde de 24 de abril de 1967). Trabalhar também como jornalista na Folha da Tarde (1968) e depois no Jornal do Bairro(1969-1970). Participou da equipe do jornal alternativo Amanhã. Estudante de História da Universidade de São Paulo (USP), cobriu, em outubro de 1968, o $30^{\circ}$ Congresso da UNE, em Ibiúna (SP), para a Folha da Tarde. Como jornalista, foi um dos 
prisão. Lembrei-me de outros companheiros daquela época que também foram mortos. Foi um período muito difícil, trágico, doído. E a vida dentro dos partidos políticos também era difícil. A condição humana em situações limite apresenta com mais força suas ambiguidades.

Nenhum dos entrevistados torturados pelos órgãos de repressão falou sobre as circunstâncias ou consequências físicas e psicológicas. Citações à tortura foram realizadas muito pontualmente. Provavelmente, a resistência em tratar do tema também está ligada à ênfase dada pelos colaboradores à carreira intelectual. Além disso, o silêncio em relação à tortura circunscreve a questão a uma esfera de importância particular e reservada, portanto, à intimidade. No entanto, a sua citação não pode ser considerada mero acaso, os narradores que expressam esse trauma esperam que a simples menção ao fato traga à tona a dimensão de denúncia que ela deve acarretar em si mesma no contexto de democracia política.

Zilda Iokoi relatou objetivamente que tendo desenvolvido intensa atividade militante no movimento estudantil pelo PCB foi perseguida, presa e torturada:

Acho que o tema da intolerância me acompanhou desde cedo porque como eu tive sequelas de poliomielite e, em decorrência disso, deficiência física, a discriminação, os preconceitos e a intolerância contra os deficientes me acompanharam desde cedo. Depois também sofri problemas com a intolerância política porque, vinculada à esquerda, membro do Partido Comunista Brasileiro e depois do Partido Comunista Brasileiro Revolucionário, sofri os impactos da ditadura: fui presa e torturada.

Abdala Jr. também narrou os momentos de terror vividos nos anos da ditadura:

Quando houve o AI-5 a coisa complicou. Em 1969, eu fui preso pelo exército e fiquei sob prisão por um ano e cinco meses. Passei

poucos presentes que escaparam da prisão. Nessa época, já havia ingressado no Partido Operário Comunista (POC). Foi preso na casa de sua mãe, em Santos, no dia 15 de julho de 1971. Tinha, na época, 23 anos e havia acabado de retornar de uma viagem à França, feita para estreitar contatos com a IV Internacional. Levado para o DOI-CODI de São Paulo, na Rua Tutóia, foi, conforme o livro Direito à Memória e à Verdade, editado pela Comissão Especial de Mortos e Desaparecidos do Ministério da Justiça, "torturado por cerca de 24 horas ininterruptas e abandonado numa solitária, à chamada 'celaforte', ou 'x-zero"” (Brasília, 2007, pp. 169-170). Faleceu segundo laudo necroscópio de anemia aguda traumática por ruptura da artéria ilíaca direita. O laudo foi assinado por Isaac Abranovich e Abeylard de Queiroz Orsini indicado como razão do ferimento, um atropelamento. Pelo testemunho de diversos presos que estiveram com ele sabe-se que morreu em razão das torturas que sofreu. A imprensa foi proibida de noticiar a morte embora um anúncio fúnebre tenha sido publicado no jornal $O$ Estado de São Paulo convidando para uma missa de $30^{\circ}$. dia, que foi celebrada na catedral da Sé. 
inicialmente pelo Forte Itaipu e, depois, pela Operação Bandeirantes (OBAN), que não tinha sequer existência legal no próprio sistema ditatorial. Sob tortura, foram os próprios agentes da repressão que disseram isso para mim, chegando mesmo a enfatizar que nada daquilo existia, que eu próprio não existia... Entendi o procedimento como mais uma ameaça, para além da tortura. Depois da Operação Bandeirantes passei para o Departamento de Ordem Política e Social (DOPS), onde houve a formulação do processo e, daí, fui ter ao Presídio Tiradentes, onde fiquei preso a maior parte do tempo. Fui posteriormente condenado e, curiosamente, quando a pena de um ano de prisão foi decretada, eu já tinha não só cumprido a mesma como tinha ficado mais tempo. Assim mesmo meu advogado recorreu e fui absolvido. Não conseguiram provar nada contra mim. Os motivos para a prisão eram na verdade laterais. Não chegaram a conhecer os meus engajamentos mais fortes. Percebi, na prisão, com base em outras prisões, que eles me mantiveram preso como uma forma de pressão sobre possíveis lideranças... E eu tinha certa posição de liderança e uma presença já de longo prazo nas fichas dos órgãos de repressão...

Depois dos períodos mais difíceis atravessados nos porões da OBAN e, já no presídio Tiradentes, Abdala recebeu o auxílio de amigos e a solidariedade de professores, ambos indispensáveis, para que continuasse os estudos na pós-graduação e a carreira universitária.

Coggiola também relembrou episódios de perseguição e prisões no contexto da ditadura argentina, evidenciando com cautela a situação de tortura:

Entre 1969 e 1975 fui preso uma dúzia de vezes devido às minhas atividades políticas, tanto por governos militares (até 1973), quanto sob o governo peronista (1973-1976). Cheguei a ficar dois meses na prisão, não vou entrar em detalhes, fui várias vezes "coagido fisicamente", para usar um eufemismo próprio da época. Quando veio o golpe de 24 de março de 1976, vivia de um lado a condição de "proletarizado" e, de outro, era estudante universitário de Economia e de História. Fui expulso da Universidade de Córdoba em uma lista que tinha 23 alunos expulsos. Dessa lista, 18 estão mortos. Foram assassinados praticamente de imediato. Eu me mudei para Buenos Aires e fiquei clandestino por um ano e, depois, fui para França. Não tinha concluído nenhum dos dois cursos, economia ou história. Cheguei à França em 1977 e me inscrevi em uma universidade. Não tomei o estatuto de refugiado político para conservar meu passaporte argentino. Uma maluquice da época... O que me obrigava a trabalhar feito um louco... Eu vinha de uma repressão bem forte no meu país, meu irmão havia sido sequestrado pelos "grupos de tarefas das Forças Armadas", permaneceu "desaparecido" durante um tempo, o interrogavam sobre meu paradeiro, que ele não conhecia, mas salvou a vida. 
Dentre os muitos episódios de violência cometidos pelas forças de repressão da ditadura no campus e presentes na memória coletiva de alunos e professores, Arrugucci Júnior mencionou um extremamente significativo, vivido durante uma invasão policial que visava prender alunos dentro da cidade universitária:

Em 1973 saiu meu livro, em 1974, A valise e A prosa do Observatório: uma época de grande efervescência política e cultural. Foram anos muito intensos, de grande agitação e duros também. A repressão veio num crescendo. O começo da década de 1970 foi terrível, o governo Médici foi horrendo. Depois do episódio da Maria Antônia o pessoal caiu em cima da universidade. Eu me lembro de que nós fomos detidos no campus numa noite. Estávamos saindo, mas a polícia tinha fechado o campus da USP e prendeu todo mundo. Nós fomos parar no Bloco B, lá ficaram detidos Bento Prado, Sérgio Buarque de Holanda e Boris Schnaiderman, que estava sem seus documentos; precisei ligar para a casa dele. Nós ficamos preocupadíssimos por que o Boris era uma pessoa muito valente, um homem notável e muito firme nas suas posições e convicções. Ele já tinha expulsado de sua sala de aula policiais quando entraram sem mais essa nem aquela para prender um de seus alunos de russo. Ele tinha lutado na Segunda Grande Guerra, fora pracinha, e botou com valentia a polícia pra fora! Não deixou que entrassem na sala e criou um auê! Nessa noite também estava lá a Lygia Fagundes Telles que tinha ido dar uma conferência. Estávamos todos detidos no Bloco B da cidade universitária. Um absurdo completo.

Ao abordar a universidade e as experiências vividas na ditadura militar, as memórias individuais tatearam um cenário bastante traumático. A questão do desaparecimento, das perseguições e do "sentimento de impotência diante da truculência da repressão" marcou profundamente a memória coletiva da comunidade docente. Nas palavras de Arrigucci Júnior:

Continuei dando aulas na Faculdade, que teve de se transferir para a Cidade Universitária. Os tempos eram sinistros: muitos foram perseguidos, foram desaparecendo colegas, outros saíram, havia muito desânimo e grande sentimento de impotência diante da truculência da repressão que pesou de forma brutal sobre a vida universitária brasileira. A duras penas, naquele momento pouco propício, comecei a me dedicar à carreira de professor de Teoria Literária e Literatura Comparada juntamente com o Roberto Schwarz que logo depois, em 1969, teve também de deixar o país, a que só retornaria em 1979. Ele saiu pelo Uruguai e ficou 9 anos na França. Com Antonio Candido, permanecemos eu e a Walnice, mas logo foram entrando novos como a Teresa Pires Vara e o João Alexandre Barbosa, um pouco mais tarde, a Lucilla Bernardet. 
Nas lembranças de Leyla Perrone, sobressaíram também os sentimentos de impotência, insegurança e medo que procuram reconstituir um cotidiano marcado pela repressão:

No fim dos anos 60, além de muito cansada por estar dando aulas em três lugares diferentes, o clima político aqui estava uma coisa medonha. $\mathrm{Na}$ universidade a gente não podia falar. A professora Lucrécia Ferrara, com quem criei o curso de Teoria Literária na PUC, de quem era não só colega, mas muito amiga, foi detida em 1969 para "dar informações" na Operação Bandeirantes. Lembro-me que fui a casa dela lá em Perdizes; como estávamos montando o curso, nós conversávamos bastante. Quando estava chegando próximo à rua da casa dela vi um movimento meio estranho e o marido dela que estava na janela. Quando ele me viu chegando de carro, deu um sinal para eu ir embora... Conto isso para você sentir qual era o clima na época... Eu me lembro que, rapidamente, voltei para casa. Depois fui me informar com outras pessoas sobre o que tinha acontecido. Soube que ela teve tanta presença de espírito que, quando os policiais chegaram, ela chutou a agenda para debaixo da mesa. Isso para ninguém querer pegar todos os amigos dela. Então quando vi o que tinha acontecido com o meu irmão e o que estava acontecendo com a Lucrécia e com outros colegas, como o Prof. Boris Schnaiderman... Hoje ele está com mais de noventa anos. O Boris era professor de literatura russa e, além disso, o filho dele tinha ido fazer treinamento de guerrilha em Cuba. O Boris ficou sendo suspeitíssimo embora não tivesse nada a ver com guerrilha. Ele foi levado mais de uma vez para prestar depoimento e sua biblioteca foi vasculhada.

A sensação de que a polícia estava investigando e prendendo pessoas próximas e ligadas à universidade transformava o cotidiano e inibia ações que pudessem ser consideradas suspeitas, criando-se um círculo vicioso que reproduzia o medo e a insegurança:

E a gente ia acompanhando tudo que ia acontecendo... Então nesta tarde em que voltei da casa da Lucrécia e fiquei sabendo, através de amigos, que ela estava presa e sendo interrogada, fui para a área de serviço de meu apartamento e fiz uma fogueira dentro de uma bacia, com um monte de publicações de esquerda que eu tinha aqui em casa. Jornais e documentos da época foram queimados. Fiz essa fogueira porque pensei: meu irmão é mais que suspeito, é réu foragido, pegaram a Lucrecia, então alguma hora será a minha vez. De repente eles virão saber o que eu faço da vida... E se encontrarem essa papelada toda aqui? Então queimei tudo. Uma pena! Pois havia coisas que eram valiosas para guardar... 
Nas lembranças de Leopoldo e Silva ficaram as marcas dos momentos difíceis atravessados pelo movimento estudantil durante os anos de militância e, dentre elas, a necessidade de encerrar oficialmente as atividades do Centro Acadêmico de Filosofia e ocultar informações para proteger os seus membros:

Durante a ditadura quando era aluno da Maria Antônia, fui graças a certas circunstâncias, por três vezes, membro da diretoria do Centro Acadêmico de Filosofia. Isso aconteceu em alguns momentos porque somente eu era o menos comprometido politicamente, do ponto de vista de um engajamento mais externo. Aconteceu que algumas pessoas tinham que se ausentar definitivamente ou temporariamente, principalmente aquelas mais entrosadas em relação a aspectos mais amplos e, portanto, houve momentos em que o Centro Acadêmico era reduzido a mim. Depois, por precaução, tivemos que dar fim oficial a essa entidade. Destruímos documentos e essa coisa toda porque não havia mais condição de mantê-lo. Mesmo aqui no campus, um lugar longe e ermo, a presença da polícia era muito ostensiva. Tivemos então que dar fim a isso.

Para além do cotidiano dominado pela repressão de Estado e de grupos de direita, houve docentes que chamaram a atenção para a prática de uma postura autoritária promovida pelas esquerdas e da atuação no cotidiano universitário daquilo que chamaram "patrulhamento ideológico". A disposição de alguns docentes em apresentar memórias dissonantes, evidencia a presença de disputas que procuram apontar peculiaridades e contradições, iluminando novas abordagens. Essas memórias ofereceram novas possibilidades para se interrogar a comunidade inscrevendo a negociação entre as memórias pessoais no seio da memória coletiva.

Janice Theodoro narrou vários episódios referentes ao período em que esteve na prisão destacando a presença de um "patrulhamento ideológico" de esquerda que não poupava questões referentes à organização do cotidiano prisional:

$\mathrm{Eu}$, por exemplo, tinha muito medo de barata. E lá na cela do presídio Tiradentes havia aquelas paredes emboloradas... Sabe quando a parede estufa? E fica toda preta de musgo? E você não consegue ver o que tem dentro? Tive então a seguinte ideia... Para melhorar essa situação a melhor coisa que tinha era cal! Venho do interior, então sabia como se cuidava dessas coisas... Então pedi cal para o meu pai. Meu pai me mandou cal! "Prá que você quer cal?", perguntava ele. É para pintar aquele lugar, dar uma limpeza naquele negócio todo, não é? Pintar toda a parede! Eu e umas colegas minhas começamos a pintar a parede e... nova reunião! Diziam: "A Janice está pintando o aparelho repressor!" Eu disse: "Não! Só quero matar as baratas!". Então 
existiram vários momentos difíceis nesse cotidiano... Cheguei a pedir para minha mãe uma privada porque você tinha que fazer as necessidades em um buraco. Quer dizer, eu não estava defendendo o aparelho repressor... Estava defendendo um banheiro! Uma pintura! Comecei a entender finalmente que o dilema estava na formação das pessoas e não, apenas, na definição política. Talvez seja isto. Existe uma natureza humana que precede e se soma, posteriormente, à questão política. Não há política sem moral.

Em outras passagens da entrevista Janice descreveu o seu desconforto em relação à vigilância realizada por alguns prisioneiros sobre ações cotidianas realizadas na prisão, o que contribuiria para o seu afastamento em relação a algumas organizações de esquerda.

Durham também relatou a dificuldade de trabalhar em sala de aula com a problematização de temas e pesquisas no campo da antropologia cujos pressupostos teóricos não fossem marxistas. Comentou, ainda, que para trabalhar com questões de cunho familiar, a resistência de alguns alunos era muito grande:

Era muito difícil lidar com um marxismo absolutamente galopante! Se, de um lado, tinha a censura de governo, havia também de outro um patrulhamento ideológico marxista dentro da Faculdade de Filosofia. Então eu estava entre a cruz e a caldeirinha, não é? Ou você era marxista ou ninguém lhe dava atenção. Agora, se você fosse marxista mesmo, poderia ser presa pelo outro lado... O problema é que o marxismo não se enquadrava muito bem nos problemas enfrentados pela antropologia. Para começar, naquele tempo, a antropologia estudada estava concentrada nos povos "primitivos" e coisas parecidas com os migrantes rurais, etc. Portanto, não dá para pensar essas coisas em termos de luta de classes.

Durham ressaltou diversas vezes a dificuldade em lidar com a presença de certas concepções marxistas ortodoxas e vulgares em sala de aula:

Fazíamos estudos de comunidades e elas não tinham nada a ver com luta de classes. Trabalhei com os migrantes rurais e eles não estavam a fim de fazer nenhuma revolução, muito pelo contrário. Eles queriam arrumar um emprego na indústria em São Paulo. Não havia uma mentalidade revolucionária. Eu não podia sequer falar de classe operária porque os meus migrantes vinham para a cidade e, geralmente, conseguiam seu primeiro emprego na construção civil. Ora, construção civil não é exatamente operariado. 
Perrone-Moisés nunca foi declaradamente uma militante de esquerda, mas fez questão de expressar o seu posicionamento político e a sua solidariedade aos movimentos de resistência à ditadura desde os primeiros momentos da entrevista. Sem que a primeira pergunta fosse feita, a professora iniciou sua fala resenhando o livro $K$. de Bernardo Kucinski ${ }^{86}$, demonstrando a sua emoção e indignação em relação ao caso da Prof. a Ana-Rosa Kucinski Silva, do Instituto de Química da USP. Segundo PerroneMoisés, Bernardo, seu irmão, narrou neste livro como Ana foi punida com a perda do cargo de professora por ter se ausentado da universidade. Todos sabiam que ela havia sido sequestrada e assassinada juntamente com o seu marido por órgãos de repressão da ditadura ${ }^{87}$. E posicionou-se categoricamente, "isso jamais teria acontecido na Faculdade de Filosofia":

Uma coisa que é preciso dizer dessa época toda da ditadura, é que enquanto ela se instalava e se endurecia cada vez mais, a "cultura" da Faculdade de Filosofia, se a gente pode dizer assim, era de esquerda. A grande maioria dos professores se opunha a ditadura, declaradamente ou não.

Tributária e colaboradora da cultura de esquerda na Faculdade de Filosofia, Perrone narrou o seu incômodo em relação ao "patrulhamento ideológico" exercido por alguns militantes vinculados a concepções ortodoxas:

Então, dentro da Faculdade era mais bem visto ser de esquerda do que ser apoiador da ditadura. Existia até mesmo um patrulhamento ideológico de esquerda na Faculdade de Filosofia. Tanto é que na congregação os professores se sentavam bem separados, de um lado os que eram "de direita" e, do outro, aqueles que eram "de esquerda".

O patrulhamento de certos setores da esquerda, segundo Perrone, atingia o cotidiano e pretendia impor normas de comportamento e padrões de relacionamento social:

\footnotetext{
${ }^{86}$ KUCINSKI, B. K.. São Paulo: Expressão Popular, 2013.

${ }^{87}$ O livro de Bernardo Kucinski tem um significado especial para Leyla Perrone-Moisés porque seu próprio irmão desempenhou uma intensa atividade política nos anos de chumbo, descrita na entrevista concedida. Fernando Perrone (1935-2007), formou-se em Química na USP e em 1966 elegeu-se deputado estadual pelo MDB por São Paulo. Depois do AI-5 esteve exilado no Chile e na França. De volta ao Brasil, ingressou como professor na área de Sociologia da Comunicação na Escola de Comunicação e Artes da USP (ECA-USP), onde trabalhou entre 1982 e 1997, quando se aposentou como livre-docente.
} 
Eu tenho uma amiga de muitos anos que era professora do Departamento de História e era considerada "de direita". Ela era minha amiga por outras razões, nós nunca falamos de política. E na congregação, como às vezes as reuniões duravam sete horas - eram muito longas e muito cansativas -, eu me sentava perto dela. Alguns colegas chegaram a chamar a minha atenção e questionavam: "Como você pode se sentar ao lado daquela reacionária?" Isso era um tipo de coisa que eu não podia aceitar. O que era aquilo? Não poder sentar ao lado de uma pessoa que não pensa como a gente? E que era minha amiga por outras razões?

Em um contexto marcado pela bipolaridade direita e esquerda, qualquer posição tomada de maneira autônoma ou independente dos parâmetros pré-concebidos, poderia ser considerada dúbia e, assim, ser imediatamente questionada. Para Perrone, a posição ortodoxa de certos membros da esquerda prejudicava a avaliação de situações que passavam a ser encaradas de maneira maniqueísta. Dessa forma, muitas vezes, aqueles que não se enquadravam perfeitamente nos estereótipos convencionais, acabavam sendo "patrulhados" e coibidos para se comportar segundo os padrões esperados:

Ao mesmo tempo, quem era militante de um partido de esquerda, tinha uma certa blindagem, não é? Qualquer coisa que ocorresse, fechava-se o cerco. Aconteceu no nosso Departamento de uma professora ter sido perseguida pelos tais catedráticos de direita e aí a Faculdade de Filosofia inteira veio em cima do caso para blindar essa professora. O Italo Caroni e eu, que havíamos apoiado os alunos sem saber que eles tinham sido cooptados pelos catedráticos de direita, fomos submetidos a um verdadeiro "processo de Moscou" numa reunião plenária. Foi muito humilhante. $\mathrm{E}$ os catedráticos de direita não foram incomodados, porque tinham poder na instituição. Portanto, nunca achei tanta vantagem moral, digamos, em ser de esquerda na época da redemocratização.

Diante da repressão promovida pela ditadura civil-militar contra a Faculdade de Filosofia, mecanismos internos de defesa foram criados por parte das esquerdas no sentido de proteger aqueles que podiam ser vítima de perseguições externas e internas. As negociações travadas entre as memórias individuais e a memória coletiva, demonstram que a repressão sobre a comunidade docente deixou marcas profundas em sua formação intelectual e política. 


\subsection{A Faculdade de Filosofia em trânsito.}

... uma geração espremida entre dois cenários opostos: a herança do passado autoritário, das feridas deixadas pelas lutas contra o regime militar - entre as quais, as torturas, a clandestinidade, a suspeita de delação, o medo, a insegurança, a incerteza, o exílio, as mortes; e as expectativas de um futuro cujo horizonte de abertura política pareciam estreitos, sobretudo, porque apelavam para a velha fórmula da conciliação ${ }^{88}$.

Depois da "Batalha da Maria Antônia", alunos e professores da Faculdade de Filosofia foram obrigados a transitar da região central da cidade de São Paulo para o campus localizado no bairro do Butantã. Nas memórias daqueles que experienciaram a mudança, o resultado do ponto de vista infraestrutural foi devastador. A FFLCH-USP iniciou os anos 1970 enfrentando sérios problemas para que os professores pudessem ministrar os cursos regulares - já que muitos departamentos foram instalados em barracões de zinco improvisados. A falta de locais adequados de trabalho para os professores e de salas de aula para os alunos, somavam-se às mudanças que começavam a atingir as carreiras docentes e a pós-graduação, novas regras de ingresso na graduação através do vestibular e aos novos currículos construídos a partir de créditos e a necessidades de todas as esferas, inclusive a catalogação dos livros e a sua organização em uma biblioteca.

González dedicou algumas passagens da entrevista à reconstituição do cenário universitário improvisado em que se desenrolavam as atividades cotidianas da maior parte da Faculdade de Filosofia na cidade universitária, com exceção dos cursos de História e Geografia que já tinham prédio próprio:

O catedrático decidiu que como eu tinha feito o doutorado seria o coordenador da área. Não existia isso, mas ele me disse para reunir os professores e discutir o trabalho que deveria ser feito. Ele então olhava de longe. Nessa época, estávamos em 1973, tínhamos deixado os barracões e ido para o Conjunto Residencial da USP (CRUSP). Minha sala era um apartamento de estudantes. Estávamos no terceiro andar do Bloco $\mathrm{C}$, metade do andar era nosso e a outra era de outra área didática. Passei dez anos no apartamento 307 e ao meu lado tinha um chuveiro. Hoje dou risada da situação. Mas na época éramos uma espécie de força de ocupação no CRUSP. Claro que os militares não

\footnotetext{
${ }^{88}$ ADORNO, Sérgio. Memorial de Titulatura. São Paulo: FFLCH-USP, 2004.
} 
sabiam o que fazer com aquilo. Então eles construíram as Colmeias, que funcionavam como salas de aula. O complexo das Colmeias, na verdade, era um projeto que originalmente serviria como espaço para congressos e convenções. Isso que a USP está querendo construir agora, na época da ditadura já estava planejado. O CRUSP estaria integrado a esse projeto e funcionaria como hotel, enquanto as salas pequenas das Colmeias seriam para reuniões fragmentárias dos eventos, sessões de comunicações, por exemplo. E chegaram a construir um anfiteatro de convenções que depois passou a se chamar Anfiteatro Camargo Guarnieri. Eu vi ele ser construído, chamava-se Anfiteatro de Congressos. O que seria o espaço de vivência nos dias atuais seria um setor auxiliar, com farmácia, bancos, agências de viagens, tudo era para ficar lá. Ou seja, o CRUSP seria um grande centro de convenções.

A situação em que se encontravam os livros dispostos sem organização e sem os cuidados mínimos dão uma ideia da situação precária em que estava a Faculdade de Filosofia nos anos 1970. Ainda nas palavras de González:

Quais foram os principais desafios enfrentados na Faculdade? Quando cheguei aqui na USP havia carências por todos os lados. Éramos muito poucos professores e o trabalho era muito. Não havia biblioteca, cada cadeira tinha a sua biblioteca. Quando queimaram a Maria Antônia, eu trouxe os livros para o Instituto de Cultura Hispânica. Como o prédio não podia ser mais utilizado eu tinha que guardá-los em algum lugar, esses livros foram depois transferidos para os barracões da cidade universitária na Veterinária. Lá não havia catalogação, nem organização de nada. Aquilo era um depósito de livros e ninguém encontrava nada. Então, aproximadamente no ano de 1970, na primeira semana de aula em agosto, interrompemos as aulas e ensinamos os alunos a fazerem uma ficha catalográfica dos autores, para os livros e fomos lá para a biblioteca. Os professores ficaram de um lado baixando os livros e os alunos fichando os livros, à mão, do outro. Utilizamos cartolina para ficharmos os livros e organizamos um fichário. Isso foi essencial para usarmos os poucos livros que tínhamos. Os alunos tiveram que fazer isso porque devia haver apenas duas bibliotecárias. Aquilo era um depósito de livros! As carências eram de todo tipo: de pessoal e de infraestrutura. Os prédios eram os barracos da Veterinária, a grande mudança que houve em um determinado momento foi que fecharam as paredes até o teto. Era impressionante, quando chovia era preciso parar a aula! Aquele teto era de um material que não isolava nada, no calor ou no frio era terrível. Chovia, acaba a aula! Isso quando não faltava luz, eu cheguei a dar aula na escuridão. Quando acabou a luz, eu pedi para os alunos ficarem e não parei com a aula. Continuei com a aula sem luz. Aquilo era terrível! O gabinete dos professores eram duas salinhas que não davam para nada. Depois nos trouxeram para o CRUSP. Lá no CRUSP ao menos havia esse depósito de livros, lá nos barracões havia apenas um germe de biblioteca que não resolvia nada. Não havia recursos de qualquer espécie, havia um mimeógrafo para tudo. E o mimeógrafo era um perigo porque reproduzia textos e por isso os 
militares controlavam os mimeógrafos. Havia então um funcionário que lidava com o mimeógrafo que, suponho, sabia, evidentemente, muito bem o que estava fazendo. As carências foram muito grandes nessa época.

Essa situação precária prolongou-se por muitos anos, como atesta a reportagem da Folha de São Paulo "A Filosofia continua funcionando precariamente”, publicada em dezembro de 1983, às vésperas da instituição completar 50 anos:

Cinquenta anos após a sua fundação, A Faculdade de Filosofia, Letras e Ciências Humanas da USP enfrenta grandes problemas com professores espalhados pelos mais diferentes locais, incluindo os jardins, falta de condições para trabalhar, banheiros sujos, ratos e outros animais que encontram pelas improvisadas classes. Em condições das mais precárias estão vivendo 210 docentes entre efetivos, estáveis e contratados e cerca de 3 mil alunos espalhados pelo campus. O maior acervo de livros do país na área de Letras, perto de 200 mil volumes ainda não totalmente catalogados, é muito procurado pelos alunos, mas não está protegida por qualquer esquema de segurança. Exemplares raríssimos que datam dos séculos XVI e XVII estão ao alcance de ratos ou de qualquer pessoa que perambule pelo campus $^{89}$.

Para Leopoldo e Silva, as péssimas condições infraestruturais em que funcionava a maioria dos cursos da Faculdade de Filosofia, faziam parte de um projeto orquestrado pelos militares e que tinha o propósito de isolar as suas atividades do restante da universidade:

Isso tudo para você ter uma ideia das condições precárias e também de certa marginalização da Faculdade. Uma marginalização aberta e do ponto de vista físico. Costumo dizer que a Faculdade de Filosofia sempre foi marginal. Apesar de ela ser o centro da universidade e ter sido fundada com essa função, ela sempre foi colocada de lado em termos de estrutura de poder. Nunca teve uma influência muito grande, a não ser do ponto de vista intelectual. No que diz respeito à organização da universidade, o domínio sempre partiu das grandes escolas profissionais. Essa marginalização, portanto, sempre existiu. Mas com os barracões a gente teve a experiência de uma marginalização completa. A situação de não ter onde ficar, onde comer, não ter lugar para ter uma aula decente, para o professor trabalhar. Enfim, eram barracões muito precários... Chuva, lixo, ratos, enfim, tudo havia lá. E não havia nenhuma intenção de resolver o problema. Qualquer pedido mais incisivo era posto na conta da subversão, da politização, não era levado em conta.

\footnotetext{
${ }^{89}$ Folha de S. Paulo, 18.12.1983. Apud: WITTER, J. S. USP/50 Anos: registros de um debate. São Paulo: Edusp, 2006.
} 
As narrativas que tratam do fechamento da Maria Antônia e da vinda para os barracões da cidade universitária reportam uma sensação coletiva de exílio. A marginalização infraestrutural é lembrada pelos docentes como parte de um processo de sucateamento pedagógico com intuitos políticos. A retirada da Faculdade de Filosofia da sua casa na Maria Antônia, a cassação de professores, a destruição dos vínculos existentes entre os cursos e as disciplinas foram questionados enquanto um conjunto estratégico de medidas, cuja finalidade era limitar as atividades acadêmicas que podiam fomentar críticas ao regime.

Na concepção de Olgária Matos, a ida para a cidade universitária teve o propósito de dispersar as áreas de conhecimento que conviviam proximamente e, além disso, de afastar a Faculdade de Filosofia da região central da cidade:

A vinda para a cidade universitária teve mesmo essa proposta de dispersar as várias áreas e deixar longe do centro da cidade. Então cada curso foi para um canto, nós antes tínhamos aulas em uns quatro lugares diferentes. No começo havia uma parte em Pinheiros e outras onde havia lugar na cidade universitária. No início, fomos até para os barracões da Psicologia. Os psicólogos mesmo já estavam lá improvisados e nos emprestaram algumas salas. Fomos até para a Veterinária. Como muitos professores foram caçados e outros tiveram que fugir, muitos dos meus colegas foram contratados muito cedo para dar aulas. Nessa época o Governo francês oferecia três bolsas anuais para os estudantes formados na graduação e fui com uma bolsa para o exterior. Como não havia ninguém para dar aulas, os melhores alunos eram contratados. Havia também professores que davam aulas em disciplinas que não eram de sua especialidade. Isso era importante para manter o curso em funcionamento e para não haver algum interventor indicado pela ditadura militar.

Para Leopoldo e Silva, a iniciativa de trazer a Faculdade de Filosofia para o campus do Butantã objetivou afastá-la da região central com o intuito de impedir que os cursos de extensão, eventos e debates promovidos pela instituição, pudessem influenciar um público mais amplo:

É engraçado isso, nós estamos há tanto tempo na cidade universitária que esquecemos a importância da localização urbana da instituição... Realmente não foi por acaso que aconteceu tudo aquilo em 1969. Era preciso excluir todo aquele potencial político da Faculdade do ponto de vista geográfico. Anular o lugar de convergência, de reunião e de circulação de ideias. Isso era importante e se mostrou decisivo. Estar no meio da cidade e organizar em pouco tempo, uma ou duas horas, 
uma passeata, uma manifestação, agregando pessoas que estavam por ali e estavam acostumadas a ver aquilo e entrar na Faculdade para acompanhar as discussões.

Não apenas para Leopoldo e Silva, mas para muitos docentes, a transferência da Faculdade de Filosofia para a cidade universitária teria contribuído para o enfraquecimento da presença da instituição - de seus alunos e professores - no espaço público e nas discussões sobre a cidade:

\begin{abstract}
A saída da Faculdade do centro foi um episódio político que depois se desdobrou em outras consequências. Talvez não seja exagero dizer que certo enfraquecimento, desorganização e outras opções que apareceram para o movimento estudantil, tiveram raízes nessa impossibilidade da presença urbana direta que mobilizava muito as pessoas e as ideias. Acontecia uma coisa muito complicada, imagino eu, para o poder. As pessoas que circulavam e se mantinham ali em volta, trabalhadores de vários tipos, professores e estudantes e pessoas em geral também, estavam se acostumando com aquele clima de resistência e percebendo que havia uma ditadura e que havia alguma coisa para fazer, que havia alternativas. Mesmo o cidadão comum começou a se ligar um pouco nessas coisas... Esse foi um trabalho de irradiação política que a Faculdade de Filosofia realizou de uma maneira extraordinária. O custo foi sua saída de lá, a destruição do prédio que teve uma imensa carga simbólica e a vinda para a cidade universitária seguindo certos padrões que estavam sendo estabelecidos internacionalmente. No caso do movimento de 1968, na França, uma das medidas que o De Gaulle tomou foi essa de desorganização do lugar, jogando a universidade para pontos onde ela pudesse se tornar uma espécie de gueto, na qual as pessoas ficassem isoladas falando umas com as outras.
\end{abstract}

Arrigucci Jr. também enfatizou em suas lembranças o quanto a transferência da Faculdade de Filosofia para a cidade universitária foi prejudicial para o convívio entre os cursos e disciplinas oferecidos pela instituição. Em sua avaliação, os procedimentos pautados pela racionalização do trabalho acadêmico tinham o intento de escamotear interesses políticos:

No início da Maria Antônia, convivíamos com as Ciências Exatas, gente da Matemática, da Física, quer dizer, nos anos de 1970 havia algo parecido com o espírito da velha Faculdade de Filosofia fundada em 1934, que serviu de núcleo inicial da Universidade de S. Paulo. Nela havia de fato uma convivência entre as diversas ciências, exatas e humanas. Então o próprio ambiente e o tamanho facilitavam o contato entre as pessoas das diversas áreas e com colegas de áreas muito distintas. A cidade universitária começou por espalhar isso, a partir de espírito da divisão, da fragmentação. Há um lado nessa 
história que é a racionalização do trabalho, mas há também outra coisa, que é a separação e o impedimento da convivência entre áreas diferentes e do diálogo entre disciplinas que, na verdade, são segregados em blocos separados. Então a separação aqui teve um fito político, e houve uma dispersão nossa pelo campus da cidade universitária.

A destruição do prédio que abrigava a Faculdade de Filosofia na Rua Maria Antônia e, a posterior transferência para a cidade universitária que manteve desabrigados os cursos de Ciências Sociais, Filosofia e Letras, representam balizas características que compõem a memória coletiva docente. A vinda para o novo campus trouxe em seu bojo a necessidade da comunidade docente reconstruir a sua identidade diante da falta de infraestrutura, da fragmentação física e pedagógica dos saberes difundidos pela instituição. Além disso, pressionada por mudanças institucionais e de caráter profissional, precisou se recompor para resistir ao avanço do autoritarismo e, ao mesmo tempo, pensar alternativas para contribuir para as novas pautas trazidas pela (re)introdução da questão democrática.

\subsection{A Faculdade de Filosofia e a profissionalização da carreira acadêmica.}

Como a comunidade docente pesquisada foi forjada em um contexto de transição entre culturas universitárias distintas, suas carreiras apresentam características que combinam aspectos permeados por rupturas e continuidades. Nesse sentido, as entrevistas de história oral de vida acadêmica permitiram avaliar em que medida os docentes compartilharam memórias que mencionaram essas experiências singulares.

Fez-se necessário, além de palmilhar as sérias mudanças sofridas pelo espaço/tempo universitário, atentar para as especificidades de um processo de formação profissional em trânsito. Paradoxalmente, as mudanças que originalmente tinham o propósito de liquidar com a autonomia docente, propiciaram as condições necessárias para a rearticulação das forças de resistência. A nova carreira teria contribuído, assim, para o livre exercício da pesquisa e do ensino. Para a maior parte dos docentes, aliás, o novo regime de trabalho a que foram submetidos, representou na prática a universalização da estabilidade e a segurança de um plano de carreira. 
Os docentes entrevistados foram os primeiros a vivenciar integralmente o processo de profissionalização da pós-graduação implementado pelo regime militar e, posteriormente, aprimorado pela legislação do período democrático. Muitos trabalharam sem remuneração e iniciaram a carreira docente informalmente e, na maior parte das vezes, em regime parcial. A universalização do regime de dedicação integral à docência e à pesquisa (RDIDP) começou a se consolidar apenas depois de aprovado o novo Estatuto da Universidade de São Paulo em 1988.

A maioria dos docentes entrevistados ingressou como professor na Faculdade de Filosofia da USP sem ter concluído o doutorado. A carreira era feita a partir do auxiliar de ensino que correspondia ao graduado que era convidado pelo catedrático e começava a dar aulas e a cumprir tarefas propostas pelo mesmo. Uma vez concluído o mestrado, o auxiliar se tornava professor assistente e, obtido o doutorado, passava a professor assistente de doutor. Durante a fase inicial de profissionalização, prestaram alguns dos primeiros concursos públicos quando ainda eram mestres.

Coube a esses docentes se adaptarem ao novo modelo de carreira e atenderem às novas exigências em um momento crucial e sensível para a Faculdade de Filosofia, cujas vagas ociosas pertenciam, muitas vezes, a professores que tinham sido cassados pela ditadura. Não obstante, seriam os membros dessa mesma comunidade em transição os primeiros a galgarem a nova carreira composta a partir de 1988 em cinco escalas principais (Auxiliar de Ensino: MS-1; Assistente: MS-2; Professor doutor: MS-3; Professor Associado: MS-5; e Professor Titular: MS-6) alcançando o seu ápice como professores titulares, função anteriormente ocupada pelos catedráticos. Quando a cátedra foi extinta em 1968, o último degrau na carreira passou a ser a "titulatura" (MS6).

A intensificação do processo de profissionalização a partir dos anos 1980 pode ser observada nos números a seguir: Em 1980 havia 395 professores (82 MS1, 97 MS2, 142 MS3, 26 MS4, 23 MS5, 25 MS6), deste total, 220 trabalhavam em regime de dedicação integral (RDID), 84 em regime de turno completo (RTC) e 91 em regime de turno parcial (RTP). ${ }^{90}$ Em 1990 trabalhavam 442 professores na FFLCH-USP (41 MS1, 81

\footnotetext{
${ }^{90}$ No regime de Dedicação integral à docência e à pesquisa o docente deve dedicar 40 horas por semana às atividades de docência e pesquisa na universidade. No regime de turno completo (RTC) o docente obriga-se a trabalhar na Universidade de São Paulo por 24 (vinte e quatro) horas semanais em atividades de ensino, pesquisa e, quando necessário, extensão. Já no regime de turno parcial (RTP), o docente deve trabalhar na universidade por 12 horas semanais em atividades de ensino.
} 
MS2, 228 MS3, 43 MS5 e 49 MS6), sendo que 413 em regime de dedicação integral à docência e à pesquisa, 20 em regime de turno completo (RTC) e 9 em regime de tempo parcial (RTP). Em 2000 a FFLCH contava com 341 professores (7 MS1, 32 MS2, 212 MS3, 42 MS5, 48 MS6), sendo que 305 em RDIDP e 29 RTC. Em 2010, 485 professores trabalhavam na FFLCH, 98\% em regime de dedicação integral, sendo que 97\% eram doutores ou tinham formação acima. Além disso, 82 docentes inativos atuavam na pós-graduação orientando e/ou ministrando aulas.

A década de 1990 representou o ápice do período de transição em relação ao regime de trabalho docente na Faculdade de Filosofia. No início desta década praticamente $28 \%$ dos seus professores ainda não possuíam doutorado e, ao longo dela, uma grave crise se abateu sobre a instituição dado o grande número de professores que se aposentou temendo mudanças na lei previdenciária. A situação se agravou devido à interrupção de novas contratações, tendo o número de professores se reduzido a apenas 341 em 2000, um patamar bem abaixo dos 395 existentes em 1980.

As carreiras profissionais dos professores pertencentes à comunidade docente estudada, assim, situam-se entre o início da profissionalização e, o que pode ser considerada, a etapa mais madura desse processo. Dos dezenove professores titulares entrevistados, treze ingressaram como professores da Faculdade de Filosofia antes de concluírem o doutorado, são eles: Zilda Iokoi, Sandra Vasconcelos, Eunice Durham, José Álvaro Moisés, Francisco Oliveira, Leyla Perrone Moisés, Olgária Matos, Renato Janine Ribeiro, Mario González, Sandra Nitrini, Franklin Leopoldo e Silva, Wanderley Messias da Costa e Alessandri Carlos. Os docentes entrevistados, nesse sentido, possuem uma experiência singular porque alcançaram a "titulatura" durante um período de transição, no qual as características predominantes ainda não correspondiam às mesmas da fase final de consolidação do novo modelo universitário. Portanto, suas narrativas testemunham vivências de todas as etapas do processo de profissionalização transcorridas entre 1970 e 2010, e que resultaram na mudança de fisionomia da Faculdade de Filosofia.

A formação da comunidade docente estudada ocorreu mediante o avanço gradual da profissionalização das carreiras. $\mathrm{O}$ fato de muitos titulares terem convivido com o regime de cátedras e acompanhado sua lenta desestruturação - tendo iniciado suas carreiras como auxiliares de ensino, assistentes ou mestres -, permitiu a elaboração de avaliações críticas em relação ao processo e, na medida do possível, o desenvolvimento 
de formas de resistência no cotidiano. O compromisso com a qualidade das pesquisas e do ensino ministrado na instituição, bem como o bem público, tornou possível evitar que os princípios tecnicistas que pregavam a mercantilização da vida acadêmica atingissem todos os seus fins. Além disso, o fato de terem iniciado suas atividades de ensino muito jovens e em condições precárias, contribuíram para uma avaliação crítica, mas, ao mesmo tempo, equilibrada em relação à institucionalização universitária.

Como já obervado, as alterações ocorridas nas carreiras docentes e nos regimes de pós-graduação foram parte de um processo de transformações econômicas em escala mundial, cujos efeitos foram mais nítidos em cidades globais como São Paulo, e atendiam a demandas mercantilistas. Reconhecer a institucionalização da carreira docente, no entanto, não significa reduzir os professores que experienciaram esse processo, aos seus desígnios imediatos. Nem as universidades públicas no contexto brasileiro e, muito menos os seus docentes, acataram na íntegra as suas propostas, principalmente, aquelas de teor conservador. Aliás, vale ressaltar que a profissionalização da carreira docente e a otimização dos recursos universitários estavam presentes na pauta de reivindicações do movimento estudantil e de professores da universidade de São Paulo no contexto do golpe civil e militar de 64. No entanto, as mudanças defendidas pelos professores e alunos estavam ligadas à valorização da docência e ao fortalecimento da autonomia da universidade pública.

Florestan Fernandes teceu uma das mais propositivas defesas da racionalização da vida universitária em diferentes exposições públicas e artigos apresentados na primeira metade de 1968. Para este autor, era imperativo conduzir a academia no país através de um processo que a levaria do estado de simples ensino superior, para um padrão verdadeiramente universitário. Entre outras questões, Florestan ressaltava a importância de se superar os limites impostos pelas escolas superiores existentes e reivindicava com urgência a organização de universidades capazes de orientar o desenvolvimento da ciência no Brasil:

O primeiro traço essencial refere-se ao modo de selecionar e de utilizar os recursos materiais, financeiros e humanos, mobilizáveis para fins de ensino e de pesquisa de nível universitário. Nesse capítulo, a situação atual é de desperdício crônico ou de subutilização normal dos recursos mobilizados socialmente. Uma vasta gama de recursos, que não custam dinheiro ou que poderiam ser mobilizáveis sob os custos vigentes, são pura e simplesmente negligenciados. Eles não penetram na consciência pedagógica dos professores ou, se isso 
acontece, eles não são compatíveis com as técnicas pedagógicas exploráveis a partir da estrutura de cátedra, da escola superior ou da universidade conglomerada. De outro lado, como o horizonte pedagógico médio não se organiza com vista a funções intelectuais múltiplas, tudo gira em torno de um ensino morto e vazio, predominantemente verbalista, "erudito" e divorciado do pensamento inventivo. A universidade integrada e multifuncional requer, como ponto de partida, a organização racional das relações entre meios e fins. Por isso, ela pressupõe e conduz ao aproveitamento sistemático dos recursos financeiros, materiais e humanos disponíveis do ambiente, procurando mobilizá-los sob condições de crescente controle racional dos graus de eficácia obtidos em sua utilização ${ }^{91}$.

A proposta de Florestan Fernandes tinha como horizonte a autonomia econômica e política do país através do desenvolvimento de sua ciência e tecnologia. Ele próprio constatou que a dificuldade em se criar uma universidade integrada e multifuncional, seria "mais um processo cultural que um problema de financiamento". Principalmente pelo fato dos catedráticos possuírem "um poder ilimitado e autoritário de decisão". Era preciso, nesse sentido, “descomprimir as funções de decidir, administrar e dirigir; de outro, é necessário transferir para unidades básicas e intermediárias ou para serviços de administração e de controle, propriamente ditos, o poder fundamental de decisão e de mando"92.

O fato de pertencerem a uma comunidade formada em um contexto de transição política no âmbito nacional e, econômica, na esfera internacional - permitiu aos docentes não só uma avaliação crítica das inovações implementadas, como também a capacidade de resistir e moldar novas possibilidades de atuação profissional. Se as medidas impostas pelos militares dialogavam com as demandas e as transformações na ordem econômica mundial, internamente a comunidade docente procurava galvanizar as mudanças em benefício da regularização e valorização da carreira. Portanto, há uma diferença significativa entre as propostas de modernização da universidade, aquela defendida pelos militares e baseadas em proposições liberais e conservadoras estabelecidas a partir da Lei $5540 / 68^{93}$ - e, outra, vinculada a luta travada por setores progressistas pelo fim da cátedra.

\footnotetext{
${ }^{91}$ FERNANDES, F. “Escola superior ou universidade?". In: FERNANDES, F. Universidade brasileira: reforma ou revolução? São Paulo: Alfa-Omega, 1975, p.86.

${ }^{92}$ Idem, p.88.

${ }^{93}$ Nas palavras de Luiz Antônio Cunha, a profissionalização teve início com a proposta e tentativa de mercantilização da vida acadêmica: "o golpe de 1964 abriu caminho para a ascensão de um novo tipo de pensador da educação no país, como, de resto, em todas as áreas da administração pública: o economista. Esse personagem, muitas vezes graduado em engenharia, travestido de filósofo e pedagogo, traduzia
} 
Muitos docentes falaram a respeito do período em que conviveram com o regime de cátedras e de seu relacionamento com os catedráticos. O sistema de cátedras, durante as entrevistas, consistiu em objeto de avaliações ambíguas: ao mesmo tempo em que pesquisas e orientações eram valorizadas, críticas foram elaboradas contra a vitaliciedade e a concentração de poder dos responsáveis pelas cadeiras. De modo geral, houve um consenso entre os entrevistados quanto à manutenção de muitas práticas tradicionais, mesmo após a promulgação da nova legislação. Ainda nos anos 1970 e início dos 1980, alguns catedráticos - que tinham se tornado, na prática, os "donos das cadeiras" - continuavam sendo os responsáveis pelas principais decisões. As entrevistas também endossaram o que Florestan Fernandes já havia antevisto nos anos 1960; a otimização e a democratização das atividades universitárias dependiam de mudanças culturais que não se estabeleceram imediatamente após a decretação do fỉm do regime de cátedras. Nesse sentido, a profissionalização da carreira impulsionou decisivamente a construção da autonomia docente e, ao mesmo tempo, sinalizou novas possibilidades de atuação pública.

As entrevistas realizadas revelaram ainda que a comunidade docente vivenciou intensamente o infindável período de transição entre o fim das cátedras e, de fato, o término do poder exercido pelos catedráticos. A transição entre o regime de cátedras e a institucionalização dos concursos prolongou-se devido às medidas de exceção impostas pelo governador Paulo Maluf (1979-1982) que, eleito indiretamente e comprometido com a ditadura civil-militar, determinou a investigação e exoneração de funcionários públicos e restringiu a realização de concursos para ingresso nas universidades estaduais. Por isso, alguns docentes entrevistados que ingressaram na USP nesse contexto, foram admitidos através de seleções internas, enquanto outros puderam prestar concursos apenas após o final de seu mandato "biônico". O início do processo de profissionalização propriamente dito e realizado a partir de concursos públicos para a efetivação de docentes tornou-se obrigatório e passou a ocorrer sistematicamente,

todas as questões educacionais em termos de custos e benefícios. O processo educacional era associado à produção de uma mercadoria que, como todo processo econômico, implicava em um custo (os gastos efetuados) e um benefício (algo similar à receita auferida pela venda da mercadoria). O benefício poderia ser expresso apenas em número de alunos promovidos ou formados, durante um certo tempo (análogo ao número de peças por hora...) ou, mais sofisticadamente, ao diferencial de salário supostamente acrescido como resultado do conhecimento adquirido. Pois bem, para o engenheiro/economista daquela onda tecnocrática, racional era tudo que levasse à maximização do rendimento do processo educacional". Ver: CUNHA, L. A. "Racionalizar para não sobrar". In: CUNHA, L. A. A universidade reformanda. Op. cit, pp. 257-258. 
apenas após a promulgação da Constituição de 1988 e da aprovação do novo estatuto da universidade.

Desde o início do trabalho de campo os testemunhos dos professores titulares evidenciaram que, para a memória coletiva da comunidade pesquisada, a profissionalização da carreira docente agregou benefícios à universidade no que diz respeito ao fim das condições precárias de contratação e ao regime de trabalho. Isso não significa que, para os docentes, a implantação da nova carreira ao longo dos anos 1970, 1980 e 1990 tenha ocorrida de maneira congruente, progressista e desburocratizada. Pelo contrário, muitos professores ressaltaram em suas falas a sobrecarga de trabalho e as novas responsabilidades burocráticas que se somaram às novas etapas do processo de profissionalização das carreiras. Os aspectos problemáticos da fase de consolidação da profissionalização docente nos anos 1980 e 1990, também apontados pelos professores, serão discutidos a seguir.

Por hora, cabe pontuar a iniciativa dos colaboradores em estabelecer um contraste entre o início de suas carreiras nos anos 1970 e os dias atuais. As considerações de Perrone-Moisés e de outros professores, demonstram que a carreira docente propriamente dita não era um fato concreto para a comunidade docente até o início dos anos 80. A professora lembrou que a carreira acadêmica não podia ser plenamente planejada pelos pós-graduandos que, sequer podiam saber se seriam contratados em caráter permanente, em quais condições isso ocorreria e se o trabalho oferecido seria remunerado. Afinal, além de não ter recebido salário algum pelo primeiro ano e meio de atividade, Perrone-Moisés somente conseguiu ser contratada em regime de tempo integral após a livre docência. Em entrevista realizada, a professora relatou as dificuldades atravessadas nos primeiros anos de trabalho na FFLCH-USP, quando vivenciou o início do processo de transição na carreira universitária uspiana:

Veja como as coisas evoluíram para melhor, na USP: durante um ano e meio trabalhei de graça, porque não havia verba para a contratação de novos professores. Havia uma vaga deixada por uma professora que estava na Europa, mas a contratação era complicada. Então, em 1970, eu dava aula de literatura francesa em três lugares: na PUC, na USP e no secundário do Colégio Sion. Antes do convite, eu não tinha nem projeto de fazer carreira acadêmica. Eu não pensava em escrever uma tese, estava satisfeita fazendo jornalismo cultural. Mas tendo entrado na carreira, defendi minha tese de doutorado em 1971. Continuei dando aulas e, em 1975, defendi a Livre Docência. Somente depois da Livre Docência passei a ter tempo integral, antes tinha 
apenas tempo parcial. Isso também era dificílimo naquela época. A gente tinha que esperar muito. Então para mim foi muito difícil economicamente esse começo. Eu estava divorciada e com duas filhas, então tinha que trabalhar bastante.

Tendo uma carreira acadêmica típica dessa fase de implantação das novas normas e, fazendo parte dessa comunidade em transição, desenvolveu a livre docência na França entre 1972 e 1975 com o apoio de uma bolsa da FAPESP; inaugurando o período em que os pesquisadores da FFLCH-USP e, de modo geral, todos os brasileiros deixaram de contar apenas com as bolsas cedidas pelos governos europeus.

Os docentes em questão que vivenciaram o período inicial do processo de profissionalização acadêmica imposto pelos militares, afinal, conviveram durante muitos anos com a vigência de regimes informais de trabalho: muitos deles iniciaram a carreira docente como auxiliares de ensino e, portanto, eram professores que trabalhavam na USP sem qualquer remuneração.

González também relatou detalhes dos momentos iniciais de sua carreira na USP. A insegurança do ponto de vista trabalhista mantinha os professores contratados de forma precária na dependência das decisões tomadas efetivamente pelos docentes que, na prática, continuavam sendo os catedráticos responsáveis por administrar os novos departamentos:

Havia, inclusive, um caminho para entrar na USP, que era
necessariamente começar a dar aulas de graça. Na época se chamava
instrutor voluntário. Todo mundo passava por essa etapa, dando aulas
de graça até ser contratado. Não havia concurso, não havia nada,
prevalecia a vontade do catedrático. Inclusive não havia mais cadeira
porque havia sido extinta com a Reforma, mas os antigos catedráticos
conservaram o poder e, na prática, o exerciam. O Departamento, na
prática, era uma reunião de catedráticos que decidiam em conjunto o
que eles queriam. Isso durou durante todos os anos 1970. Em Letras
Modernas continuamos sendo uma reunião de cadeiras com os
catedráticos tendo a última palavra em tudo.

Messias da Costa relembrou com bom humor os anos de atuação como docente voluntário na FFLCH-USP:

Depois que me formei, entrei no mestrado. Passei a colaborar com o Prof. Armando Corrêa da Silva na medida em que dava aulas de geografia como docente voluntário para as Ciências Sociais. Não se ganhava nada. Nesses moldes, hoje existe o Programa de 
Aperfeiçoamento de Ensino (PAE-USP). Essa foi uma enorme experiência, afinal dei três anos de aulas juntamente com o Prof. Antônio Carlos Robert de Moraes que era meu parceiro naquela época. Os estudantes gostavam muito de ter aulas com outros estudantes... Uma vez, lembro que fizeram uma avaliação dos professores e eu e o Tonico fomos poupados de críticas mais severas... Apareceu em um dos murais da faculdade uma charge com uma dupla caipira tocando viola e estava escrito assim: "Tonico e Tinoco cantando: Ai que saudades do marxismo!". Era muito divertido, nós riamos muito...

No entanto, a experiência e o reconhecimento do trabalho por parte dos alunos tinham que ser complementados com trabalhos remunerados que eram realizados em horário trocado. Além da conquista de certo prestígio acadêmico, não se ganhava nada com a docência voluntária. A única compensação conquistada posteriormente foi o acréscimo no tempo de serviço à época da aposentadoria.

Havia casos também, como narrado por Abdala Júnior, nos quais os alunos que recebiam bolsa eram utilizados para ocupar vagas em caráter provisório e adiar a contratação de professores, prejudicando os cursos:

Passei a lecionar aqui na USP como instrutor voluntário porque tinha bolsa FAPESP. Naquela época eles aproveitavam justamente os bolsistas para lecionar. Trabalhei um ano como instrutor voluntário, depois a FAPESP resolveu proibir que se fizesse isso, já que era uma forma da USP não contratar docente. Enquanto se valia dos bolsistas da FAPESP, não contratava professores. Só continuei na USP porque acabei fazendo um concurso de ingresso para professor universitário.

Até meados dos anos 1980 o processo de profissionalização da carreira docente ainda se encontrava em uma fase inicial na qual poucos professores começavam a trabalhar em regime de dedicação exclusiva. O ingresso de Abdala Jr. como professor no Departamento de Letras Clássicas e Vernáculas, por exemplo, ocorreu em regime de tempo parcial, o que impossibilitava a realização de pesquisas e obrigava o mesmo a dar aulas em colégios particulares para preencher a carga horária semanal.

O caráter transitório da comunidade docente pesquisada pode ser constatado ainda em testemunhos como o de Janine Ribeiro que narrou como se deu seu ingresso na USP como professor em 1976: "Na época em que ingressei na USP como professor, não havia concurso. Passei por um processo de contratação no qual os departamentos escolhiam os professores. Os concursos não passavam pela cabeça de ninguém”, afirmou Janine Ribeiro. 
Nitrini também contou a respeito de como os catedráticos escolhiam seus assistentes e futuros professores da instituição. Naquele contexto, foi chamada pelo catedrático Albert Audubert em 1970 para dar aulas no curso de Francês da Faculdade de Filosofia, Letras e Ciências Humanas que estava funcionando nos barracões da Cidade Universitária. Fez o mestrado com bolsa do governo francês, na época em que Albert Audubert desempenhava um papel de intermediação entre o governo francês e os alunos interessados em estudar na França:

Em 1970 parti para a França como bolsista do governo francês. O governo francês tinha uma política de conceder bolsas para estudantes do mundo inteiro, incluindo a América Latina. As solicitações de bolsa eram encaminhadas diretamente para o Consulado Francês, com um projeto de pesquisa. Na Faculdade de Filosofia, Ciências e Letras, o Prof. Audubert exerceu um papel importante como intermediário entre os estudantes que postulavam a bolsa e o consulado. Ele observava os estudantes, aproximava-se dos que mais se destacavam, lhes perguntava se queriam estudar na França e os encaminhava para o consulado. A demanda era grande no Brasil todo, havia um processo de seleção central, mas, em geral, os candidatos indicados pelo Prof. Audubert eram contemplados com a bolsa. Além da indicação do professor Aubert Audubert, contei também com muito apoio da Madame Baudet, professora da Aliança Francesa, onde estudei por sete anos, desde meu primeiro ano do clássico até o último ano de Faculdade.

Nitrini relatou também detalhes sobre esse período de grande informalidade no mundo do trabalho uspiano. Além de passarem por um processo de contratação precário, havia uma extrema dificuldade em conseguir o tempo integral para o exercício pleno das atividades acadêmicas. Segundo a professora, em 1981 houve concurso em Teoria Literária e Literatura Comparada e um processo seletivo em Língua Francesa no Curso de Letras da FFLCH:

Naquela época a gente podia prestar o concurso como mestre. Teoria Literária e Literatura Comparada fazia parte do antigo Departamento de Linguística e Letras Orientais. Primeiro Linguística tornou-se Departamento. Os professores da Área de Teoria Literária e Literatura Comparada também tinham o projeto de criar um Departamento. Pensando já em 1981 na criação de um Departamento, os professores da Área de Teoria incentivaram doutorandos, além de doutores recentes, a prestarem o concurso, com a perspectiva de se ter uma equipe de reserva. Esse concurso foi aberto para oferecer a possibilidade de professores da casa se efetivarem, como Davi Arrigucci Jr., o saudoso João Luís Lafetá e Ligia Chiappini Moraes 
Leite. Havia uns 13 candidatos. Dentre os candidatos de fora, fiquei em terceiro lugar. A primeira foi Iumna Maria Simon, que já era doutora. O segundo foi o Fulaneti, mestre e eu, a terceira, também mestre. Contando todos os candidatos, obtive o sexto lugar.

Conforme os relatos de alguns docentes, somente a partir dos anos 1980 a situação profissional de muitos colegas foi regulamentada mediante a abertura e realização de concursos públicos. Nitrini também reportou que o ingresso na universidade através do novo modelo de contratação, não garantia o acesso imediato ao regime de dedicação exclusiva. Aprovada em concursos realizados para diferentes áreas, a professora começou a dar aulas no Departamento de Letras Modernas e, mais tarde, também acabou chamada para a vaga de Teoria e Literatura:

Quando fui ao setor de serviço pessoal da reitoria para entrar com os papeis para pedir minha demissão do Departamento de Letras Modernas, informaram-me que eu poderia ficar nas duas áreas, Teoria Literária e Língua Francesa, porque ambas eram em período parcial. Então fiquei ainda durante algum tempo em período parcial dando aula de Língua Francesa e de Teoria Literária. Eu dizia que num determinado dia da semana eu virava o botão, num dia eu dava Teoria Literária, no outro, Língua Francesa. Naquela época a maioria dos professores tinha período parcial. Havia fila para se obter período integral. Os professores de hoje não podem imaginar o que significava a gente ficar na fila para obter o período integral! Então entrei nessa fila.

Com o mestrado, Nitrini voltou ao Brasil, prestou concurso e passou a dar aulas de Língua e Literatura Francesa na Faculdade de Filosofia, Ciências e Letras de Assis, onde trabalhou entre 1974 e 1979. Pediu demissão em agosto de 1979 para trabalhar no doutorado com uma bolsa da FAPESP. Prestou um concurso público para Teoria Literária e Literatura Comparada e um processo seletivo para Língua Francesa. Nesta época, a Prof. a Sandra lembra que o Prof. Davi Arrigucci Júnior ainda não era efetivo, bem como a Prof. a Lígia Chiappini e o Prof. João Luís Lafetá. Em sua fala, chama atenção o fato de os professores convocarem os alunos para prestar o concurso com vistas à estruturação de um quadro docente de reserva que seria utilizado para a criação do futuro Departamento de Teoria Literária e Literatura Comparada. Isso mostra o quanto o processo de profissionalização é um fato marcante para aqueles que vivenciaram as mudanças na universidade pública ocorridas entre os anos 1970 e 1980. 
Alessandri Carlos relembrou os primeiros anos de trabalho na Faculdade de Filosofia, destacando que a maior parte dos professores ingressava na carreira acadêmica antes de concluir o doutorado. Segundo a professora, essa característica comum ao período de transição profissional vivido por sua geração, contribuía para que os ingressantes mantivessem um contato mais próximo com os alunos de graduação:

\begin{abstract}
Nesse contexto a gente podia estudar. Nós tínhamos aqui no Departamento de Geografia um grupo de professores ingressos como mestres. Isso foi da maior importância porque ter perdido os mestres e ter colocado a carreira para doutor foi uma grande perda. Afinal, quando você é professor mestre, não trabalha e não orienta na pósgraduação. Dávamos um curso de oito horas na graduação e isso nos permitia completar uma carga horária na graduação cuidando e orientando os alunos. Então quando entrei como professora nessa faculdade em 1982, imediatamente montei um grupo de dez alunos que foram se formando junto com a minha própria formação enquanto professora e na prática. Três desses ex-alunos são hoje professores do Departamento de Geografia. Então pude formar alunos e me dedicar à graduação, construir grupos de estudos na graduação e cuidar da sua formação.
\end{abstract}

Na segunda metade dos anos 1970, o regime de dedicação integral à docência e à pesquisa (RDIDP) não era uma realidade para a maioria dos professores. Isso significa que a profissionalização da carreira acadêmica na USP foi sendo construída paralelamente à própria carreira dos professores que se tornariam os primeiros titulares, segundo as regras do novo regime acadêmico, a substituírem os antigos catedráticos. Nesse sentido, os primeiros que se profissionalizaram plenamente nos novos moldes do regime departamental estabelecido pela Lei 5540/68, são aqueles que fazem parte da comunidade estudada. Eles foram responsáveis por avaliar as mudanças e planejar a própria carreira concomitantemente ao processo de implantação dessa nova realidade acadêmica: a atuação como professores pesquisadores, inicialmente em regime parcial de trabalho e, posteriormente, em regime integral e mediante dedicação exclusiva. Coube a esses professores entender como se organizavam os novos investimentos estatais em pesquisa e relacioná-los à atividade docente. Nessa fase de transição, muitos entrevistados começaram a atuar como professores precocemente, esse fato pode ter contribuído decisivamente para a valorização do trabalho em sala de aula, inclusive na graduação, bem como na formação de importantes grupos de pesquisas. 


\title{
1.7 Uma comunidade acadêmica forjada entre duas culturas políticas.
}

\begin{abstract}
Há uma coisa que alguns intelectuais brasileiros têm que não se encontra em lugar nenhum do mundo: raramente, na própria América Latina, podem-se identificar figuras como Antônio Cândido, Sérgio Buarque de Holanda (devo incluir também o Florestan Fernandes). Eles não têm sido apenas bons acadêmicos, professores e orientadores de teses... Sobretudo, acho importante dizer que fundaram escolas de estudos... Isto tem muito a ver com o calor humano e suas altas convicções morais... Ainda que a modéstia deles oculte o alcance de suas obras, eles fizeram algo que vai continuar. ${ }^{94}$
\end{abstract}

Os professores pesquisados pertencem a uma comunidade docente peculiar porque estruturada entre duas culturas universitárias e, não obstante, formada no contexto de transição da ditadura para a democracia política. Influenciados por questões e princípios próprios à construção do regime democrático - consolidado nos dias atuais em sua forma política -, os relatos indicaram a presença na memória docente de um projeto coletivo de resistência à ditadura que, ao mesmo tempo, combinava rigor intelectual e agudo potencial de questionamento político. Algumas entrevistas ressaltaram também que as tensões que se abateram sobre a universidade forjaram professores preocupados com a sua própria condição intelectual e com o papel a ser desempenhado pela universidade pública em uma democracia. Desenhava-se, assim, uma condução específica do trabalho acadêmico diante de uma perspectiva intrincada e balizada entre a resistência à ditadura e a necessidade de contribuir para o processo de redemocratização. Somava-se a isso, a necessidade de coibir a transformação da universidade em um simples instrumento político e, seus intelectuais, em produtores de pesquisas para oferecer aportes ideológicos com o intuito de sustentar posições de grupos políticos específicos ou de interesses privados.

Leopoldo e Silva enfatizou o drama vivido pela comunidade docente pressionada entre o avanço do autoritarismo sobre a universidade e a necessidade de manter a instituição em funcionamento. Tratava-se de um grupo de jovens pós-graduandos que tiveram de manter as pesquisas acadêmicas e os departamentos em funcionamento, às vezes, sem seus antigos orientadores. Além disso, o fato de alguns terem assumido cargos ou ingressado em linhas de pesquisas que, anteriormente, eram administrados

\footnotetext{
94 Entrevista de Richard Morse à José Carlos Sebe Bom Meihy. In: MEIHY, J. C. S. B. Colônia brasilianista - História Ora de Vida Acadêmica. São Paulo: Nova Stella, 1990, p.161.
} 
pelos mestres cassados, acarretava cobranças, responsabilidades e tarefas que também tinham, por sua vez, evidente conotação política:

\begin{abstract}
Acompanhei muito essas discussões, em quase todas as assembleias a questão da universidade aparecia com muita força e criava situações difíceis para cada um de nós. Pelo simples fato de você estar na universidade onde os seus mestres haviam sido cassados... Somente por isso você poderia ser considerado um traidor. Não por outra pessoa, mas por si mesmo. De qualquer maneira, nós éramos muito incentivados pelos próprios professores cassados que diziam: "Vocês tem que continuar! Tem que manter a universidade...". Mas, enfim, sempre teve uma ambivalência em relação a isso. E a gente era sempre solicitado a tomar posições muito diferentes e opostas.
\end{abstract}

Nesse sentido, o sentimento de pertencimento à comunidade docente pesquisada foi apregoado por Adorno que ressaltou justamente o fato dos professores terem conservado uma tradição acadêmica através das aulas, orientações e pesquisas, dando continuidade ao trabalho daqueles que haviam sido cassados. Adorno compreende que sua própria trajetória acadêmica é parte de um projeto consciente de formação, que atuou na preservação dos conteúdos curriculares, das hipóteses e das preocupações teóricas formuladas pelos antigos mestres:

Fiz o curso de Ciências Sociais que, se por um lado, aconteceu em uma época muito trágica porque vários professores tinham sido cassados, havia aqueles que ficaram e que eram excelentes professores. No entanto, é preciso reconhecer que estes estavam assumindo uma herança muito pesada. Imagine esse grupo de jovens professores que hoje são meus colegas aqui na FFLCH e que, de repente, tiveram que substituir um Florestan Fernandes, um Fernando Henrique?... Não foi fácil. Agora, tiveram também uma formação tão boa que foram capazes de sustentar aquele legado e transmitir para os outros. Eu mesmo não fui aluno do Florestan, mas eu me sinto nessa geração porque havia o mesmo rigor, o mesmo compromisso com a ciência que aprendi.

Observa-se, portanto, a consolidação de uma postura intelectual que fundia concepções rigorosas de trabalho científico, compromisso institucional com o bem público e responsabilidade política e social. A comunidade estudada teve, assim, o encargo de assumir precocemente o peso de uma dupla responsabilidade do ponto de vista institucional: era preciso manter o potencial crítico do trabalho acadêmico diante 
das perseguições políticas impostas à Faculdade de Filosofia e do avanço do processo de profissionalização que alterava aos poucos a fisionomia da universidade.

Não obstante, segundo Franklin de Oliveira, o contexto ditatorial forjou uma comunidade docente forçada a assumir posicionamentos políticos que tiveram implicações decisivas na formação intelectual de seus componentes:

\begin{abstract}
A travessia desse período, do ponto de vista político, foi muito difícil, mas extremamente rica. Estava em jogo nessas opções e nesses conflitos não só as questões da política objetiva, mas de cada um enquanto pessoa, enquanto sujeito. A vivência disso foi muito interessante porque as pessoas tinham que resolver esses problemas. Era parte de uma espécie de dever político que muitos achavam que existia e que tinha que ser cumprido e que, afinal, era posto pela situação. Ninguém tinha escolhido aquilo. Ao mesmo tempo essas questões te envolviam existencialmente, pessoalmente, e tinham que ser contrabalançadas. Isso enriqueceu muito a minha geração. É algo que me emociona muito até hoje... Mas isso foi se perdendo com o tempo. Passou-se a ter uma visão muito objetiva da política. A política como sendo uma coisa a ser feita. Isso é complicado porque tem consequências... Às vezes, essa ambiguidade que foi presente na minha geração, deu a ela um perfil e uma consistência. Enfim, era uma situação dramática, com muitas oscilações. Ao mesmo tempo, permitiu que as pessoas abrissem os horizontes.
\end{abstract}

A transição democrática acarretou a costura de novos laços com a sociedade civil que passaram a caracterizar fortemente a comunidade docente estudada. As experiências compartilhadas ao longo do processo de transição trançada e aquelas vivenciadas no contexto da ditadura (as formas de repressão e resistência, as prisões, a tortura, o trauma) foram essenciais para a construção de uma nova relação com a sociedade civil. A união forjada na oposição ao governo ditatorial, aos poucos daria lugar às divergências próprias da busca pela concretização de um regime democrático. $O$ dissenso não só tomaria a praça pública, mas atingiria diretamente a FFLCH-USP.

Solicitados a responder questões pertencentes à política objetiva durante o período de redemocratização política, os docentes passaram a se envolver com as novas possibilidades de exercício da cidadania e de participação efetiva no espaço público, redesenhando o papel dos intelectuais. Espremida entre o desejo de conservar as principais tradições humanistas e, concomitantemente, enfrentar as novas exigências do seu tempo, a segurança de uma carreira acadêmica pública passou a ser considerada uma possibilidade de desenvolver uma atividade docente segura, longeva e independente. 
Em se tratando de uma comunidade situada entre duas culturas acadêmicas e formada em meio a uma transição política em curso, os docentes a ela pertencentes assumiram o processo de profissionalização determinado pela aliança MEC-USAID, sem perder de vista, contudo, as bandeiras históricas e progressistas defendidas por diversos movimentos discentes e docentes já citados e avalizados pela ADUSP a partir de 1976.

A hipótese que norteou a pesquisa e será explicitada nos próximos capítulos, parte da premissa de que a comunidade docente em questão resistiu intensamente às agruras e adversidades ligadas ao processo de transição de um regime de pós-graduação para outro, aqui denominado de profissionalização. Considerando as restrições impostas pela nova carreira docente, acredita-se que a institucionalização foi capaz de reforçar o compromisso dos docentes em relação ao ensino público, garantindo ainda uma posição de independência política e autonomia intelectual.

O contexto de redemocratização viria ainda tingir esse panorama transitório com novas perspectivas políticas e possibilidades de atuação intelectual. Quando a ditadura deixou de representar o perigo mais iminente, as diferentes forças que estavam unidas para resistir ao autoritarismo foram se dissipando em várias alternativas políticas e comportamentos intelectuais variados. Nascia a responsabilidade de contribuir de forma efetiva para a redemocratização, através da análise do conjunto de forças sociais e políticas. Além disso, surgia a necessidade de reestruturação do espaço público, de elaborar estratégias que visassem o fortalecimento das instituições democráticas e o surgimento de propostas e projetos políticos divergentes.

A seguir, examinar-se-á o comportamento de uma comunidade docente em franco processo de transição trançada, quando convocada pela sociedade para o diálogo. A (re)introdução da questão democrática motivou os membros dessa comunidade docente a desempenhar diferentes papéis, sem permitir, contudo, que a carreira docente fosse relegada a um segundo plano. O novo contexto político trazia em seu bojo a possibilidade de encontro entre as reivindicações sociais e o trabalho intelectual o que, para Florestan Fernandes, é exatamente o que oportuniza a elaboração de uma atuação docente frutífera:

Na verdade, a relação do cientista social com a sociedade depende muito do modo pelo qual a sociedade procura a contribuição do cientista social. (...) Os que criticam muito o intelectual e esperam 
demais dele, isoladamente, esquecem-se que o intelectual, ele próprio, possui as mesmas limitações. Ele pode avançar, se ele estiver sob uma determinada pressão, se ele estiver sendo utilizado $^{95}$.

No próximo capítulo a atividade intelectual desenvolvida pela comunidade docente, como sugerido por Florestan Fernandes, será avaliada dialogicamente. Afinal, os intelectuais são fruto de determinadas relações sociais e do modo como os cidadãos constroem o espaço público. Desse modo, serão investigadas as novas formas de atuação e as responsabilidades assumidas pelos professores universitários diante da consolidação da democracia política no país e da profissionalização da vida acadêmica.

\footnotetext{
${ }^{95}$ FERNANDES, F. A condição de sociólogo. São Paulo: Hucitec, 1978, p. 152-153.
} 


\title{
Capítulo 2: Uma comunidade docente em transição no contexto democrático.
}

\begin{abstract}
A primavera cultural brasileira não sucumbiu aos tempos invernais do AI-5. Involuntariamente, a censura, a repressão e o controle social e político acabaram por dar uma importância renovada à vida cultural, espaço no qual a expressão crítica, mesmo que alegórica ou metafórica, ainda era possível. Convivendo com o mercado, à sombra dele ou completamente inserida nas grandes estruturas de produção, a cultura brasileira de viés crítico foi uma espécie de "educação sentimental" dos jovens, sobretudo na direção de valores democráticos e libertários. Se não fez a revolução nem derrubou a ditadura com a força das canções, filmes e peças, alimentou a pequena utopia democrática que ganharia as ruas e daria o tom das lutas civis a partir de meados dos anos $1970^{96}$.
\end{abstract}

Talvez o amadurecimento tenha sido mesmo no carbureto e nunca tenha passado de uma produção de "protesto"; ou os intelectuais, mestres da ilusão, confundiram prestidigitação com o real; pode ser que a comparação com os períodos anteriores levasse a superestimar a produção corrente; ou se trata de fenômeno mais complexo e mais grave, que tem a ver com a nova posição do intelectual na estrutura social, suas relações com as outras classes, com a produção de mercadorias (inclusive a cultural), com a política e finalmente com o Estado; pois o fato é que os intelectuais estão abandonando as suas pesquisas, suas salas de aula, seus laboratórios, para transformarem-se em gestores do poder: migrando para o controle da burocracia da pesquisa, para postos governamentais nos níveis federal e estadual. Mais: a arma da crítica foi gradualmente sendo posta de lado, substituída por uma subliteratura apologética, justificada pelo papel do intelectual na construção da democracia e pelos riscos a que essa "novidade" está sujeita ${ }^{97}$.

Nos anos 70 bastava saber-se o que não se queria. Nos anos 80 , a que se revelar o que se pretende, sob o risco de, se assim não o fizer, ser o intelectual hesitante atropelado por uma avalanche de definições categóricas e passar a residir num certo limbo cultural, que também já aponta em estado embrionário ${ }^{98}$.

\footnotetext{
${ }^{96}$ NAPOLITANO, M. 1964 - História do Regime militar brasileiro. Op. cit., p.204.

97 OLIVEIRA, F. "Aves de Arribação: a migração dos intelectuais". Lua Nova, vol.2, n .3, São Paulo, Dec. 1985, pp.20-26.

${ }^{98}$ Entrevista de Julio Cesar Monteiro Martins à Heloisa Buarque de Hollanda. Ver: GASPARI, E. \& VENTURA, Z. \& HOLLANDA, H. B. de. Cultura em trânsito 70/80: da repressão à abertura. Rio de Janeiro: Aeroplano, 2000, p.158.
} 


\subsection{Os intelectuais e a (re)introdução da questão democrática.}

A universidade como eixo de pesquisa, produção e irradiação de saberes e conhecimento encontra-se diante de uma interrogação contemporânea por excelência - a democracia ${ }^{99}$.

A (re)introdução da questão democrática no Brasil, ocorrida em plena vigência do Estado autoritário, contribuiu para a definição de novas relações entre a comunidade docente da FFLCH-USP e a sociedade. Conduzida através das lutas populares que envolveram movimentos sindicais, greves operárias, Congressos Contra a Carestia de Vida apoiados pelo Movimento Eclesial de Base e organizados pela Igreja Católica, e seguida ainda por mobilizações em torno da Campanha da Anistia aos Presos e Exilados Políticos, a democratização política também contou com a colaboração e a participação de intelectuais que fomentaram um rico debate ${ }^{100}$. Enquanto os movimentos sociais e novos personagens entravam em cena trabalhando pela reconstrução do espaço público, começavam a ser redigidos por alguns intelectuais os primeiros textos responsáveis pela discussão e problematização da questão democrática no país. Diferentes programas e sistematizações a respeito de um possível retorno à democracia política começaram a dar contorno a docentes atentos e preocupados em encontrar novos espaços de atuação dentro e fora da universidade.

A participação dos professores nos debates em torno da (re)introdução da questão democrática foi fundamental para o amadurecimento de possibilidades de ação na nova conjuntura política que se desenhava. Alguns intelectuais se aproximaram dos debates e colaboraram diretamente na organização de novos partidos políticos, outros mantiveram uma posição independente e preferiram cuidar de questões acadêmicas, desempenhando um trabalho intramuros, mas não menos político. As novas propostas em torno da democracia estimularam o amadurecimento da participação intelectual, fosse em ações político-partidárias mais explícitas, em atividades silenciosas no interior da universidade ou ainda através das grandes greves organizadas pela ADUSP que contavam com a participação dos alunos de graduação e pós-graduação.

A perspectiva adotada pela presente pesquisa de compreender a trajetória de vida

\footnotetext{
${ }^{99}$ MATOS, O. C. F. “A Educação e a Produção de Saberes e Olhares”. In: PRADO, M. L. C. \& VIDAL, D. G. À Margem dos 500 anos: Reflexões Irreverentes. São Paulo: Edusp, 2002.

${ }^{100}$ Ver: SADER, E. Quando novos personagens entram em cena. Rio de Janeiro: Paz e Terra, 1995.
} 
acadêmica dos docentes da FFLCH-USP questiona certas abordagens em relação à participação dos intelectuais no longo processo de redemocratização e refuta análises precipitadas que tratam, ora de uma "Era de participação crítica e em massa dos intelectuais", ora de uma "Era de silenciamento e acomodação". A observação das trajetórias que serão discutidas a seguir permitirá uma avaliação mais ponderada a respeito da participação dos intelectuais bem como do amadurecimento de suas próprias perspectivas na definição e orientação do papel que coube aos intelectuais durante a reconstrução da democracia brasileira.

Dentre as primeiras análises a respeito da participação dos intelectuais no período de democratização brasileira, destaca-se o de Maria Hermínia Tavares de Almeida ${ }^{101}$ que analisou a participação pública de alguns intelectuais entre 1972 e 1984. Sua pesquisa se ateve mais especificamente aos intelectuais que publicaram artigos nos jornais Opinião (1972-1977) e Folha de São Paulo (1978-1984), dentre eles, vários professores pertencentes à Faculdade de Filosofia, Letras e Ciências Humanas da USP foram citados. Segundo a autora, existem razões estruturais que explicam a grande participação dos professores das áreas de humanas na arena política e estes são igualmente responsáveis por criarem usos não acadêmicos para seus trabalhos. Entre as principais razões apontadas estavam a precária institucionalização da vida acadêmica e a inconstância de recursos para pesquisas ${ }^{102}$.

Entre os intelectuais pesquisados por Tavares de Almeida, a professora Marilena Chauí aparece no topo da lista em número de artigos produzidos no período supracitado, com 99 publicações, seguida por vários outros professores da USP: José Álvaro Moisés, Francisco Weffort, Francisco de Oliveira e Maria Victória Benevides. A presença de Marilena Chauí a partir de 1978 em alguns debates sobre a questão da democracia e a respeito do papel dos intelectuais deu origem a textos que foram posteriormente publicados no livro Cultura e Democracia: o discurso competente e outras falas ${ }^{103}$.

Para Daniel Pécaut, pesquisador também atento à atuação dos intelectuais durante o processo de transição política, a nova "era do intelectual como ator político" no Brasil

\footnotetext{
${ }^{101}$ Maria Hermínia T. de Almeida é docente titular aposentada do Departamento de Ciência Política da FFLCH-USP e, coincidentemente, também se enquadra dentro do perfil docente estudado nesta pesquisa. ${ }_{102}$ Para a autora, "nessas condições, a vida política exerce uma atração permanente sobre os profissionais da academia. Além do mais, uma certa exposição pública multiplica os trunfos para uma carreira acadêmica bem sucedida...". Ver: ALMEIDA, M. H. T. de. Tomando partido, formando opinião - cientistas sociais, imprensa e política. São Paulo: Sumaré, 1992, pp.22-26.

${ }^{103}$ Ver capítulos "A questão democrática" e "Democracia e Socialismo: participando do debate" na obra: CHAUÍ, M. S. Cultura e Democracia: o discurso competente e outras falas. São Paulo: Cortez, 1989.
} 
teve início em 1972, quando muitos defenderam o voto nulo e, principalmente, em 1974 quando Fernando Henrique Cardoso, Francisco Weffort, Luiz Werneck Vianna e Maria Hermínia Tavares de Almeida participaram da atualização do programa do MDB a convite de Ulysses Guimarães ${ }^{104}$. Em entrevista concedida para a presente pesquisa, Francisco de Oliveira relembrou a aproximação desses intelectuais em relação à atividade político-partidária:

O Ulysses Guimarães é uma personagem da história brasileira que está a merecer uma biografia e uma avaliação do seu trabalho. Ele dirigiu a oposição brasileira durante alguns dos piores anos da ditadura, sem bravatas e sem recuar um milímetro. Nessa época ele frequentava certos círculos intelectuais, pedia colaboração e atraia gente para a política. Eu não posso me dedicar à tarefa de recuperar a trajetória do Ulisses Guimarães porque isso exigiria muitos anos de pesquisa e entrevistas com aqueles que conviveram com ele e ainda estão vivos. Mas essa é uma necessidade para a democracia brasileira e para a história política brasileira. Durante aquele período de fato havia um monte de gente que atuava proximamente e tinha relações com o então MDB, como o Fernando Henrique Cardoso, o Francisco Weffort, o Luiz Werneck Vianna e a Maria Hermínia Tavares de Almeida. Fernando Henrique inclusive entrou para o partido, nós não entramos. Na campanha de 1974 o Ulisses nos pediu que fizéssemos um programa para a sua candidatura. Não foi o CEBRAP que fez porque não podia executar algo que já era uma atividade partidária. Além disso, a ditadura vivia de olho no nosso trabalho. Então esse grupo de pessoas assumiu essa responsabilidade e fez esse documento que foi entregue ao Ulisses Guimarães. Essa foi a primeira vez em que um partido político sistematizou ideias e proposições para a sociedade brasileira. Era um programa social-democrata e seguia, portanto, as linhas gerais que os partidos socialistas da Europa faziam. Foi um programa muito importante porque a partir daí abriu-se um debate sobre questões brasileiras e institucionais. Foi praticamente $\mathrm{o}$ programa que ficou para o país.

A narrativa de Oliveira acenou para a nova tendência dos intelectuais em dar apoio formal ao processo de institucionalização das lutas de resistência à ditadura que, por sua vez, marcaria também a sua aproximação em relação à agenda democrática. Aos poucos, a mobilização estudantil e dos professores, reconquistavam também os espaços anulados pela ditadura dentro das universidades, retomando suas atividades em torno da luta pelas liberdades civis e políticas.

\footnotetext{
${ }^{104}$ PÉCAUT, D. Os intelectuais e a política no Brasil - entre o povo e a nação. São Paulo: Ática, 1990, p. 300. Maria Kinzo também examinou a aproximação de intelectuais em relação ao MDB. Ver: KINZO, M. D. G. Oposição e autoritarismo - gênese e trajetória do MDB (1966-1979). São Paulo: Vértice, 1988.
} 
Novas ações e formas de mobilização política dos docentes da Universidade de São Paulo foram impulsionadas pelas mortes sob tortura de Alexandre Vannucchi Leme em março de 1973, estudante de geologia da USP, seguida pelas mortes do jornalista e professor da ECA-USP Wladimir Herzog, em 1975, e do operário Manuel Fiel Filho em 1976. As missas de sétimo dia realizadas por Dom Paulo Evaristo Arns em março de 1973 e em 1975 na catedral da Sé em São Paulo, tornaram-se marcos no processo de reorganização das forças de resistência à ditadura. $\mathrm{O}$ fortalecimento do MDB nas eleições de 1974 ofereceu também um novo ímpeto às lutas pela redemocratização.

Estudantes e professores da USP mobilizaram-se em torno de novas agendas políticas como o início das investigações a respeito da atuação das agências de inteligência dentro do campus e dos casos de sequestro, tortura e desaparecimentos executados pelos órgãos de repressão. Quase que concomitantemente foram refundados a ADUSP e o Diretório Central dos Estudantes Livre da USP (DCE-USP), batizado com o nome de Alexandre Vannucchi Leme. Tanto o foco da ADUSP quanto o dos estudantes reunidos em torno do DCE, aspiravam um trabalho de reorganização das forças de resistência e elaboração de bandeiras que reivindicavam a redemocratização do país, a começar pela participação na Campanha pela Anistia ${ }^{105}$.

Durante a longa transição foram engendrados novos modos e possibilidades de participação política entre os intelectuais ${ }^{106}$. A mobilização dos docentes em torno da ADUSP, em 1976, levou à construção eminentemente de pautas políticas e de uma proposta de reformulação do estatuto da universidade. Esta associação investigou os atos do regime militar contra seus professores, publicou uma série de denúncias em 1978 que seriam analisadas pela Assembleia Legislativa do Estado de São Paulo e contribuiu efetivamente para o debate nacional em torno das tarefas da universidade no

\footnotetext{
${ }^{105}$ Ao analisar o período, Marcos Napolitano demonstrou o surgimento de uma nova e emergente cultura política no movimento estudantil: “Assim, falar em 'cultura política emergente' nos obriga a entender a crise da categoria 'revolução', como articuladora das práticas e discursos em proveito da categoria 'democracia'. Não que a maior parte das tendências estudantis não representasse a si mesmas como 'revolucionárias', mas de fato, o sentido prático das lutas de 1977 era a ampliação dos espaços da 'democracia' e não a preparação da 'revolução'. As várias leituras sobre o que significava a 'democracia' e seu papel na 'marcha da história' causavam grandes debates no movimento que a duras penas mantinha a sua unidade tática. Portanto, entre 1968 e 1977, a radicalidade estudantil se concentrava na luta por 'liberdades democráticas', uma palavra-de-ordem que nove anos antes poderia ser acusada de 'liberal' e 'conciliadora"'. Ver: NAPOLITANO, M. Cultura e Poder no Brasil Contemporâneo (1977/1984). Curitiba: Juruá, 2002, p.42-43.

106 Adota-se o conceito de "longa transição" elaborado por Maria Kinzo em: KINZO, M. "A Democratização Brasileira - um balanço do processo político desde a transição". São Paulo em Perspectiva, 15 (4), 2001, pp. 3-12.
} 
Brasil. Eunice Ribeiro Durham, uma das fundadoras da Associação e relatora do Livro Negro da USP, publicado originalmente em 1978, mencionou detalhes sobre o contexto de sua reorganização:

Nesse ínterim, em 1975, no contexto da morte do Vladimir Herzog, houve um movimento dos antigos assistentes para criar uma Associação dos Professores. Conheço razoavelmente bem está história. Muitos professores participaram e, em especial, me lembro de dois professores da Biologia que foram importantes no movimento docente: Prof. Erasmo Garcia Mendes e Domingos Valente. Havia, antes de 1964, uma Associação dos Auxiliares de Ensino, pensou-se em fundar uma associação do mesmo tipo. Afinal, naquele tempo, só tinha o professor titular e o auxiliar de ensino. E os professores da USP começavam como auxiliares de ensino. Em pleno regime militar, obter a legalização de uma instituição como essa, seria muito difícil. Descobrimos, então, que a Associação dos Auxiliares de Ensino não tinha sido formalmente extinta. Então retomamos aquela associação existente de direito, mas não de fato, mudamos o estatuto para os titulares poderem participar também e cobrimos todas as áreas docentes. Realmente, esse movimento supriu a ausência dos estudantes porque o movimento estudantil tinha sido praticamente destruído nessa época. A nova associação contou especialmente com a participação dos docentes mais jovens muitos dos quais, em 1968, tinham atuado ainda como estudantes. Criou-se, assim, um ambiente novamente muito estimulante dentro da universidade. Naquele momento, ao discutirmos a questão da universidade, estávamos convictos de que teríamos que fazer uma reforma. Era um movimento de contestação ao regime, mas não era um movimento qualquer de simples oposição, sabíamos que precisávamos combater os militares com alguma coisa. E esse algo era a reforma universitária. Então para mim foi uma coisa muito boa.

As reuniões organizadas pela Sociedade Brasileira para o Progresso da Ciência (SBPC) em plena ditadura militar demonstravam a determinação dos professores universitários de todo o país em torno da discussão de temas diversos e, inclusive, do papel da ciência e dos intelectuais durante a organização de um novo regime político. Sendo um fórum anual e permanente que viabilizava o desenvolvimento de projetos políticos que contestavam o regime vigente, a ditadura coibiu a realização da $29^{a}$ reunião da SBPC que seria executada inicialmente na Universidade Federal do Ceará, tendo, em seguida, proibido também o transcurso das atividades nas dependências da Universidade de São Paulo na capital ${ }^{107}$. O evento finalmente pode ser concretizado na Pontifícia Universidade Católica de São Paulo (PUC-SP) entre os dias 06 e 13 de julho

107 NADER, H. B. Relatório de Atividades SBPC (2011-2013). Disponível em: http://www.sbpcnet.org.br/site/pagina/relatorio.pdf. Consultado em 26/02/2014. 
de 1977, graças ao empenho de Dom Paulo Evaristo Arns que, assim, desafiava mais uma vez a ditadura ao conceder um espaço vital para a realização do evento ${ }^{108}$.

Em 08 de agosto de 1977, o pronunciamento da Carta aos Brasileiros realizado no pátio das Arcadas na Faculdade de Direito do Largo São Francisco pelo Professor Goffredo Telles Júnior, docente da Faculdade de Direito da USP, no ensejo da retomada das aulas no segundo semestre de 1977, criticava o lema Segurança Nacional e Desenvolvimento, principal bandeira de propaganda do regime autoritário e atualizava princípios básicos do Estado de Direito democrático, destacando a importância da soberania popular. Propunha, assim, uma inversão do projeto ditatorial: segurança e desenvolvimento no interior de um Estado de Direito. Entre as passagens mais marcantes da Carta aos Brasileiros, Telles expunha a distinção entre o legal e o legítimo:

A fonte legítima secundária das leis é o próprio legislador, ou o conjunto dos legisladores de que se compõem os órgãos legislativos do Estado. Mas o legislador e os órgãos legislativos somente são fontes legítimas das leis enquanto forem representantes autorizados da comunidade, vozes oficiais do Povo, que é a fonte primária das leis.

O único outorgante de poderes legislativos é o Povo. Somente o Povo tem competência para escolher seus representantes. Somente os Representantes do Povo são legisladores legítimos ${ }^{109}$.

O empenho dos intelectuais em combater a falta de legitimidade do regime militar e providenciar o restabelecimento do Estado de direito mediante a organização de eleições livres para o legislativo e o executivo, recolocava a questão democrática no cerne de um amplo debate travado por intelectuais filiados a diferentes perspectivas político-ideológicas. Nesse sentido, a retomada da questão democrática reacendeu as divergências entre as concepções defendidas por liberais, socialdemocratas e, as várias tendências de esquerda, redesenhadas em torno dos rumos da longa transição trançada e da construção de projetos políticos futuros.

A democracia como valor universal, ensaio político escrito por Carlos Nelson Coutinho em 1979, semeou um amplo debate entre as esquerdas e as forças oposicionistas pertencentes ao campo liberal. Endereçado aos velhos dirigentes do PCB,

\footnotetext{
${ }^{108}$ A PUC-SP organizou uma importantíssima frente de resistência à ditadura civil-militar e contratou uma série de intelectuais a exemplo de Florestan Fernandes, Octávio Ianni, Bento Prado Jr. e José Arthur Gianotti que tinham sido aposentados compulsoriamente da USP pelo governo ditatorial.

${ }^{109}$ TELLS JÚNIOR, G Carta aos Brasileiros. Ver: http:/www.goffredotellesiradv.br/site/paginaphp?id pg=30\#um. Consultada em 25/02/2014.
} 
inclusive ao grupo liderado por Luiz Carlos Prestes, propunha que a democracia e seus valores não fossem tratados apenas como uma etapa necessária para a conquista do socialismo. Partindo de algumas contribuições de Gramsci e, fundamentalmente, das propostas desenvolvidas por Togliatti, Ingrao e Berlinguer, membros do Partido Comunista Italiano (PCI), Coutinho pretendia abolir as concepções "instrumentais" de democracia que, segundo ele, haviam se incrustado nas fileiras do PCB através da "tradição esclerosada" da Terceira Internacional Comunista. A influência desse ensaio para o acirramento dos debates entre os comunistas foi inestimável. Conceitos tais como os de sociedade civil e hegemonia eram finalmente difundidos amplamente entre as esquerdas brasileiras através de uma formulação política cujo centro passava a ser a questão democrática. Coutinho acusava os comunistas brasileiros, inclusive aqueles responsáveis pelas diretrizes teóricas do PCB nos anos 1950, de defenderem uma posição "economicista" e "golpista" da revolução brasileira. Em contraposição a essa concepção, Coutinho propunha conceber a democracia enquanto um "princípio permanente" e integrado à luta de posições em defesa da instauração do socialismo.

Marilena Chauí estabeleceu na mesma época uma comparação entre a perspectiva democrática defendida pelos partidos reformistas e a concepção "instrumental" de democracia da esquerda comunista brasileira. Segundo ela, em ambos os casos:

Deixava-se de pensar a história como produção da diferença temporal (isto é, trabalho interno que uma sociedade efetua sobre si mesma), e tomava-se a história como diferença dos tempos (presente, passado e futuro) encarregada de unir ou separar democracia e socialismo conforme as circunstâncias ${ }^{110}$.

A autora também não poupou críticas às concepções eurocomunistas, o que, em particular, acentuava o debate em relação ao recém lançado artigo de Carlos Nelson Coutinho. Em seus apontamentos, Marilena Chauí identificou algumas aproximações entre o eurocomunismo e a social-democracia. Segundo ela, os eurocomunistas não eram capazes de introduzir uma crítica ao Estado capitalista enquanto tal e, o que era mais grave segundo suas observações, era o fato de não questionarem sequer a ideia do próprio Estado - preferindo ignorar que a própria natureza do Estado é capitalista.

\footnotetext{
${ }^{110}$ CHAUÍ, M. Cultura e Democracia - o discurso competente e outras falas. São Paulo: Cortez, 2001, p.269.
} 
Dentre os trabalhos de pesquisa que procuravam compreender o processo de transição democrática a partir da perspectiva dos sujeitos históricos que se impuseram na cena brasileira na segunda metade dos anos 1970, destaca-se a obra Quando Novos Personagens entram em cena, de Eder Sader. Este autor investigou a formação das associações de mulheres nas periferias das grandes cidades, o surgimento do novo sindicalismo e suas principais reivindicações, bem como o papel das Comunidades Eclesiais de Base (CEBs). O trabalho de Sader desenhou histórica e socialmente a ascensão desses novos sujeitos sociais como agentes políticos responsáveis pela transformação imediata no seu meio e base fundamental para a organização do Partido dos Trabalhos ${ }^{111}$.

Francisco Weffort desde a publicação de Por que democracia? procurou além de criticar o caráter instrumental de algumas concepções democráticas, pensar o papel da transição e a importância da sociedade civil como "espaço da política" e força indispensável na construção das "novas democracias". Mais tarde, nos anos 1990, Weffort consolidaria as suas análises em torno da questão democrática e avançaria na avaliação do processo de transição ao examinar as continuidades e rupturas no processo de construção das "novas democracias". Partindo dos pressupostos de Bobbio e Dahl quanto às regras mínimas do jogo democrático e a respeito do papel das instituições e lideranças políticas, Weffort passaria a reivindicar também a necessidade de se avaliar como a garantia de condições sociais mínimas daria sustentação real e conteúdo concreto ao postulado formal da democracia ${ }^{112}$.

A (re)introdução da questão democrática possibilitou não só a construção de uma crítica ao stalinismo e ao autoritarismo como atualizou os questionamentos em relação aos limites dos projetos social democráticos, inaugurando um momento sui generis na formação e estruturação de novas perspectivas de pesquisa atreladas ao novo contexto político e social. Como observou Marcos Napolitano, "a democracia passou a ser o pressuposto básico e a matriz simbólica pela qual se enunciavam e se articulavam, politicamente, as lutas sociais. O aprofundamento da democracia se consolidava como um telos histórico compartilhado pelos protagonistas" "113. Contudo, a reorganização das forças políticas de resistência ao regime ditatorial esteve longe de reunir os intelectuais em torno de uma proposta articulada e coesa de democracia. O debate político foi

\footnotetext{
${ }^{111}$ SADER, E. Quando novos personagens entram em cena. Op. cit..

${ }^{112}$ WEFFORT, F. “Novas democracias. Que democracias?”, Lua Nova, nº. 27, São Paulo, Dec. 1992.

${ }^{113}$ NAPOLITANO, M. Cultura e Poder no Brasil Contemporâneo (1977/1984). Op. cit., p.117.
} 
intenso e repleto de contradições, permitindo a estruturação de diferentes concepções de democracia que refletiriam tanto nas opções políticas quanto nas pesquisas e interpretações sobre a sociedade brasileira que seriam adotadas.

Sérgio Buarque de Holanda, Antônio Cândido, Florestan Fernandes, Marilena Chauí, Eder Sader, Francisco Weffort, Francisco de Oliveira, José Álvaro Moisés, entre outros intelectuais, trabalharam na construção do Partido dos Trabalhadores e gestaram importantes contribuições teóricas que acabaram sendo responsáveis pela formação da identidade do nascente partido. O grupo de intelectuais "eurocomunistas", formado por Carlos Nelson Coutinho, Armênio Guedes, Leandro Konder, Luiz Werneck Vianna, Marco Aurélio Nogueira entre outros, mantiveram sua militância em defesa de suas concepções políticas através de seminários, mesas redondas e publicações acadêmicas, além de textos publicados na imprensa em geral. Alguns dos seus membros filiaram-se ao Partido dos Trabalhadores em 1989, outros, descontentes com os rumos do partido participaram ainda da fundação do Partido Socialismo e Liberdade (PSOL) em 2005.

A música da transição política era tocada no tom determinado pela questão democrática. Mesmo no interior das esquerdas intelectuais exercitavam-se novas cadências que, mesmo imbuídas por uma perspectiva que tinha como fundamento a crítica às contribuições advindas do liberalismo clássico, procuravam costurar pressupostos advindos do materialismo histórico com princípios democráticos. Em um contexto no qual as teses liberais de Norberto Bobbio começavam a ditar as regras do jogo da boa convivência democrática e a interferir na agenda política de partidos como o PT e o PMDB, intelectuais como Florestan Fernandes e Décio Saes insistiam em introduzir temas essenciais para as esquerdas. Dentre eles, destacava-se a necessidade de superação das desigualdades sociais para a consolidação da igualdade econômica, a convicção de que a questão da revolução e o domínio do Estado pelas classes trabalhadoras eram essenciais para uma democratização efetiva da sociedade.

Florestan Fernandes desde a publicação de A Revolução Burguesa no Brasil contestava também as leituras "etapistas" da história brasileira propostas pelo PCB, demonstrando as particularidades da revolução burguesa na periferia do sistema capitalista e, particularmente, as características específicas da própria burguesia nacional: essencialmente antidemocrática. Em franco processo de transição trançada, Florestan publicou em 1985 um livro seminal intitulado Nova República? no qual avaliou a proposta de uma "revolução democrática", destoando das análises que 
insistiam em deslocar a democracia de qualquer proximidade em relação às ambições socialistas.

Fernandes discordava veementemente das propostas que apontavam para o processo político em andamento e o denominavam de nova república. Dizia ele: "Ela não é nova e não é uma república". Tratava-se da elaboração de uma crítica a certas concepções formuladas por parte das esquerdas que atribuía à burguesia um caráter revolucionário. Para o autor, a revolução democrática no Brasil não seria burguesa e nem fruto de projetos da social democracia, mas obra daqueles que se opunham ao modelo político e econômico conservador e autoritário das classes dirigentes no país:

De pronto, observa-se que tal revolução democrática não é burguesa. Ela se desenrola dentro de uma sociedade civil, de uma Nação e de um Estado que são burgueses. As classes burguesas, contudo, não se aprestam em levar essa revolução para a frente: buscam, deliberada e reiteradamente, destruí-la, confundi-la, inviabilizá-la, pelos métodos mais refinados e pelos métodos mais brutais a um tempo. É uma revolução que eclode dentro da ordem, mas que se aninha na parte excluída e ignorada dessa mesma ordem ${ }^{114}$.

Na mesma perspectiva crítica aberta por Fernandes, Décio Saes participou diretamente do debate em torno da questão democrática e da cidadania através de artigos e livros que foram publicados desde os anos 1980 até hoje. Partindo de fundamentos teóricos marxistas, Saes contestou as posições de Coutinho referentes à "democracia como valor universal" e explicitou suas posições em artigo intitulado "A democracia burguesa e a luta proletária”, no qual defendeu o que chama de caráter democrático do socialismo:

É o poder político proletário, exercido simultaneamente por duas vias distintas (a do Estado e a das organizações de base), que denominamos, aqui, democracia socialista. (...) No socialismo, democracia não é uma das formas possíveis do Estado e, sim, a própria essência do Estado socialista proletário. Tal expressão indica, aqui, o controle efetivo da burocracia estatal pelos trabalhadores manuais. Mas o termo democracia cobre também, no socialismo, a outra dimensão do poder político dos trabalhadores manuais; vale dizer, o exercício desse poder político pela via não-estatal (organizações de base) $^{115}$.

\footnotetext{
${ }^{114}$ FERNANDES, F. Nova República? Rio de Janeio: Zahar, 1986, p.85.

115 SAES, D. A. M. Democracia. São Paulo: Ática, 1987, p. 81. Ver também: SAES, D. A. M.. "A Democracia Burguesa e a Luta Proletária”. TEORIA \& POLITICA, São Paulo - SP, v. 2, p. 1-2, 1981.
} 
Das considerações em torno da "democracia como valor universal", apresentadas pelo texto inaugural de Coutinho, à "democracia como valor socialista e proletário" na formulação elaborada por Saes, os intelectuais esforçavam-se para manter aberto o horizonte político demonstrando a sua disposição em participar da construção de um projeto de futuro para o país. A longa travessia para a democracia política que se encerrou com a primeira eleição direta para a presidência da república em 1989, mobilizou esforços de toda a sociedade civil em torno da participação efetiva dos cidadãos na vida pública e exigiria uma definição dos próprios intelectuais em relação ao seu papel público.

Por mais limitada que pudesse se apresentar nos planos econômico e social, a democracia política permitiu o engajamento dos intelectuais em diferentes projetos político-ideológicos e abriu caminho para as mais diversas possibilidades de atuação: desde a participação político-partidária, a ocupação de postos nos governos municipal, estadual e federal, o envolvimento e divulgação de trabalhos científicos e atuação na grande imprensa. Pari passo ao processo de transição política, caminhava a profissionalização docente na Universidade de São Paulo, que permitia e incentivava o fortalecimento da atuação no interior da vida acadêmica com a criação de novas linhas de pesquisa, novos cursos de pós-graduação, núcleos de pesquisa, fóruns de debate e congressos que fortaleciam o surgimento de novas áreas de estudo e investigação.

Contrariando os críticos do processo de profissionalização presos à tradição das cátedras, os professores pertencentes à comunidade docente estudada entendiam que os concursos públicos seriam capazes de por um fim no domínio dos catedráticos. Nesse sentido, a luta travada dentro da universidade era parte da recomposição das forças de resistência à ditadura e da reorganização de uma agenda política em torno da democracia. Destarte, as garantias conquistadas com a segurança proporcionada pela carreira pública permitiram que os docentes pudessem assumir livremente suas escolhas políticas.

Os anos 1980 inauguraram um período no qual a comunidade docente passou a estar comprimida entre as mudanças profissionais iniciadas na década anterior e as cobranças no sentido de ter que atender às novas demandas impostas pela sociedade e pelo Estado. Espremidos entre contextos diferentes, os docentes passaram a ser convidados a definir e a desempenhar novos papéis sociais e profissionais, que viriam a fortalecer a produção acadêmica e reinventar o espaço de autonomia e liberdade. Como 
durante a ditadura o espaço público de atuação, muitas vezes, se restringia à universidade e grupos de pesquisa, com o processo de redemocratização ele passou a ganhar novas proporções e, rapidamente, a sociedade começou a questionar o papel dos intelectuais, da universidade pública e, em especial, das humanidades. Afinal, como a comunidade docente lidou com as novas cobranças e responsabilidades acarretadas pela institucionalização da carreira acadêmica e formulou respostas às novas demandas democráticas?

A democratização política, enfim, acirrou as divergências e conflitos internos na Faculdade de Filosofia Letras e Ciências Humanas da USP. O combate às cátedras e a resistência à ditadura mobilizava a maior parte dos docentes em torno da causa democrática, mas bastou a democracia política se firmar para que as dissensões viessem à tona. $\mathrm{O}$ dissenso democrático alimentou novas possibilidades e exigiu esforços na produção de reflexões capazes de interrogar de forma pertinente as mudanças e os limites das reformas em curso no país. A questão da participação, do papel e das responsabilidades do intelectual ganhou novos contornos após a ditadura e promoveu a abertura de um diálogo entre os docentes e os recentes partidos políticos em atuação, bem como consagrou uma nova relação com as esferas de poder local, estadual e federal.

As entrevistas de história oral de vida acadêmica possibilitaram a abordagem de temas políticos vinculados às trajetórias intelectuais. Dentre aqueles sugeridos pelo entrevistador que mais sobressaíram nas conversas travadas com os docentes, estão o do papel do intelectual no mundo contemporâneo e suas relações com o mundo da política; a questão do trabalho acadêmico e de sua responsabilidade pública, bem como a necessidade de avaliar a produção intelectual e os problemas impostos pelo produtivismo que veio à tona com a publicação em fevereiro de 1988 da chamada "Lista dos improdutivos". E, finalmente, destacaram-se as posições dos docentes em torno da divisão da FFLCH-USP, questão debatida amplamente no início dos anos 2000 e recentemente retomada em 2012 por alguns docentes.

O presente capítulo está dividido, portanto, em três partes. O primeiro ponto a ser discutido tratará da preocupação dos docentes em relação à autonomia do intelectual frente às questões de ordem política. Analisar-se-á os motivos que levam tanto aqueles que desenvolveram uma atuação político partidária, quanto os que sempre foram 
contrários à atuação político partidária, citarem e defenderem a autonomia intelectual como condição sine qua non para o desempenho de um papel crítico e independente.

$\mathrm{O}$ segundo tema a ser abordado diz respeito às transformações ocorridas na política acadêmica e científica e o modo como os membros da comunidade docente em transição atuaram, ora no papel de articuladores e gestores da burocracia, ora na condição de resistência e crítica aos modelos avaliativos adotados. Apresentar-se-á as preocupações dos docentes a partir da concretização definitiva da profissionalização da carreira docente e do avanço da instrumentalização da política universitária - quando uma nova natureza de gestão administrativa passou a coordenar a quantidade dos recursos liberados para pesquisas de acordo com o retorno previsto em produção acadêmica, ou seja, quando uma espécie peculiar de accountability tornou-se peça central no planejamento e fomento das políticas educacionais.

O terceiro e último tópico a ser tratado apresentará os desacordos em torno da unidade e divisão da FFLCH-USP. Essa questão traz em seu âmago, na verdade, a concepção dos docentes a respeito do papel da FFLCH-USP, a questão da interdisciplinaridade e do debate acadêmico e, por fim, as dificuldades de administração de sua complexa e ampla estrutura pessoal e infraestrutural.

\subsubsection{Docência e atuação política.}

A democracia política produziu dissenso e, por sua vez, este permitiu a construção e o aprofundamento do espaço público. Os debates em torno da questão democrática travados entre os intelectuais avançaram também no sentido de favorecer a intensificação de um diálogo cada vez mais profícuo entre a academia e a sociedade. Comprimida entre dois contextos políticos diversos, a comunidade docente em trânsito passou a ser requisitada por diferentes grupos sociais, políticos, empresariais e, pelo próprio Estado, a desempenhar novos papéis. Isso implicou uma carga de novos desafios em torno da vida acadêmica: como conciliar uma carreira cada vez mais exigente, burocratizada e repleta de responsabilidades administrativas, educacionais e de pesquisa com a oferta das mais diversas demandas externas? Qual seria o papel da 
universidade pública e do intelectual que nela trabalha para a comunidade docente pertencente à Faculdade de Filosofia?

A redemocratização atingiu fortemente o trabalho acadêmico ao apresentar possibilidades amplas de participação dos intelectuais na vida pública. Além disso, a democracia política embaralhou as certezas que existiam durante o consenso imposto pela ditadura, o que levou as forças progressistas a providenciarem a reorganização de seus espaços de atuação.

As histórias de vida acadêmica, bem como a análise dos memoriais de "titulatura" pesquisados, possibilitaram explorar e problematizar como as preferências teóricas e as atividades acadêmicas desenvolvidas pelos docentes dialogaram ao longo do tempo, muitas vezes, através da atuação na política acadêmica, ou, simplesmente, desenvolvendo pesquisas e apresentando posicionamentos críticos diante de problemas relativos à sociedade ou, ainda, desempenhando atividades político-partidárias. A participação dos intelectuais no debate em torno das perspectivas democráticas e a possibilidade de uma participação mais efetiva trazia em sua essência uma nova questão: qual seria o papel desempenhado pelos intelectuais em uma democracia política? Haveria um padrão de comportamento ideal defendido pelos docentes para os intelectuais?

Em se tratando de professores titulares, todos vivenciaram amplamente as várias etapas burocráticas e teórico-intelectuais da atividade acadêmica. No entanto, é preciso reconhecer a existência de ênfases diferentes que marcaram cada história profissional individualmente. Em algumas carreiras identificou-se uma maior propensão e afinidade com questões próprias ao meio acadêmico stricto senso e suas variantes políticas internas, outras, foram marcadas mais determinantemente por atuações para além dos muros da universidade com finalidades políticas explícitas. Em ambos os casos foi necessário observar as diferentes dimensões do político e suas implicações na construção do trabalho e da carreira docente.

Algumas trajetórias acadêmicas possuem relações mais enfáticas com temáticas públicas e, até mesmo, com a participação efetiva dos professores seja na política partidária, seja ocupando cargos no governo. Em outras, percebe-se uma tendência mais fortemente voltada para a produção científica e para o estabelecimento de outras maneiras de dialogar com a sociedade. O objetivo desse capítulo é justamente o de colocar à prova tais tentativas de catalogação, problematizando o conjunto de trajetórias 
de vida acadêmica pesquisadas, procurando compreender a relação que os docentes possuem em relação à universidade pública, com o Estado e com o mundo político partidário.

Via de regra, as atividades acadêmicas desempenhadas pelos docentes em questão foram e continuam sendo avaliadas pelos seus próprios pares e pelas agências de financiamento. Portanto, a pesquisa jamais pretendeu questionar a produção acadêmica desses docentes seja em relação a sua periodicidade ou quantidade, trabalho este já realizado pelas agências competentes. A presente investigação esteve preocupada em avaliar e compreender a relação estabelecida por esses professores em relação à comunidade e como mediaram a relação entre universidade pública e espaço público. Diante desse fato, as entrevistas permitiram acompanhar as principais inquietações desses docentes em relação às próprias carreiras e, a partir daí, foi possível apreender algumas considerações a respeito do papel dos intelectuais circunscritas a alguns problemas, a saber:

1) O significado e a importância da questão da autonomia intelectual;

2) A relação dos docentes com o Estado e com cargos nas esferas de governo;

3) A participação em partidos políticos.

Em muitas entrevistas a questão da autonomia intelectual seguramente foi o tom vital imprimido pelos docentes na reorganização das trajetórias apresentadas em forma de narrativa. Alguns professores foram enfáticos em ressaltar que nunca admitiram qualquer ingerência externa sobre o seu trabalho de criação intelectual, fosse na universidade ou fora dela. A condição de funcionário público de carreira permitiu a construção de uma autonomia intelectual responsável pela livre definição de suas trajetórias. Essa nova função interferiu diretamente na forma como esses intelectuais se relacionaram com o Estado, com as diversas esferas de governo, os partidos políticos e a própria vida acadêmica. Como uma das hipóteses dessa pesquisa, acredita-se que a estabilidade propiciada pela carreira consolidada entre o final dos anos 1970 e início dos 1980, foi responsável pela estruturação de um novo perfil docente caracterizado por uma sólida e consistente independência profissional.

Uma análise que queira vasculhar as relações existentes entre o trabalho científico e as questões políticas não pode aceitar um sistema de interpretação fechado. Deve-se 
atentar para as imbricações particulares, caso a caso, entre as perspectivas teóricas e políticas envolvidas. Faz-se necessário ampliar, portanto, a noção de engajamento e de atuação política, afinal, a figura do docente é indissociável da do cidadão, como advertiu Florestan Fernandes.

\subsubsection{Trajetórias individuais de uma coletividade em transição.}

As entrevistas realizadas permitiram compreender nuances particulares de cada trajetória, bem como possibilitaram uma visualização do conjunto das várias experiências acadêmicas vividas pelos docentes. Fez-se necessário, portanto, distinguir em meio às marcas gerais de uma coletividade o que cada carreira acadêmica possui de específico para, em seguida, proceder à reconstrução do todo, retomando dialeticamente as características gerais da comunidade estudada. Um exame mais detido de algumas trajetórias evidenciou que houve casos em que as próprias carreiras individuais apresentaram oscilações, ou seja, ora o intelectual desempenhou uma atividade mais próxima da esfera político partidária, ora ele se afastou dos holofotes públicos e concentrou suas energias no dia a dia acadêmico. Existem ainda os casos que podem ser considerados limites, aqueles formados por docentes que nunca se envolveram diretamente em atividades políticas e permaneceram contrários à ideia de um intelectual se filiar formalmente a um partido político e, outros, nos quais o professor defendeu a plena participação política dos professores na vida político-partidária.

$\mathrm{Na}$ verdade, muitos dos docentes entrevistados fizeram política desde a escola secundária e durante a graduação, tendo iniciado sua militância na igreja, no movimento estudantil ou em partidos políticos. As oportunidades surgidas nas décadas de 1960 e 1970 se somaram a uma postura prévia que seria enriquecida por uma acuidade e um refinamento político e teórico que se consolidaria na prática política efetiva.

A história de vida acadêmica de Abdala Jr. expõe as dificuldades de se rotular as trajetórias intelectuais pertencentes à comunidade acadêmica estudada. Nos anos em que cursou Letras na Maria Antônia atuou no movimento estudantil tendo sido secretário geral do grêmio da Faculdade de Filosofia onde dirigiu um jornal estudantil intitulado Amanhã. Publicado semanalmente com uma tiragem de 20 mil exemplares, 
sofreu retaliação e censura dos órgãos de repressão e teve suas atividades encerradas. Mais tarde, como professor da rede estadual de ensino, desempenhou um papel de liderança em uma greve ocorrida em 1967. Preso entre os anos 1969 e 1971, acusado de participar de atividades políticas clandestinas, contou com o apoio de sua orientadora e de outros professores da USP para iniciar os preparativos para a pós-graduação quando encarcerado no Presídio Tiradentes. A partir do seu retorno à universidade, iniciou uma longa carreira acadêmica da qual nunca mais se desvencilharia.

Em um momento marcante da sua narrativa, Benjamin Abdala distingue a participação política que empreendeu durante a ditadura dos momentos posteriores vivenciados no contexto da redemocratização política:

Eu tive ligações com partidos políticos na época da ditadura até quando me prenderam. Não estava afastado, mas já estava meio distante. Depois, quando saí do Presídio Tiradentes, fui convidado para entrar no Movimento Democrático Brasileiro (MDB), depois no Partido da Social Democracia Brasileira (PSDB), no Partido dos Trabalhadores (PT) e no Partido Comunista do Brasil (PC do B). Fui convidado para entrar nessas organizações, mas eu não quis entrar. Contudo, sempre tive participação política. Agora, por exemplo, estou apoiando o Haddad. Ajudei na feitura do plano de governo dele e tenho feito algumas coisas a favor do Haddad. Então eu nunca deixei de fazer política, mas não no sentido partidário, ligado a partido e tal. Eu não faço parte do PT, então isso me dá certa liberdade. Quer dizer, eu não estou desconsiderando os partidos, considero-os necessários, mas pessoalmente acabei optando por ficar mais livre, sem deixar de apoiá-los no que me parecer justo.

Destaca-se na exposição de Abdala Jr. a maneira como passou a lidar com os partidos políticos após a ditadura militar. Ao elaborar uma interpretação sobre a sua participação política durante o processo de redemocratização, manifestou preocupação em desempenhar enquanto intelectual uma atividade independente e autônoma. Ao tratar de questões mais recentes e ao afirmar que apoiou o candidato Fernando Haddad à prefeitura de São Paulo, tendo trabalhado na elaboração de seu plano de governo, Benjamin Abdala acrescentou em seu comentário uma ressalva não menos contundente: "Eu não faço parte do PT, então isso me dá certa liberdade". Pode-se inferir que ao reafirmar seu papel enquanto intelectual, Benjamin fez a opção de desempenhar uma atuação política dentro de certos limites e sem jamais perder de vista a sua condição de crítico independente. Nesse sentido, a sua situação profissional parece conferir não somente autoridade, como também funcionar tal qual uma barreira de proteção, devendo 
ficar claro ao partido que a sua posição é a de um colaborador que detém autoridade docente e, principalmente, total autonomia.

Faz-se necessário observar que o tipo de atuação desempenhada por Abdala Jr. foi certamente fruto de um contexto histórico específico. O vínculo à universidade pública lhe angariou não somente a autoridade necessária, mas também propiciou as condições indispensáveis para o desenvolvimento de sua plena autonomia, tanto a econômica, quanto àquela reivindicada por todos os docentes entrevistados, a capacidade de pensar e elaborar análises autônomas. Ambas as conquistas somente se tornaram possíveis a docentes como o Benjamin Abdala, graças à segurança proporcionada pela carreira acadêmica pública e pelo regime de dedicação exclusiva que foi estendido a partir do final dos anos 1980 à grande maioria dos professores da FFLCH-USP:

Quando fui convidado para entrar no PT, queriam que eu fosse candidato a deputado. Mas eu tinha acabado de ingressar na USP como professor. Naquela época, não havia ainda dedicação exclusiva, também chamada de tempo integral, essa foi uma conquista posterior. Entrei na USP em regime de tempo parcial e, assim, tinha que dar aulas em faculdades particulares e tinha muitos alunos. Em uma dessas faculdades eu dava aula para cerca de 800 alunos de várias classes, cada uma tinha 120 alunos. Como eu estava diante de um grande público, acharam que eu tinha que ser candidato a deputado. Aliás, foram uns alunos mesmo que vieram falar comigo e que queriam minha candidatura a deputado pelo PT. Mas eu não quis. Além disso, eu também tinha muitos amigos que estavam no MDB e queriam também que eu participasse das coisas. Eu ficava em torno dos partidos, sem deixar de apoiá-los, mas nunca assumi.

A decisão de manter-se desvinculado de partidos políticos e atuar junto a eles não oficialmente, estava ligada às novas oportunidades inauguradas pelo contexto de redemocratização. A reconstrução do espaço público inaugurava novas possibilidades de atuação política para além das formalidades partidárias e dos cargos oficiais. Assim, os intelectuais que tinham interesse em uma participação política mais efetiva podiam se aproximar dos partidos políticos em formação e dos governos por eles administrados, sem participar diretamente das atividades político-partidárias. Nascia a figura pública do intelectual que procura participar da vida política, mas não pretende estar preso a vínculos partidários argumentando que, somente nessas condições, pode garantir sua autonomia crítica. 
Há também uma forte propensão por parte de outros membros da comunidade docente estudada em defender uma posição intelectual autônoma e independente das questões político-partidárias. Durante a entrevista, Janine Ribeiro foi ainda mais enfático que Benjamin Abdala em relação ao papel do intelectual e de qual deve ser idealmente a sua relação com a política partidária:

Considero incompatível ser intelectual e se filiar a um partido - salvo casos excepcionais, como numa guerra. Porque o fundamental no intelectual é a autonomia, o pensamento crítico. Como criticar, se você é o que Gramsci chamava de intelectual orgânico? O que quer dizer "assumir a perspectiva da classe trabalhadora"? Não existe uma única perspectiva, mas esse mantra convenceu muita gente. Ou o que significa "assumir a perspectiva da classe dominante"? Sempre valorizei a independência intelectual. Claro, alguém pode se achar independente e na verdade estar dominado por preconceitos de qualquer ordem, mas é preciso se esforçar o tempo todo para se auto examinar. Isso é como a imparcialidade, que é impossível - só que, se um juiz ou jornalista não acreditar na imparcialidade, não pode ser juiz ou jornalista.

Como professor de Ética e Filosofia Política na FFLCH-USP, Janine Ribeiro publicou ao longo das últimas duas décadas trabalhos preocupados com a questão da república e da democracia e, em particular, a respeito dos percalços vividos pela democracia brasileira. Defensor da imparcialidade intelectual diante da atividade político-partidária, mas atento à conjuntura política do país, manteve um diálogo público com lideranças pertencentes a diferentes partidos.

Em um artigo intitulado "Perspectivas para o Brasil", publicado em 2002, Janine Ribeiro tratou do que chamou de "democracia petista" e do "republicanismo tucano", apresentando as principais diferenças e, principalmente, uma perspectiva inovadora na qual procurou delimitar a importância de uma aproximação entre o PT e o PSDB, dado o fato de, segundo sua análise, apresentarem características políticas complementares. Ao ter sugerido que o país perdeu uma grande oportunidade política que seria uma união/aliança entre PSDB e PT, Janine Ribeiro foi contemplado com uma resposta elaborada por José Dirceu, tendo início um debate público.

Crítico à posição de Janine Ribeiro, José Dirceu condenou sua avaliação em relação ao PSDB, afirmando que o professor guardava falsas ilusões em relação a seus projetos para o país. Dando prosseguimento a seus argumentos, Dirceu afirmou: 
Não posso deixar de reparar, por fim, nas ilusões do mestre com o papel que poderia cumprir o PSDB. Transformados em partido da modernização conservadora, os tucanos assumiram o lugar da velha direita como articuladores das elites. No rastro das políticas privatistas e antinacionais, foram abandonando compromissos com a radicalidade democrática ${ }^{116}$.

Em sua réplica "Resposta a José Dirceu”, Janine Ribeiro admitiu publicamente ter votado seguidas vezes no PT, enfatizando os avanços sociais conquistados pelo partido no poder, contudo, questionou o partido quanto aos limites ainda existentes no plano político: "Os beneficiados pelas políticas sociais teriam se tornado sujeitos das decisões políticas?". E complementou, indagando: "É este o cerne do meu artigo e de sua proposta talvez insana: não sendo político, tenho o direito de sugerir o inviável; sendo intelectual, tenho o dever de tratar mesmo do impossível" ${ }^{\text {"117. }}$.

Sem estar filiado a qualquer um dos partidos políticos em questão ou a qualquer outro, Janine Ribeiro atuou diretamente dialogando com os partidos políticos e suas lideranças, tanto quanto alguns intelectuais vinculados às legendas. A posição adotada pelo Prof. Renato Janine Ribeiro indica que a questão do envolvimento dos intelectuais com a questão político-partidária não deve ser buscada no nível de seu comprometimento, mas desloca-se, idealmente, da relação estabelecida entre o grau de proximidade para uma posição de distanciamento permanente concedida pela condição particular desfrutada como intelectual. Afinal, para Janine, esta posição é capaz de garantir a liberdade necessária para a elaboração de avaliações críticas e a gestação de alternativas reais. Vale lembrar, mais uma vez, que a profissionalização da carreira e as condições oferecidas pelas universidades públicas contribuíram em grande parte para que os docentes pudessem exercer com segurança seu papel intelectual e, inclusive, tendo lhes garantido autonomia econômica. A sua posição profissional passou a permitir que os docentes pudessem escolher as oportunidades que melhor lhes conviessem ou, simplesmente, continuar atuando como conselheiros distantes.

Dentre os docentes que destacaram a importância dos intelectuais se manterem enquanto livres pensadores, merece atenção o posicionamento de Olgária Matos, colega de Janine Ribeiro no Departamento de Filosofia:

116 DIRCEU, J. “Acordos e Desacordos". Interesse Nacional, Ano 3, 10, jul-set. 2010. Ver: http://interessenacional.uol.com.br/index.php/edicoes-revista/criticas-e-comentarios-2/. Consultado em 02/04/2014.

${ }^{117}$ JANINE, R. "Resposta a José Dirceu”. Idem. 
Durante os Anos de Chumbo estava próxima a vários grupos de resistência, mas nunca fui uma militante orgânica. Eu era muito indisciplinada para estar em um partido. Não suporto partido. Não suporto o conceito de "sociedades", tais como A Sociedade Benjaminiana, a Sociedade da Escola de Frankfurt, a Cartesiana, eu não aguento isso! Participo de todas ativamente, mas a ideia de ter uma identidade única que se define pelo pertencimento em relação a alguma coisa, não é o meu temperamento. Hoje, os intelectuais são a retaguarda atrasada da classe média. Uma classe média pobre de repertório e cujo único valor é o dinheiro, símbolo do novo rico.

Ao defender uma posição autônoma diante das instituições, Matos argumentou que a opção por uma postura indisciplinada favorece uma determinada atitude intelectual autônoma. Ao descrever sua resistência em tornar-se uma militante orgânica, reivindica para si uma forma particular de militância, ligada à própria prática docente e às questões críticas discutidas através do trabalho acadêmico. Nesse sentido, a academia possibilita, para Matos, uma atuação protegida dos processos de racionalização e instrumentalização da atividade intelectual, favorecendo o desempenho de um papel independente e diferenciado.

Mário González também destacou o fato de ter se mantido na posição de um intelectual que não se sentia confortável com a filiação partidária porque "queria se sentir livre":

Devo dizer que simpatizei desde a criação com o PT e acho que no grupo em que trabalhei a simpatia pelo PT era plena. Claro que havia também um grupo que tinha suas restrições e que nunca confiou muito no PT, mas pessoalmente sempre tive muita simpatia e estive em comícios do partido. Acredito que nos anos 1980 e 1990 as principais pautas nacionais eram dadas pelas propostas do PT. Nunca me filiei ao PT porque queria me sentir livre. Não queria me sentir filiado a nenhum partido, nem fiz propaganda do PT, mas minha simpatia com esse partido sempre foi grande. A decepção também foi muito grande, muito grande. Vou dizer o porquê. Acho que no momento em que o Lula disse que para chegar ao poder era preciso fazer alianças com qualquer um, aí acabou. Eu registrei essa frase quando ele ainda era candidato e para mim acabou. E de fato ele assinou embaixo de qualquer coisa e assumiu o poder com as alianças que nós conhecemos e que continuam até hoje.

A justificativa de González está pautada pela necessidade de conservar sua condição de intelectual autônomo, a qual the permite a elaboração de formulações 
críticas a quem quer que seja, inclusive, em relação ao partido que apoiava não oficialmente.

Para Leopoldo e Silva, a prática política pode perfeitamente ser desenvolvida independentemente de vínculos partidários. Ao relembrar momentos de sua atuação no movimento estudantil ligada ao Centro Acadêmico da Filosofia, afirma nunca ter se envolvido diretamente com legendas partidárias:

\begin{abstract}
Sempre tive essa postura de me manter à parte. Isso causava muito estranhamento porque atuei três anos no Centro Acadêmico sem pertencer a nenhum partido. Isso era muito estranho para as pessoas, como elas não sabiam de onde eu vinha, ficava a dúvida do que iria fazer. Como não havia um programa nítido, nunca ocupei posições importantes como a de presidente. No entanto as pessoas que eram muito engajadas e me conheciam, me chamavam para colaborar independentemente de não pertencer ao partido deles. Essa era uma responsabilidade que eu assumia com todos. Mas nunca cedi a convites a vida inteira, até hoje. Nunca me inscrevi em nenhum partido.
\end{abstract}

Para alguns entrevistados, exercer o papel de livre pensador implicava em manter distanciamento seguro em relação à participação partidária. Cultivar a desconfiança em relação às instituições políticas possibilitava a construção de uma posição independente que, além disso, conferia ao docente o distanciamento e a autoridade que são bem vindos aos intelectuais. Algumas entrevistas demonstraram, no entanto, que houve casos em que os docentes, mesmo tendo desempenhado atividades político-administrativas na esfera governamental e em cargos comissionados, preferiram manter-se alijados das questões político-partidárias, problematizando ainda mais as relações entre os intelectuais e a política.

As relações entre a prática intelectual e a atividade política foram interpretadas de diferentes maneiras pelos colaboradores. Mas, em nenhum caso, os docentes dissolveram a atividade intelectual na prática política ou vice versa. Em conversas travadas com professores pertencentes à comunidade docente estudada que desempenharam atividades administrativas e de pesquisa fora da esfera universitária e, algumas vezes, estabelecidas por intermédio de vínculos partidários, observou-se uma significativa preocupação em qualificar e distinguir a ocupação exercida enquanto uma atuação apropriada à condição intelectual. 
Eunice Durham, mesmo tendo desempenhado atividades político-administrativas, enfatizou em sua narrativa que o intelectual tem responsabilidades técnicas e defendeu que o bom desempenho desse papel foi vital para o seu trabalho. A trajetória acadêmica reelaborada no tempo presente por sua memória respeita uma sequência ditada pela produção acadêmica realizada ao longo da carreira a respeito do ensino superior. Segundo a professora, foi o reconhecimento desse cabedal intelectual que lhe proporcionou a oportunidade de trabalhar dentro da esfera do poder. Durham, dessa maneira, costurou em sua narrativa a larga experiência adquirida no governo federal como presidente da Coordenação de Aperfeiçoamento de Pessoal de Nível Superior (CAPES), na Secretaria Nacional de Educação Superior do Ministério da Educação (MEC), na Secretária Nacional de Política Educacional do MEC e como membro do Conselho Nacional de Educação (CNE), vinculando-a a sua trajetória como pesquisadora do ensino superior na Universidade de São Paulo e também como uma das fundadoras do Núcleo de Pesquisas sobre Ensino Superior (NUPES-USP), atual Núcleo de Pesquisas em Políticas Públicas (NUPPs-USP).

Em várias passagens da entrevista, Durham enfatizou que a docência e a pesquisa na universidade sempre foram sua principal atividade, porto seguro para o qual retornava nos momentos de desentendimento vividos na esfera do poder. As afirmações de que "nunca ocupou um cargo político" e de que "sempre foi uma secretária técnica", procuraram demarcar uma posição independente de sua atividade intelectual enquanto funcionária do governo federal e desvincular o trabalho realizado de qualquer ligação com práticas político-partidárias ${ }^{118}$. Sua narrativa revela o desejo de ter a sua trajetória compreendida como a de uma intelectual sem amarras políticas e cujas decisões foram pautadas em dados concretos, científicos, indispensáveis para a elaboração de uma prática autônoma e capaz de atender os interesses da sociedade:

Eu nunca passei completamente do campo intelectual para outro. Nunca tive um cargo político. As únicas eleições pelas quais concorri foram dentro da USP. Nunca tive a vontade de ir para o congresso ou de me candidatar à governadora. Nada disso. Fui sempre uma secretária técnica. Ou, então, uma assessora. Faço muita coisa no campo da assessoria: quando me dão um problema eu analiso, vejo as possibilidades cabíveis e a pessoa depois faz o que quiser com minhas

\footnotetext{
${ }^{118}$ Em julho de 2001 Durham pediu demissão do Conselho Nacional de Educação por considerar que o mesmo perdia poderes para o Ministério da Educação em relação à avaliação e fechamento de cursos superiores, após a publicação de alguns decretos.
} 
observações. Eu não preciso fazer nenhuma negociação política. É uma função importante, mas, de acordo com o meu temperamento, não me vejo lá lutando com os deputados para passar uma legislação. Isso o Paulo Renato fazia bem e o Goldemberg também. A questão é que ficou muito em moda a ideia de que o conhecimento é poder. Quando estava lá no ministério toda hora a esquerda repetia isso de que "o conhecimento era poder". Isso porque eles eram contra qualquer forma de poder. Era uma posição complicada. Acabei descobrindo outra coisa, que o poder é um excelente lugar de conhecimento. Quando se está lá no ministério é possível ver o sistema no seu conjunto, não dá pra você não olhar, porque todo ele vai pedir dinheiro para você. E é preciso pensar onde é que os recursos serão distribuídos, quais são as universidades federais, quantas são as escolas técnicas e a questão das privadas. Tem que haver uma política para cada uma delas.

O esforço de Eunice Durham ao desprender as atividades desempenhadas por ela no governo de práticas político-partidárias - afirmando-se enquanto intelectual autônoma -, é muito representativa. Ao argumentar que seu espaço original e de trabalho sempre foi a universidade, para a qual ela voltava sempre que havia algum problema nos cargos ocupados provisoriamente, a professora sugeriu que sua permanência no governo dependia dos projetos e políticas de Estado serem compatíveis com suas posições político-teóricas. Ao seu modo, Durham procurou defender a autonomia intelectual e sua independência em relação ao Estado e ao grupo político partidário que se encontrava no poder. Em uma leitura feita a contrapelo, seria possível afirmar que sua atuação e permanência no governo dependiam da afinidade entre as suas posições e aquelas defendidas pelos seus superiores. Por mais de uma vez, Durham abandonou suas atribuições na esfera governamental e retornou para a USP por discordar de medidas tomadas no campo educacional. Sendo assim, a carreira acadêmica sempre significou um porto seguro ao passo que, a universidade pública, em especial a FFLCH-USP, era reconhecida como a casa que permitia ao docente desempenhar livremente o trabalho intelectual ${ }^{119}$.

No âmbito da comunidade docente pesquisada, fez-se necessário ainda conhecer a posição dos docentes que desenvolveram ao longo de suas trajetórias atividades vinculadas diretamente a grupos políticos e ou partidários e consideram essa uma prática absolutamente natural ao atribuírem a existência de vínculos entre as atividades

\footnotetext{
${ }^{119}$ Eunice Durham em carta enviada ao então ministro Paulo Renato Souza pediu seu afastamento do Conselho Nacional de Educação por discordar de algumas decisões tomadas em relação ao ensino superior no Brasil em julho de 2001.
} 
acadêmicas empreendidas e suas preocupações enquanto cidadãos. Essas experiências apresentaram características singulares por combinarem práticas eminentemente político-administrativas a assessorias de cunho científico. Durante algumas entrevistas, os professores atribuíram às experiências político-partidárias e ou na administração pública como relevantes e imprescindíveis para a sua formação enquanto intelectuais. Uma vez imbricadas, coube observar como os próprios intelectuais avaliaram as relações existentes entre as partes para que se possa estabelecer uma comparação entre estas e o conjunto das experiências analisadas.

Dentre os docentes que considerou oportuna e salutar a atividade partidária, destaca-se Albuquerque que falou sobre sua participação política e sua experiência na administração pública com a naturalidade de quem atuou politicamente desde a juventude:

Outra coisa que contribuiu, paralelamente à academia, para a minha formação, foi que, com a eleição e a consolidação da grande vitória do PMDB em 1982, fui para a cidade de Osasco trabalhar como secretário municipal em 1983. Primeiro fui Secretário de Promoção Social, responsável pelas creches e centros de convivência para crianças e pelas favelas, ou seja, a parte mais vulnerável da sociedade. Depois, trabalhei como secretário de governo, ao todo por três anos. Em seguida fui para a Secretaria de Planejamento do Estado, fui ser chefe de gabinete do José Serra. Eu levei uma boa parte da experiência que tive lá em Osasco para a Secretaria de Planejamento, e organizou programas semelhantes para desempregados e favelados em toda a Grande São Paulo. Era uma época de altíssimo desemprego, de inflação alta e muita fome. Isso foi uma coisa que marcou minha trajetória intelectual e política. Aprendi que, em certas circunstâncias que praticamente estão presentes em todas as sociedades, inclusive as mais ricas - é plenamente justificável, e na verdade indispensável, adotar políticas "puramente" assistenciais.

É importante notar que Albuquerque apresentou suas atividades políticas como sendo parte intimamente ligada à sua carreira intelectual. No seu entendimento, a sua "formação política propriamente dita", a "real", não poderia ser realizada exclusivamente dentro da academia. Nesse sentido, ao agregar o aprendizado acadêmico aquele pertencente ao mundo da política, revelou implicações subjetivas ao adotar um determinado "método de ação, um conjunto de atitudes e certos valores":

$\mathrm{Eu}$ trabalhei muito também em campanhas eleitorais, como já assinalei. Participei de duas campanhas do Fernando Henrique, a 
primeira para Senador, quando ele concorreu em sublegenda com Franco Montoro em 1978. Mais tarde, em sua campanha para Prefeito, quando ele perdeu para o Jânio em 1985. Nessa campanha, assessorei o governador Montoro já que, em minha posição no Planejamento, eu podia propiciar que ele estivesse presente em ações de governo na Capital, sem se envolver diretamente na campanha.

Bem mais tarde, em 1995, fui ser assessor do Serra no Ministério do Planejamento por um tempo muito pequeno porque, logo em seguida, ele veio concorrer à Prefeitura de São Paulo. Então eu tenho sido parte desse grupo do PMDB e do PSDB, ligado ao Montoro, ao Fernando Henrique e ao Serra. Isso como parte da minha formação política propriamente dita, não a acadêmica, mas a real. Entender isso é importante porque implica a opção por um método de ação, um conjunto de atitudes e certos valores. Em matéria de atuação partidária me filiei apenas ao PMDB quando ele foi criado e, depois, ao PSDB do qual nunca me desvinculei. Antes eu havia criado um partido estudantil, mas nunca fui filiado nem ao PC, nem à Ação Popular, nem a outro partido.

Moisés também desempenhou uma intensa participação política desde a juventude, tendo atuado como presidente da União Paulista dos Estudantes Secundaristas (UPES), membro da Ação Popular (AP) e, mais tarde, um dos fundadores do Partido dos Trabalhadores (PT):

Nesse período nós estávamos fazendo pesquisa desses movimentos sociais e hoje posso afirmar que era muito difícil saber qual era a linha que separava a atividade propriamente de pesquisa e a atividade de solidariedade ao movimento. Isso nos levou a estar na origem de algum desses movimentos. Quer dizer, o Weffort, eu, Chico de Oliveira, o Paulo Singer e o Vinícius Caldeira Brant - que era do CEBRAP e tinha sido presidente da UNE em um momento importante -, todos nós estávamos muito ligados à liderança do Lula que em São Bernardo estava propondo a criação do PT.

Em 1979 nós participamos de uma comissão criada pelo Lula, que era composta por meia dúzia de líderes sindicais e meia dúzia de intelectuais. Estavam lá pelo lado sindical o Lula, o Olívio Dutra, o Jacob Bittar, um líder sindical dos metalúrgicos de Minas e outro que era o Sicoti, que era líder em Santo André. E pelo lado intelectual estava o Chico de Oliveira, Paulo Singer, Weffort, Vinícius e eu. Essa comissão se reuniu por quase um ano no esforço de elaboração do manifesto do PT no Primeiro Programa. Este documento foi apresentado posteriormente no primeiro encontro do PT que ocorreu no início de 1980 no Colégio Sion. Ai já se tratava da fundação do PT baseada nos sindicalistas que não tinham tido militância de esquerda, nenhuma experiência na militância de esquerda.

A narrativa de Moisés acenou para os vínculos que foram construídos entre os docentes, profissionais da academia, e os movimentos sociais. Uma vez solicitados 
pelos líderes sindicais, os intelectuais se organizaram para contribuir com a formação de um partido que estava vinculado aos sujeitos históricos que eram seus objetos de pesquisa. Depois de ter se desligado do PT, Moisés trabalhou junto ao então Ministro da Cultura Francisco Weffort entre 1995 e 2002, atuando como diretor do Fundo Nacional de Cultura, além de ter desempenhado a função de Secretário de Apoio à Cultura, Secretário de Audiovisual e diretor da TV Cultura e Arte do Ministério da Cultura:

Foi muito interessante trabalhar no governo federal. Quando o Fernando Henrique montou o ministério, Isso é uma coisa engraçada no Brasil. Os presidentes no presidencialismo de coalizão, quando eles vão formar os ministérios, são obrigados a atender os vários partidos que apoiam o governo, para ter maioria no congresso. Ao mesmo tempo, no entanto, existe uma cota pessoal do presidente... É estranho, não é? A tal da cota pessoal. Bom, o Ministério da Cultura fazia parte da cota pessoal do Fernando Henrique. O Weffort foi escolhido pelo presidente e eu fui convidado pelo primeiro. Nós fomos, mas mantivemos nossa posição, o Fernando Henrique sabia que nós tínhamos nossa origem no PT e sabia que nós tínhamos críticas ao PSDB e a ele próprio.

Os argumentos de Moisés foram de entro à posição de Durham em relação à autonomia intelectual. Ou seja, o fato de ter atuado em um ministério ligado diretamente ao presidente Fernando Henrique Cardoso, segundo Moisés, não implicava em abandonar suas posições políticas e, muito menos, em abdicar de sua autonomia intelectual. Tal postura crítica, evidentemente, baseava-se também na segurança fornecida pela carreira universitária como funcionário público da USP.

A trajetória intelectual de Moisés esteve intrinsecamente atrelada a uma intensa atividade política. Ela sintetiza o impacto sofrido pelos docentes em relação à questão democrática durante o processo de transição política. O desenvolvimento de pesquisas dedicadas aos movimentos sociais, ao novo sindicalismo e, particularmente, ao tema da democracia, acompanhou a formação de uma carreira acadêmica atenta às transformações da cultura política e da sociedade brasileira contemporânea. Para Moisés, a Faculdade de Filosofia proporcionou uma formação na qual a condição de intelectual sempre esteve atrelada à do cidadão:

Saí da conferência do Ianni com a certeza de que eu tinha alguma coisa a fazer. Experiências como essas davam para nós um rumo intelectual e, por outro lado, a noção de que todos nós somos cidadãos. Não dá para separar. Nunca separei a minha condição de 
cidadão da minha condição de intelectual. O tempo todo, essas coisas estiveram de tal modo imbricadas e influenciaram uma a outra. Claro, isso coloca problemas, afinal, quando se está muito entusiasmado por desafios que são colocados na sua condição de cidadão, existe o risco de se distorcer a análise? Acho que esse risco só existe se o intelectual não for cuidadoso e rigoroso com os métodos de apuração da realidade, de levantamento de dados, de perguntas sobre os próprios dados e de indagação sobre a esfera empírica. Se o intelectual ceder aí e diante de situações difíceis não buscar informação, nesse caso há problema.

Moisés defendeu que o intelectual deve ter consciência das afinidades existentes entre as investigações acadêmicas e a presença de vínculos pessoais nas escolhas feitas em relação aos objetos de pesquisa. Nesse sentido, o envolvimento e a participação do pesquisador em atividades políticas não inviabiliza a defesa do espaço de autonomia necessário para o estabelecimento de uma avaliação criteriosa e autônoma.

Francisco de Oliveira também se destacou entre os docentes que defenderam a participação dos intelectuais em atividades político-partidárias. Para Oliveira, a atividade política sempre foi um componente fundamental à formação do cientista social, ingrediente indispensável para uma compreensão mais profunda e completa da sociedade. No seu entender, "a atividade política fecunda a atividade acadêmica e viceversa":

Acho muito positivo o encontro da atividade intelectual com a político-partidária. A maior parte dos meus colegas acadêmicos tem uma posição de rejeição ou, no mínimo, uma tentativa de neutralidade. Isso é um equívoco. No meu modo de ver a atividade política fecunda a atividade acadêmica e vice-versa. Você pode fazer atividade acadêmica sem prejuízo da atividade militante e, o contrário, a condição de militante pode ajudar muito na atividade acadêmica.

O esforço de Oliveira para se inserir no debate público esteve presente em toda a sua carreira intelectual. Tornar-se parte do quadro docente da FFLCH-USP foi consequência, portanto, do trabalho desenvolvido por Oliveira em suas pesquisas e análises sobre a sociedade brasileira, desenvolvidas principalmente durante a sua atuação no CEBRAP. "Nunca adotei uma posição neutra, isso não existe. A ciência não é neutra, a ciência toma partido. É preciso que os alunos tenham clareza sobre isso", destacou o professor. Durante a ditadura civil-militar, contribuiu para k estabelecimento da chamada imprensa nanica e de resistência que desempenhava um importante papel na publicização de análises críticas naquele contexto: 
Mas essa participação na imprensa foi muito interessante, me deu uma nova experiência e me obrigou a comunicar minhas ideais em uma linguagem acessível à população que lê jornais sem perder o rigor. Além disso, era uma oportunidade de levar os conhecimentos das ciências sociais para o campo jornalístico e aprender a divulgar ideias. Isso, infelizmente, a academia não faz muito. Ela tem, às vezes, um linguajar muito hermético, pouco exposto ao público, e isso acaba sendo um desperdício porque a academia tem muito o que ensinar. Mas os meus colegas da USP não são muito dados a debater nesses veículos. A maior parte dos professores é do estilo clássico de intelectual que não participa de debates públicos. E esse não é muito o meu feitio, eu prefiro ousar e utilizar o pouco que sei para fecundar a discussão na sociedade. Não sou um intelectual contemplante...

Ao lado de Moisés, Oliveira também participou ativamente da fundação do Partido dos Trabalhadores e descreveu essa experiência como uma oportunidade de exercício livre da política muito esperada após anos de ditadura:

Eu participei da formação do Partido dos Trabalhadores desde a primeira reunião feita no Colégio Sion. Havia lá umas duas mil pessoas, de modo que minha participação não tinha nada de especial. Mas fiz parte de um grupo de intelectuais que desde logo estava à espera dessa oportunidade. Havia no país uma espécie de orfandade em relação a atividade política... Apesar de nunca ter feito parte do Partido Comunista, sabíamos que ele ainda estava sob forte repressão... Havia uma massa enorme de pessoas que estavam em busca de uma oportunidade como essa apresentada na primeira reunião. O PT foi essa chance. Tanto que o seu primeiro secretário geral foi o Francisco Weffort, tipicamente um intelectual da USP, e que exerceu esse cargo durante muitos anos.

As trajetórias de vida acadêmica de Albuquerque, Moisés e Oliveira demonstraram como a redemocratização ampliou as oportunidades de atuação intelectual e problematizou as relações entre a universidade pública e a sociedade. A liberdade para assumir vínculos partidários ocorreu paralelamente à profissionalização da carreira docente, o que contribuiu para a elaboração de reflexões em torno do espaço público. Desse modo, a construção de instituições democráticas passava a ser agregada ao conjunto de problemas que mereciam ser avaliados pela universidade e, concomitantemente, traziam à tona a própria participação dos docentes na esfera governamental.

Dentre os professores entrevistados que ao longo da carreira acadêmica também estiveram envolvidos em práticas político-partidárias, destaca-se Messias da Costa. Por 
duas vezes candidato a reitor, incluindo as últimas eleições ocorridas no início de 2014, quando foi o terceiro mais votado, Messias da Costa desempenhou uma atividade política intimamente ligada à administração universitária:

Sou um sujeito bissexto, sempre digo que desde meu primeiro dia como aluno, sempre tive um pé na carreira acadêmica e outro pé na carreira política. Gosto de política, e considero-me político e um homem público. Não um político profissional já que nunca disputei cargo para parlamentar ou executivo... Mas sou da política e sei como ela opera. E não me envergonho disso. Valorizo e acho que as pessoas deveriam fazer mais política nesse país. Agora, como sou um sujeito da academia, professor, intelectual que escreve, pensa, viaja e participa de seminários, etc., procuro zelar pela minha produção científica, pois não quero me tornar aquele sujeito que atua na política, mas deixa de lado o fazer acadêmico. Inclusive porque no geral esse é um caminho sem volta... Tivemos até um presidente da república... Um intelectual que largou tudo e chegou a presidente! Acho muito difícil que a política partidária possa ser conciliada com a atividade acadêmica porque ela te consome vinte e quatro horas. Se o sujeito se torna, por exemplo, um vereador, prefeito ou deputado, a carreira acadêmica acabou!

Em sua entrevista, Messias da Costa enfatizou a precocidade de sua atuação na política universitária desde o ingresso no movimento estudantil ocorrido durante a graduação, como mais tarde na ADUSP e na fundação da Associação Nacional dos Docentes do Ensino Superior (ANDES). Trabalhou na campanha que levou o professor de física da USP, José Goldemberg, à reitoria desta universidade e foi convidado para dirigir a Coordenadoria de Assistência Social (COSEAS-USP). Depois disso, foi chamado para participar da administração federal pelo Prof. Goldemberg que, na época, era ministro de Ciência e Tecnologia do governo Collor. Nessa ocasião, trabalhou na Secretaria da Presidência da República, especificamente na Secretaria de Assuntos Estratégicos (SAE), onde coordenou a Comissão de Zoneamento Ecológico e Econômico da Amazônia.

Entre 1995 e 2000, Messias da Costa assumiu ainda o posto de diretor na Secretaria da Amazônia, tendo trabalhado no Ministério do Meio Ambiente com a região amazônica. Foi coordenador do Centro de Ensino e Pesquisa Aplicada (CEPAUSP) e prefeito da cidade universitária entre 2003 e 2005, período em que também atuou como um dos responsáveis pela implantação da USP-Leste. Trabalhou como chefe de gabinete na reitoria (2005-2006) e administrou a Coordenadoria de Comunicação Social da USP. Atuou ainda nos últimos anos como Superintendente de 
Relações Institucionais (2010-2014). A política universitária uspiana e as diversas funções exercidas na esfera do governo federal fizeram parte de um projeto de vida intelectual que fora traçado paralelamente à carreira acadêmica. Não é demais observar, mais uma vez, que carreiras intelectuais como a desenvolvida por Messias da Costa só foram possíveis graças à segurança oferecida pela carreira universitária pública.

Coggiola, conhecido por sua atuação como intelectual e historiador trotskista, nunca desvinculou seu trabalho acadêmico e de pesquisa da perspectiva de uma prática política engajada. Como já comentado no capítulo anterior, a atuação na militância estudantil influenciou a sua decisão de cursar história e economia:

Comecei a relacionar as questões teóricas da história ao engajamento político por intuição. Digamos assim, tenho consciência profunda do quanto as referências teóricas marxistas - tal como eram professadas nas décadas de 1960 e 1970 - foram muito questionadas e o quanto havia de dogmático, não no marxismo, senão na maneira como ele era interpretado. Portanto, a experiência política me ajudou a questionar essas leituras porque acompanhei de perto. Estudei e publiquei sobre o fim da União Soviética, sobre a Europa do Leste, a transformação capitalista da China. Trabalhei sobre todos esses temas. Ponto um, diria então que a História Contemporânea, primeiro como ensino e, depois, como eu a vejo politicamente, são uma coisa só. Ponto dois, o mesmo engajamento político faz com que eu não consiga teorizar isso. Por quê? Porque a minha atividade é feita muito no dia a dia. E para teorizar você precisa se isolar um pouco do mundo e pensá-lo sistematicamente. Eu tento, produzo, tenho uma obra, mas reconheço que ainda não consegui apresentar uma teorização sobre isso tudo.

Para Coggiola, a experiência política contribuiu para a elaboração de questionamentos a posições dogmáticas encampadas a partir de interpretações mecanicistas do marxismo. Nesse sentido, o professor considerou que a atividade política complementou a intelectual e que ambas se desenvolveram alimentando-se mutuamente.

Segundo as palavras de Coggiola, a sua trajetória caracteriza-se pelo fato de "ser o mais politizado de todos os professores de todo o departamento de História. Eu estive também no sindicalismo, o que foi uma experiência boa, embora muitas vezes chata, porque a luta por resultados te absorve muito”. Quanto a sua atuação sindical, Coggiola trabalhou por três vezes como diretor (vice-presidente) do Sindicato Nacional dos Docentes do Ensino Superior (ANDES) e, na ADUSP, atuou como vice-presidente também por três mandatos. "Atualmente faço parte da Diretoria da ADUSP e me ocupo 
do sindicato nacional. Ele tem dezenas de milhares de filiados e um monte de problemas", comentou o professor. Para Coggiola, a aproximação em relação à política universitária permitiu a aquisição de uma visão ampla da situação das universidades públicas no país e lhe conferiu a condição de avaliar in loco o desenvolvimento da profissionalização da carreira docente.

Em contraste com a atuação dos professores vinculados a atividades políticopartidárias, foi necessário ainda examinar os docentes que possuem perfil administrativo, mas não desenvolveram vínculos políticos explícitos. Isso significa que a redemocratização em parceria com o processo de profissionalização docente, permitiu o surgimento de uma atividade político-administrativa não atrelada diretamente a grupos políticos organizados. A partir desse contexto os docentes puderam desenvolver a construção de caminhos políticos independentes e, não necessariamente, vinculados a legendas e a cargos comissionados. Nesse aspecto destacam-se as carreiras de Sandra Nitrini e Sérgio Adorno que optaram por dedicar seus esforços de atuação no âmbito da administração universitária. Ambos exerceram a direção da Faculdade de Filosofia e representam dentro da comunidade docente estudada um perfil docente que se estruturou e ganhou novos contornos com a profissionalização da carreira docente.

Nitrini, professora de Literatura Comparada desde 1981, desempenhou importantes atividades à frente do Departamento de Teoria Literária e Literatura Comparada (DTLLC): "Depois da primeira chefia da qual participou o Davi e eu, a seguinte foi formada com a Prof. ${ }^{a}$ Lígia e o Prof. Lafetá. A chefia pode ficar dois anos e renovar por mais dois anos, mas essas ficaram dois anos e pronto", comentou Nitrini. Como resultado, teve que assumir a chefia do departamento mesmo sendo ainda uma professora doutora:

Daí na terceira chefia, não tinha jeito, eu tinha que ser chefe de departamento. Fui chefe e a Prof. ${ }^{\text {a }}$ Regina Pontieri vice-chefe. Esta foi a primeira chefia de departamento ocupada por um professor doutor, pois os anteriores eram ou titular ou livre-docente. Isso sobrecarrega muito um professor-doutor, que tem que preparar sua livre-docência e tudo o mais. Então fiquei na chefia por dois anos que foram renovados por mais dois anos. Fui reconduzida porque ninguém mais se dispôs a assumir este cargo. No período da chefia, procurei, com muito custo, dar continuidade à minha pesquisa e consegui me apresentar para o concurso de livre-docência na minha segunda gestão em 1996, ano em que, infelizmente, Lafetá faleceu. 
Concomitantemente à profissionalização da carreira docente, aumentaram as exigências burocráticas em relação aos departamentos da FFLCH-USP. O Estatuto da USP aprovado em 1988 determinou que os responsáveis pela direção dos departamentos tivessem como titulação mínima a livre-docência. Além disso, o próprio funcionamento dos departamentos passou a estar vinculado à necessidade de um número mínimo de professores livre-docentes e titulares, ainda que, na prática, pudessem ocorrer exceções. Resultado, as novas determinações passaram a exigir com mais ênfase dos professores pertencentes à comunidade docente pesquisada atenção em relação a uma dupla responsabilidade: a administrativa e a de pesquisador; já que a primeira não mais poderia ser ignorada sem que a segunda não fosse prejudicada.

A experiência adquirida e o interesse pela área administrativa levou Nitrini a ser vice-diretora da FFLCH entre 2004 e 2008 e diretora da mesma Faculdade entre 2008 e 2012:

\begin{abstract}
Passados alguns anos de calmaria, voltei a ser vice-chefe do DTLLC por um período de 7 meses mais ou menos. Numa tarde, estava na minha casa, estudando, lendo, quando tocou o telefone. Era uma colega do departamento, a Profa Maria Augusta Fonseca, então chefe do DTLLC, que me diz mais ou menos isso: "Olha, o Prof. Sedi Hirano, (então, diretor da FFLCH), procurou os chefes de departamento de Letras porque ele precisa de uma vice-diretora". A professora Eni de Mesquita Samara, vice-diretora, tinha sido nomeada diretora do Museu Paulista. O Prof. Sedi foi procurar um vice no curso de Letras e os chefes dos cinco departamentos de Letras me indicaram. Resisti muito. Lembro que recebi esse telefonema em novembro e resisti até fevereiro do ano seguinte. Eu não queria. Mas depois, conversa com um, conversa com outro, acabei aceitando e vim para a vice-direção. Foi uma experiência da qual não me arrependo porque fiquei conhecendo a Faculdade de Filosofia no seu todo. Essa oportunidade ampliou muito a minha visão sobre a FFLCH e sobre toda a universidade. Foi um ganho. Entendi também que participar dessas atividades significa colaborar para um trabalho acadêmico coletivo e de peso. Tenho muita satisfação de ver as grandes conquistas da nossa Faculdade e de ter colaborado num cargo que é muito trabalhoso, mas, como já disse, me trouxe grande compreensão a respeito da universidade. Pude entender melhor a universidade e conhecer as outras unidades, os colegas das outras unidades. Além disso passei a relativizar a visão de que somos o "umbigo da universidade", o "umbigo do mundo". Nós não somos.
\end{abstract}

Nitrini foi substituída por Sérgio Adorno que assumiu o cargo de diretor da FFLCH em 2012. Além de possuir uma carreira acadêmica dedicada ao Núcleo de Estudos da Violência (NEV-USP) e ao Departamento de Sociologia, Adorno teve uma 
significativa participação à frente de questões administrativas em momentos decisivos como aquele no qual se deu a divisão do curso de Ciências Sociais nos departamentos de Antropologia, Sociologia e Ciência Política, o que lhe rendeu uma experiência em gestão bastante significativa. Entre as principais atividades administrativas desempenhadas por Adorno, pode-se citar a sua atuação como vice-chefe do Departamento de Sociologia (1987-1990), como presidente da Comissão de PósGraduação da Faculdade de Filosofia e coordenador do Programa de Pós-Graduação em Sociologia (2003-2005). Em entrevista concedida durante seu mandato como diretor da FFLCH-USP, Adorno falou da necessidade de aperfeiçoar a gestão da instituição e, particularmente, de definir um projeto de futuro para a instituição:

Penso que o desenho administrativo da Faculdade tem que ser repensado. Tem certos constrangimentos que são estruturais, ou seja, não dá para você reformatar toda a FFLCH-USP porque existem estatutos e um regimento, etc. Mas ela precisa ter uma gestão diferenciada, com mais delegação e prestação de contas. Por exemplo, nós estamos conversando aqui e essa é uma das poucas oportunidades que tenho para fazer isso. Na maior parte das vezes, estou nessa mesa resolvendo problemas administrativos. Estou assinando documentos e discutindo distribuição de verbas... Agora, ter uma política geral seria importante. A coisa mais difícil é introduzir uma coisa nova na qual nós não fomos disciplinados, que é o planejamento. Inclusive, o planejamento de recursos. Nós precisamos ter planejamento orçamentário, ou seja, se tenho recursos, onde vou gastá-lo? Vou investir nos próximos dois anos em mandar aluno para o exterior para formá-los em uma escola? Ou vou criar um banco com gestão de informações? Para onde vou? Então é preciso ter um planejamento que diga o que precisa ser feito. É preciso ter um norte! A Faculdade funciona de maneira independente, creio que com ou sem diretoria, porque as pessoas são responsáveis e se identificam com o que elas fazem... Agora, é importante ter uma direção que estabeleça um eixo de trabalho.

O exame das trajetórias de Nitrini e Adorno revelaram como a preocupação com a gestão da universidade e dos recursos públicos passou a estar presente no dia a dia da comunidade acadêmica a partir da redemocratização. Para Adorno, inclusive, os docentes da Faculdade de Filosofia têm a responsabilidade de participar da organização de um planejamento orçamentário, definindo como os recursos existentes serão gastos a curto, médio e longo prazo. Segundo Adorno, essa é uma condição importante para que se regule e garanta a manutenção da instituição como um todo e, principalmente, das pesquisas. 
Em se tratando de política universitária, muitos docentes explicitaram ao longo de suas carreiras, interesse em relação às condições de trabalho acadêmico nas universidades públicas e, particularmente, na área das humanidades. Ainda sob o impacto da transição trançada da ditadura para a democracia política, Perrone-Moisés comentou a respeito de algumas dificuldades enfrentadas no sentido de democratizar as atividades na universidade, particularmente, as administrativas. Segundo a professora: "Entre as grandes questões dos anos 1980 na USP, uma delas era modificar os regulamentos que estavam completamente caducos e autoritários. Não somente por causa da ditadura, mas porque eram antigos, pertenciam ao tempo dos catedráticos". Para Perrone-Moisés, a vivência democrática influenciou a costura de novas relações no interior de uma universidade que era controlada autoritariamente:

Nesse período o diretor da Faculdade foi uma pessoa admirável, o Prof. Rui Coelho. Lembro que, nas reuniões do Conselho Interdepartamental com o diretor, havia constantes problemas de choque com o regulamento. O Rui Coelho, muito diplomata, dizia que era preciso descobrir uma maneira de "contornar" a questão. Seu objetivo era introduzir mudanças sem entrar em choque com a reitoria. Eu mesma, quando fui chefe de departamento, reuni os 79 professores da Letras Modernas que queriam ter reuniões abertas, plenárias. Isso não existia porque eram somente os titulares e um representante de cada categoria que participavam do Conselho Departamental. Começamos a fazer as reuniões plenárias em um anfiteatro da História ou da Geografia. Essas reuniões plenárias eram feitas às claras, para todos. O que aconteceu? Um dos titulares de direita do meu departamento entrou com uma representação contra mim junto à reitoria, dizendo que eu estava infringindo o regulamento que, segundo ele, proibia plenárias. Na verdade ele não proibia, somente não previa. Como era já uma época de abertura política, tive de fazer um arrazoado para me defender. Deu trabalho, mas as plenárias continuaram. Depois as plenárias foram adotadas em todos os departamentos.

Perrone-Moisés atuou como docente de Língua e Literatura Francesa e foi chefe do departamento Departamento de Letras Modernas da FFLCH-USP entre 1985 e 1987. Além de ter trabalhado na defesa de uma ampla participação dos professores nas decisões administrativas nos anos 1980, Perrone-Moisés reivindicou algum tempo depois em um artigo audacioso, o reconhecimento público do papel social e político desempenhado pelas ciências humanas: 
Na época da questão dos improdutivos escrevi um artigo chamado "Para que servem as Humanidades?"120. Nele tentei explicar que elas servem para que a universidade continue a ser, além de um local de pesquisas científicas e tecnológicas, um lugar onde se exerce também o pensamento crítico, sem o qual esses avanços procederiam às cegas. Sem a compreensão da história dos homens, de seu habitat natural e social, de suas línguas, culturas e religiões, as conquistas científicas e tecnológicas são utilizadas ou inviabilizadas num mundo guerreiro e repartido de forma injusta. As humanidades servem para pensar a finalidade e a qualidade da existência humana, para além do simples alongamento de sua duração ou do bem-estar baseado no consumo e nas metas do FMI. Servem para estudar os problemas de nosso país e do mundo, para humanizar a globalização. Tendo por objeto e objetivo o homem, a capacidade que este tem de entender, de imaginar e de criar, esses estudos servem à vida tanto quanto a pesquisa sobre o genoma.

Em "Para que servem as Humanidades?", Perrone-Moisés abordou questões sensíveis às ciências humanas em tom de desabafo intelectual e, por que não, de manifesto político em defesa da retomada da perspectiva humanista para a sociedade nos dias atuais e na elaboração de seus projetos futuros. A publicização de artigos em tom de manifesto passou a ser a maneira encontrada por alguns docentes para quebrar as barreiras burocráticas que sufocam o mundo acadêmico e tentar atingir o grande público, chamando a atenção para a importância dos compromissos existentes entre a universidade e a sociedade.

As diferentes ênfases adotadas pelas trajetórias de vida acadêmica indicam que os docentes desfrutaram efetivamente da liberdade intelectual que afirmaram ter enquanto funcionários públicos. Mais do que uma resposta precisa a respeito de qual deveria ser o papel ideal dos intelectuais no mundo contemporâneo, os professores demonstraram que o verdadeiro usufruto da autonomia significou poder escolher as atividades a serem desenvolvidas dentro e fora da universidade e o rumo de suas carreiras acadêmicas.

Alessandri Carlos, em recente manifesto contra o produtivismo acadêmico, abordou o problema das condições de trabalho dos professores universitários diante do número de tarefas e cobranças periódicas que, segundo ela, deslocaram o foco da pesquisa e do ensino e transformaram o cotidiano docente em um emaranhado de tarefas burocráticas. As questões trazidas por Alessendri Carlos serão discutidas no próximo

\footnotetext{
${ }^{120}$ Perrone-Moisés, L. "Para que servem as Humanidades?”. Folha de S. Paulo, “Mais!", 30/06/02, p. 9 a 10.
} 
tópico, já que o tema da produção, da avaliação e do produtivismo acadêmico podem, justamente, comprometer no tempo presente a autonomia que tanto defenderam os professores em suas trajetórias.

\subsubsection{Produção acadêmica: avaliação docente e produtivismo.}

As entrevistas de história oral de vida acadêmica permitiram compreender desde as relações cotidianas vividas pela comunidade pesquisada no interior do processo de profissionalização da universidade pública, bem como as características mais marcantes da carreira, a exemplo da estabilidade do funcionalismo público e seus efeitos sobre o trabalho docente. Fugindo de concepções antinômicas, o presente estudo defende que o processo de profissionalização da atividade acadêmica no interior da universidade pública brasileira precisa ser pensado enquanto um campo conflituoso, repleto de possibilidades, dentre as quais a de construção de um espaço que permitiu o desenvolvimento da autonomia intelectual. A hipótese que guiou as investigações sobre a trajetória dos professores foi a de que enquanto funcionários públicos de carreira, os docentes puderam desenvolver concepções autônomas capazes de resistir a medidas burocráticas impostas pelo Estado.

Durante a longa fase de consolidação da democracia política no Brasil, as decisões em relação ao papel da universidade pública estiveram longe de estar isoladas em uma via de mão única, determinadas de cima para baixo. A comunidade docente pertencente à FFLCH-USP vivenciou todas as etapas que fizeram parte do longo processo de implementação da avaliação das universidades públicas e de seus professores. Dessa maneira, mais do que investigar como as políticas públicas atingiram a universidade tarefa já realizada com êxito por diversos pesquisadores -, o exame das entrevistas procurou compreender como os docentes participaram ativamente da institucionalização do sistema de avaliação do ensino superior, vezes como atores coadjuvantes, vezes como protagonistas, mas nunca como meros figurantes.

As primeiras iniciativas no sentido de promover a avaliação dos cursos de pósgraduação no Brasil, portanto, dos docentes orientadores e dos pesquisadores das universidades públicas brasileiras, foram praticadas no ápice do processo de transição 
trançada da ditadura para a democracia política. Os passos iniciais no sentido de sistematizar a avaliação da pós-graduação foram idealizados pela CAPES na gestão de Claudio de Moura Castro, diretor dessa agência entre 1979-1982. Pouco mais tarde, novas propostas surgiram a partir da contribuição dos relatórios escritos por Simon Schwartzman durante o governo Tancredo Neves.

A introdução definitiva do tema da avaliação universitária no contexto acadêmico nacional, no entanto, foi impulsionada pela publicação em 22 de fevereiro de 1988 da chamada "Lista dos improdutivos" em um jornal de circulação nacional, a qual contava supostamente com o nome de professores da Universidade de São Paulo que não teriam publicado no biênio 1985/86. Originalmente, a matéria da Folha de São Paulo intitulava-se "Relação de docentes sem produção científica entre 1985/86" e continha 1108 nomes de professores da USP considerados "improdutivos".

A reitoria, comandada pelo Prof. Goldemberg na época da publicação, foi acusada de encaminhar propositalmente para a Folha de São Paulo a lista com os nomes de seus professores. Segundo alguns professores entrevistados, a maneira como um relatório interno - cujos critérios não eram suficiente claros - acabou chegando ao grande público, antes mesmo de ter sido debatido internamente, foi compreendida como uma forma de pressão e uma afronta à comunidade docente. O lema "publish or perish" começava, assim, a ganhar contornos palpáveis no âmbito nacional e acabaria interferindo no cotidiano docente de maneira definitiva. A lista que divulgava os nomes dos chamados "professores improdutivos" passou a delimitar os contornos de uma nova agenda para a universidade, trazendo para o léxico acadêmico nacional a questão da produção e da avaliação a partir desse fatídico episódio.

Desde então, a USP e outras universidades públicas no país, passaram a ser alvo permanente de avaliações que procuram situá-las em rankings no contexto nacional e internacional. Boa parte dos países europeus e latino-americanos tem suas universidades públicas avaliadas pela Times Higher Education que, bienalmente, elabora um ranking comparativo internacional entre universidades. Esse ranking determina através de parâmetros próprios quais as instituições que ainda estão presas a "modelos antiquados de produção do conhecimento" e quais estão "atualizadas aos novos padrões de exigência do mercado internacional" e são capazes de agregar valor econômico a suas pesquisas. 
No hanking global estabelecido pela Times Higher Education e publicado no biênio 2012/2013, a USP aparecia como a única latino-americana entre as 200 melhores, ocupando a posição de número $178^{121}$. Apesar do crescimento dos investimentos privados e da implementação de inúmeras políticas de gerenciamento do conhecimento terem atingido o cerne das universidades públicas desde o regime militar, ironicamente, a USP ainda é considerada uma universidade "ultrapassada" por boa parte dessas agências. Outros artigos publicados em que revistas como a "The Economist" enalteceram os resultados obtidos e lembraram que a USP estaria se tornando referência mundial em medicina tropical e biocombustíveis. A Times, no entanto, se posicionou contra a própria concepção de universidade pública existente no Brasil, questionando, inclusive, o financiamento exclusivamente estatal dessas instituições. A mesma publicação ainda acrescentou em suas observações que no caso das universidades públicas brasileiras "os estudantes não pagam nada, os funcionários não podem ser demitidos e o currículo é antiquado e politizado" $" 122$.

Para alguns experts internacionais em educação e suas agências peritas em apontar soluções que visam à inserção de instituições de ensino e pesquisa no mercado, as universidades públicas brasileiras se preocupam demais com temas "antiquados e politizados" e, por isso, possuem dificuldades em se tornarem economicamente produtivas. Afinal, muitas dessas agências especializadas em avaliar o ensino superior na Europa e nos Estados Unidos, têm defendido que as universidades, prioritariamente, devem ser economicamente viáveis. Na prática, esse modelo tem categorizado o desempenho acadêmico das instituições através da sua capacidade de patentear produtos e atender a exigências específicas de mercado. Esse padrão, por sua vez, colocou a questão da propriedade intelectual entre as mais debatidas internacionalmente e as que têm rendido a maior quantidade de publicações.

J. G. Wissema, especialista em reestruturação acadêmica e história das instituições universitárias, elaborou um estudo apontando a "evolução" dessas instituições e propondo diferenciá-las em modelos ou fases distintas. Resumidamente, as chamadas universidades de Segunda Geração (2GU), estariam presas a um modelo ultrapassado de universidade porque somente se preocupavam com a pesquisa pura e não exploravam

\footnotetext{
${ }^{121}$ No biênio 2013/2014 a USP teria perdido posições no ranking segundo essa instituição, tendo sido locada entre as 250 instituições mundiais. Ver: http://www.timeshighereducation.co.uk/world-universityrankings/2011-12/world-ranking/institution/university-of-sao-paulo. Consultado em 02/07/2014.

${ }^{122}$ Folha de São Paulo, Morris Kachani, B 7, 16/10/2011.
} 
economicamente os resultados alcançados. As instituições consideradas desatualizadas também foram denominadas de "Universidades Humboldt" porque consideradas "santuários de ciência pura" e por defenderem a "ciência pela ciência", permanecendo para o autor "presas à ideia de progresso científico como objetivo". O autor enfatizou ainda que as principais inovações tecnológicas do século XVIII e XIX tais como rádio, ferrovias, telégrafo, eletricidade, telefone, fotografia, não foram desenvolvidos nos domínios desse modelo de universidade encerrado em si mesmo, mas no reino de inventores empresários e seus financiamentos. ${ }^{123}$ As concepções de Wissema permitem deduzir que as universidades de Segunda Geração estavam distantes das necessidades impostas por um mundo em franco progresso tecnológico e que isso não pode se repetir no tempo presente.

Já as universidades de Terceira Geração (3GU) seriam aquelas que atualmente perseguem e buscam explorar ou comercializar o conhecimento que produzem. Ao basearem-se em princípios tais como hierarquia, disciplina, quantidade e performance, essas instituições procuram transformar seus professores e pesquisadores em típicos profissionais prontos e capacitados para desenvolverem negócios científicos, tais como empresários capitalistas que precisam justificar através de critérios pragmáticos seus investimentos financeiros. Em relação aos alunos, procuram desenvolver uma “formação ativa", estimulando a capacitação de competências que visam à preparação de tecnostarters: estudantes capazes de desenvolver sua própria empresa de tecnologia.

Entre os principais resultados provenientes do estudo desenvolvido por Wissema com o intuito de reorganizar as universidades de Segunda Geração foi a elaboração de uma receita chamada de "carrossel do conhecimento", composta por 7 mandamentos indispensáveis para o aprimoramento de instituições ultrapassadas: a pesquisa científica e a educação devem estar atreladas a departamentos de companhias e a organizações de suporte profissionais que, por sua vez, ligadas a um financiamento infraestrutural são responsáveis pela formação de technostarters capazes de atuar ou fundar novas instituições privadas, fechando-se o ciclo. A seguir, podem ser observados os 7 mandamentos escritos por Wissema, "as tábuas sagradas" que revelam as características essenciais responsáveis pelo sucesso das universidades de Terceira Geração:

\footnotetext{
${ }^{123}$ WISSEMA, J. G. Towards the Third Generation University. Cheltenham: Edward Elgar Publishing Limited, 2009, p. 14.
} 
1 - aquelas que exploram o conhecimento produzido como um núcleo de negócios.

2 - operam em um mercado competitivo internacional;

3 - são abertas e colaboram com vários parceiros;

4 - desenvolvem pesquisas transdisciplinares;

5 - são organizações multiculturais: oferecem educação de massa e de elite;

6 - são universidades cosmopolitas;

7 - não são financiadas diretamente pelo Estado e não são dirigidas pelo Estado.

E. P. Thompson foi um dos primeiros intelectuais na Inglaterra a denunciar a existência de interesses corporativistas interferindo em decisões de pesquisa acadêmica e a se contrapor a universidades que passaram a optar pela adoção de convênios com indústrias subordinando-se a seus interesses. Em texto publicado pela primeira vez em 1970, Thompson descreveu com detalhes o processo através do qual a Universidade de Warwich passou a enquadrar-se na lógica de mercado que infestava a Inglaterra na década de 1960, inserindo seus pesquisadores em práticas acadêmicas instrumentalizadas ${ }^{124}$.

No Brasil, muitos intelectuais se insurgiram contra o avanço de interesses empresariais, corporativos e particulares no interior das universidades públicas ${ }^{125}$. Observando as contradições inerentes ao processo de implantação de projetos avaliativos em relação à universidade, o professor Octávio Ianni constatou em algumas análises a respeito do ensino superior no Brasil a transferência de procedimentos típicos da empresa capitalista para as universidades:

Transferem-se para o trabalho intelectual os mesmos critérios pragmáticos que fundamentam a organização e a eficácia da empresa industrial: racionalização, burocratização, divisão social do trabalho, especialização, hierarquia, disciplina, performance, economicidade, etc. Science is measurement. As relações e estruturas 'racionais' que se impõe ao processo de

\footnotetext{
${ }^{124}$ THOMPSON, E. P. "The Business University". In: Writings by Candlelight. London: Merlin, 1980, p.14. Segundo seu relato, o Conselho Universitário em Warwich era formado por pelo menos 9 representantes de investidores privados. Thompson frisou que esse não se tratava de um mero caso local, mas representava o problema de toda uma nação.

${ }^{125}$ FERNANDES, F. O desafio educacional. São Paulo, Cortez, 1989; GENTILI, P. \& APPLE, M. Pedagogia da exclusão: crítica ao neoliberalismo em educação. São Paulo: Vozes, 1997; SILVA, T. T. (Org.). Escola S. A. Quem ganha e quem perde no mercado educacional do neoliberalismo. Brasília: Confederação Nacional dos Trabalhadores em Educação, 1996.
} 
produção científica acabam por conferir uma segunda natureza à ciência. Ao mesmo tempo, a ciência é transformada numa técnica de poder e numa força produtiva; ela entra direta e amplamente na reprodução das relações e estruturas de dominação política e apropriação econômica ${ }^{126}$.

A consolidação e a profissionalização das carreiras docentes, a manutenção das garantias e do repasse de verbas públicas ratificadas pelo Decreto $\mathrm{n}^{\circ} 29.598$ de 2 de fevereiro de 1989 - que determinou a conquista da plena autonomia financeira para as universidades estaduais -, bem como a atuação dos professores, impediram que a Faculdade de Filosofia submetesse seus desígnios a qualquer interesse exógeno que postulasse a defesa da razão instrumental ${ }^{127}$.

Em certo sentido, a acusação que paira sobre a USP e, em particular, sobre a sua Faculdade de Filosofia, de trabalhar com um "currículo antiquado e politizado", aponta justamente para a existência de diferentes formas de resistência adotadas pela comunidade acadêmica formada entre a ditadura e a democracia, capazes de impor limites às novas exigências impostas à universidade. Ao qualificarem a USP como antiquada, algumas agências avaliadoras estiveram, na verdade, expressando seu descontentamento em relação à manutenção de currículos que asseguram o acesso aos conhecimentos clássicos e humanistas e procuram articulá-los com o atual contexto sócio-político e econômico de forma a propor interpretações críticas e sugestões que atendam as necessidades dos cidadãos e contrariam interesses econômicos particulares.

Diante das preocupações apontadas por intelectuais como Ianni, Fernandes, Matos e Thompson, a comunidade docente foi questionada em relação à sua posição a respeito das acusações de improdutividade feitas em relação a vários professores da Universidade de São Paulo em 1988, quando da primeira iniciativa de avaliação e

\footnotetext{
${ }^{126}$ IANNI, O. Sociologia da Sociologia - o pensamento sociológico brasileiro. São Paulo, Ática, 1989, p.224.

${ }^{127}$ Olgária Matos definiu com propriedade o significado de razão instrumental e suas consequências para o campo da ciência: "Na Dialética do Esclarecimento, Adorno e Horkheimer explicam as consequências da ciência moderna e da razão instrumental, que pretende o domínio da natureza para fins de produção, de consumo e de produção tecnológica, concepção negativa da técnica que só procura vencer a importância originária do homem diante da natureza, esta sempre mais forte e ameaçadora. Saber é poder, domínio da natureza é progresso. A ideia de progresso identifica progressos da ciência e da técnica com o progresso da humanidade, dissimulando suas regressões". In: MATOS, O. F. C.. Benjaminianas: cultura capitalista e fetichismo contemporâneo. São Paulo: UNESP, 2010, p. 72.
} 
quantificação da produção acadêmica. Pediu-se aos docentes que comentassem sobre a questão da produção acadêmica e em relação aos perigos do produtivismo ${ }^{128}$.

A comunidade docente em questão vivenciou um período de transição no sentido de ter sido a primeira a ter experienciado as transformações propostas pela profissionalização iniciada ainda durante a ditadura civil-militar, bem como o posterior impacto das mudanças promovidas pela discussão em torno da questão da avaliação do ensino superior e da pós-graduação, que culminariam no debate em torno da chamada “lista dos improdutivos” publicada em 1986 pela Folha de São Paulo. A publicação da listagem com os nomes dos professores considerados "improdutivos", durante a administração de José Goldemberg na reitoria da USP, provocou um amplo debate nas páginas do próprio periódico. Não caberá aqui retomar o teor dos embates e os nomes envolvidos naquele contexto, o que já foi feito por outros autores ${ }^{129}$. O objetivo de trazer à tona esse episódio junto aos docentes entrevistados foi o de avaliar o impacto dessa crise junto à comunidade docente, já que os professores da Faculdade de Filosofia destacaram-se ao terem desempenhado uma participação direta diante desse fenômeno original que inseria novos desafios à universidade e ao trabalho acadêmico.

Observou-se no conjunto das narrativas sobre o episódio da "lista dos improdutivos" que à medida que os docentes defenderam a avaliação do trabalho acadêmico por considerarem que os investimentos públicos locados nas universidades precisam ser transparentes e passíveis de análise pelos cidadãos, constatou-se igualmente na memória coletiva dessa comunidade uma forte resistência à implantação de práticas produtivistas. Em geral, os docentes entrevistados fizeram questão de diferenciar a questão da produção acadêmica, considerada necessária e legítima, da simples exigência de se produzir cada vez mais. Tributários de outro modelo de formação vinculado a práticas anteriores ao processo de institucionalização da carreira docente, a lógica produtivista sofreu sérias resistências. A concepção de mérito

\footnotetext{
${ }^{128}$ Entende-se por produtivismo o conjunto de práticas acadêmicas baseadas em uma concepção instrumental de universidade e de produção de conhecimento. Nos termos definidos por Irene Cardoso: "A universidade inserida na lógica do capital como produtora de uma ciência que se converte em força produtiva configura-se como uma instituição subordinada à uma gestão econômica tecnicamente viável". Ver: CARDOSO, I. Para uma crítica do presente. Op., cit., p. 67.

${ }^{129}$ O artigo de Maria Luisa Sandoval Schmidt retoma o contexto e questões significativas do debate com muita propriedade. Ver: SCHMIDT, M. L. S. Avaliação acadêmica, ideologia e poder. Psicologia USP, v. 22, 2011, p. 315-334. Ver também: CATANI, A. \& DOURADO, L. F.. Universidade Pública-Políticas e identidade institucional. Campinas: Autores Associados, 1999. Ver também: LIMA, L. C.; AZEVEDO, M. L. N. de; CATANI, A. M.. "O processo de Bolonha, a avaliação da educação superior e algumas considerações sobre a Universidade Nova”. Avaliação (Campinas), v. 13, p. 7-36, 2008.
} 
acadêmico herdada pela comunidade docente estava baseada em uma perspectiva pública, através da qual eram consideradas relevantes as pesquisas que interrogavam a sociedade e apresentavam sugestões capazes de projetar análises críticas e significativas ao conjunto da população. Trata-se, dessa maneira, de uma comunidade formada por docentes que cultivaram e aprenderam a respeitar uma temporalidade que não atendia à velocidade imprimida pela profissionalização.

$\mathrm{Na}$ cultura acadêmica assimilada pela comunidade docente, o carreirismo sempre foi condenado intelectualmente e interpretado como sinal de pouco cuidado com a realização de pesquisas consistentes e significativas para a construção do conhecimento crítico e socialmente relevante. Possivelmente, somou-se a essa herança o fato de que havia um pequeno número de doutores e uma baixa competitividade por vagas, o que teria dificultado o avanço de propostas produtivistas durante o processo de instalação da profissionalização da carreira acadêmica. Segundo Sandra Nitrini, havia um grande receio que o rápido avanço na carreira pudesse ser interpretado como "carreirismo". Afinal, a regra informal estabelecida pelos pares defendia que era salutar esperar o momento adequado para se apresentar um trabalho acadêmico considerado maduro, respeitando o público leitor e contribuindo para fortalecimento do debate teórico:

Eu não queria defender a livre-docência antes do Lafetá. ${ }^{130}$ Ele tinha sido o meu examinador de doutorado e era professor da Área há muito mais tempo que eu. Naquela época a gente tinha esse tipo de preocupação. Hoje essa não é mais a mentalidade dominante. Logo

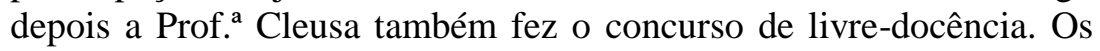
titulares estavam se aposentando, tínhamos pouca gente. Lembro muito bem que numa reunião da Congregação quando eu era chefe, a Prof. $^{a}$ Raquel Glezer, que era representante da Congregação no Conselho Universitário, trouxe informações sobre os departamentos que estavam perigando porque não tinham o número adequado de professores e nem mesmo as categorias proporcionalmente adequadas. Um desses departamentos era o de Teoria Literária. Os dois últimos titulares do Departamento, Prof. Davi e a Prof. ${ }^{a}$ Lígia, tinham acabado de se aposentar. Para o departamento existir, tinha que ter pelo menos dois titulares. Resultado, tanto eu quanto a minha colega Cleusa, tivemos que fazer o concurso de titular no prazo de um ano e meio ou dois depois do concurso de livre-docência. Isso nos incomodou muito porque parecia que éramos carreiristas, mas foi uma junção de situações que nos obrigou a isso, inclusive para manter o Departamento de Teoria Literária e Literatura Comparada.

\footnotetext{
${ }^{130}$ João Luiz Machado Lafetá (1946-1996) foi professor do Departamento de Teoria Literária e Literatura Comparada entre 1978 e 1996.
} 
As palavras de Nitrini atestaram o surgimento de situações de tensão vividas pela comunidade docente que foram introduzidas pela profissionalização e pelas novas exigências estatutárias, explicitando o contraste entre a vida acadêmica anterior e aquela que foi se estruturando paralelamente à institucionalização da carreira. Muitos docentes expressaram esse estranhamento em relação às mudanças na carreira e aos novos modos de avaliar o trabalho acadêmico e, em virtude disso, conseguiram estabelecer mediações que foram capazes de evitar a assimilação acrítica das mudanças.

A entrevista com Davi Arrigucci Jr. possibilitou conhecer a posição de um docente que acompanhou os diferentes estágios de implantação da pós-graduação e, particularmente, a redução dos prazos para a realização das pesquisas. Arrigucci fez questão de destacar sua experiência e os laços estabelecidos com uma temporalidade comprometida com as necessidades do trabalho acadêmico na área de humanidades. Arrigucci ressaltou ainda a importância de o intelectual ter autonomia para cultivar o conhecimento respeitando as diferentes fases de maturação de uma pesquisa:

Quando passei para Teoria Literária houve a mudança da pósgraduação para o novo regime. Antonio Candido havia dado aulas de especialização no regime anterior também, o antigo, quando do início dele na Maria Antônia. Aí veio o regime novo que reestruturou a pósgraduação, podemos dizer, como até outro dia. Não havia uma obrigação férrea do mestrado, e fiz direto o doutorado. Como já estava com um trabalho muito adiantado não cogitei fazer o mestrado e fui direto para o doutorado. (...) Eu levei uns seis ou sete anos para escrever a tese de doutorado. Demorou porque entrei em 1968 e só a defendi em 1972, quatro anos depois de ter entrado na Teoria Literária. Mas eu já estava há anos no espanhol estudando esse escritor argentino. O primeiro artigo que eu escrevi no Suplemento Literário do Estado de São Paulo sobre o Cortázar é de 1966, quer dizer, levei ainda seis anos até escrever em 1972 o Escorpião Encalacrado. Era um prazo longo, fruto de um processo decantado e demorado que tomou muitos anos. Esse artigo era sobre o primeiro conto publicado pelo Cortázar, chamado "Casa tomada". Conto publicado pelo Borges em 1947, na revista da Biblioteca que ele dirigia. Uma revista mais ou menos secreta, segundo disse... Porque ninguém a lia!

As pesquisas elaboradas por Arrigucci foram construídas graças a um tempo de maturação intelectual permitido pela carreira acadêmica desenvolvida em uma universidade pública durante o contexto de transição política. Os vários desafios esboçados por Arrigucci ao longo de sua carreira só foram possíveis porque suas decisões contavam integralmente com o tempo necessário para se conhecer em 
profundidade as obras e os autores que seriam trabalhados. Intui-se a partir da fala de Arrigucci Jr. que houve condições plenas para que todas as etapas de seu processo de formação intelectual ocorressem. Tal formação intelectual compreendia uma prática acadêmica que integrava a condição de pesquisador e aprendiz, segundo a qual era salutar: ler, decantar, estabelecer problemas, escrever, errar, reelaborar, publicar, dialogar com o público e seus pares, tomar novos caminhos e receber críticas. Nesse sentido, a obra intelectual de Arrigucci Jr. pode ser considerada "expressão de uma experiência lentamente assimilada":

Mas tem que haver lá também um corpo docente que funcione e decerto há. Pode ter lá um lastro de nulidades que é difícil de levar, mas há lá os que fazem e puxam o comboio. E são esses é que decidem as coisas e o avanço do conhecimento! Por outro lado, o tempo exigido para que se cumpra uma tarefa é diferente nas ciências humanas e nas exatas. O que quero dizer é que o tempo de absorção, o tempo de decantação e o tempo de escrita são diferentes também. Nas Ciências exatas, o método de trabalho tem exigências distintas das humanas, o que resulta em diferenças específicas quanto ao tempo de cumprimento de um projeto de pesquisa. Ou seja, você coleta dados, faz a pesquisa no laboratório, chega aos pontos relevantes, tendo reunido material suficiente, e escreve. É muito diferente de quando você escreve um ensaio literário, que depende de outro tipo de sedimentação do conhecimento e de outro tipo de escrita. Escrever é sempre difícil para todos, mas os ritmos de um ensaio de interpretação literária quando se trata de um livro muito complexo ou de um conjunto de livros, depende de um tempo distinto, que tem a ver com o acúmulo e a expressão da experiência lentamente assimilada, o que determina diferenças em relação ao tempo de execução da escrita. Mas se você pegar a relação de conjunto e, a longo prazo, verá que todos fizeram coisas, inclusive, aqueles considerados improdutivos. Essa lista foi uma balela, uma piada de mau gosto, uma bobagem jornalística.

A publicação da listagem com o nome dos professores considerados improdutivos no biênio 1985/86 apresentava critérios considerados falhos porque não abrangiam o trabalho acadêmico em sua integralidade. Além disso, muitos docentes que haviam trabalhado no ensino, na orientação, extensão e redigido artigos no período postulado, tiveram seus nomes estranhamente citados naquela lista. Nesse sentido, a avaliação provocou perplexidade, impotência e um sentimento de desrespeito que tomou conta de quase toda comunidade docente uspiana. Sandra Nitrini relembrou o mal estar provocado por aquela publicação baseada em um relatório feito pela então reitoria: 
Quando saiu a chamada Lista dos Improdutivos, eu tinha acabado de defender o doutorado. Minha defesa ocorreu em 1984 e meu nome saiu na Lista dos Improdutivos. Muitos professores se deixaram afetar por isso. Esse foi um momento marcante na nossa vida acadêmica na USP e na Faculdade de Filosofia. Esse fato determinou muito as mudanças, conjugado evidentemente com as políticas da CAPES e do CNPq. Agora, eu não me deixei abalar. Fiquei perplexa, mas tranquila. Muitos colegas ficaram extremamente abatidos, ficaram abalados mesmo.

Para a memória coletiva da comunidade docente a "lista dos improdutivos" foi prejudicial para a introdução da questão da avaliação docente. A inexistência de critérios que levavam em conta a complexidade do trabalho acadêmico e todas as suas esferas, deixou um legado traumático que gerava dúvidas em relação aos processos avaliativos e seus benefícios para a comunidade acadêmica. Algumas das marcas deixadas por esse episódio podem ser também observadas nas palavras de Sandra Vasconcelos:

Eu tinha acabado de entrar na universidade quando aconteceu aquele episódio da Lista dos Improdutivos. Você imagina o susto!? O meu nome estava na lista! O meu estava junto com o nome de gente muito prestigiosa. Eu não me senti nem um pouco insultada por constar na lista. Primeiro porque eu era uma jovem mestra e estava em inicíssimo de carreira! Quer dizer, você cobrar de alguém que está entrando na universidade e ainda está se situando?! Fora isso, tem um outro detalhe, eu era professora em tempo parcial, o meu tempo integral na Universidade de São Paulo só foi concedido em 1985. Então entre 1984 e 1985 eu dava 12 horas de aula. Ponto, parágrafo: Não tinha sequer a obrigação de ter uma produção. Em 1985, quando saiu meu tempo integral, foi que fiz um projeto de pesquisa e comecei a me articular para de fato entrar na carreira no sentido de uma professora em tempo integral e dedicação exclusiva. Ai, logo depois, meu nome apareceu na lista. Pensei, bom, eu não devo, então não tenho que temer nada. Em primeiro lugar, não me senti absolutamente responsável e culpada por essa situação. E, segundo, fiquei satisfeita em saber que estava em muito boa companhia naquela lista. Tinha nomes ali que você fala: como é que essas pessoas foram parar nessa lista!? O Goldemberg tentou se justificar... Teve mil coisas. Mas, de fato, aquilo produziu um trauma. Porque me lembro do clima na época. Muita gente se sentiu insultada, muito insultada.

A "lista dos improdutivos" representou para a memória coletiva da comunidade docente uma forma precipitada e pouco criteriosa de inserção do debate sobre avaliação no meio universitário, combinada a interesses que engrossavam o caldo de argumentos contra a gestão pública e seus funcionários. Além disso, se os debates iniciais contaram 
com ampla cobertura e divulgação midiática em nível nacional, com o passar do tempo eles passaram a ser travados internamente, transferidos para a esfera quase imperceptível do cotidiano acadêmico. Nesse sentido, as memórias docentes podem apontar para detalhes desse processo de convívio com as novas propostas de avaliação e, ao mesmo tempo, as formas de resistência que foram desenhadas contra a adoção de avaliações quantitativistas na universidade.

Para Leopoldo e Silva o episódio da chamada "lista dos improdutivos" não teve o mérito de trazer a questão da avaliação da produção acadêmica para o centro dos debates e, além disso, colocou em pauta uma concepção imatura e autoritária de julgamento das atividades universitárias:

Durante a redemocratização, o pessoal entusiasmado com tudo aquilo, bolou uma maneira de interferir. Já que não se podia eleger o reitor, começou a se fazer uma eleição informal com grande participação e uma lista com os mais votados era elaborada na esperança do Conselho Universitário respeitar a escolha. Hoje nem isso acontece mais. Na época, por ser o primeiro caso e pelo fato do Goldemberg ser uma pessoa de extrema habilidade política, ele conseguiu se fazer aceito nesta comunidade - que o elegeu democraticamente -, e também na eleição oficial. Ele conseguiu ser desejado por todos! Ai ele começou a colocar em prática, respaldado em tudo isso, a sua ideia de universidade que passava por questões como o produtivismo e a organização de certo empenho na gestão da universidade propriamente dita. Mas a ênfase no produtivismo era bastante grande. Isso resultou na tal lista dos improdutivos que foi um episódio célebre e lamentável. Eu pertencia ao Conselho Universitário na época e acredito que o Goldemberg somente se expôs porque tinha absoluta certeza de que nada iria acontecer a ele. Quando a coisa começou a engrossar de vários lados, até mesmo em setores próximos - porque foi uma coisa muito escandalosa -, ele costumava rir e dizer: "O reitor é inamovível. O reitor só pode ser demitido pelo governador". Na verdade, a gente ficou sabendo depois que não poderia ser demitido nem mesmo pelo governador. Ele é nomeado pelo governador, mas não pode ser demitido. Ele pode sair se ele quiser ou se acontecer uma coisa gravíssima como roubar... Mas não por questões desse tipo. Então ele tinha a certeza de que nada iria acontecer e que isso iria gerar um ambiente positivo. Evidentemente não foi isso que aconteceu, muito pelo contrário. Acirraram-se as reações a esse tipo de exigência.

Para a memória coletiva da comunidade docente a administração do reitor José Goldemberg esteve intimamente ligada à gestão de propostas que promoveram a catalisação de mudanças na organização e avaliação do trabalho acadêmico. Enquanto uma parte dos docentes entrevistados criticou a maneira como o problema da avaliação foi colocado em pauta, atacando em particular os critérios adotados pela "lista dos 
improdutivos", outros preferiram - mesmo criticando os métodos -, destacar os avanços promovidos por sua administração e a importância das medidas avaliativas propostas.

Nas palavras de Leopoldo e Silva, que atuou no Conselho Universitário fazendo oposição à administração Goldemberg, este foi um período de transformações significativas na vida universitária:

Foi incrível ver a máquina funcionando e ver como o Goldemberg pode fazer o que fez... Ele conhecia muito bem aquele organismo e sabia o que podia fazer. O Goldemberg era muito inteligente. A gênese histórica de tudo isso ainda esta para ser devidamente avaliada. Creio que do ponto de vista histórico ainda não se deu a devida importância à gestão do Prof. Goldemberg. Ele foi o iniciador, o grande promotor dessas mudanças e o primeiro reitor eleito democraticamente.

Os professores pertencentes à comunidade docente estudada foram testemunhas oculares de todo o processo de transformação do cotidiano universitário que teve início com a instalação do novo regime de pós-graduação implantado em 1969 e seus desdobramentos posteriores estabelecidos já no período de redemocratização política. A "lista dos improdutivos" levou os docentes a executarem periodicamente um cuidadoso registro de todas as atividades acadêmicas desenvolvidas, com o intuito de protegeremse de uma possível nova lista sobre a improdutividade. Em um curto espaço de tempo, a Plataforma Lattes desenvolvida pelo $\mathrm{CNPq}$, resolveria em parte essa questão, universalizando as informações referentes à produção docente e tornando-se uma referência nacional. Logo, também, a comunidade docente teve condições de perceber que o que estava em jogo não era suas próprias carreiras ou pesquisas, mas a dos futuros professores e de seus orientandos que tiveram que se adaptar às novas exigências, principalmente no que diz respeito à redução dos prazos de realização de mestrados e doutorados e dos períodos das respectivas bolsas. Ironicamente, os docentes que haviam realizado seus doutorados em cinco anos ou mais e, muitas vezes, já atuando como professores, paulatinamente tiveram que passar a orientar seus alunos em prazos mais curtos, adequando-se também às normas das agências financiadoras.

Ao constatar mudanças na construção das carreiras acadêmicas na Faculdade de Filosofia, Sérgio Adorno considerou necessário realizar uma avaliação ponderada que permita compreender as razões que levaram as novas gerações a terem um comportamento acadêmico e intelectual mais dinâmico e precoce: 
Nesse ínterim fiz a minha livre-docência que foi concluída em 1996 e, depois, me tornei titular em 2004. Aqui tem um dado importante para ser avaliado. Na minha época, essas etapas da carreira ainda eram pensadas como um momento de muita maturidade. Veja, o meu doutorado foi em 1984, a livre-docência foi defendida doze anos depois e o concurso de titular oito anos mais tarde. Então venho de uma geração em que a pessoa se aventurava aos concursos quando se estava convencido de que tinha uma obra publicada, ou seja, trabalhos de referência que podiam ser julgados pelos seus pares. Isso só acontecia quando o professor já tinha formado alunos, dado cursos e participado de alguma gestão... Então era uma carreira pensada do ponto de vista intelectual e acadêmico. Hoje acho que isso mudou, que essas coisas são diferentes. Não vou aqui fazer um julgamento de valores, se para o bem ou para o mal. Mas mudaram e acho que isso é um dado que precisa ser avaliado. Se você olhar como funcionava no passado, observará que na minha geração ocorreram coisas diferentes e isso continua mudando. Não se trata aqui de julgar ninguém, muito pelo contrário. Mas isso significa mostrar que as coisas estão mudando e está havendo uma pressão pela competição. Pressão para se fazer carreiras mais rápidas e por maior autonomia. Em termos de maturidade isso tem seus reflexos... Quer dizer, é muito difícil ter pessoas tituladas muito cedo que chegam com a maturidade necessária. Agora, isso pode ser bom por outro lado, não é? Porque muitas carreiras também deixaram de ser feitas porque as pessoas ficavam em uma eterna autocrítica e acabaram não fazendo nem a livre-docência, nem o concurso para titular. E isso é uma pena.

As considerações de Adorno revelaram as inquietações de toda uma comunidade docente em relação aos destinos da profissionalização da carreira acadêmica. Constatase, assim, que para as gerações que compõem a comunidade acadêmica estudada, a progressão na carreira docente era concebida como consequência de um processo de amadurecimento intelectual individual, mas que deveria fazer justiça a um conjunto de trabalhos elaborados coletivamente.

Uma das formas encontradas pelos docentes para respeitar o processo de gestação do trabalho intelectual de cada professor e garantir a progressão coletiva do grupo na carreira foi explicitada por Mário Miguel González. Ele destacou que o início dos trabalhos de pós-graduação em Espanhol que começaram em 1978, foram coroados com o credenciamento do mestrado e do doutorado pela CAPES em 1985. Segundo o professor, foram os relatórios enviados periodicamente à essa instituição que levaram a mesma a enviar uma comissão de professores da Universidade Federal do Rio de Janeiro (UFRJ), o que permitiu o desenvolvimento das pesquisas em nível de pósgraduação e a evolução acadêmica dos docentes: 
Esse grupo trabalhou durante 25 anos junto, todos os quatro, até que eu me aposentei. Nós nos unimos em 1982 e até 2007 trabalhamos juntos. Era uma equipe fantástica, tanto pelo trabalho quanto pelas relações pessoais que eram muito boas. Fomos nós que inventamos o chamado semestre que mais tarde seria chamado de sabático. Como funcionava isso? Se éramos quatro e tínhamos vinte e quatro semanas de aula, por que, ao invés de dividirmos em quatro, não dividirmos em três? Se cada um desse oito horas de aulas, o outro teria condições de ficar livre para fazer pesquisa. Nós fizemos isso durante anos. E não era algo matemático, funcionava quando alguém dizia que precisava. Então não havia cobranças porque não havia uma escala definida, funcionava quando era conveniente para o professor. Isso ajudou muitíssimo a nossa carreira porque nós tínhamos um semestre livre, na prática, a cada dois anos, somente para pesquisa. Tanto isso funcionou que a Valéria é professora titular, eu cheguei a titular, a María de la Concepción chegou a titular e a Maria Augusta é livre docente e chefe de departamento de Letras Modernas. Certamente, quando houver vaga, ela chegará à professora titular também. Eu posso dizer que se eu pudesse escolher o que fazer novamente, digo que seria trabalhar novamente com essas pessoas. Foi muito, muito bom.

A coesão do trabalho empreendido por esse grupo de professores pertencente ao Departamento de Letras Modernas evidencia a existência de formas cotidianas de resistência e controle do processo de profissionalização acadêmica no interior da comunidade docente. Além disso, demonstra uma compreensão da carreira acadêmica enquanto parte de um projeto coletivo e de amadurecimento intelectual que interessava à Faculdade de Filosofia como um todo. Por isso, na interpretação de Adorno, atualmente a "pressão para se fazer carreiras mais rápidas" corrompe a essência de um projeto coletivo que era capaz de mediar o avanço puro e simples de cada professor em sua trilha acadêmica exclusiva.

Muitos professores relataram suas inquietações em relação ao futuro das carreiras acadêmicas. Para Theodoro da Silva, os novos prazos e o domínio das normas estabelecidas pelas agências de fomento à pesquisa tem contribuído para a construção de uma nova realidade institucional. Ainda segundo a professora, essas modificações prejudicam o trabalho docente e dificultam o estabelecimento de um diálogo profícuo entre a pesquisa acadêmica e os problemas políticos e sociais que acometem a sociedade brasileira:

A grande transformação na universidade brasileira foi ditada pelas agências financiadoras. Antes você tinha um determinado projeto político que levava a frente na universidade. Fazia-se uma tese e 
pensava-se que, de alguma forma, o trabalho poderia repercutir politicamente. A pesquisa deveria oferecer alguma informação para se conhecer melhor a realidade e, em última instância, poder transformála. Tanto é que podem ser vistos muitos estudos sobre o movimento operário nesta época. Basta pegar os alunos do Francisco Weffort ${ }^{131}$ na Ciência Política. Pensar que o Régis Stephan de Castro Andrade, que era irmão do meu primeiro marido e foi líder na greve de Osasco... Eles desenvolveram estudos específicos cujo objetivo era transformar a realidade.

Theodoro da Silva relatou também que ficou cada vez mais difícil desenvolver pesquisas que ousam desafiar os padrões dominantes de interpretação. Segundo a professora, em primeiro lugar, isso se deve ao fato das novas gerações dependerem cada vez mais das bolsas concedidas pelas agências financiadoras e estarem sujeitas aos limites por elas impostos e, em segundo lugar, à escassez de projetos de pesquisa compromissados com propostas críticas e utópicas:

Voltando a questão dos financiamentos. Eles acentuaram o fim dos projetos críticos e das utopias. Veja só, um aluno pede uma bolsa de pesquisa. O projeto vai para um assessor que tem predileções bibliográficas. $\mathrm{O}$ aluno, por sua vez, tem que evitar desagradar. Caso ele caia com um assessor que não concorde com o seu trabalho ele corre o risco de perder a bolsa. Como ele vai ficar sem a bolsa e sem o dinheiro para sustentar sua família? Então, na verdade, o que os financiamentos e as bolsas de pesquisa fizeram? Criaram um discurso com algumas tendências predominantes! É mais garantido desenvolver um trabalho que se aproxima do discurso dominante, similar àqueles de quem tem poder acadêmico. Existem orientadores que tem força política e garantem a sobrevivência da sua pesquisa e outros com menos força político-acadêmica. $\mathrm{O}$ mais seguro é evitar o confronto direto com o pensamento dominante. $\mathrm{O}$ mais seguro é repetir as sonoridades dominantes para garantir a bolsa, a tese, o emprego. Mas esse modelo não estimula o pensamento crítico. Não dá para você criar um pensamento crítico se você sabe que poderá perder a bolsa e o futuro emprego caso discorde do pensamento dominante.

A avaliação crítica de Janice procurou delimitar uma fronteira entre as gerações anteriores, que dão conformidade à comunidade docente estudada, e aquelas que assumiram a docência depois da consolidação da profissionalização acadêmica nos anos 1980. A sua narrativa chama atenção para o perigo de que a Faculdade de Filosofia

\footnotetext{
${ }^{131}$ Francisco Weffort (1937- ) é professor aposentado da USP. Doutorou-se em Ciência Política pela USP com a tese Populismo e Classes Sociais e defendeu sua livre docência com a tese Sindicatos e Política.
} 
perca a capacidade de resistir às pressões e obstáculos implantados pela lógica do "publish or perish". Foi nesse sentido que alguns professores pertencentes à comunidade docente descreveram o cenário recente da Faculdade de Filosofia, temendo que "os docentes mais jovens já tenham se adequado à nova realidade" por conta de estarem inseridos em programas de formação que privilegiaram a especialização e a produção acadêmica de maneira precoce. O que importa obervar nessas avaliações, certamente precipitadas em relação às novas gerações, é o modo como os docentes diferenciam a sua trajetória acadêmica daquelas que começaram a ser traçadas a partir da consolidação da profissionalização das carreiras universitárias.

Dentre as características assumidas pelas pesquisas durante o avanço da institucionalização acadêmica que causaram apreensão na comunidade docente, foi citado o predomínio dos critérios estabelecidos pelas agências financiadoras. Durante a entrevista concedida, Nitrini apresentou um parecer condenando certas práticas adotadas pelas empresas de fomento. Além disso, sua narrativa permitiu avaliar as diferenças entre a construção das carreiras acadêmicas até a aprovação do Estatuto da USP em 1988 e posteriormente:

Hoje digo que essa lógica produtivista já está introjetada porque as novas gerações dos nossos docentes já cresceram e se desenvolveram dentro dessa mentalidade. Você quer ver uma coisa? Quando recebo parecer da FAPESP, vejo que este órgão atualmente leva em consideração muitos elementos quantitativos na avaliação docente. A FAPESP era diferenciada em relação aos outros órgãos de fomento. E hoje quando recebo pareceres relativos a trabalhos de alunos, bem como pedidos para a publicação de seus livros, percebo como a mentalidade dos pareceristas dessa instituição de fomento é extremamente produtivista. Como querer que um recém-doutor, uma pessoa que acabou de se formar, de defender seu doutorado e até mesmo um doutorando tenha uma lista de publicações imensa? Por que defender isso? A manifestação do parecerista: "O candidato não tem publicação". No corpo do parecer elogiam o trabalho, mas... E a verdade é que isso está disseminado, hoje em dia não é novidade. Em geral, os docentes mais antigos questionam este tipo de parecer, mas para as gerações mais novas isso é normal. Sem cair nas falácias das generalizações, uma boa parte dos docentes que se formaram neste clima tem pouco envolvimento com o ensino da graduação. É a geração que realizou mestrado com bolsa e doutorado com bolsa, em seguida, pós-doutoramento com bolsa, toda uma formação dedicada exclusivamente à pesquisa. Quando ingressam no magistério superior, priorizam congressos, viagens, pesquisas por longo período no exterior. Não se trata de minimizar a dedicação à pesquisa com esta observação, mas tão somente assinalar o que tem ocorrido com relativa frequência. Para evitar qualquer mal-entendido quanto às 
minhas afirmações, reafirmo a necessidade absoluta da dedicação à pesquisa, como também à docência. O Prof. Gabriel Cohn tem razão quando diz que antes nós sentíamos que devíamos nossa formação à Faculdade, à Universidade. Hoje o reconhecimento é com as agências de fomento. Houve uma mudança. Você tem aí os dados objetivos, que influem na formação da mentalidade.

Para Nitrini, o fato dos professores pertencentes a sua geração terem iniciado as atividades docentes como graduados ou mestres, permitiu o estabelecimento de uma relação de proximidade e compromisso com a docência na graduação, tomando-a como parte integrante da construção das carreiras acadêmicas. A avaliação da professora justifica-se pela condição privilegiada de quem vivenciou todo o processo de estruturação e profissionalização docente até o seu derradeiro estágio que, segundo ela, se caracteriza pelo aumento da dependência destes em relação a uma formação presa à pesquisa e às agências financiadoras em primeira instância.

Apesar das constantes referências em relação às novas gerações de professores, a comunidade docente parece acreditar na capacidade da Faculdade de Filosofia resistir às pressões externas e preservar a sua autonomia. As considerações de Francisco de Oliveira a respeito do ambiente de trabalho que vivenciou no Departamento de Sociologia endossam o potencial de alunos e professores na defesa de um projeto político e pedagógico que privilegia o desenvolvimento de pesquisas originais e independentes:

Eu nunca tive que dar satisfação nenhuma da matéria que eu estou dando em sala de aula. Então a FFLCH é um lugar onde o professor pode exercer as suas atividades e não tem a concorrência produtivista. Não existe pressão para publicar. Essa pressão para publicar é da CAPES, do CNPq e, de certa forma, do ambiente internacional. Existe essa influência que vem do estilo norte-americano de publicar, publicar, publicar. Na FFLCH essa pressão não existe. E espero que ela nunca adote esse modelo de faculdade porque isso não conduz a nada. Há alguns anos atrás, o José Goldemberg levou essa discussão para a Folha de São Paulo. O Goldemberg foi talvez um dos bons reitores que a USP teve nas últimas décadas... Bom, sei que a Folha então iniciou uma série de publicações sobre trabalho produtivo de docentes, mas essa é uma avaliação equivocada. O Celso Furtado que nunca esteve em nenhuma universidade brasileira, ou seja, percebe-se que as universidades eram pouco abertas a intelectuais como Celso Furtado. Ele pode ter dado cursos na PUC, mas na USP não. Há também o Caio Prado, grande historiador que também nunca foi da universidade. Quando houve esta discussão, o Celso Furtado que sempre é muito discreto, interviu e escreveu um artigo sobre o que é ser produtivo ou não como intelectual na universidade. Ele citou o 
exemplo de Piero Sraffa, que foi um economista italiano e devido ao fascismo migrou para a Inglaterra e escreveu um único livro. O livro se chama: Produção de mercadorias, por mercadorias. E ele editou toda a correspondência de David Ricardo. Dizia então o Celso Furtado: "Pelos critérios da Folha de São Paulo, Piero Sraffa seria improdutivo". Felizmente isso não colocou dentro das áreas de humanas, mas em outras áreas isso pegou. Aliás, em algumas áreas existem artigos com cinquenta assinaturas... Ora, isso não existe! Isso funciona só para mostrar no currículo Lattes uma tonelada de coisas... Também não é possível dizer que esse produtivismo, essa concorrência nas áreas de humanas não exista de nenhuma maneira. Não sejamos extremistas, mas o que acontece não chega a ser obsessivo e nem atrapalha as atividades daqueles que não querem entrar nessa correria.

Para a memória coletiva da comunidade docente, a publicação da chamada "lista dos improdutivos" inaugurou de maneira perversa o debate em torno da avaliação docente na USP. Para alguns docentes, o procedimento atendia a interesses externos à universidade, pretendia desqualificar o setor público e questionar os recursos empregados em educação para justificar modificações em sua gestão. Para outros, não teve o objetivo de colocar questões relativas à produção do conhecimento para serem discutidas e implementadas com a participação dos professores das diferentes áreas do conhecimento. Na época, ao tentar de forma estabanada taxar alguns professores como "improdutivos", a publicação da lista criou na verdade um neologismo que jamais sairia do espectro universitário brasileiro e assombraria as práticas avaliativas formuladas desde então: o produtivismo.

Quando perguntados a respeito da sua percepção em relação ao produtivismo acadêmico, a maior parte dos docentes preferiu questionar os limites da concepção avaliativa presente na lista publicada em 1986, propondo a superação deste paradigma. Nas entrevistas, os professores enfatizaram a necessidade de pensar a avaliação docente como um tema necessário e essencial para a universidade pública. Estando entre aqueles que destacaram mais enfaticamente a importância da avaliação, Janine Ribeiro explanou, entre outras coisas, sobre a necessidade de se superar as barreiras que foram criadas diante da avaliação docente e universitária:

O que significa produtivismo? Ouço muito falar, mas nunca vi. Não existe corrida pelo currículo Lattes. Este é um currículo que você tem que interpretar e avaliar. O que você coloca no currículo é uma coisa... Bom, outro dia vi um debate totalmente alucinado de gente perguntando onde era possível lançar uma participação como suplente 
de banca. Bom, a conclusão era de que seria possível lançar no tópico "outras produções". Se eu receber um Lattes no qual alguém incluiu o fato de ter sido "suplente de banca" para dar o parecer, darei um parecer negativo. Porque, se alguém chegou ao ponto de colocar isso, é porque não tinha nada para colocar. Então veja, o Lattes é só um instrumento, o que importa é qual avaliação vai ser feita com ele e com outros elementos. Já o produtivismo é, sobretudo, um mito. Afinal, o Qualis da CAPES impede que isso ocorra. Um pesquisador pode ter trinta artigos e eles não valerem nada de acordo com o Qualis. Agora, isso não quer dizer que a produção não coloque problemas que precisam ser discutidos a sério.

Para Janine Ribeiro todos os esforços empreendidos pela CAPES na regulamentação e na prática avaliativa da pós-graduação no Brasil foram imprescindíveis. O crescimento do número de programas de mestrado e doutorado, bem como do número de professores universitários desde a década de 1970, levou a necessidade do Estado criar sistemas avaliativos capazes de estabelecer critérios que pudessem nortear contratações e investimentos. O professor acrescentou ainda, que os processos avaliativos fazem parte de princípios democráticos que tem como intuito defender a boa gestão dos recursos públicos e não a introdução da lógica empresarial na universidade:

\begin{abstract}
A prestação de contas na nossa área é também, muitas vezes, vista com restrição. Um número não trivial de professores de humanas acha que é uma intromissão indevida ser chamado a prestar contas. Isso é muito esquisito, porque são justamente eles que deveriam mais conhecer o que é a sociedade, só que em vez de assumirem um claro compromisso social preferem identificar sociedade a empresa, e entender que prestação de contas é de uma lógica empresarial, e não política e democrática. Choca-me essa comédia de mal-entendidos. Até porque não estou dando razão aos colegas das exatas e biológicas: a visão que eles mesmos têm da sociedade é, com frequência, reducionista. O mérito grande das Humanas está em mostrar que assuntos sobre os quais cada um discorre, os assuntos cidadãos, são mais complexos do que o cidadão pensa.
\end{abstract}

A despeito de sua resistência em participar de atividades político-partidárias, Janine Ribeiro desenvolveu ao longo da sua carreira uma importante atividade na política científica e universitária e, inclusive, atuou em agências de pesquisa no âmbito federal. Participou do Conselho Deliberativo do CNPq (1993-1997), da Sociedade Brasileira para o Progresso da Ciência (1997-2003) e, anos mais tarde, esteve à frente da Diretoria de Avaliação da CAPES entre 2004 e 2008, quando trabalhou diretamente no 
aperfeiçoamento de processos avaliativos coordenados por essa agência. Durante a entrevista concedida, Janine fez questão de explicitar os esforços que foram empreendidos nas últimas décadas no sentido de estabelecer critérios rigorosos de avaliação:

Ao ser convidado para ser diretor da Capes, coloquei duas condições, a primeira era acabar com o tempo médio de titulação, um critério que penalizava os cursos que demorassem a formar mestres e doutores. A segunda era considerar o livro como produção científica relevante. A questão é que, para o livro ser uma produção científica relevante, ele tem que ser avaliado. Aí surgiu o problema. Alguns se dispuseram a fazê-lo, como os geógrafos. Vale destacar o magnífico trabalho feito pelo Prof. Dr. Ariovaldo Umbelino de Oliveira, do Departamento de Geografia da USP. Ele mandou cada um dos livros de geografia que saiu no triênio que estava sendo avaliado, com um questionário, para três pareceristas. A partir dos pareceres, construiu uma tabela graça à qual se podia avaliar a área levando em conta a produção de Geografia como um todo e suas especificidades, como a física e a humana. Mas também falei com a Antropologia, em 2004.

Moisés questionou o fato da administração do reitor Goldemberg ter sido interpretada como favorável a adoção de princípios produtivistas na avaliação da universidade. Durante a entrevista concedida, Moisés apresentou argumentos favoráveis à necessidade de se avaliar o trabalho docente levando em conta o respeito em relação aos problemas e desafios impostos pela sociedade. Nesse sentido, defendeu que a autonomia desfrutada pela universidade deve levar em conta processos avaliativos para que os investimentos públicos possam ser utilizados com responsabilidade social:

O simples fato das pessoas fazerem concursos e carreira, não é suficiente para saber se estão produzindo. Produzindo em relação a que? É preciso saber se estão produzindo em relação ao objetivo central da ciência que é o de vincular o pensamento e a atividade intelectual, os métodos de pesquisa, com os desafios apresentados pela sociedade. Isso não é automático, ou seja, só porque os professores passaram por um concurso, fizeram livre-docência e atingiram a titularidade, que os pesquisadores estão prontos. Não, essa é uma tarefa que tem que ser articulada, precisa ser proposta. Essas tarefas devem ser parte de um programa científico mais articulado. E para que isso aconteça, a avaliação é um mecanismo que existe para saber se os programas estão sendo cumpridos. Então acho que a primeira grande inovação que ocorreu em relação ao imobilismo que ocorria na universidade no que diz respeito a esses temas, foi essa proposta pela administração do Goldemberg. Isso acarretou várias consequências. Algumas negativas quando se interpretou que isso se tratava de uma exigência favorável ao produtivismo, o que não foi o caso. Mas houve 
também reações promovidas por departamentos, institutos e organismos centrais, no sentido de verificar qual estava sendo a conduta e o desempenho dos pesquisadores e dos professores. Além disso, a universidade foi progressivamente introduzindo mecanismos de avaliação. Hoje, até os cursos de graduação são avaliados pelos próprios professores e pelos alunos.

Moisés não abordou especificamente o episódio da "lista dos improdutivos" para enfatizar a implantação da avaliação do trabalho acadêmico durante a administração de José Goldemberg na reitoria da USP. Contrário ao chamado produtivismo, Moisés acredita que o estabelecimento de critérios capazes de ajuizar o trabalho intelectual passou a desempenhar um papel importante e indispensável na gestão da vida universitária.

Entre os professores que pertencem à comunidade docente, Durham está entre aqueles com mais experiência nas atividades ligadas à administração das políticas científicas, tendo participado da idealização e implantação de boa parte dos parâmetros para avaliação do ensino superior e da pós-graduação no país a partir dos anos 1990. Quando atuou como assessora para política universitária durante a administração Goldemberg, sugeriu a criação de um núcleo de pesquisas que pudesse auxiliar as reitorias das três universidades estaduais de São Paulo. Sua proposta resultou na criação do Núcleo de Estudos e Pesquisas sobre o Ensino Superior (NUPES) ligado diretamente à reitoria da USP, já que as outras instituições não haviam se interessado pela proposta. Desde então, contando com a participação de Simon Schwarztman, esse núcleo passou a desempenhar um papel muito significativo na reunião e organização de propostas que influenciariam o planejamento do ensino superior em nível nacional ${ }^{132}$.

Em entrevista, Durham explanou sobre a necessidade de superação do modelo universitário vigente e defendeu a formulação de um plano de gestão para o ensino superior que valorize a profissionalização das atividades e a conquista de resultados economicamente mensuráveis para a sociedade. Uma das principais teses elaboradas por Durham a partir de suas pesquisas, afirma que o Brasil gasta mais que a maioria dos países da América do Sul e alguns Tigres Asiáticos em educação pública e que mais de

\footnotetext{
${ }^{132}$ BARREYRO e ROTHEN avaliaram detalhadamente a influência do Nupes na educação superior brasileira, demonstrando a sua relevância - não como criador de propostas -, mas como "catalisador de pesquisas e ações no sentido de influir nas políticas públicas para a educação superior": BARREYRO, G. B. \& ROTHEN, J. C. "O Nupes e a avaliação da educação superior: concepções, propostas e posicionamentos públicos". In: CATANI, A. M. \& SILVA JÚNIOR., J. R. \& MENEGHEL, S.M.. (Org.). A cultura da universidade pública brasileira. São Paulo: Xamã, 2011, p. 129-147.
} 
75\% desses recursos são destinados para o ensino superior, o que significa que o problema esta não em aumentar os investimentos, mas em garantir uma gestão adequada dos recursos. Em segundo lugar, destaca que a principal demanda social no Brasil é por ensino superior e não por instituições que associam ensino à pesquisa. Partindo dessas questões, a professora defendeu a diferenciação dessas perspectivas e a formulação de modelos avaliativos capazes de cobrar tanto os investimentos destinados às universidades quanto aqueles conferidos ao ensino superior ${ }^{133}$.

Em atitude sempre provocadora, Durham apresentou uma concepção de gestão que cobra da universidade pública uma maior relação com o setor produtivo, reivindica uma melhor administração dos recursos públicos em pesquisa e argumenta que falta estabelecer critérios que sejam capazes de cobrar mais resultados das instituições universitárias e que possam guiar o Estado na alocação e aplicação das verbas:

\begin{abstract}
A instituição passa a receber de acordo com o que faz: aumenta isso e terá isso. Isso se chama accountability. Necessário para a universidade. Mas nós não temos isso aqui no Brasil. As três universidades paulistas têm uma enorme vantagem de serem autônomas porque as federais não são. Mas não existe essa questão da accountability. Porque só existe a verba vinculada, não existe o outro processo da distribuição de verba de acordo com indicadores de eficiência e produtividade... E de atenção às necessidades da população.
\end{abstract}

As teses defendidas por Durham e pelo NUPES foram inspiradas em pesquisas e trabalhos publicados nos Estados Unidos e em toda América Latina, tendo como principais referências o próprio Simon Schartzman, cofundador do núcleo, e José Joaquim Brunner que é professor universitário no Chile e chegou a presidir a Comissão Nacional de Avaliação de universidades em seu país. É preciso frisar que as pesquisas e ações propostas por Durham e pelo NUPES, contaram com ampla repercussão, foram sistematizadas e transformaram-se em políticas públicas porque, em alguns momentos, estiveram em plena sintonia com as decisões defendidas pelo governo Fernando Henrique Cardoso. Alguns autores denominaram essa perspectiva adotada em relação à gestão da educação pública e à avaliação da universidade de neoliberal e observaram

\footnotetext{
${ }^{133}$ DURHAM, E. R. "Uma Política para o Ensino Superior: Diagnóstico e proposta". Documentos de Trabalho NUPES, São Paulo, v. 1, p. 66. Ver: http://nupps.usp.br/downloads/docs/dt9801.pdf. Página consultada em 14/04/2014.
} 
que essas políticas educacionais cercearam os investimentos governamentais entre os anos 1980, 1990, 2000, senão, depois de implantadas, até os dias atuais ${ }^{134}$.

Abdala Jr. foi presidente da Associação Brasileira de Literatura Comparada e atuou junto ao $\mathrm{CNPq}$ em duas oportunidades e também coordenou a área de Letras e Linguística da CAPES. Sua experiência atuando como assessor científico na esfera federal possibilitou o desenvolvimento de uma proposta de ajuizamento das atividades acadêmicas que defende a diferenciação dos critérios de avaliação de acordo com o campo do conhecimento; respeitando as especificidades pertencentes às humanidades:

\begin{abstract}
A questão do produtivismo precisa ser compreendida nesse contexto. Pense nas áreas de pesquisa basicamente dependentes dos laboratórios. Todos que participam do laboratório assinam muitas vezes um artigo que tem uma página, duas páginas. Como que posso querer comparar esse artigo com um texto de reflexão que vem das áreas de humanas? Esses artigos são publicados em revistas estrangeiras. Já os nossos artigos devem ir para as melhores revistas que são as nacionais, como aquelas na área de História e Literatura. Em nossas áreas as principais revistas não são as estrangeiras. Então a avaliação não pode adotar um procedimento similar. É preciso buscar critérios de avaliação que sejam inerentes à própria área. Isso pressupõe leitura. Além disso, as nossas melhores produções nas áreas de humanas são organizadas em livros. Para escrever um bom livro, um indivíduo pode demorar 30 anos, então a nossa avaliação tem que ser uma avaliação muito mais fina, muito mais qualitativa e não meramente quantitativa.
\end{abstract}

Uma das principais ênfases presentes na memória coletiva da comunidade docente diz respeito à necessidade dos procedimentos avaliativos respeitarem as características que são específicas a cada área do conhecimento. A condenação de práticas quantitativistas foi uma questão muito recorrente nas narrativas docentes, como se pode observar em outro trecho da entrevista de Abdala Jr.:

Considero necessária a avaliação. A sociedade contemporânea pede uma intervenção pública do intelectual, do professor universitário e, também, uma interação com a sociedade. Como digo sempre, nós dialogamos publicamente. Esse diálogo primeiro pode ser publicado como uma comunicação, mas, depois, posso combiná-la com outras

\footnotetext{
${ }^{134}$ GENTILI, P. \& SILVA, T. T. (org). Escola SA. Brasília: CNTE, 1994; GENTILI, P. \& SILVA, T. T. (org). Neoliberalismo, qualidade total e educação. Petrópolis: Vozes, 1995; FRIGOTTO, G. A produtividade da escola improdutiva. São Paulo: Cortez, 1993; FRIGOTTO, G. Educação e a crise do capitalismo real. São Paulo: Cortez, 2000; MÉSZÁROS, I. A educação para além do Capital. São Paulo: Boitempo, 2005. Irene Cardoso também desenvolveu uma crítica ao modelo de avaliação proposto pelos intelectuais citados à universidade. Ver: CARDOSO, I. Para uma crítica do presente. Op. cit..
} 
comunicações, vamos dizer assim, e fazer um texto de maior profundidade. Enfim, é preciso buscar critérios qualitativos. O produtivismo no sentido estrito é uma coisa, produtividade é outra. Quer dizer, pensando a questão da produtividade, é importante pensar que o professor pode se expressar através de vários meios que devem ser considerados. Às vezes ele demora um tempão para escrever um livro, mas aquele livro é um livro influente. É diferente da pesquisa nas outras áreas, quando o indivíduo fica lá no laboratório com o grupo todo, descobre que em tal partícula ocorre isso ou aquilo e é feita uma descrição na qual a análise é mínima. Bom, o nosso texto consiste somente em análises, então nós teríamos que ter também mesmo para as revistas -, critérios totalmente diferentes.

Leopoldo e Silva também defendeu o estabelecimento de critérios e parâmetros avaliativos que contemplem as especificidades das áreas de humanidades quanto ao tempo de formação dos discentes enquanto professores e pesquisadores:

Há certas concepções políticas, crenças e suposições, no entanto, que atuam em todas as instâncias, na FAPESP, no CNPq e até na CAPES. Uma delas, que nos afeta bastante particularmente na Faculdade de Filosofia, é a questão dos prazos. Isso para nós é muito problemático porque envolve não só uma questão quantitativa, mas uma distorção do trabalho intelectual. Talvez haja trabalhos científicos como coleta de dados e seleção dos mesmos, em que a questão quantitativa possa ser controlada. No caso das humanidades, especificamente da Filosofia, é muito difícil, ou seja, todo o perfil do trabalho é afetado. Nós estamos tendo essa experiência com os mestrados de dois anos e os doutorados de quatro anos. Nós temos tido a experiência de notar que há uma dinâmica do trabalho intelectual e da própria conduta da pessoa enquanto pesquisador. Os prazos incidem sobre isso. E não é a questão de você ter 2,3 ou 4 anos... Mas quando você tem isso predeterminado, o perfil qualitativo da própria pesquisa está predeterminado. Desde a própria escolha, desde a opção pelo assunto feita pelo pesquisador.

A preocupação levantada por Leopoldo e Silva, em relação à especialização precoce dos pesquisadores, denota a presença de certos compromissos assumidos pela comunidade docente quanto a uma formação humanista que valorizava a presença dos conteúdos clássicos e o desenvolvimento autônomo do aluno. Os choques decorrentes da redução dos prazos impostos à realização das pesquisas em nível de graduação e pósgraduação explicitam as diferenças entre as experiências acadêmicas dos docentes e aquelas vivenciadas por seus orientandos.

As contradições existentes entre a formação propiciada à comunidade docente e as condições de trabalho impostas pela profissionalização da carreira e institucionalização 
da pós-graduação, segundo alguns relatos, se intensificaram a medida que os professores passaram a ser submetidos a um número cada vez maior de tarefas que tornaram a docência e a pesquisa atividades secundárias.

Quanto ao ambiente acadêmico, Alessandri Carlos veio a público demonstrar recentemente seu descontentamento em relação ao acúmulo de responsabilidades burocráticas através da publicação de um manifesto contra o produtivismo:

Recentemente, em 2012, publiquei um manifesto intitulado "Contra o produtivismo: um protesto solitário", onde defendi que o papel da universidade é o de ensinar formando cidadãos e aponto como essa tarefa tem sido prejudicada pela espera cada vez maior de simples resultados quantitativos, ou seja, de muitos papers publicados. Mas, ninguém se pergunta ou questiona seus conteúdos ${ }^{135}$.

Para Alessandri Carlos o acúmulo de demandas sobre os docentes tem sido incompatível com a diminuição dos prazos e gerando um impacto negativo na produção universitária uspiana e contribuindo para o esvaziamento da vida acadêmica. As principais consequências do produtivismo para a professora foram, em primeiro lugar, o afastamento dos docentes do compromisso com o ensino e uma formação de qualidade e, em segundo lugar, a desatenção aos problemas e necessidades da comunidade:

Na Faculdade de Filosofia só é possível produzir com qualidade se o sujeito habitar o tempo. Tempo este que é o da reflexão, da leitura. Hoje em dia quem pode ir à biblioteca? Nós estamos imersos na burocracia. Hoje, por exemplo, estou desde 7 h30 da manhã preenchendo papel. Compro um livro e ele fica em cima da mesa porque tenho que preencher um monte de relatório, pareceres... Se a CAPES quer uma coisa nesse instante, então você tem que apresentar. Agora, mais uma coisa, querem que você entre no Qualis, mas não se consegue acesso ao site que eles mandam acessar! Então você perde um tempo monumental da sua vida atrás da burocracia e, todo esse tempo, é subtraído das suas leituras, da sua reflexão e da formação dos alunos.

A USP perdeu muito dos anos 1980 para agora. E ela perdeu concretamente na medida em que o professor passou a entrar como doutor. O doutor tem que ir para a pós-graduação e, esta passa a ser na prática, o mais importante em sua vida cotidiana. A graduação está deixada de lado. O produtivismo obriga o professor a escrever e a participar de um monte de congressos. Nestes se fala sempre a mesma coisa, cada vez mais destituídos de grandes conteúdos, porque na

\footnotetext{
${ }^{135}$ O manifesto escrito por Alessandri Carlos "Contra o produtivismo: um protesto solitário" pode ser lido na íntegra em http://www.cadernoterritorial.com/news/contra-o-produtivismo-um-protesto-solitario-anafani-alessandri-carlos/
} 
medida em que todo mundo tem que produzir cada vez mais, a burocracia aumenta cada vez mais, então os congressos estão menos densos, as questões menos importantes. E a USP trilhou esse caminho, mas acho que ela podia ter trilhado e seguido uma via mais inteligente, que é o caminho da qualidade, da formação, do compromisso com a nossa sociedade. Cada vez mais a USP tem um compromisso com o mercado, cada vez mais preocupada com a internacionalização e com as relações de mercado. Consequentemente, a USP está muito menos preocupada com um trabalho consequente, no qual as pessoas possam ter tempo para a reflexão, um trabalho aonde a burocracia se resolve por ela mesma e não fique tomando um tempo brutal. Há um exacerbado individualismo que não havia nos anos 1980.

O manifesto escrito por Alessandri Carlos explicitou a posição de uma parcela dos docentes contrários ao avanço de práticas avaliativas quantitativistas e reivindicou outras formas de cumprir com os compromissos acadêmicos propondo a retomada de modelos anteriores aos anos 1980. Em geral, as reivindicações presentes no texto representam manifestações comuns à memória coletiva de uma comunidade docente espremida entre parâmetros de produção e formação acadêmica anteriores e posteriores ao processo de profissionalização da carreira universitária.

Sandra Vasconcelos também destacou o aumento das demandas burocráticas sobre os professores para além das atividades de ensino, pesquisa e extensão, o que acabou comprometendo o cotidiano docente e prejudicando a produção de pesquisas:

Portanto, sou a favor da democratização e do acesso ao ensino superior, por outro lado existe uma massificação e um cotidiano que acabam, na verdade, te engolindo. Eu trabalho muito mais hoje do que na época em que iniciei. Hoje as demandas vêm de toda parte. Além de atender as responsabilidades que tenho na USP, sou parecerista do CNPq, da CAPES, da Fundação de Amparo à Pesquisa do Estado de São Paulo (FAPESP) e, às vezes, de alguma outra agência de fomento de outros estados. Esse é um tipo de demanda que chega meio que sem avisar. Chega coisa nova de forma inesperada às vezes naquela semana que você está mais atolado de coisa. Além disso, quando o professor se torna parecerista de revistas, elas ficam mandando coisas. Chegou um ponto em que eu comecei a falar não. Não, não, não. Passei a cortar um pouco os convites, se não fica absolutamente impossível! É uma lógica que se reproduz. Afinal, o próprio reprodutivismo cria esse tipo de coisa. Quanto mais as pessoas publicam, mais existe a necessidade de parecerista, mais revistas surgem. Mais, mais, mais! Então chega. Pára! Não dá.

As preocupações de Vasconcelos expressam a relação conflituosa de toda uma comunidade docente corresponsável pela institucionalização da carreira acadêmica e, ao 
mesmo tempo, pressionada a conservar as condições de trabalho e a qualidade da produção acadêmica anterior à profissionalização e ao aumento de todo os tipos de demandas decorrentes desse processo.

Sérgio Adorno desenvolveu ao longo de sua narrativa uma reflexão a respeito do impacto da profissionalização da carreira acadêmica entre os docentes pertencentes à sua geração. Segundo sua análise, a comunidade docente a que pertence pagou um alto preço diante da necessidade de estabelecer uma avaliação adequada e coerente da produção acadêmica, atendendo as especificidades de cada área do conhecimento e evitando o produtivismo:

Acho que vale a pena refletir sobre essas exigências porque a minha geração está pagando um custo em relação a isso. Qual é esse custo? O de tentar manter a tradição dos estudos intelectuais de intensidade e, ao mesmo tempo, ter que responder às demandas da sociedade pelo aumento da produção e ao consultor institucional. Eu tenho que gerir um grupo de pesquisa. Tenho que estar lá na CAPES para fazer avaliação dos programas de pós-graduação, tenho que estar em uma comissão aqui da universidade... Essa é uma geração, diria, muito sacrificada. Quando a geração nova chega, ela já encontra esse campo institucional formado. Então ela desenvolve suas pesquisas em um campo diferenciado. Embora saiba que já tem muitos jovens sacrificados na universidade, ainda acho que a minha geração foi mais pesadamente atingida. Eu, por exemplo, nunca consegui reunir todos esses estudos que fiz em um livro próprio. Estou sempre prometendo um livro, mas não fiz. E não fiz porque quero fazer uma coisa nova $\mathrm{e}$ não apenas juntar as coisas. Enfim, como disse, isso é um fato, mas que precisa ser muito discutido e administrado de uma maneira que se possa responder a essa demanda de regularidade no trabalho acadêmico e da densidade, sem afetar a qualidade. Mas, ao mesmo tempo, não se pode dizer: "Olha, pelos próximos dez anos estarei sentado esperando as ideias virem". Isso não é possível. Não dá mais para fazer isso.

As considerações de Adorno sintetizam o sentimento de toda uma comunidade docente que vivenciou a implantação da profissionalização acadêmica, dos novos prazos e procedimentos avaliativos. Concluí-se a partir de sua análise que os professores titulares entrevistados construíram suas carreiras com a pressão de manter uma produção acadêmica original e de grande impacto e, ao mesmo tempo, atender a uma demanda crescente por pareceres e avaliações institucionais. A conclusão de Adorno sugere que os professores pertencentes a essa comunidade que participou diretamente da concretização da institucionalização docente, assumiram a dupla responsabilidade de 
manter uma produção acadêmica de qualidade, necessária e imprescindível para a manutenção e renovação da Faculdade de Filosofia, e evitar as incongruências e prejuízos causados pela mera reprodutibilidade técnica.

As narrativas docentes acenaram para a necessidade das pesquisas desenvolvidas no âmbito da FFLCH-USP serem avaliadas através de critérios específicos e que levassem em conta parâmetros qualitativos ao invés de quantitativos. É possível observar, além disso, uma preocupação comum entre os docentes em relação à especificidade da área de humanas e a repeito dos choques impelidos pelas novas exigências e prazos impostos às pesquisas desenvolvidas. Para muitos professores a chamada "lista dos improdutivos" representou um marco na desqualificação do trabalho acadêmico e das atividades desenvolvidas na universidade por não ter levado em conta os vários aspectos da vida universitária que compõem o ensino, a pesquisa e a extensão.

De uma maneira geral, os docentes acreditam que os prazos delimitados pelas agências financiadoras prejudicam a qualidade das pesquisas realizadas pelas áreas de conhecimento contempladas na Faculdade de Filosofia. Alguns afirmaram que os métodos avaliativos também são problemáticos porque envolvem não só uma questão quantitativa, mas, muitas vezes, podem distorcer a própria produção do trabalho intelectual. Como ressaltaram outros professores, talvez haja trabalhos científicos que utilizam a coleta de dados e a seleção dos mesmos, em que a questão quantitativa possa ser controlada de forma apropriada. No caso das humanidades, há muita dificuldade em avaliar adequadamente, principalmente quando critérios qualitativos são desprezados.

Faz-se necessário obervar que o episódio da "lista dos improdutivos" marcou a memória coletiva da comunidade docente como uma tentativa de controlar o trabalho acadêmico produzido pela universidade pública e, além disso, explica para muitos as origens da resistência que foi criada em relação à avaliação docente. Destarte, impeliu os professores a assumirem novas responsabilidades, inclusive a de desenvolverem critérios avaliativos contrários ao produtivismo e capazes de levar em conta a diversidade das áreas do conhecimento que dão conformidade ao mundo universitário.

Pressionados entre a necessidade de desenvolver mecanismos que levassem em conta uma produção acadêmica periódica e de grande intensidade e, ao mesmo tempo, garantissem que as especificidades da área de humanidades fossem reconhecidas, muitos passaram a reivindicar uma reorganização da Faculdade de Filosofia que levou a formalização de uma proposta de divisão de sua estrutura administrativa e acadêmica 
em institutos independentes. A proposta de divisão da FFLCH-USP provocou um grande debate no qual se acirraram as divergências internas que serão examinadas a seguir.

\subsection{Uma casa aquinhoada.}

Um intelectual precisa de um lar para desenvolver suas ações... O ETHOS é esse espaço de autonomia ${ }^{136}$.

A proposta de divisão da FFLCH-USP foi pautada e resultou de um conjunto de transformações ligadas à redemocratização política. Como visto no primeiro item desse capítulo, os posicionamentos dos docentes em relação ao papel dos intelectuais e suas relações com a política e a esfera governamental foram diversos. As divergências institucionais no interior da comunidade docente também foram se tornando cada vez mais explícitas à medida que o fortalecimento das instituições democráticas avançou. Nesse momento será traçado um panorama a respeito da maior discórdia ocorrida entre os docentes da FFLCH-USP: a querela em torno da sua unidade administrativa.

Uma grande consulta ocorrida em 1996 envolvendo docentes e discentes em torno da divisão ou não da Faculdade de Filosofia, acabou mantendo unida essa instituição. A questão da divisão da FFLCH desde então foi analisada por autores que averiguaram os principais argumentos favoráveis e contrários a tal proposta ${ }^{137}$. No presente estudo, esse tema faz-se relevante porque mobilizou toda a academia e envolveu diretamente a comunidade docente forjada entre a ditadura e a democracia, tendo se transformado em um dos marcos mais significativos de sua trajetória coletiva. Aliás, o debate em torno da divisão da FFLCH-USP foi particularmente importante porque promoveu um intenso e longo debate entre os docentes. Desde então, se existe uma questão capaz de reunir todos os departamentos da FFLCH-USP, está é o da sua unidade administrativa.

As ocasiões nas quais o tema da divisão foi debatido permitiram que viesse a público a concepção de cada docente a respeito da participação da FFLCH-USP no conjunto da universidade, das relações existentes entre os departamentos e dos projetos

\footnotetext{
${ }^{136}$ Matos, O. Entrevista concedida ao autor. Ver volume 2 do presente trabalho.

${ }^{137}$ Destaca-se o trabalho de Maria de Fátima de Paula, já citado anteriormente. Ver: FÁTIMA DE PAULA, M. de. A modernização da universidade e a transformação da intelligentzia universitária. Op. cit.
} 
coletivos que deveriam ou poderiam mobilizar as atividades internas. Através do exame desses embates foi possível ainda compreender o alcance dos planos e objetivos que a comunidade docente tem para a FFLCH e verificar quais os projetos de futuro que permanecem em gestação.

Conhecida por ser uma das propositoras do projeto de divisão da FFLCH, Eunice Durham defendeu durante a entrevista concedida que os professores favoráveis à unidade da Faculdade de Filosofia podem ser considerados "viúvas da Maria Antônia". Sua maneira provocativa de lidar com temas polêmicos, procura desqualificar os argumentos que tentam vincular o contexto atual à realidade vivida pela Maria Antônia antes da Reforma de 1968 e da transferência de suas atividades para a cidade universitária. Além disso, a professora atacou em sua fala justamente a construção e reivindicação de uma memória em torno da antiga Maria Antônia como "umbigo da universidade" e que tenta encontrar no presente as mesmas condições de diálogo existentes naquela época entre diferentes áreas do conhecimento. Durham explicitou ainda em seus comentários uma série de argumentações técnicas que consideram a unidade da Faculdade extremamente prejudicial ao desenvolvimento dos departamentos:

Em nenhum lugar do mundo existe algo semelhante à nossa Faculdade de Filosofia, Letras e Ciências Humanas como a nossa. E nem no Brasil. Quando você começa a estudar se depara com essa coisa esdrúxula. Na Congregação, Ciências Sociais e Letras não se entendiam. Não havia nenhum curso comum entre essas três áreas. Não havia nada em comum a não ser o mito da Velha Faculdade de Filosofia. Eu lutei muito para que nos separássemos. Acho que essa intransigência e esse tradicionalismo da Faculdade de Filosofia, desse seu passado heroico e mítico, fez dela uma Faculdade cega em relação ao resto da universidade. As coisas não chegam até ela porque ela tem pouca representação no Conselho Universitário. A FFLCH pensa que é o centro do mundo universitário! E ela não é. Na verdade ela precisava ter unidades menores e mais dinâmicas. Isso seria mais interessante do que ficarmos mergulhados naquela ideia de que somos a visão crítica da universidade. Não somos. Não temos uma visão de universidade. Estamos extremamente isolados pelo nosso excesso de tamanho.

Outros professores quando solicitados para falar sobre a questão da divisão da FFLCH-USP, denunciaram a falta de diálogo entre os departamentos e a inexistência de projetos de pesquisa desenvolvidos em conjunto como sintomas de uma fragmentação já existente em sua prática cotidiana. Janine Ribeiro questionou, inclusive, se vale a pena discutir a sua divisão administrativa diante do quadro atual: 
Volto a insistir, quais são os desafios da FFLCH e da universidade? A Faculdade de Filosofia, Letras e Ciências Humanas é uma faculdade muito dividida. No fundo há pouquíssima importância discutir a sua divisão administrativa. Independentemente de se dividi-la em mais ou menos faculdades, o fato é que hoje a pesquisa de uma área dificilmente dialoga com a de outra. Mesmo dentro da mesma área, o diálogo é raro. O Brasil tem pouco diálogo acadêmico, pelo menos nas áreas de humanas. Isso está ligado também a uma característica das áreas de humanas em face das áreas laboratoriais, das exatas ou biológicas.

Para Janine Ribeiro a divisão administrativa foi proposta como consequência da inexistência de projetos coletivos capazes de mobilizar pesquisadores das diferentes áreas do conhecimento pertencentes à Faculdade de Filosofia. Segundo o professor, um tema de interesse mútuo poderia reunir os diversos departamentos e propiciar um diálogo entre as partes que possibilitaria a efetiva construção de uma unidade atenta às novas exigências do mundo contemporâneo.

As indagações de Janine Ribeiro pretendem cobrar das ciências humanas uma postura diferente em relação ao trabalho coletivo no desenvolvimento de pesquisas multidisciplinares e interdisciplinares:

Ao pensarmos a FFLCH em suas áreas básicas, Filosofia, História, Geografia, Antropologia, Ciência Política, Sociologia, Letras e Linguística, em termos de CAPES e suas tabelas das áreas de conhecimento, temos quase a grande área inteira dos cursos de humanas numa faculdade só da USP, que ainda reúne boa parte da grande área de Letras, Linguística e Artes. Pois bem. Do que conheço da FFLCH e de todas essas áreas, não vejo no Brasil nenhum mega projeto reunindo as Humanas, as Letras e as Artes. Poderia dizer que os antropólogos estão preocupados com a questão dos índios, mas não há um mega projeto. Para exemplificar, o equivalente disso para mim na física é o Laboratório Nacional de Luz Síncrotron.

As dificuldades de diálogo, os entraves burocráticos e os impasses departamentais levaram alguns professores descontentes com a realidade da FFLCH-USP a proporem a superação desse modelo e a criação de novas opções disciplinares. Por entender que esta instituição encontrava-se impossibilitada de integrar-se e oferecer uma formação que privilegiasse o encontro e o diálogo entre as diferentes disciplinas que oferece individualmente, Janine Ribeiro organizou a proposta de um novo curso de graduação para a USP, intitulado "Humanidades": 
O Curso de Humanidades que propus para a USP tinha um teor pósmoderno, o que levou alguns a criticarem-no, como Marilena Chauí. Onde eu concordo que haja um fator pós-moderno é no fato de que o curso não acredita na verdade. $\mathrm{O}$ objetivo seria formar as pessoas de modo que entendessem que várias linguagens - desde a Antiguidade até hoje - permitem compreender os fenômenos sociais e humanos. E que não existe uma totalização possível dessa linguagem. Nesse sentido há uma divergência em face do marxismo e das explicações totalizantes. A ideia era que a pessoa aprendesse várias linguagens e, a partir daí, se conseguisse um resultado mínimo: o aluno saber que para tratar de tal fenômeno, tal linguagem é melhor e, para outro, outra linguagem; e um resultado máximo: forçar o aluno a pensar, a criar uma teoria nova, que não precisaria ser totalizante, mas seria sua contribuição realmente original ${ }^{138}$.

Ao propor o curso de Humanidades, seu idealizador partiu do pressuposto de que o projeto que deu origem à FFLCH-USP estava ultrapassado a tal ponto que exigia a fundação de um novo espaço acadêmico. A proposta de uma nova faculdade refletia, assim, o teor avançado de divergências teóricas, políticas e ideológicas no interior de uma comunidade docente que vivenciou o nascimento da crítica à modernidade e a ascensão das chamadas posições "pós-modernas"; tópicos que serão abordados no próximo capítulo.

Diferentemente de Renato Janine, Arrigucci Jr. ponderou a respeito da possibilidade de se criar um novo espaço, concretizado pela inter-relação de diferentes departamentos e disciplinas, no interior da própria FFLCH-USP. Esse curso, talvez uma pós-graduação, seria expressão e resultado de elementos essenciais presentes na própria história da instituição e teria como objetivo a formação de pesquisadores e críticos à maneira moderna:

É necessário criar dentro da FFLCH um lugar onde pudesse haver um maior cruzamento real dos discursos da História, das Ciências Sociais, da Filosofia e das Letras: estas coisas que são muito próximas, mas podem se distanciar irremediavelmente. Então nós teríamos que ter algum centro que formasse um ideal de crítico! O ideal de crítico do Machado de Assis para o nosso tempo! Mas bem formado e que possa formar estudantes das novas e futuras gerações. Penso em um centro de excelência, desde que se atenda a grande massa, mas que também

\footnotetext{
${ }^{138}$ O projeto elaborado por Janine encontra-se em: RIBEIRO, R. J.. Humanidades - um novo curso na USP. São Paulo: Edusp, 2001.
} 
forme essa elite do conhecimento sem a qual não há modo de como produzir o novo. Se abolirmos completamente isso, não conseguiremos mais nos renovar e renovar a universidade. Tem que haver um lugar para pensar o futuro, de onde virão as coisas. Tem que haver um lugar onde os discursos se cruzem de fato, em que o espírito que regeu a fundação da Universidade de São Paulo em 1934 esteja presente, mas diante das condições atuais do conhecimento e das condições da vida presente. Nós não podemos prescindir mais do cruzamento desses discursos. É impossível estudar Literatura sem articular com a História, com a Linguística, com a Filosofia e as Ciências Sociais.

Arrigucci Jr. ao projetar a construção desse novo espaço na FFLCH-USP, reivindica princípios interdisciplinares que seriam responsáveis pela formação de um crítico ideal, essencialmente moderno, capaz de interpretar problemas sistêmicos e elaborar avaliações preocupadas com a totalidade.

Sandra Nitrini, partidária da manutenção da unidade da FFLCH-USP, conviveu no final de seu mandado como diretora desta instituição com a pressão de alguns professores que novamente quiseram colocar em pauta a necessidade de dividir a faculdade. Em sua narrativa, alertou para o fato de que, uma vez dividida em vários institutos, essa instituição deixaria de ter a influência e a "força intelectual" que historicamente construiu em relação à universidade:

Quanto aos desafios que a FFLCH-USP ainda tem que enfrentar, é importante em primeiro lugar, destacar que ela é complexa, embora não concorde com a visão de que ela não é administrável! Essa leitura é equivocada. Ela é administrável, sim. Basta sermos competentes para geri-la. Além disso, estou convencida da importância de sua unidade. De vez em quando, há movimentos que clamam por uma separação dos diferentes cursos que compõem nossa Faculdade de Filosofia Letras e Ciências Humanas! Claro que não podemos impedir essas manifestações. Tenho a preocupação de não ser conservadora. Mas acho que se a FFLCH-USP vier um dia a se dividir e vier a se multiplicar em institutos, será muito difícil para nós construirmos, nessas condições, uma trajetória capaz de conservar o prestígio e a força intelectual que a Faculdade de Filosofia tem. Nenhum Instituto vai recuperá-los em pouco tempo. Se conseguir, só depois de muitos anos de trabalho. O prestígio da nossa Faculdade, o seu peso... Minha experiência como diretora da Faculdade de Filosofia me mostrou que a universidade quer nos ouvir nos momentos de crise, a universidade quer ouvir o que a Faculdade de Filosofia pensa e que atitude ela está tomando.

Nós temos aqui dentro muitos que querem a nossa divisão. Agora, sinceramente, torço para que isso não ocorra. Ela tem uma configuração ímpar, inusitada no mundo inteiro! 
Leopoldo e Silva, também defensor da unidade da FFLCH-USP, quando perguntado a respeito da sua divisão, destacou que nos anos 1990 o debate girava em torno de argumentos que procuravam discutir qual era o seu papel acadêmico no interior da universidade e, inclusive, sua atuação política como instituição, bem como a sua relação com a sociedade. Recentemente, para sua decepção, pontuou o professor, apenas questões de ordem administrativa foram enumeradas por aqueles favoráveis à divisão. Entre suas preocupações, destacou ainda como o distanciamento entre os departamentos tem se expressado no cotidiano e pode ser observado quando os próprios alunos já não se reconhecem como membros efetivos de uma Faculdade de Filosofia, Letras e Ciências Humanas:

\begin{abstract}
Existe um grupo mais atuante de alunos que é contrário à divisão, mas as novas gerações de professores não têm evidentemente muito apego a uma coisa que, na prática, ficou abstrata. Falo da antiga Faculdade de Filosofia que está, cada vez mais, difícil de visualizar. Presto atenção, às vezes, no que aparentemente é um simples detalhe, mas, na verdade, se trata de um detalhe significativo. Por exemplo, teses de mestrado onde aparece escrito na capa apenas "Faculdade de Letras", ou "Faculdade de História". Já vi isso! Ou seja, passou pelo aluno, pelo orientador, pela Comissão e ninguém reparou naquilo que é um detalhe... Mas um detalhe expressivo. $\mathrm{O}$ fato de que as pessoas já não fazem ideia de onde estão. $\mathrm{O}$ fato da existência da Faculdade de Filosofia, Letras e Ciências Humanas tornou-se quase que uma abstração. E isso é uma coisa que milita a favor da divisão, a gente tem que reconhecer. Eu sempre fui contrário à divisão, mas hoje a FFLCH-USP é uma ideia e, mesmo assim, quando alguém a tem. Às vezes, nem como ideia, ela está presente na cabeça das pessoas.
\end{abstract}

Sandra Vasconcelos está entre os docentes que defenderam a manutenção da unidade da FFLCH e ainda mantém a mesma posição. Vasconcelos durante a entrevista apresentou argumentos contrários à tese de que uma vez dividida em institutos independentes, haveria maior quantidade de recursos disponíveis porque teriam mais autonomia administrativa:

Em se tratando da divisão da FFLCH, em 1996 estive do lado da não separação. Conversei muito sobre isso com um colega que é mais novo em idade e em tempo de FFLCH, e ele é completamente favorável à divisão. Acho que a questão necessita ser atualizada. É necessário ouvir ambas as partes. Eu, particularmente, gosto da ideia da faculdade unida. Eu gosto desse projeto. Acho que tem a ver com a origem dela. Com tudo que ela já fez, com tudo que ela já foi. Tudo que ela representa e tudo que ela representou. E acho que a divisão da 
FFLCH pode nos enfraquecer. Acho que o argumento de que a divisão pode nos fortalecer é um pouco falacioso. Um dos argumentos muito utilizados na época queria a divisão em dois ou três institutos, ou seja, sempre pensando na exclusão da Faculdade de Letras. Acho que a Letras é considerada um peso para a FFLCH. Peso inclusive numérico, pelo número de professores, número de alunos, número de problemas. A gente é um peso, reconheço isso. Mas isso pode ser visto de uma forma positiva ou de uma forma negativa. Muita gente vê de uma forma negativa e quer se livrar desse estorvo.

A imagem da FFLCH hoje é muito negativa, na mídia e entre os próprios colegas de outras unidades. Enfim, eu ainda gosto da ideia de uma Faculdade de Filosofia que talvez funcionasse de outra maneira. Porque na verdade o que foi acontecendo é que os departamentos, a universidade como um todo e, a Faculdade de Filosofia em particular, foram funcionando burocraticamente no sentido de uma atomização cada vez maior e não de uma autonomização cada vez maior. Então os departamentos funcionam de uma forma autônoma e praticamente independente.

Vasconcelos reconheceu em suas declarações que a FFLCH-USP encontra-se dividida em seu cotidiano devido ao processo de departamentalização instituído pela Lei 5540/68, mas refere-se ao projeto original da antiga Faculdade de Filosofia como uma oportunidade de fortalecer as pesquisas e a instituição como um todo.

Janice Theodoro Silva não tem uma posição formada a respeito da divisão da FFLCH-USP, mas concorda com Vasconcelos que essa proposta "mata o cerne do projeto original: de pensar a Faculdade de Filosofia como um sprit de corp... Quer dizer, um espírito do corpo todo". Em contrapartida, compreende os argumentos daqueles que acreditam que a divisão pode contribuir para um melhor gerenciamento dos problemas de cada departamento:

A unidade transformou-se, com o passar dos anos, numa utopia. Quando por questões administrativas já não existe uma costura legítima que permita ao aluno fazer cursos onde queira, a unidade já não existe. Com o crescimento das unidades tornou-se impossível a circulação dos alunos. É muito difícil gerenciar tudo, uma massa muito grande de alunos. A descentralização se impôs. Cuidar de uma casa já é difícil, cuidar daquela faculdade toda é bem mais. Tanto que o prédio está sempre caindo. Se do ponto de vista administrativo a divisão da FFLCH fosse resultar em uma melhor administração, com recursos melhor aproveitados, eu não veria problemas na divisão. Embora entenda a posição dos dois lados. De quem queria separar e de quem queria a manutenção. Não tenho uma posição final de qual teria sido a melhor alternativa. A única coisa que vejo, por exemplo, quanto à administração do prédio da História, é que a falta de autonomia e recursos torna a administração inviável. 
Contrário à posição de Theodoro da Silva, Leopoldo e Silva não concorda que o "gigantismo" da FFLCH comprometa a sua administração. "Participei da primeira discussão sobre a divisão da FFLCH. Formaram-se duas comissões para coordenar o debate, uma favorável e outra contra a divisão. Eu fiz parte da comissão que coordenava e defendia a unidade", comentou o professor. Para além das questões administrativas internas, Leopoldo e Silva reivindicou a necessidade de se pensar a questão da unidade da Faculdade de Filosofia no que diz respeito à sua missão institucional e do seu papel em relação à sociedade:

Fizemos muitas reuniões, muita pesquisa sobre a história dessa questão e sobre a situação da universidade em geral em seus vários aspectos e unidades. Lembro até de ter ido à Politécnica que é maior do que a FFLCH para verificar o seu funcionamento. Um dos argumentos utilizados por aqueles que defendiam a separação era a impossibilidade administrativa devido ao gigantismo. Nossa comissão esteve na Politécnica e pudemos acompanhar que eles não tinham problemas desse tipo e não pensavam em se dividir de forma alguma. E apesar de ser muito grande e complexa a Politécnica era administrada com naturalidade. Isso nós fizemos para mostrar aos colegas que não existe uma relação necessária entre uma unidade ser muito grande e impossível de ser administrada. A prova era a Politécnica, mas, na verdade, tínhamos que promover outros argumentos também importantes além desse. Falo dos argumentos de caráter político, sobretudo a cerca do papel da Faculdade. Em primeiro lugar era precisado pensar no papel da Faculdade quando da sua fundação, qual o papel que estaria reservado a ela pelos seus fundadores e qual foi o papel que ela efetivamente desempenhou. Depois, era preciso pensar no significado da primeira divisão que ocorreu por conta da própria universidade quando os departamentos de ciência e suas cadeiras se transformaram em institutos. Essa divisão mostrava, segundo muitos, que era impossível preservar a Faculdade de Filosofia na sua integralidade, já que ela já havia sido desmontada. Argumentava-se, assim, que a nova divisão deveria acompanhar o processo que já tinha ocorrido pela reforma universitária.

Sérgio Adorno defendeu a necessidade de se retomar o debate sobre a unidade administrativa da FFLCH-USP no presente. Esse, aliás, foi um dos compromissos estabelecidos por ele durante a campanha para a direção da instituição:

Como diretor, estou ainda mais impressionado com a FFLCH-USP, com a diversidade dela! Eu imaginava, mas eu não tinha ideia de que ela tinha tamanha diversidade! Estou conhecendo professores que fazem pesquisas fantásticas! Mas isso acontece em um silêncio assustador... Então, diante disso, quais são os meus desafios? Meu principal desejo é que a Faculdade precisa se repensar enquanto 
unidade e projeto acadêmico. Ela precisa pensar o que ela quer. Quando me candidatei, não o fiz com a bandeira de dividir a Faculdade. Minha candidatura apresentou a proposta de colocar isso em discussão. Acho que o momento para isso irá aparecer. Eu não serei o provocador, em algum momento a discussão irá aparecer. Isso significa que temos que discutir um pouco o que fazemos e para onde vamos. Nós temos poucas oportunidades para debater, por exemplo, quem são os historiadores que nós queremos formar? Quem são os sociólogos que nós queremos formar? Quem são os professores de Língua e Literatura que nós queremos formar? Nós temos poucas oportunidades para fazer isso. Acho que essas são questões fundamentais. O que, afinal, é produção do conhecimento para nós hoje? O que é circulação do conhecimento? Tudo isso, então, envolve repensar várias coisas na Faculdade.

De alguma forma a questão da divisão da Faculdade de Filosofia ainda paira no horizonte da comunidade docente. Para seus defensores, institutos menores otimizariam a avaliação dos cursos, promoveriam um melhor desempenho acadêmico dos docentes e, principalmente, facilitariam a conquista de recursos financeiros para pesquisas. Ainda segundo seus argumentos, institutos independentes não estariam presos às amarras de uma estrutura burocrática ultrapassada e economicamente pouco eficiente. Consequentemente, agindo de maneira isolada os atuais departamentos teriam melhores condições de definir suas prioridades e conquistar recursos extras. Dessa forma, as questões da produção acadêmica e da avaliação para aqueles que defendem a divisão, passam necessariamente pela reorganização administrativa da Faculdade.

Para os docentes que defendem a unidade da FFLCH-USP, a referência à Maria Antônia, faz parte da elaboração de um argumento político que se sustenta a partir da defesa da especificidade do trabalho intelectual na área de humanas. Segundo seus propositores, a divisão da Faculdade diminuiria a sua representatividade institucional e a capacidade das áreas de conhecimento nela abrigadas resistirem à imposição de prazos de pesquisa cada vez mais curtos e exigirem critérios avaliativos capazes de levar em conta a qualidade dos trabalhos produzidos. Os adeptos da manutenção da unidade, por sua vez, ao reivindicarem o papel político desempenhado pela antiga Faculdade de Filosofia, acreditam que ela ainda tem um papel público a cumprir no presente.

Tanto aqueles que se colocam em posição favorável pela divisão da FFLCH-USP quanto os que se definem contrários a essa tese, reconhecem que há pouco diálogo interno entre os cursos. A principal diferença é que os primeiros não acreditam que a estrutura administrativa atual permita o desenvolvimento de trabalhos envolvendo 
diferentes disciplinas, enquanto o segundo grupo entende que a organização de institutos independentes facilitaria a gestão dos departamentos e cursos que, na prática, já tem caminhado de maneira independente. Em ambos os casos, o peso atribuído à história da instituição é muito significativo e, como toda relação com o passado é travada no presente, o debate em torno da divisão da FFLCH-USP faz parte de uma disputa pela memória que é construída em relação à Faculdade de Filosofia da Rua Maria Antônia na contemporaneidade.

Todas as vezes em que se tocou no tema da divisão da FFLCH, as articulações e rearticulações da memória no tempo presente trouxeram para o centro do debate a questão da Faculdade de Filosofia alocada na Rua Maria Antônia. Seja para negar os vínculos entre a atual faculdade e a Maria Antônia, seja para estabelecer relações de permanência entre os seus propósitos na atualidade, as memórias trabalham, agrupam e reagrupam informações e desejos de acordo com interesses e projetos estabelecidos na atualidade. Nesse sentido, uma das marcas mais características da comunidade acadêmica formada entre a ditadura e a democracia consiste na utilização da Faculdade de Filosofia da Rua Maria Antônia como referência política, seja para negar o seu modelo, seja para preservar e defender algumas das suas concepções. A Maria Antônia tornou-se, assim, uma espécie de fronteira que marca as balizas do imaginário coletivo dessa comunidade docente forjada no contexto de transição política.

O tema da divisão sempre veio acompanhado de questões referentes aos vários problemas existentes na faculdade, sedimentando dados e informações sobre o seu funcionamento e possibilitando avaliações mais matizadas a respeito da complexidade de sua gestão. Estariam os docentes da Faculdade de Filosofia fadados a estabelecer um diálogo institucional apenas nos momentos em que se instala um processo de crise sistêmica?

No próximo capítulo, a comunidade docente formada entre a ditadura e a democracia será situada no contexto dos debates em torno do papel dos intelectuais no mundo contemporâneo. Destarte, discutir-se-á a questão da autonomia universitária e seus reflexos nas relações estabelecidas entre universidade pública e sociedade. 


\section{Capítulo 3 - Entre a profissão e a docência: memória coletiva e universidade pública.}

O destino de toda visão utópica está vinculado ao destino dos intelectuais, pois se em algum momento a utopia pode sentir-se em casa, é entre os pensadores independentes e nos cafés por eles frequentados. Na medida em que estes já não existem, a visão utópica esmorece $^{139}$.

Hoje, na minha visão, a universidade é um dos últimos espaços onde existe uma aproximação em relação à utopia na sociedade moderna ${ }^{140}$.

\subsection{Intelectuais e espaço público em debate.}

A publicação do livro Os últimos intelectuais: a cultura americana na Era da academia imediatamente chamou a atenção dos acadêmicos brasileiros porque oferecia explicações a respeito do desaparecimento dos intelectuais públicos nos Estados Unidos e relacionava a sua ausência ao fenômeno da profissionalização e, especificamente, à institucionalização acadêmica ${ }^{141}$. "Os sociólogos radicais podem sonhar com a revolução, mas investem em sua profissão", concluía Jacoby ao questionar a adesão dos intelectuais a uma espécie de ostracismo originado pela carreira universitária.

Analisando a condição dos intelectuais na América do Norte e na Europa ocidental, portanto, um contexto social no qual a democracia política, bem como as universidades, já se encontravam em um estágio avançado de amadurecimento em relação ao Brasil, Russel Jacoby alertou para o fato de que as carreiras acadêmicas minavam a liberdade dos intelectuais:

À medida que obtinham postos na universidade, os intelectuais da Nova Esquerda passavam a desfrutar de benefícios: salários regulares,

\footnotetext{
${ }^{139}$ JACOBY, R. O fim da utopia: política e cultura na era da apatia. Rio de Janeiro: Record, 2001, p.139. 140 "Now, in my view, the university is one of the last quasi-utopian spaces in modern society". Entrevista concedida por Edward Said em junho de 1992, em Londres, para Anne Beezer e Peter Osborne. Ver: OSBORNE, P. (ed) A Critical Sense - interviews with intellectuals. London: Routledge, 1996, p. 80.

${ }^{141}$ Publicada originalmente em 1987, chegou ao Brasil através de uma parceria entre a Edusp e a Editora Trajetória Cultural em 1990. Ver: JACOBY, R. Os últimos intelectuais - a cultura americana na era da academia. São Paulo: Edusp, 1990.
} 
férias prolongadas e a liberdade de escrever, e às vezes ensinar o que queriam. Evidentemente, não era tão simples assim. Muita insegurança ronda o empreendimento acadêmico. O futuro de um indivíduo dependia de um complexo conjunto de avaliações realizadas por colegas e por administradores. A própria liberdade acadêmica era frágil e seus princípios frequentemente ignorados. Essas avaliações não estavam também restritas a administradores intrometidos ou investigadores externos. A ameaça provinha, talvez de modo crescente do próprio interior; as carreiras acadêmicas minavam a liberdade acadêmica. Isso pode ser um paradoxo, mas evoca uma condição inerente a liberdade acadêmica - a instituição neutraliza a liberdade que garante. Para muitos professores, em muitas universidades, liberdade acadêmica significava nada mais do que a liberdade de ser acadêmico $^{142}$.

A universidade para Jacoby teria se tornado uma armadilha para os intelectuais que, consumidos pela burocracia e dedicados unicamente a cumprir exigências para a progressão na carreira, acabavam abandonando o compromisso com as questões públicas mais amplas. O debate em torno dos intelectuais foi enriquecido, anos mais tarde, quando Edward Said teceu considerações menos ostensivas à universidade, interpretando-a como um dos últimos espaços da sociedade moderna onde uma aproximação em relação à utopia era possível. Nesse sentido, a própria trajetória acadêmica de Said apresentava o potencial crítico existente no interior da universidade e de seus intelectuais, ao trabalhar no sentido de estabelecer um diálogo efetivamente público.

A compulsão dos memoriais, o trabalho de campo e a realização das entrevistas de história oral mostraram que as proposições formuladas por Jacoby, apesar das instigantes contribuições, precisavam ser problematizadas. O autor de $O$ fim dos intelectuais tinha razão ao afirmar que a universidade e a carreira acadêmica foram responsáveis por conceber um novo contorno à atividade intelectual, mas, seria mesmo a nova condição profissional oferecida pelas universidades públicas a responsável direta pelo afastamento desses em relação à esfera pública? Teria a universidade força suficiente para destituir seus professores de autonomia e independência intelectual? Pessimista em relação ao processo de institucionalização, Jacoby chegou a afirmar que as universidades somente contratavam intelectuais com postura agradável e conivente com as regras, ou seja, incapazes de fomentar a crítica ao próprio sistema ${ }^{143}$. A hipótese

\footnotetext{
${ }^{142}$ JACOBY, R. Os últimos intelectuais - a cultura americana na era da academia. Op. cit., p. 131.

${ }^{143}$ A análise de Jacoby ressalta os problemas relativos à institucionalização acadêmica dos intelectuais: “as universidades estimulam uma forma intelectual definida. Elas não expulsam, simplesmente não
} 
de Jacoby, contudo, parecia ignorar as relações acadêmicas como um espaço de conflito inserido no interior da sociedade e em diálogo permanente com esta.

Uma vez comparadas as posições de Jacoby e Said, notou-se que a principal diferença entre as análises dos autores quanto aos intelectuais que trabalhavam em universidades, consistia na relação estabelecida por estes com o processo de institucionalização da carreira acadêmica. Enquanto para o primeiro, a carreira docente moldava o intelectual promovendo sua domesticação, para o segundo, o docente era o único responsável por dar conteúdo à própria carreira universitária, estando capacitado a ultrapassar os limites impostos pela mesma. Portanto, na perspectiva defendida por Said, não se podia negar o fato dos docentes serem sujeitos ativos no cotidiano processo de construção e reconstrução da universidade, bem como capazes de resistir e avaliar criticamente a institucionalização.

Os primeiros ensaios preocupados com a questão da institucionalização dos intelectuais no Brasil surgiram no final da década de 1970 no contexto da (re)introdução do debate em torno da democracia. Naquele momento, as apreciações de Marilena Chauí estavam voltadas para os intelectuais e os partidos políticos que defendiam uma concepção "etapista" da história, baseada em um marxismo vulgar e condescendente com uma democracia limitada e de caráter instrumental. Para a autora, "a fala dos intelectuais, dominando o campo da opinião pública, poderia impor o silêncio a outros sujeitos sociais... mais precisamente, à classe trabalhadora" ${ }^{" 144}$. O alvo de suas críticas eram os intelectuais eivados de postura vanguardista própria à esquerda tradicional que, supostamente, eram incapazes de estabelecer uma relação de diálogo com os novos personagens que entravam na cena política brasileira, como os movimentos sociais nos bairros da periferia, as associações de mulheres e o novo sindicalismo. Surgia, assim, como modelo ideal para a autora, um intelectual atento aos novos sujeitos históricos e capaz de compreender as lutas sociais a partir da perspectiva dos próprios trabalhadores.

Mais de trinta anos depois, o intelectual que se impunha com postura autoritária e concepções pré-concebidas diante dos movimentos sociais havia perdido terreno e,

contratam aqueles incapazes ou obstinados demais para se adaptarem a elas. Até Henry Luce, dono do império da revista Time, frequentemente denunciado como um expert no assunto, empregava e até apreciava errantes dissidentes. As universidades, por outro lado, contratam através de comissões: um candidato necessita de títulos universitários, referências, a deferência adequada, um comportamento agradável...”. JACOBY, R. Os últimos intelectuais - a cultura americana na era da academia. Op. Cit., p. 246.

${ }^{144}$ CHAUÍ, M. S. “Intelectual Engajado: figura em extinção?” In: NOVAES, A. (org.) O silêncio dos intelectuais. São Paulo: Cia das Letras, 2006, p. 39. 
curiosamente, as preocupações de Chauí voltavam o seu foco para a ausência de intelectuais engajados e para o que acabaria definindo como "a Era do retorno dos intelectuais para o silêncio de seus trabalhos acadêmicos" ${ }^{145}$.

Bernardo Sorj foi um dos primeiros a descrever a "metamorfose dos cientistas sociais em técnicos especialistas e consultores universitários" que, segundo ele, passaram a depender dos financiamentos de pesquisa como complementação salarial devido ao processo inflacionário nos anos 1980. Segundo Sorj, “a velha oposição USP/ISEB se dissolveu na prática num novo tipo de cientista social com formação acadêmica sólida e visão crítica da sociedade, mas que funciona como especialista (técnico ou consultor) de instituições públicas”. Sorj examinou como o CEBRAP sofreu alterações que provocaram certo esvaziamento com a saída de alguns membros a partir do início do processo de redemocratização e de sua aproximação em relação ao Movimento Democrático Brasileiro $(\mathrm{MDB})^{146}$. Em uma perspectiva mais ampla, este autor observou também como os intelectuais brasileiros tiveram que reorganizar suas atividades diante da sensação de perda de função social:

\begin{abstract}
A organização do Partido dos Trabalhadores, a atuação no seio do PMDB e nos movimentos sociais e sindicatos esvaziam igualmente a universidade como centro de atuação e debate ideológico. Os intelectuais que queriam seguir mantendo uma influência política direta tiveram que se ligar a organizações partidárias e sindicais e aos novos fóruns de debate político - em particular a grande imprensa -, todos eles à margem da vida estritamente acadêmica ${ }^{147}$.
\end{abstract}

A questão do desaparecimento dos intelectuais públicos no Brasil veio à tona com grande impacto quando colocada em pauta por Francisco de Oliveira em artigo publicado em 1985 e intitulado Aves de Arribação: a migração dos intelectuais ${ }^{148}$. Para Oliveira, os intelectuais estavam abandonando a pesquisa e as salas de aula e migrando para a esfera do Estado transformando-se em "gestores do poder". Além disso, o autor ainda observava a renúncia de uma postura crítica, senão, revolucionária em termos marxistas, para aderir aos limites impostos pela fórmula democrática que era anunciada.

\footnotetext{
${ }^{145}$ Idem., p. 30.

${ }^{146}$ Para Sorj, "Embora os controles tenham sido limitados, e os apoios generosos, mais do que influir no conteúdo da pesquisa esses financiamentos tiveram como efeito uma generalização de um novo tipo de acadêmico-técnico, de universitário que adquire uma dimensão tecnocrática”. Ver: SORJ, B. A construção intelectual do Brasil contemporâneo. Rio de Janeiro: Zahar, 2001, p.69-70.

${ }^{147}$ Idem, p.79.

148 OLIVEIRA, F. “Aves de Arribação: a migração dos intelectuais”. Op. cit., pp.20-26.
} 
Desde então, o chamado desaparecimento dos intelectuais públicos e o tema relativo a cooptação dos intelectuais marcou várias análises realizadas no Brasil. Uma grande parte delas foi claramente influenciada pela perspectiva inaugurada por Russel Jacoby, o que permitiu a construção de um panorama bastante completo sobre os vários aspectos relacionados à profissionalização e institucionalização dos intelectuais a partir dos anos 1970 no Brasil.

Recentemente, pesquisas acadêmicas realizadas nas universidades públicas passaram a abordar diretamente as mudanças ocorridas no ensino superior brasileiro e o seu impacto sobre o trabalho intelectual. Maria de Fátima de Paula concluiu a partir de uma pesquisa comparativa que investigou a Universidade de São Paulo e a Universidade Federal do Rio de Janeiro, que os professores formados a partir dos anos 1970 apresentavam características novas e ligadas a um modelo de "especialização científica”. Para Fátima de Paula:

\begin{abstract}
Muitos dos professores universitários da área de humanas que atingiram a maturidade intelectual nos anos 80 foram formados na pós-graduação estruturada nos anos 70 , obtiveram apoio das agências de fomento à pesquisa e fizeram suas teses e obras de maior envergadura já tendo como influência um novo paradigma institucional e de produção científica. Além disso, vivenviaram, sob o signo da abertura política, a crise do paradigma marxista, das ideologias de esquerda e dos modelos de explicação anteriormente assumidos pelas ciências sociais ${ }^{149}$.
\end{abstract}

A tese A produção social do marxismo universitário em São Paulo: mestres, discípulos e um seminário (1958-1978) de Lidiane Soares Rodrigues reconstituiu as biografias dos intelectuais que pertenceram ao chamado Seminário de Leitura de $O$ Capital iniciado em 1958 e responsável pela introdução e leitura sistemática das obras escritas por Karl Marx na academia brasileira. Soares demonstrou como as trajetórias de mestres e discípulos ligados ao grupo elaboraram teses que dialogavam entre si e definiram uma determinada postura em relação à atividade política, afastando-os da militância político-partidária:

E, bem ponderadas as possibilidades, em 1958, um grupo que se dispusesse a ler Karl Marx e introduzi-lo no conjunto dos autores citados nas bibliografias, teses, aulas só lograria seu intento se o

\footnotetext{
${ }^{149}$ FÁTIMA DE PAULA, M. de. A modernização da universidade e a transformação da intelligentzia universitária. Op. cit., p.207.
} 
afastasse ao máximo da política partidária: a juventude da instituição estabelecida, a autonomia recente e conquistada a duras penas - que os seminaristas acompanharam por meio dos conflitos enfrentados por seus catedráticos - recomendava essa distância. Em suma, se o grupo chancelasse a política partidária, ele é que não seria chancelado academicamente $^{150}$. (grifo da autora)

Milton Lahuerta examinou a formação do CEBRAP e o esforço de Fernando Henrique Cardoso e outros professores da USP em manter viva a tradição das pesquisas iniciadas pela "escola paulista de ciências sociais", baseada no questionamento ao nacional desenvolvimentismo e às práticas populistas de Estado e sindicatos. As pesquisas de Lahuerta examinaram ainda como a criação desse novo espaço institucional, onde os intelectuais passaram a ter que buscar financiamento para suas pesquisas, contribuiu para a elaboração de um pensamento de oposição no país:

Tais atributos garantiram aos intelectuais do Cebrap, principalmente entre a juventude universitária, não apenas um público para suas ideias, mas também um forte aliado na luta democrática e na fixação de um conceito de democracia, centrado na ideia de fortalecimento da "sociedade civil" 151 .

A pesquisa de Lahuerta propiciou também uma reflexão a respeito da aproximação dos intelectuais do CEBRAP em relação à agenda política da transição e, em particular, do MDB, que resultaria em uma base consistente de apoio da maioria de seus membros à campanha de Fernando Henrique Cardoso ao senado nas eleições de 1978. Por fim, Lahuerta demonstrou como o avanço do processo democrático interferiu no surgimento de múltiplas avaliações em relação à sociedade civil e provocaram a formulação de posicionamentos políticos e teóricos distintos.

Fábio Cardoso Keinert em sua tese de doutorado Cientistas Sociais entre ciência e política (Brasil: 1968-1985), avaliou como após 1968 os cientistas sociais foram obrigados a lidar com a expansão do sistema universitário e o processo de profissionalização das carreiras. Para este autor, a valorização dos títulos acadêmicos e a exigência de pós-graduação para ingresso na carreira universitária promoveram, aos poucos, uma alteração no perfil dos intelectuais. Fomentando o debate em torno do

\footnotetext{
${ }^{150}$ RODRIGUES, L. S. A produção social do marxismo universitário em São Paulo: mestres, discípulos e um seminário (1958-1978). Tese de doutorado apresentada à FFLCH-USP, 2011, p.56.

${ }^{151}$ LAHUERTA, M.. "Intelectuais e resistência democrática: vida acadêmica, marxismo e política no Brasil”. Cadernos Arquivo Edgard Leuenroth (UNICAMP), v. 8, 2001, p.64.
} 
ensino superior, Keinert explicou ainda como as principais formulações teóricas gestadas por gerações anteriores à legislação militar foram transmitidas às gerações posteriores:

O que importa ressaltar é que o adensamento institucional, no período pós-1968, teve um impacto reduzido do ponto de vista dos laços entre as ciências sociais e as questões paradigmáticas. É possível dizer que a especialização das linhas de pesquisa não excluiu a existência de problemáticas decisivas, em larga medida herdadas das gerações anteriores. Na sucessão geracional, foram as ênfases analíticas e as técnicas de pesquisa que se modificaram, mas sem que isso significasse o declínio do consenso em torno de questões imperativas, caso da temática referente ao Estado brasileiro ${ }^{152}$.

Depois de investigar a produção e atuação de vários artistas e intelectuais revolucionários nos anos 1960, onde se destacava a presença de um imaginário romântico e revolucionário ${ }^{153}$, Marcelo Ridenti constatou o refluxo da brasilidade revolucionária ${ }^{154}$ enquanto "estrutura de sentimento" a partir do início dos anos 1980:

Os tempos mudaram e, especialmente a partir dos anos 1980, já era visível o progressivo trajeto de desaparecimento do intelectual ou artista atormentado com sua condição relativamente privilegiada numa sociedade subdesenvolvida e desigual, como a brasileira. (...) Aos poucos foi se esgotando o arquétipo do intelectual ou artista rebelde, cada vez mais raros nos dias de hoje. Os intelectuais críticos e comprometidos com a superação das contradições da modernidade capitalista tendem a dar lugar a intelectuais resignados, contemplativos das eternas contradições, contra as quais pouco ou nada poderiam fazer $^{155}$.

É possível apreender, a partir das considerações de Ridenti, que os intelectuais e artistas brasileiros resignaram-se e recolheram-se a espaços privados de convívio

${ }^{152}$ KEINERT, F. C. Cientistas Sociais entre ciência e política (Brasil: 1968-1985). Tese de doutorado apresentada à FFLCH-USP, 2011, p. 178-179.

${ }^{153}$ RIDENTI, M. Em busca do povo brasileiro - artistas da revolução, do CPC à era da TV. Op. cit..

${ }^{154}$ Para Ridenti, "hoje se pode identificar com clareza uma estrutura de sentimento que perpassou boa parte das obras de arte, em especial a partir do fim da década de 1950. Amadurecia o sentimento de pertença a uma comunidade imaginada, para usar o termo de Benedict Anderson (2008), sobretudo nos meios intelectuais e artísticos de esquerda ligados a projetos revolucionários. Compartilhavam-se ideias e sentimentos de que estava em curso a revolução brasileira, na qual artistas e intelectuais deveriam engajar-se". Ver: RIDENTI, M. "Brasilidade revolucionária como estrutura de sentimento: os anos rebeldes e sua herança". In: . Brasilidade revolucionária: um século de cultura e política. São Paulo: Unesp, 2010, p. 87.

${ }^{155}$ RIDENTI, M. “Cultura e política brasileira: enterrar os anos 1960?”. In: BASTOS, E. R. \& RIDENTE, M. \& ROLLAND, D. (org.) Intelectuais: sociedade e política. França-Brasil. São Paulo: Cortez, 2003, p.207. 
acadêmico diante das transformações políticas, econômicas e, até mesmo, geográficas ocorridas nos últimos 40 anos. Diante de um contexto de abandono das utopias revolucionárias, de encolhimento do espaço público, de novas formas de inserção do saber, das tecnologias e da universidade no modo de produção capitalista, de que trataram os autores supracitados, tornou-se imperativo avaliar o papel social e político dos docentes da FFLCH-USP enquanto funcionários públicos ${ }^{156}$.

As preocupações formuladas por Jacoby e por vários pesquisadores brasileiros em torno dos efeitos da profissionalização da carreira docente sobre a comunidade docente estudada, em um período de refluxo da brasilidade revolucionária, como definido por Ridenti, orientou a leitura dos memoriais e a realização das entrevistas. Contudo, as referências - muitas vezes negativas - em relação à institucionalização dos intelectuais, foram revistas em prol da averiguação das formas de resistência adotadas pelos professores no interior do processo de profissionalização. Foi preciso investigar como a comunidade docente formada no contexto de transição da ditadura para a democracia política, avaliou através de suas memórias as mudanças ocorridas na esfera acadêmica e o trabalho desempenhado diante das novas exigências políticas e sociais no regime democrático.

Tomados como agentes corresponsáveis pelo processo de profissionalização da carreira docente, os professores titulares foram interrogados quanto ao papel dos intelectuais na contemporaneidade e quanto à importância da área de humanidades e do ensino público. O conjunto de entrevistas revelou histórias de vida acadêmica construídas mediante conflitos travados entre os docentes e o processo de profissionalização. Uma das hipóteses construídas pela pesquisa consistiu em demonstrar como os choques decorrentes de uma institucionalização peculiar provocaram reações diversas e demarcaram a configuração de uma posição intelectual em torno da defesa da autonomia universitária. Além disso, interpretadas pelo ângulo da negociação, as entrevistas permitiram identificar na questão da defesa do ensino público, do papel crítico da Faculdade de Filosofia e da formação de intelectuais independentes, temas através dos quais as memórias individuais se entrecruzaram e deram conformidade à memória coletiva da comunidade docente ${ }^{157}$.

\footnotetext{
${ }^{156}$ CHAUÍ, M. S. “Intelectual Engajado: figura em extinção?”. Op. cit., p. 30.

${ }^{157}$ Conforme explicitado no capítulo 1 , o conceito de memória coletiva é aqui utilizado tomando por base os trabalhos já citados de HALBWACHS, M. e POLLAK, M..
} 
As contradições próprias a uma zona fronteiriça, limitada entre os anos de chumbo e as novas exigências impostas pela perspectiva democrática, possibilitaram a construção de concepções baseadas em experiências de resistência política. Enquanto o papel público dos intelectuais era redefinido e, a olhos vistos, as ameaças em relação à universidade pública se arrefeciam, a comunidade docente da Faculdade de Filosofia reafirmava um ethos baseado na crítica independente e de raízes humanistas e na luta pela autonomia universitária, travada desde os tempos ditatoriais.

Este capítulo pretende demonstrar que o afastamento e a diminuição da presença dos intelectuais em relação ao espaço público devem ser interpretados menos como um fenômeno atrelado especificamente ao processo de institucionalização e profissionalização das carreiras docentes e mais como uma consequência dos novos diálogos estabelecidos no interior da sociedade civil e, desta, com a própria construção e exercício da política. O chamado "fim dos intelectuais públicos" também foi alvo dos questionamentos de Eric Hobsbawm que abordou a questão como um fenômeno atrelado ao contexto internacional de abandono das utopias revolucionárias e de inserção nos "tempos fraturados" impostos pelos novos mecanismos de atuação do modo de produção capitalista. Assim sendo, para este autor:

O declínio dos grandes intelectuais protestativos deve-se, portanto, não apenas ao fim da Guerra Fria, mas à despolitização de cidadãos ocidentais num período de crescimento econômico e ao triunfo da sociedade de consumo. O trajeto que vai do ideal democrático da ágora ateniense às irresistíveis tentações do shopping center reduziu o espaço disponível para a grande força demoníaca dos séculos XIX e XX: a saber, a crença em que a ação política era o jeito de aperfeiçoar o mundo. A rigor, o objetivo da globalização neoliberal era precisamente reduzir o tamanho, o escopo e as intervenções públicas do Estado. Nisso, foi parcialmente bem-sucedida ${ }^{158}$.

Diferentemente de algumas análises catastrofistas, o intelectual público não estaria fadado a um desaparecimento eterno na concepção apresentada por Hobsbawm. O encolhimento da presença dos intelectuais protestativos, uma vez compreendido diante da contração do espaço público nas sociedades ocidentais, foi abordado como um fenômeno reversível e que dependerá, para este autor, da capacidade de reconstrução do diálogo entre as partes envolvidas no século XXI.

\footnotetext{
${ }^{158}$ HOBSBAWM, E. Tempos Fraturados - cultura e sociedade no século XX. São Paulo: Cia das Letras, 2013, p.231.
} 
Diante do debate, tornou-se salutar tomar as perspectivas dos autores supracitados como complementares e não excludentes, afinal, da mesma maneira que a carreira acadêmica molda os intelectuais, estes também interferem na organização dos trabalhos acadêmicos e definem, em negociação com a sociedade, qual a melhor forma da universidade corresponder às suas expectativas. Para adensar o debate sobre a relação entre intelectuais e sociedade, foi necessário ainda adotar outras perspectivas teóricas que se dedicaram a pensar a via recíproca, ou seja, aquela que corresponde à perspectiva que investiga os posicionamentos da sociedade para com os intelectuais.

Concepções antinômicas a respeito do papel dos intelectuais mostraram-se pouco convincentes porque reducionistas e encarceradas a um esgotado modelo dualista. Fugindo aos estereótipos "engajamento" ou "neutralidade", Octávio Ianni contribuiu sobremaneira para a compreensão das relações entre o intelectual e a sociedade e os processos de institucionalização acadêmica. "O que está em questão, pois, não é a dualidade entre 'neutralidade' e 'engajamento', mas conhecer as condições objetivas e subjetivas através das quais se constrói a carreira intelectual”"159.

$\mathrm{Na}$ perspectiva elaborada por Ianni, para se avaliar adequadamente os intelectuais e seu trabalho seria preciso levar em conta as relações e o diálogo estabelecido entre estes e a sociedade, como também entre esta e os intelectuais:

É pouco, pois, colocar o problema em termos de "neutralidade" ou "engajamento". Não se trata de saber e reconhecer se há ou não comprometimento político, religioso, empresarial, governamental do sociólogo ou cientista social. O que está em causa é reconhecer que as condições sob as quais se processa o conhecimento compreendem inclusive o modo pelo qual a sociedade absorve, seleciona, critica ou rejeita o produto da atividade intelectual. Todo esse encadeamento de condições e implicações entra na conformação do alcance da análise, reflexão, explicação ou talento do intelectual. Cabe reconhecer que os movimentos da sociedade, por seus grupos e classes, por suas disparidades de contradições, estão sempre presentes no modo pelo qual são pensados, estão se pensando. Não é apenas a teoria que se põe em prática, nesta ou naquela modalidade; é o movimento da história que frequentemente se decanta em teoria ${ }^{160}$.

\footnotetext{
${ }^{159}$ IANNI, O. Sociologia da Sociologia - o pensamento sociológico brasileiro. São Paulo, Ática, 1989, p.110.

${ }^{160}$ IANNI, O. "Florestan Fernandes e a formação da sociologia brasileira". In: Pensamento Social no Brasil. Bauru: EDUSC, 2004, p.334-335.
} 
As considerações de Ianni reiteram a necessidade de se avaliar a atuação dos intelectuais sem perder de vista as atividades sociais mais amplas. Nesse sentido, a pesquisa pretendeu a partir de uma perspectiva macro-histórica, compreender o contexto particular de formação de uma comunidade docente no transcorrer do processo de profissionalização da carreira acadêmica. Destarte, os docentes da Faculdade de Filosofia foram observados com base na dinâmica política nacional responsável por rupturas e permanências que qualificaram a passagem da ditadura para a democracia no país.

Partindo das premissas elaboradas por Ridenti, investigou-se a estruturação e a profissionalização das carreiras intelectuais entre dois horizontes políticos distintos: os projetos utópicos e revolucionários e as novas exigências e responsabilidades acarretadas pela nascente democracia política, incluídas as elaborações críticas ao nacionalismo e ao populismo. As balizas ideológicas demarcadas pela hegemonia em torno do debate sobre a revolução brasileira e a posterior introdução da questão da democracia e do fortalecimento de suas instituições, qualificaram a memória coletiva da comunidade docente. Esse percurso histórico instruiu a construção de uma identidade de grupo fortalecida por uma convicção em torno da importância do ensino público e de suas responsabilidades enquanto professores e pesquisadores. A (re)democratização da sociedade brasileira tornava essencial reconstruir o diálogo entre universidade e espaço público, mas este já não seria mais realizado como antes, devido às dificuldades impostas pelo novo contexto histórico em relação ao trabalho intelectual.

Partindo do pressuposto de que um dos principais aspectos que diferencia e dá sentido coletivo à comunidade docente pesquisada está no fato de ela ter se profissionalizado entre o ápice e o refluxo da brasilidade revolucionária, adotou-se ainda algumas contribuições baseadas na perspectiva teórica inaugurada por Zygmunt Bauman em Legisladores e Intérpretes - sobre modernidade, pós-modernidade e intelectuais. Este livro sugeriu a elaboração de análises que passaram a levar em conta a condição dos docentes na recente história intelectual, ao situá-los no debate em torno da passagem da modernidade para aquilo que, provisoriamente, foi chamado pelo autor de "pós-modernidade". Portanto, modernidade e "pós-modernidade" ${ }^{161}$ foram tomadas por Bauman como parâmetros para se pensar a prática intelectual:

161 O conceito de "pós-modernidade" elaborado provisoriamente por Bauman, na verdade, dialoga diretamente com o de "modernidade radicalizada" estabelecido por Antony Giddens. Para Bauman, "a 
A serviço da teorização dos três últimos séculos da história europeia ocidental, vistos da perspectiva da prática intelectual. Essa prática é que pode ser moderna ou pós-moderna; a predominância de um ou outro dos dois modos distingue modernidade e pós-modernidade como períodos da história intelectual ${ }^{162}$.

Diante da crise do intelectual público apresentada por Jacoby nos Estados Unidos, surgia na Inglaterra no mesmo ano de 1987, uma abordagem também pioneira e original que procurava compreender a história intelectual como parte integrante de um contexto marcado pelo avanço das contradições de uma modernidade radicalizada ${ }^{163}$. "O mundo contemporâneo é impróprio para os intelectuais como legisladores", afirmava o autor de Legisladores e Intérpretes. O estudo empreendido por Bauman procurou através da criação de duas metáforas, a do "legislador" e do "intérprete", explicar as mudanças ocorridas em relação ao papel dos intelectuais na história.

Neste livro, Bauman contextualizou o intelectual diante de uma modernidade radicalizada, a qual, em seus livros posteriores, denominaria de modernidade líquida ${ }^{164}$. Conforme a sua interpretação, o intelectual legislador havia sido educado em uma vertente moderna e preparado para atuar em um contexto de certezas. Em uma abordagem inovadora, assumir a posição de intérprete significaria aprender a trabalhar outras habilidades e desempenhar funções mais compatíveis diante da "ausência de perspectivas futuras". Mergulhados em uma "Era de incertezas", caberia aos intelectuais, enquanto intérpretes, a condição "pós-moderna" de contribuírem como tradutores e facilitadores ao estabelecerem vínculos de comunicação entre tradições culturais diferentes. Segundo Bauman, ao tomarem para si a criação de novos valores

ideia de pós-modernidade pereceu-me desde o início uma solução provisória para o dilema. (...) o que achei menos aceitável nessa ideia foi a presunção de que 'a era da modernidade' terminou e que estamos, por assim dizer, já no 'lado oposto', ou pelo menos perto de entrar nele. Parecia inaceitável e errado, porque, até onde eu sabia, éramos modernos por completo; na verdade, mais modernos que nunca". Ver: BAUMAN, Z. Op. cit., p.11.

${ }^{162}$ BAUMAN, Z. Legisladores e Intérpretes - sobre modernidade, pós-modernidade e intelectuais. Rio de Janeiro: Zahar, 2010, pp.17-18.

163 Giddens entende que as transformações ocorridas em escala mundial no final do século XX correspondem à radicalização das contradições presentes na própria modernidade (modernidade radicalizada) e, portanto, são consequências de um processo que avança. Nesse sentido, tais alterações não representam indícios de uma Era "pós-moderna". Enquanto os formuladores da chamada "pósmodernidade" defendem a "impossibilidade do engajamento político coordenado", para Giddens, observar as mudanças contemporâneas pela ótica da modernidade radicalizada significa, entre outras coisas, compreender que "o engajamento político não só é possível como se faz necessário, tanto num nível global como localmente”. Ver: GIDDENS, A. As consequências da modernidade. São Paulo: Unesp, 1991, 132-133.

${ }^{164}$ Ver: BAUMAN, Z. Modernidade Líquida. Rio de Janeiro: Zahar, 2001. 
sociais, Estado e mercado foram responsáveis por expropriar os intelectuais no contexto da modernidade radicalizada, o que teria não só provocado a perda de algumas atribuições e funções sociais mas, principalmente, a dificuldade de atuar e influenciar decisões tomadas no espaço público ${ }^{165}$.

Não foi exatamente a bipolaridade apresentada por Bauman, mas a abordagem problematizadora trazida por sua hipótese que interessou a presente pesquisa. As concepções de Bauman mostraram ser extremamente ricas se contempladas com a devida mediação. Os modelos construídos a partir das metáforas do "legislador" e do "intérprete" foram tomados como parâmetros, balizas interpretativas e, nessa perspectiva, contribuíram para a compreensão de aspectos ligados a condição dos intelectuais na contemporaneidade. Tratadas de maneira antinômica, dificilmente poderiam resultar em análises capazes de propiciar avaliações de situações concretas.

Adotar os princípios normativos da proposta interpretativa de Bauman significou pensar a comunidade docente pertencente à Faculdade de Filosofia como parte integrante do processo de transição da história intelectual no ocidente: contemplada pela perspectiva inaugurada pelos "legisladores" modernos e atualizada por intermédio das contradições estabelecidas pela modernidade radicalizada e pelo novo papel desempenhado pelos intelectuais "intérpretes". Destarte, os parâmetros interpretativos sugeridos por Bauman, permitiram contextualizar a comunidade docente no interior desse intrincado processo na história ocidental de declínio do intelectual "legislador" e do predomínio crescente dos "intérpretes". Nesse sentido, a comunidade docente forjada entre a ditadura e a democracia estaria igualmente localizada entre o refluxo da tradição legisladora e a ascensão dos intelectuais "intérpretes" no mundo ocidental.

A Faculdade de Filosofia da USP constitui para a memória coletiva da comunidade docente um espaço de liberdade. Nesse sentido, uma das hipóteses construídas em relação a seus membros, sustenta que o fato de serem intelectuais intrinsecamente pertencentes à carreira pública, possibilitou a escolha de caminhos autônomos. Em um contexto cada vez mais propício para o exercício do papel de "intérpretes", muitos professores insistiram em exercer atividades pautadas pelos

\footnotetext{
${ }^{165}$ Para Bauman, o intelectual tradicional, ou legislador, deve ser pensado enquanto aquele que se dirige ao espaço público: "O que os unia? O que era reconhecido, à época, algo de que tinham consciência, e que foi poderosamente reforçado pela memória viva de uma época posterior? Eu sugiro que o único elemento unificador, mas poderoso e decisivo, não deve ser procurado no que - ou mesmo em como - os philosophes professavam, mas no propósito e na importância do próprio ato de professar". BAUMAN, Z. Op. cit., p.44.
} 
parâmetros modernos, atuando como intelectuais "legisladores". A universidade pública teria oferecido, assim, condições para que seus docentes escolhessem desempenhar as funções que melhor atendiam a suas expectativas diante da redemocratização política; o que, não poucas vezes, possibilitou a construção de pontes entre atribuições diversas.

Ao fazerem referência à condição de autonomia construída pela carreira universitária, as memórias docentes deram contorno a diferentes modos de resistência em relação a interesses obtusos praticados pelo próprio Estado, bem como a perspectivas de teor patrimonialista e de setores imediatistas, tais como os de mercado. Pois, contraditoriamente, a posição dos docentes enquanto funcionários públicos lhes garantiu uma autonomia relativa, mas consistente, que, à maneira moderna, conferiu ao grupo a segurança necessária para o estabelecimento de pesquisas independentes e a apresentação de avaliações soberanas.

Essa mesma condição de funcionários públicos, que havia sido problemática durante o regime militar, seria galvanizada no período democrático, permitindo que as universidades estaduais e federais e seus docentes, de uma maneira geral, tivessem condições de pavimentar carreiras sólidas e capazes de resistir às constantes ameaças contra o interesse público. Essa perspectiva foi sintetizada pela crítica elaborada por Ianni ao processo que chamou de "industrialização da pesquisa", ou seja, aquele que transforma os intelectuais em especialistas ou técnicos que se preparam para dar respostas a demandas externas e de mercado.

As preocupações de Octávio Ianni em relação à universidade pública foram reveladas no discurso proferido na cerimônia em que lhe foi concedido o título de professor emérito, em 28 de junho de 1997, no qual falou sobre "As Ciências Sociais na Época da globalização" ${ }^{\text {,66 }}$. A universidade foi contemplada em sua fala, intitulada $O$ compromisso com a universidade, como um local fundamental para a sociedade contemporânea. "O que está em causa é a universidade. Mais uma vez cabe repensar a universidade", destacava Ianni. Ao longo de sua palestra apresentou três ameaças contra a universidade pública que deveriam ser enfrentadas. Primeiramente, tratou das pressões que estariam impelindo a universidade para "ajustar-se ao ethos tecnocrático imposto de todas as formas pelo neoliberalismo". "Os requisitos da produtividade e da "qualidade total' estão sendo impostos à universidade, como se esta fosse ou devesse transformarse em uma fábrica de mercadorias", completou o autor. Em segundo lugar, a

${ }^{166}$ IANNI, O. O Compromisso com a Universidade. São Paulo: Humanitas/FFLCH-USP, 1999. 
universidade estaria sendo desafiada para preservar e desenvolver seu compromisso com a pesquisa original e o diálogo aberto com as mais diversas correntes de pensamento. Segundo Ianni, "além da formação de profissionais, técnicos, professores e pesquisadores, pode contribuir para o desenvolvimento das ciências, da filosofia e das artes. É assim que pode preservar e enriquecer o ethos humanístico, que continua a ser sua missão fundamental". Por fim, a universidade estaria sendo provocada a abrir-se para a universalidade: "Mais do que nunca, cabe reconhecer que as transformações que estão acontecendo no mundo, nessa altura do século XX, abrem novos desafios e novas perspectivas para o ensino e a pesquisa, a razão e a imaginação", concluía o autor.

As posições de Ianni, de algum modo, sintetizavam no final dos anos 1990, o sentimento de toda uma geração de professores universitários em relação à importância da universidade pública no Brasil. Não obstante, refletia as tensões provocadas pelas contradições entre interesses públicos e privados, além de fazer referência às pressões emanadas a partir das novas demandas sociais que passavam a bater à porta da democracia política. Diante das profundas contradições econômicas e das desigualdades sociais, Ianni foi enfático quanto à responsabilidade da universidade de "desenvolver o ethos humanístico, do qual toda sociedade carece e sem o qual padece"167.

Em sintonia com as proposições de Ianni, a defesa da universidade pública é um dos traços constitutivos mais presentes na memória coletiva da comunidade docente pesquisada. As disputas travadas entre as memórias individuais resultaram em uma negociação na qual o ensino público e a preservação da autonomia docente constituem balizas que conferem identidade ao grupo pertencente à Faculdade de Filosofia. Além disso, foi possível atestar a preocupação com a produção de conhecimentos regulados pelo compromisso com pautas humanistas e a obrigação, peculiar aos intelectuais "legisladores", de contribuir para a construção e aprofundamento do espaço público.

Um dos pontos de intersecção mais perceptíveis entre as memórias individuais corresponde ao compromisso com a elaboração do conhecimento crítico. Por maiores que sejam as críticas dos docentes entrevistados a respeito do processo de institucionalização da carreira docente e dos limites e ameaças externas e internas de instrumentalização das pesquisas, a Faculdade de Filosofia foi contextualizada pela memória coletiva como um espaço de liberdade, atuação autônoma e produção de pesquisas independentes.

${ }^{167}$ Idem, p. 16. 
Para a comunidade pesquisada, a carreira docente na Faculdade de Filosofia, representou uma oportunidade de dar continuidade a um trabalho intelectual integrado a uma agenda pública e atento à democratização política. $\mathrm{O}$ regime de dedicação integral à docência e à pesquisa valorizou o trabalho desenvolvido professores, garantindo o amadurecimento de hipóteses e a sedimentação de projetos de longa duração, possíveis apenas em um contexto de autonomia universitária.

As trajetórias de vida docente, evidenciadas pela pesquisa, possibilitaram o escrutínio de uma temporalidade peculiar que problematiza a condição dos intelectuais na passagem da ditadura para democracia política. Pensadas em seu conjunto, as histórias acadêmicas apresentaram professores preocupados em reorientar o seu papel profissional diante das transformações políticas ocorridas no país. Para tanto, foi preciso vencer as resistências em relação à própria condição da carreira pública e reaprender a trabalhar em uma universidade livre do controle autoritário dos militares. Afinal, no período ditatorial os intelectuais críticos e combatentes haviam sido expulsos da universidade por serem funcionários públicos que "atuavam contra os interesses do Estado". Em pleno processo de reconstrução democrática foi preciso requalificar a via institucional e consolidar novos princípios para a carreira universitária. Essa, provavelmente, foi uma das tarefas mais difíceis enfrentadas por essa comunidade: a de reconfigurar o papel dos docentes diante da sociedade e do Estado democrático em formação.

Como docentes forjados entre a hegemonia das referências culturais modernas e o avanço de suas contradições presentes em uma modernidade cada vez mais radicalizada, a profissionalização da carreira fez também parte do processo de descoberta da universidade pública como abrigo, morada, ethos a ser (re)construído e defendido. Na democracia, contudo, a condição de funcionário público ganhou uma nova conotação, mais segura em vários aspectos, embora não menos ameaçada por interesses de outra ordem, persistentes na história da sociedade brasileira e, nem sempre explícitos, nas várias facetas apresentadas pelo patrimonialismo ${ }^{168}$. Ao defender o fortalecimento da autonomia universitária, a comunidade docente reuniria forças para enfrentar os novos desafios apresentados pelo processo de redemocratização.

Maria Hermínia Tavares de Almeida, docente titular do Departamento de Ciência Política da FFLCH-USP, estudou a participação política dos intelectuais nos anos 1970.

${ }^{168}$ SORJ, B. A nova sociedade brasileira. Rio de Janeiro: Jorge Zahar, 2006. 
Na obra Tomando partido, formando opinião - cientistas sociais, imprensa e política, desenvolveu o argumento de que houve "um processo de transformação dos grupos intelectuais em atores da transição”. Quando, nesse sentido, o envolvimento com a imprensa e o contato com um público mais amplo do que o acadêmico começava a ser possível em plena ditadura:

Em 1974, como parte da virada do oposicionismo agressivo que o partido empreendia, sua direção buscou aproximação com os intelectuais. Os artigos de Opinião fizeram mais do que tornar conhecidos seus autores, pavimentando o caminho de alguns rumo à vida política. Eles foram importantes para a construção pública dos intelectuais acadêmicos ${ }^{169}$.

A comunidade docente foi forjada em um contexto de mudanças na cultura universitária e de uma longa transição política. Ao ímpeto de gerar problemáticas e elaborar respostas aos graves problemas sociais brasileiros, combinava-se o desejo de transformar a realidade política e social do país. O desafio de romper com o autoritarismo e construir uma democracia colocou os intelectuais na posição de vencer a inércia imposta pelas cátedras e de procurar estabelecer um diálogo franco entre a universidade e a sociedade. Estava em jogo a formulação de uma nova cultura política que dependia de propostas para a renovação da universidade e da educação brasileira como um todo.

Alfredo Bosi, no prefácio escrito para o livro Ideologia da Cultura Brasileira do Prof. Carlos Guilherme Mota, - originalmente escrito como tese de livre-docência apresentada à mesma Faculdade, procurou identificar os principais eixos e alterações no plano cultural no início dos anos 1970:

A partir de 70, o nosso pensamento social, a imagem da História que está se recompondo, tende a perder aquela confiança no reformismo puramente verbal e no saber que permeava as visões "integrativas" de anos anteriores. Pensa-se menos no quadro das funções em equilíbrio e mais em um espaço plural onde se impôs a hegemonia de classes e grupos (...) A teoria da cultura tem retomado coerentemente os princípios fundamentais da dialética hegeliana relida mediante Lukács, Gramsci, Horkheimer e Adorno, e deixando para trás os dualismos fáceis como sua fácil passagem do mal ao bem, isto é, do tradicional ao moderno, do religioso ao profano, do artesanal ao

\footnotetext{
${ }^{169}$ TAVARES DE ALMEIDA, M. H. Tomando partido, formando opinião - cientistas sociais, imprensa e política.Op. cit., p.26.
} 
mecânico; tem mostrado, antes, o convívio das contradições dentro de um sistema amplo, inclusivo, neocolonial, capitalista ${ }^{170}$.

No caso específico do Brasil, a longa transição política estimulou a participação e incitou os intelectuais a novos modos de participação. Interpretar a sociedade e suas diferentes formas de produção cultural, econômica e política, significava, em última instância, propor sugestões para a reestruturação do Estado autoritário e refletir sobre as principais características dos embates sociais e das contradições entre o mundo do trabalho e o capital. Fundamentalmente, os docentes vislumbravam uma reconfiguração do espaço público: importava desenvolver pesquisas e consolidar novas concepções interpretativas capazes de contribuir na construção de uma nova agenda política para o país.

Em resumo, o ineditismo das questões impostas durante a fase de redemocratização forjou uma comunidade que sintetizou aspectos próprios da transição, resultando uma combinação peculiar elaborada em um contexto de demandas que exigia novos projetos e a participação pública dos intelectuais. Em entrevista a Heloisa Buarque de Hollanda, o escritor Julio Cesar Monteiro Martins afirmou:

Se os anos 60 foram anos de ação, os anos 70 foram de reflexão sobre esta ação, de autocrítica e de reformulação de projetos já então obsoletos, através do acréscimo de novos dados e da constatação da complexidade das relações históricas, antes nem mesmo pressentidas $^{171}$.

Situada entre duas culturas universitárias e forjada no descompasso entre modernidade e modernidade radicalizada, a comunidade docente viveu intensamente as discussões em torno do papel da universidade e dos intelectuais, em um período no qual se questionava quais seriam as suas principais responsabilidades e, ao mesmo tempo, os limites de sua profissão no país e em todo hemisfério ocidental.

A condição segura e a estabilidade financeira proporcionada pela função pública de carreira, uma vez observadas a partir das especificidades do contexto de transição, contrastavam com a histórica inexistência de instituições democráticas consolidadas e da falta de serviços públicos consistentes disponibilizados à população brasileira. Nesse

${ }^{170}$ BOSI, A. "Prefácio". In: MOTA, C. G. Ideologia da Cultura Brasileira. São Paulo: Ática, 1977, p. VIII.

${ }^{171}$ GASPARI, E., VENTURA, Z., \& HOLLANDA, H. B. de. Cultura em trânsito 70/80: da repressão à abertura. Op. cit., p. 153. 
sentido, talvez o maior desafio infligido à comunidade docente tenha sido enfrentar as contradições próprias de uma democracia política em fase de amadurecimento e as graves desigualdades sociais, a permanência de instituições e valores elaborados no contexto autoritário e o problema da precariedade dos direitos civis. Como ressaltou José Murilo de Carvalho, "pode-se dizer que, dos direitos que compõem a cidadania, no Brasil são ainda os civis que apresentam as maiores deficiências em termos de seu conhecimento, extensão e garantias" ${ }^{\text {172 }}$.

As entrevistas de história oral de vida acadêmica permitiram pensar a carreira universitária pública em uma perspectiva problematizadora. $\mathrm{O}$ acesso às contradições presentes no plano cotidiano possibilitaram compreender como os intelectuais refletiram sobre a sua própria condição profissional e as responsabilidades dela decorrentes. As narrativas possibilitaram ainda o contato direto com sujeitos históricos concretos e a identificação de como se costuraram as relações intersubjetivas no interior da comunidade $^{173}$.

Os dramas, as frustrações, as derrotas e as conquistas dessa comunidade docente, observados a partir do ângulo da história oral de vida, possibilitaram avaliar o trabalho intelectual em um período de transição política e marcado por intensos debates travados em torno dos limites e das potencialidades da democracia. Nesse sentido, mediante a perspectiva sugerida por Löwy, a pesquisa procurou investigar a condição transitória dos docentes - situados entre duas culturas universitárias e posicionados no descompasso da perspectiva moderna para a modernidade radicalizada - como criadores de produtos ideológico-culturais representativos desse contexto histórico:

Que é um intelectual? Trata-se sem dúvida de um ser bizarro e difícil de classificar. A primeira evidência é que o intelectual pode ser recrutado em todas as classes e camadas da sociedade: pode ser aristocrata (Tolstoi), industrial (Owen), professor (Hegel) ou artesão (Proudhon). Em outros termos: os intelectuais não são uma classe, mas uma categoria social; não se definem por seu lugar no processo de produção, mas por sua relação com as instâncias extra-econômicas da estrutura social; do mesmo modo que os burocratas e os militares se definem em sua relação com o político, os intelectuais situam-se por sua relação com a estrutura ideológica. Quer dizer: os intelectuais são uma categoria social definida por seu papel ideológico: eles são os

\footnotetext{
${ }^{172}$ CARVALO, J. M. Cidadania no Brasil: o longo caminho. Rio de Janeiro: Civilização Brasileira, 2006, p. 210 .

${ }_{173}$ Utiliza-se o conceito de intersubjetividade de acordo com os pressupostos estabelecidos por Luiza Passerini e explicitado no capítulo 1. Ver: PASSERINI, L. A memória entre política e emoção. Op. cit..
} 
produtores diretos da esfera ideológica, os criadores de produtos ideológico-culturais. Ocupam, então, um lugar específico naquilo que se poderia chamar de processo de produção ideológica ${ }^{174}$.

Ao defenderem a pesquisa e o ensino público, evidenciados no discurso de Ianni, os docentes entrevistados situam-se na condição de produtores modernos em um contexto de modernidade radicalizada. A presença na memória coletiva de referências ao papel público dos intelectuais e, particularmente, em relação à missão formadora e crítica da Faculdade de Filosofia, atesta a condição como elaboradores de conhecimento humanista e de formuladores de reflexões sobre o espaço público.

As histórias de vida acadêmica revelaram, enfim, que os intelectuais investigados se profissionalizaram, mas não perderam a capacidade de produzir conhecimentos originais, autônomos e de defenderem posições políticas e projetos de futuro; como também, conservaram a disposição em debater e propor utopias. Nesse caso, a opção pela via institucional e acadêmica precisa ser compreendida como chave para novos projetos intelectuais e condições originais de atuação. Como parte integrante de uma sociedade em transformação, os intelectuais tiveram liberdade de escolher pela condição de "intérprete" ou atuar como "legisladores" na (re)construção do espaço público e na (re)organização das instituições democráticas que tinham sido destruídas e, ainda, na formulação de outras que nunca tinham sequer existido.

\subsection{Memória coletiva e compromisso público.}

As entrevistas realizadas com a comunidade docente pertencente à Faculdade de Filosofia problematizaram hipóteses que pareciam plenamente resolvidas pelos estudos históricos e sociológicos ${ }^{175}$. Paradoxalmente, a profissionalização da carreira docente nas universidades públicas iniciada em pleno regime militar havia contribuído decisivamente para que pensadores independentes pudessem ter condições materiais

\footnotetext{
${ }^{174}$ LÖWY, M.. Para uma sociologia dos intelectuais revolucionários. São Paulo: LECH, 1979, p.1.

${ }^{175}$ É importante frisar que Russel Jacoby reconhece que sua análise não abrange os países africanos e, certamente, nem os asiáticos e latino-americanos. Está circunscrita aos limites da América do Norte e da Europa ocidental, onde "os intelectuais nem estão em perigo nem são perigosos. Apenas uns poucos conservadores continuam a atacar os intelectuais como subversivos. No cômputo geral, os intelectuais não parecem propriamente revolucionários ou marginais". JACOBY, R. O fim da utopia. Op. cit., p.151.
} 
essenciais - inclusive financeira -, para o desenvolvimento de pesquisas e a consolidação de uma reflexão autônoma no interior do ensino superior público e gratuito.

A cultura universitária sofreu mudanças drásticas com o avanço dos parâmetros norte-americanos e o fim das Faculdades de Filosofia Ciências e Letras no Brasil a partir da promulgação da Lei 5549/68. No entanto, o fato de os docentes entrevistados terem se formado e atuado como professores e pesquisadores pautados por uma cultura acadêmica em transição - entre aquela produzida no contexto da Maria Antônia e a posteriormente desenvolvida na FFLCH-USP - foi determinante para o cultivo de um ethos de resistência. Não fosse a efetiva instauração dos concursos públicos no início dos anos 1980, o processo de institucionalização poderia ter liquidado com a produção de saberes autônomos e críticos em relação às contradições que fazem parte da constituição íntima da sociedade brasileira.

Trata-se, portanto, de uma comunidade docente empoderada por uma tradição moderna e atuante em um contexto de radicalização de suas contradições. As incertezas impostas pela modernidade radicalizada contrastam com as memórias de uma comunidade docente que resiste em defender princípios incômodos, como os da defesa do ensino público e do compromisso com a formação crítica.

Isso não significa que os docentes estejam plenamente satisfeitos com o processo de profissionalização ocorrido na FFLCH-USP. Os professores reconheceram em suas narrativas a necessidade de aproximar a universidade da sociedade, mas não concordaram com a introdução paulatina de práticas baseadas na razão instrumental. Denunciaram ainda que o fim da autonomia pode levar a universidade pública a se tornar uma simples "prestadora de serviços" ao atender de maneira imediatista e sem critérios às constantes demandas da comunidade.

As entrevistas trouxeram à tona a questão da autonomia universitária como a pedra de toque que mobiliza a comunidade docente e, em torno da qual, se pauta o papel da universidade pública e de seus professores. "A universidade tem que interferir e participar do conjunto da sociedade, ela não pode ficar isolada. Inclusive porque é a sociedade que paga o nosso trabalho e precisamos retribuir", afirmou Abdala Jr. Para tratar da responsabilidade dos docentes que atuam em universidades públicas, este recorreu ainda à atuação de Edward Said como professor universitário e intelectual combativo: 
O intelectual não pode ficar fechado no seu gabinete, com condecorações, etc. Não, ele tem que interferir no dia-a-dia. $\mathrm{O}$ grande exemplo que vejo é de um teórico que faleceu já há uns cinco anos, o Edward Said. Said era professor de Literatura e catedrático em Literatura Comparada da Universidade de Columbia. Como professor ele publicava textos de literatura comparada, mas, por outro lado, ele semanalmente soltava um artigo para o mundo árabe. Quer dizer, ele desempenhava assim o seu papel de cidadão, de intervenção, sobretudo em relação à causa palestina. Como palestino, entre gregos e troianos, ele tinha as posições dele. Ele inclusive era amigo de judeus e escreveu livros em parceria com quem também tinha propostas semelhantes e defendia um estado laico e democrático para a Palestina. Claro que a perspectiva política de Said aflorava mesmo no trabalho com a Literatura Comparada. Por isso vejo nele um modelo de intelectual participante, porque atuava em várias frentes, inclusive, na reflexão. Isso faz muita falta. Esse é um espaço que nós estamos perdendo continuamente. A FFLCH, sobretudo, pode ser mais ativa nisso para não ficar contemplando ruínas.

Citado em algumas entrevistas pelos docentes, Said representa para a comunidade estudada um exemplo de intelectual público que diz muito a respeito da condição e dos desafios impostos à sua prática cotidiana. Sendo também um professor universitário, o trabalho de Said sempre foi lembrado por ter contribuído em duas frentes igualmente importantes, a reflexão acadêmica e a intervenção pública como intelectual e cidadão. Além da reflexão em torno da literatura comparada ele atuava diretamente na produção de textos políticos endereçados ao mundo árabe, estabelecendo um diálogo entre Ocidente e Oriente.

A condição de intelectuais forjados entre a ditadura e a democracia permitiu aos docentes da Faculdade de Filosofia, mesmo em meio à expropriação de espaços e diante do refluxo da brasilidade revolucionária, investir em novas possibilidades de atuação no regime democrático e de diálogo com a sociedade civil. Para Abdala Jr.:

O intelectual hoje está todo encolhido, isso é uma evidência. Há toda uma conjuntura que levou a isso. De um lado você tem essa mídia que tem os seus critérios de massificação e de outro a ascensão do capitalismo financeiro e todos os projetos de desregulamentação. Por parte da intelectualidade, um sentimento de melancolia. Os intelectuais que poderiam ser tratados como mais antigos, se vêem mergulhados em uma atmosfera de ruínas, de melancolia. Isto é, não possuem aquele horizonte de futuro, que me parece fundamental. Nesse sentido, parece-me imprescindível recuperar a ideia de sistemas e a concepção de totalidade. Não a totalidade como um sistema fechado, mas pensada como sistemas abertos, em processo em um mundo em processo. É preciso pensar em espaço-tempo, 
temporalidades, espaço-tempo processuais e, nesse sentido, dentro do nosso âmbito acadêmico aqui na USP, procurar interferir na vida sociocultural.

Abdala defendeu que a atuação pública dos intelectuais depende de investimentos constantes em princípios como o da totalidade, de horizonte de futuro, e de utopia, ou seja, na valorização de raízes incrustadas na brasilidade revolucionária. Diante do processo de institucionalização, como ressaltou Abdala, coube a esses intelectuais se apropriarem de ferramentas dentro do âmbito acadêmico que poderiam de alguma maneira interferir na vida sociocultural brasileira.

Para a memória coletiva docente, o compromisso para com a sociedade deve ser observado nas atividades desenvolvidas no interior da universidade pública, visando sistematizar conhecimentos que pudessem contribuir para ações e projetos públicos. Desse modo, em se tratando de uma comunidade docente que compartilha o desejo de interferir no espaço público, a criação e o desenvolvimento de centros de pesquisa passaram a ser considerados uma maneira de reinventar a institucionalização da carreira acadêmica e garantir o estabelecimento de um diálogo com o processo de consolidação da democracia política.

Uma das formas encontradas pelos docentes para inserir a FFLCH-USP no debate em torno da (re)introdução da questão democrática foi a criação e o desenvolvimento de núcleos de estudos e pesquisas. Expressão dos novos tempos de universidade administrada, paradoxalmente os núcleos ganharam condições de implementar pesquisas e desenvolver problemáticas públicas porque dirigidos por intelectuais avessos à subordinação da universidade à interesses particulares. Nos termos propostos por Bauman, portanto, os projetos universitários desenvolvidos pela comunidade docente podem ser interpretados como a expressão mais acabada do modo como compromissos de relevância pública foram assumidos em condições adversas ao trabalho do intelectual enquanto "legislador".

Ao recuperar o estudo e a reflexão sobre questões públicas e colocar em pauta os vínculos entre o cotidiano e a totalidade macro-histórica, os docentes reivindicam o papel de intelectuais que resistem às pressões da modernidade radicalizada e reinventam a possibilidade de reconstruir um diálogo mediado e não imediatista com a sociedade. Partindo das considerações formuladas por Löwy em relação ao papel dos intelectuais, procurou-se investigar os meandros e fímbrias do trabalho acadêmico desenvolvido 
pelos docentes da Faculdade de Filosofia da USP, tais como a criação de disciplinas, a concepção e desenvolvimento de linhas e núcleos de pesquisa, ou seja, o seu papel enquanto produtores culturais independentes e engajados ${ }^{176}$.

A consolidação dos núcleos de pesquisa na Universidade de São Paulo a partir do final dos anos 1980 e, principalmente, daqueles ligados à Faculdade de Filosofia, representou o esforço dos professores em sanar os limites curriculares de disciplinas que já não davam conta dos compromissos da universidade com a sociedade. Os novos anseios democráticos gestados no país impulsionaram os docentes a elaborar propostas de formação que contemplassem aspectos marginalizados nos cursos regulares: a questão indígena, o papel da mulher, o neoliberalismo, a globalização, o negro na sociedade brasileira, os movimentos e partidos políticos de esquerda, a violência, a intolerância, a música popular brasileira, os processos de urbanização, o meio ambiente, o futebol, a construção da cidadania, os diálogos estabelecidos entre a literatura brasileira e aquelas produzidas pelos países africanos de língua portuguesa, entre tantos outros exemplos. As pesquisas realizadas nos núcleos, dessa forma, passaram a oferecer dados originais que alimentavam as disciplinas existentes ou, ainda, possibilitavam o surgimento de novas, contribuindo para uma formação crítica e atenta às contradições da sociedade brasileira.

Sendo assim, coube examinar mais detidamente e a título de exemplificação, alguns dos projetos coordenados e desenvolvidos pelos professores investigados durante o contexto de refluxo da brasilidade revolucionária e de consolidação da democracia política. A saber, as pesquisas e orientações desenvolvidas por Benjamin Abdala Jr. no Centro de Estudos de Literaturas e Culturas de Língua Portuguesa (CEP), por Zilda Iokoi no Núcleo de Estudos das Diversidades Intolerâncias e Conflitos (Diversitas), de Francisco de Oliveira no Centro de Estudos dos Direitos da Cidadania (CENEDIC), por Eunice Durham e José Álvaro Moisés no Núcleo de Estudos em Políticas Públicas (NUPPs), por Sérgio Adorno no Núcleo de Estudos da Violência (NEV) e por Ana Fani Alessandri Carlos no Grupo de Estudos sobre São Paulo (GESP-LABUR).

Para Alessandri Carlos o Grupo de Estudos sobre São Paulo (GESP) lotado no Departamento de Geografia da FFLCH-USP, conhecido também como grupo de

\footnotetext{
${ }^{176}$ Para Löwy "Os intelectuais, por seu distanciamento da produção material e, sobretudo, pela própria natureza de sua categoria social (definida por seu papel ideológico), são o grupo da sociedade para o qual as ideologias e os valores tem a maior importância e o mais decidido peso". Ver: LÖWY, M.. Para uma sociologia dos intelectuais revolucionários. Op. cit., p.7.
} 
Geografia Crítica Radical, foi criado com o objetivo de responder a algumas perguntas, por exemplo: "Como o capital financeiro se realiza na metrópole? Como as resistências e lutas acontecem? Como se dá a privação do mundo na metrópole?’. Nas palavras de Alessandri Carlos:

Então tem um monte de coisas importantes acontecendo no meio de toda essa burocracia, o NAP, o GESP e, isso tudo, graças ao nosso lugar na Faculdade de Filosofia. Na época fui conversar com a diretora que era a Sandra Nitrini e propus a ela que a Faculdade bancasse um site nosso e que ele tivesse uma editora eletrônica. A diretoria aprovou essa proposta e nós fizemos o site e uma editora eletrônica que é a FFLCH Edições. E nessa editora nós temos publicadas as teses e alguns livros feitos por esse grupo dentro da linha teórico-metodológica marxista-lefebvriana.

O GESP, também ligado ao Laboratório de Geografia Urbana do Departamento de Geografia da FFLCH-USP (LABUR), levou à criação de um Núcleo de Apoio à Pesquisa (NAP) chamado "Urbanização e Mundialização" e que conta com a parceria do Instituto de Arquitetura e Urbanismo da USP de São Carlos. Para Ana Fani, a institucionalização e viabilização dessas pesquisas realizadas em parceria tem a capacidade de revitalizar o debate acadêmico e contribuir para uma interpretação crítica a respeito das mudanças espaciais nas metrópoles em um contexto definido como mundializado:

Então esse é o trabalho que a gente faz em um laboratório e que é completamente diferente da institucionalização. $\mathrm{O}$ que quer dizer o seguinte: a USP caminha numa trajetória, mas na FFLCH há espaços para a gente fazer outras coisas no interior da institucionalização. $\mathrm{O}$ Laboratório de Geografia Urbana é importante, a possibilidade de termos grupos de estudos é fundamental, o NAP abre uma perspectiva importante na contramão das tendências produtivistas posta pela universidade neoliberal.

As considerações apresentadas por Alessandri Carlos quanto à possibilidade de atuar de maneira autônoma no interior da institucionalização, exemplificam a disposição dos docentes pertencentes à comunidade pesquisada em trabalhar visando contribuir para a formação de políticas públicas destinadas ao bem comum. Ao estabelecer um diálogo direto com a cidade de São Paulo, as pesquisas orientadas pela professora oferecem ferramentas teóricas para compreender o desenvolvimento do espaço urbano onde a universidade está inserida. Além disso, alguns estudos avaliam as relações entre 
os indivíduos e a cidade em um contexto de diminuição dos espaços onde os cidadãos podem se encontrar. A análise de Alessandri Carlos representa, assim, um alerta em relação aos projetos urbanos orquestrados pelo capital financeiro em São Paulo:

Então na minha tese de livre docência construo a ideia de que o que caracteriza a modernidade é uma nova relação espaço-tempo, onde o tempo é cada vez mais efêmero e, o espaço, se torna amnésico. Essa relação espaço-tempo no meu ponto de vista caracteriza esse período da modernidade que nós estamos vivendo, e é isso que eu pude analisar na metrópole de São Paulo. Então nesse movimento de passagem fui ver como o capital financeiro se realiza hoje, não só na ciranda financeira, mas fundamentalmente através da produção de um espaço real e concreto, que é a produção de um eixo comercial e empresarial na cidade de São Paulo. Este é o eixo que vai da Av. Faria Lima e chega à Av. Luiz Carlos Berrini. É importante perceber que esse movimento articula as frações do capital financeiro, industrial e comercial, porque a indústria não morreu, aliás, a indústria da construção civil está mais forte do que nunca nesse momento. Então, como essas três frações de capitais se uniram - criando uma estratégia associada ao espaço patrimonialista brasileiro -, passaram a construir um espaço contra o social, ou seja, trata-se de uma operação urbana que se revela contra a população que mora nessas áreas.

Benjamim Abdala Júnior, professor de Literatura Portuguesa e de Literaturas Africanas de Língua Portuguesa, tornou-se diretor do Centro de Estudos de Literaturas e Culturas de Língua Portuguesa da FFLCH-USP em 1997. Segundo Abdala Jr., o núcleo realiza estudos comparados entre literaturas de língua portuguesa (Brasil, África e Portugal) a partir de suas bases sociais. Em sua livre docência intitulada Imagem (n/a/ç/ã/o) política: Literaturas de língua portuguesa, hoje: a dialética do engajamento, defendida em 1988, demonstrou justamente “como a imagi(nação) política não só reapropria traços definidores da nacionalidade, mas também os reinventa em função de uma perspectiva política libertária" ${ }^{\text {177. }}$.

Desde os estudos sobre Graciliano Ramos até os mais recentes realizados em relação a autores africanos de língua portuguesa, como Pepetela ${ }^{178}$, a relação entre os intelectuais com as atividades políticas e públicas sempre foram centrais em suas pesquisas. O estudo comparado de escritores africanos de língua portuguesa com

\footnotetext{
${ }^{177}$ A tese de livre-docência foi publicada com o título: Literatura: História e Política - Literaturas de Língua Portuguesa no século XX. São Paulo: Ática, 1988.

${ }_{178}$ Artur Carlos Maurício Pestana dos Santos (Benguela, 29 de Outubro de 1941), conhecido pelo pseudônimo de Pepetela, é um escritor angolano.
} 
escritores brasileiros procura evidenciar as confluências político-ideológicas entre as partes:

\begin{abstract}
A bem da verdade, tudo isso acontecia fora do horizonte da ditadura, nós estamos falando já dos anos 1980 e 1990, época na qual defendi a criação de uma nova área disciplinar, os Estudos Comparados de Língua Portuguesa. (...) Juntamente com a Prof. ${ }^{a}$ Maria Aparecida Santilli, constituímos a disciplina de Literaturas Africanas em língua portuguesa em nível da graduação. Ela foi a primeira a estudar as literaturas africanas, inclusive em nível nacional, e eu a acompanhei. Isso significou para mim uma extensão, porque eu trabalhava com uma literatura de ênfase política no Brasil e em Portugal, quando cheguei também aos autores africanos. As literaturas africanas foram formadas nessa perspectiva mais política, porque para eles não se tratava apenas de constituir uma literatura nacional, mas também de lutar pela independência do próprio país. Essas literaturas se formaram basicamente no pós-guerra, sob a ambiência da Guerra Fria. Os africanos tinham simbolicamente em Portugal a pátria, mas eles se identificavam com a mátria africana, a figura da mulher africana, a terra africana, a mátria.
\end{abstract}

A despeito do avanço da modernidade radicalizada e do refluxo das concepções próprias à brasilidade revolucionária, Abdala resiste em manter "na ordem do dia" questões relativas à sua própria história intelectual e de toda a comunidade docente a que pertence, ao investigar questões utópicas e revolucionárias através da literatura comparada.

Sérgio Adorno trabalha como coordenador científico do Núcleo de Estudos da Violência (NEV-USP) desde 1990. Esse núcleo foi criado em 1987 e, desde então, está vinculado à pró-reitoria de Pesquisa da USP. A sua origem está ligada aos trabalhos realizados pela Comissão Teotônio Vilela criada em 1982 pelo então senador Severo Gomes para apurar crimes contra os direitos humanos. Em 1985, o Prof. Dr. Paulo Sérgio Pinheiro, um dos seus membros, considerou que deveria fazer parte das atribuições daquela entidade a realização de pesquisas na área de direitos humanos:

Nesse período o Prof. Paulo Sérgio Pinheiro propôs a criação do Núcleo de Estudos da Violência (NEV-USP) e, ao aceitar, definitivamente me enraizei na universidade. Fiz a minha carreira inteira aqui. Apesar dos problemas que eventualmente a gente tem, gosto muito da universidade porque ela ainda é um lugar privilegiado para trabalhar em termos de autonomia e liberdade. É difícil encontrar um ambiente de trabalho onde existam tantas possibilidades de desenvolvimento desde que prestando contas. Nós não temos nada contra prestar contas. Mas a questão principal é que nosso trabalho é 
desenvolvido com autonomia já que o meu chefe de departamento não diz o que eu tenho que fazer. É claro que existe o compromisso das aulas, mas nós sempre tivemos muita liberdade para montar os programas dos cursos.

O núcleo se comprometeu em realizar pesquisas que objetivaram compreender a permanência de práticas autoritárias durante a construção da democracia. Além disso, destacaram-se estudos que avaliaram o funcionamento do sistema judiciário no país, outros sobre práticas judiciais, além daqueles que se dedicaram ao exame sobre índices de impunidade e seu impacto na democracia. Houve, ainda, pesquisas que investigaram a confiança política na democracia e suas relações com a punição e o policiamento desejado pela sociedade, bem como sobre a atuação dos agentes de Estado no combate à criminalidade. $\mathrm{O}$ enraizamento das atividades desenvolvidas pelo NEV na universidade é representativo desse novo momento vivido pela profissionalização da carreira acadêmica. As pesquisas desenvolvidas pelo NEV evidenciam, portanto, o diálogo inaugurado pelos intelectuais pertencentes à comunidade estudada com a estruturação do regime democrático e as responsabilidades dele decorrentes.

Em uma pesquisa que se proponha a escrever sobre a história dos núcleos de pesquisa da USP, o Núcleo de Pesquisas do Ensino Superior (NUPES), atual NUPPs, teria presença destacada pela dimensão que seus trabalhos atingiram ao longo do processo de institucionalização da universidade e no desenvolvimento de políticas públicas para a educação nacional ${ }^{179}$. Fundado por Simon Schwartzman e Eunice Durham, o NUPPs foi criado com o objetivo de trabalhar diretamente vinculado à reitoria da USP, colaborando para o desenvolvimento de projetos para a reestruturação da própria universidade e do ensino superior como um todo:

Então o NUPES fez muita pesquisa. Nós começamos com uma pesquisa que foi muito interessante, organizada pelo Simon Schwartzman e o cientista político chileno José Joaquín Brunner, que

\footnotetext{
179 Segundo Barreyro e Rothen, o núcleo já foi alvo de estudos importantes: “as políticas públicas da educação superior brasileira a partir da década de 1990 receberam a direta influência do Núcleo de Estudos e Pesquisas sobre o Ensino Superior (NUPES). Os estudos de Palharini (1998), Silva Júnior (2007), Grello (2008) e Hey (2008) mostram que o Núcleo teve papel predominante nas políticas para Educação Superior no Governo Fernando Collor de Melo e no Governo Fernando Henrique Cardoso, e que as suas idéias ainda estão presentes nas práticas do Governo Luiz Inácio Lula da Silva, bem como têm forte influência na determinação da agenda de pesquisa da área”. Ver: BARREYRO, G. B. \& ROTHEN, J. C. "O NUPES e a avaliação do ensino superior: concepções, propostas e posicionamentos políticos”. 33a . Reunião Anual da ANPED, 2010, Caxambú, MG. Educação no Brasil: o balanço de uma década, 2010. Disponível em: http://www.anped11.uerj.br/ONUPIS.pdf. Consultado em 07/06/2014.
} 
foi um estudo comparativo das políticas de educação superior na América Latina. O grupo estudado incluía o Brasil, Chile, Argentina, México e a Colômbia. Descobrimos que havia problemas muito semelhantes com soluções muito diversas. Ou, então, que havia soluções muito semelhantes, mas que estavam defasadas. Havia um jogo entre os mesmos problemas que, na verdade, tentava-se resolver de um jeito ou de outro, nesse ou naquele momento, mas com uma tendência muito grande para andar na mesma direção. Depois disso, comecei a estudar particularmente o sistema educacional brasileiro. A partir desse momento, estranhamente, começaram a me considerar uma especialista... O Simon já era um especialista por conta própria. E nesse contexto passei a ser considerada uma especialista em ensino superior também. Dai comecei a ser convidada para dar assessoria e para escrever artigos. O José Goldemberg, quando foi reitor da USP, me convidou para assessorar a reitoria em termos de política universitária, de modo que meu caminho tomou uma direção muito diferente.

Foi como "especialista em educação superior" que, mais tarde, Durham atuou como diretora geral da CAPES, secretária nacional de ensino superior e secretária nacional de política educacional do Ministério da Educação durante o governo Fernando Henrique Cardoso. As atividades desenvolvidas pelo núcleo demonstram que um dos marcos da comunidade docente foi repensar a atuação da universidade diante das novas tarefas impostas pela democracia, recolocando a universidade diante do desafio de estabelecer vínculos entre a realização de pesquisas e o diálogo com a sociedade e com o Estado, quiçá contribuindo para a definição de políticas públicas.

Desde 2005, Moisés passou a coordenar o NUPPs, empreendendo ao núcleo uma direção mais ampla voltada para a cultura política e estudos em torno da desconfiança dos cidadãos brasileiros em relação à democracia. Desde então, Moisés dedicou-se em compreender por que os cidadãos desconfiam das instituições públicas, a pensar os direitos políticos e a consolidação da democracia. Recentemente, o NUPPs iniciou estudos preocupados em traçar um balanço crítico dos 25 anos de existência da democracia no país. Núcleos de pesquisa como o NUPPs tem uma importância muito grande para vencer a especialização a que foram submetidos os departamentos de Ciências Sociais:

Ora, a especialização levou a uma dificuldade de diálogo entre a Ciência Política e a Sociologia. Agora, faz sentido pensar a política longe da sociedade? Faz sentido pensar os desafios da sociedade sem incluir as tarefas do Estado, da esfera pública para tomar decisões? Exemplifico com isso para mostrar porque na minha análise os núcleos de apoio à pesquisa, dos quais o Núcleo de Pesquisa em 
Políticas Públicas (NUPPs) e o Núcleo de Estudos da Violência (NEV) são exemplos. Esses núcleos foram agregando pesquisadores de diferentes áreas, que podem retomar programas de pesquisa com uma integridade e uma perspectiva mais consistente que não existia antes.

A perspectiva apontada por Moisés, contraposta à especialização do conhecimento e a favor de um franco diálogo com a sociedade, permite qualificar o NUPPs e suas pesquisas como parte integrante dos projetos gestados por uma comunidade docente durante o processo de institucionalização acadêmica ocorrida na transição da ditadura para a democracia política. Os vários estudos implementados em torno da questão democrática demonstram o desejo de seus membros em atuar como intelectuais "legisladores" no contexto de uma modernidade radicalizada. Ao realizarem pesquisas que visam identificar as principais falhas do sistema e os mais destacados receios da população brasileira em relação à democracia, o NUPPs pretende contribuir para a elaboração de políticas públicas capazes de fortalecer as instituições democráticas e sua relação com a comunidade. Nesse sentido, os propósitos do NUPPs e de alguns outros núcleos de pesquisa organizados na mesma época, representam a adesão dos intelectuais aos desafios propostos pelo horizonte democrático e às mais variadas posições políticas relacionadas a ele.

Zilda Iokoi, coordenadora do Núcleo de Estudos das Diversidades, Intolerâncias e Conflitos (Diversitas), vinculado à FFLCH-USP e, anteriormente, denominado Laboratório de Estudos sobre a Intolerância (LEI), defendeu a sua criação como um espaço para o cultivo de atividades de pesquisa a partir da interdisciplinaridade. Segundo a professora, a concretização da Faculdade de Filosofia refundada a partir de 1969, em pleno regime militar, havia reduzido a capacidade de debate entre as diferentes áreas do conhecimento. O DIVERSITAS seria, assim, uma oportunidade para reconstruir um importante espaço de diálogo no interior da FFLCH, propiciando a produção de conhecimentos relativos à questão da intolerância e propondo meios de intervenção no espaço público:

Penso que uma tarefa fundamental, que já estávamos realizando no LEI, era a de fazer todo um trabalho de integração entre a pesquisa e as problemáticas sociais. Nós temos intervenções interessantes realizadas no campo da educação com estudos sobre escola, pesquisas sobre materiais didáticos, produção de documentários voltados para o ensino propriamente dito. Temos já uma produção bastante 
interessante para pensar os problemas do planeta, a sobrevida do meio ambiente, os direitos fundamentais da humanidade.

Como parte de uma comunidade docente que foi vitimada pela intolerância e violência cometidas pelo regime militar, Iokoi compreende o DIVERSITAS como um núcleo capaz de fomentar pesquisas e reflexões sobre a história dos movimentos sociais com o objetivo de projetar alternativas de futuro:

Realizamos um projeto sobre memória dos presos políticos com apoio da Ford Foundation, para trazer à cena muito mais daquilo que a memória dessa situação deixou para os familiares e para os próprios presos que sobreviveram, para que possamos pensar as relações entre o curto século vinte, e o longo século XIX. Um tempo que fertilizou a ideia da revolução, da luta, da possibilidade de reversão do capitalismo. As velhas estratégias produzidas no século XIX e as possibilidades da revolução proletária. $\mathrm{O}$ modo de se organizar contra a ditadura seguia essa pauta e esse programa, e hoje a consciência plena de que essas alternativas não cabem mais exigem reflexão crítica para se construir o devir. Então, o que foi viver esse tempo? Que projetos e que sonhos estavam ali contidos? E como foi a violência do Estado? Porque nós temos que saber detalhes, para que possamos lutar contra essa violência. E ainda assim, pensar como vivendo essa experiência, sofrendo tantas dores e luto, se pode pensar de outra maneira a constituição do futuro. Acho que esse é o objetivo do projeto: ao mesmo tempo nos ajudar a entender esse passado, que ainda não está decantado porque há muita coisa que não se sabe a respeito, e também a pensar a institucionalidade das lutas sociais, quais são os seus caminhos e alternativas de futuro.

A recente criação de um programa de pós-graduação em Humanidades, Direitos e Outras Legitimidades, atesta as preocupações do DIVERSITAS em implementar estudos preocupados em compreender a permanência de condutas antidemocráticas e intolerantes na sociedade brasileira contemporânea.

Francisco de Oliveira depois de longa atuação no CEBRAP, centro de estudos instituído para abrigar pesquisadores que tinham sido expulsos da USP, encontrou na Faculdade de Filosofia a possibilidade de criar um centro de pesquisas vinculado à outra espécie de tradição institucional e acadêmica, o CENEDIC:

Foi assim que entrei na USP e tive a felicidade de encontrar um grupo muito interessante que incluía a Prof. ${ }^{a}$ Dr. ${ }^{a}$ Maria Célia Paoli que era a figura mais expressiva. Juntos começamos a formar um grupo de estudos que resultou na criação em 1995 do Núcleo de Estudos dos Direitos e da Cidadania (NEDIC). Mais tarde, por recomendação do 
então diretor da Faculdade de Filosofia, Letras e Ciências Humanas (FFLCH-USP), o Prof. Dr. Francis Aubert, o núcleo se tornou o Centro de Estudos dos Direitos da Cidadania (CENEDIC). Uma vez ligado a FFLCH como um todo, passaria a ter condições de receber maior apoio institucional. Nós sempre nos consideramos amadores, ou seja, amamos o que fazemos. Para nossa surpresa, somos muito bem considerados dentro da universidade. A nossa atividade é muito intensa e produtiva, temos seminários quase semanalmente. Editamos quatro livros a partir de atividades desenvolvidas lá. Enfim, a minha atividade acadêmica na USP deve muito a esse grupo que encontrei e consegui melhorar do ponto de vista de conseguir agregar mais pessoas e contribuir para o desenvolvimento das atividades docentes e de estudos.

Envolvendo diferentes áreas do conhecimento, o CENEDIC promoveu pesquisas e debates em torno do problema do cerceamento do espaço público e da mobilização de novos personagens na cena dos movimentos sociais nas metrópoles. A publicação de $O s$ sentidos da democracia - políticas do dissenso e hegemonia global, livro organizado por Francisco de Oliveira e Maria Célia Paoli, trouxe à tona reflexões que nortearam as pesquisas do CENEDIC em torno da globalização e do avanço das políticas neoliberais. Entre os artigos, merece destaque o redigido por Marilena Chauí "Ideologia neoliberal e universidade", no qual apresentou sérias críticas em relação aos critérios de distribuição de recursos públicos para pesquisa e os princípios de modernização racionalizadora da universidade, posicionando-se frontalmente contra a privatização e terceirização da atividade universitária ${ }^{180}$. Temas que, aliás, serão os próximos a serem abordados pela comunidade docente entrevistada.

\subsection{Diálogo e autonomia: a difícil mediação entre universidade e sociedade.}

As entrevistas evidenciaram que a presença da questão da autonomia universitária ganhou novos contornos durante a democratização política e fomentou um intenso debate no interior da comunidade docente. Depois de décadas de controle autoritário, a construção democrática problematizou ainda mais as relações entre universidade, Estado e sociedade, dividindo opiniões. O velho perigo imposto pelo Estado autoritário

\footnotetext{
${ }^{180}$ CHAUÍ, M. "Neoliberalismo e universidade". In: OLIVEIRA, F. de \& PAOLI, M. C. Os sentidos da democracia - políticas do dissenso e hegemonia global. Rio de Janeiro: Petrópolis, 1999, pp.36-37.
} 
dava lugar a ameaças difusas, aquelas empreendidas pelo mercado e pelos mais variados interesses privados.

Trata-se de uma comunidade que defende a aproximação da universidade pública em relação às necessidades sociais, mas que não concorda com o apelo de determinados setores políticos e negócios particulares, inclusive industriais, que querem otimizar os padrões de resposta da universidade em relação aos investimentos que são realizados em pesquisas. Como ressaltou Matos:

\begin{abstract}
A temporalidade do mercado é o curto prazo, é a política dos resultados. Já o tempo da universidade é longo e ela não pode estar comprometida com as contingências do mercado e do presente. Claro que existem aquelas áreas que vivem das revoluções tecnológicas, mas não é a universidade como um todo que vive assim. A alta pesquisa é derivada de um alto grau de refinamento como a gente pode observar na medicina hoje. Os frutos dessas pesquisas não são circunstanciais e imediatos.
\end{abstract}

$\mathrm{O}$ receio de que a lógica instrumental provoque a reificação das pesquisas e destrua a autonomia da universidade, transformado-a em simples fornecedora de produtos e ou organizadora de eventos sociais de caráter beneficente, é compartilhado pela comunidade docente. Os professores entendem que o fim da autonomia universitária poderia ainda transformar o espaço acadêmico em um campo disputado por governos, grupos econômicos e ou partidos políticos que não poderiam contribuir com a formulação de políticas públicas consistentes que visam à coletividade.

Matos expressou preocupação em relação às novas tarefas que governos tentam impor à universidade, descaracterizando suas atividades de ensino, pesquisa e extensão e mergulhando seus profissionais em relações fluídas e destinadas a ações sociais imediatistas:

Além disso, a USP hoje está sob uma pressão populista como se a universidade pudesse responder às necessidades de um bairro. É preciso ficar claro que a universidade não tem como atender as carências básicas da população. O que uma universidade pode fazer em termos de levar eletricidade, levar saneamento básico, encanamento ou escola? Ela pode sim levar projetos de extensão naquilo que os bairros e as comunidades, através de suas prefeituras e de seus movimentos organizados, requisitam. Agora, a universidade não pode parar de fazer o que ela está fazendo para atender demandas esporádicas. Fica postiço e não funciona. A USP vive esse momento. 
As palavras de Matos refletem inquietações que são comuns a toda a comunidade. O contexto propiciado pela universidade pública e pela institucionalização das carreiras certamente contribuiu para que os docentes articulassem um trabalho acadêmico que procurou resguardar a autonomia universitária e resistir à sua dissolução diante da liquidez do mercado e de suas demandas artificiais. A qualidade de docentes formados em instituições públicas e que conviveram com o lento processo de institucionalização da carreira acadêmica no período de transição política, possibilitou uma avaliação cautelosa em relação às novas possibilidades e meios de atuação diante das necessidades da sociedade na recente democracia brasileira.

Como forma de resistir à instrumentalização das atividades universitárias, Leopoldo e Silva defendeu que a universidade deve ser pensada como uma autarquia e, portanto, precisa necessariamente estabelecer uma relação de mediação com a sociedade e com o poder, sem abandonar a sua condição específica enquanto produtora de saber independente:

O papel da FFLCH sempre foi discutido de maneira muito enviesada. Existem ai duas posições igualmente extremas. Essa questão é análoga àquela que eu comentava a respeito do sacrifício ou não da universidade em prol de uma causa maior. Há aqueles que veem a universidade pública como totalmente voltada para a sociedade e submetida a sua demanda e, de outra maneira, há aqueles que veem a universidade pública no sentido de uma instituição independente de qualquer poder, inclusive das demandas sociais. Acho que há um pouco de idealidade nos dois casos. Ser uma autarquia significa isso, ter uma relação com as demandas sociais e uma relação com o poder, ambas são inevitáveis. Ao mesmo tempo uma autarquia constrói essas relações de tal modo que elas não afetem a independência da Faculdade. É impossível não ter relações com o poder. Seria utópico. Ignorar a sociedade é um absurdo também.

Ajuizada enquanto uma autarquia caberia aos docentes construir uma relação mediada em relação à sociedade, formulando problemas e sugerindo ações dentro da sua alçada, resistindo, portanto, a demandas sociais que não podem ser cumpridas pela universidade $^{181}$. Na concepção de autarquia defendida por Franklin, a universidade tem a obrigação de dialogar com a sociedade, mas não deve se subordinar cegamente à suas expectativas:

\footnotetext{
${ }^{181}$ A questão da universidade enquanto uma autarquia, desenvolvida por Franklin Leopoldo e Silva, foi amplamente discutida por Irene Cardoso. Ver: CARDOSO, I. Para uma crítica do presente. Op. cit., p. 64.
} 
É preciso construir relações mediadas por aquilo que a universidade tem de específico. Não é necessário estar diretamente ligado ao governo, não precisa, a universidade também não está imediatamente submetida às demandas sociais. Nos dois casos é preciso construir mediações que preservam o espaço próprio da universidade e, nesse sentido, ela atende o seu caráter de instituição que tem a ver com o governo e com os impostos que a população paga e também com as demandas sociais que a pressionam enquanto um organismo social. Então a sociedade civil e as demandas de Estado têm de repercutir, mas desde que isso não se torne uma relação de ingerência e subordinação. Para que isso não aconteça proponho essa mediação, o que significa que a universidade deve responder a essas demandas universitariamente. Quando você consegue definir esse caráter você sabe que está desempenhando um papel universitário. Nesse sentido, a questão passa para outro patamar. Alguém pode perguntar: "Mas essa atuação é suficiente?". Bom, se isso não é suficiente, não significa que a universidade deva fazer alguma coisa a mais, mas significa que as outras instâncias não estão fazendo a sua parte. Acho que é um pouco de ilusão achar que a universidade tem que fazer de tudo para suprir demandas sociais. Não, ela faz o que é suficiente no espaço de sua especificidade. Se os outros todos fizerem a mesma coisa, é muito possível que as carências sejam atendidas.

A proposta de mediação formulada por Leopoldo e Silva sintetizou os esforços de toda comunidade docente forjada entre a ditadura e a democracia e redefiniu seus compromissos em relação à universidade pública. A memória coletiva da comunidade docente atesta ainda que os professores empenharam-se ao longo do processo de redemocratização política em redefinir seus papéis enquanto funcionários públicos. Esse trabalho reflexivo propiciou o amadurecimento coletivo de uma concepção de autonomia universitária mediada por um conjunto de experiências vivenciadas desde os tempos ditatoriais e pela necessidade de reconstruir as relações com a sociedade pautadas pelo regime democrático.

A reconstrução da autonomia universitária, segundo Moisés, demandou que a comunidade docente vencesse a desconfiança em relação ao espaço universitário. Mesmo com o fim do Estado ditatorial, muitos professores resistiram em voltar para a universidade por desconfiarem que a autonomia universitária pudesse ser restabelecida a partir da concretização de novas relações com o Estado democrático. Para Moisés, a aposta feita pelos docentes que escolheram manter a realização de trabalhos de pesquisa dentro da universidade pública estava ligada à construção de uma concepção trabalhosa de autonomia que, ambos, professores e regime democrático, passaram a exigir: 
As grandes decisões estão sendo avaliadas, o que significa que aquela inovação introduzida nos anos 80 , abriu um debate em torno de como a universidade se situa diante do fato de ser uma instituição financiada com recursos públicos e compreende a questão da autonomia. Porque a autonomia não significa que ela pode fazer estritamente o que ela quiser. Autonomia diz respeito também ao programa de respostas que ela tem para com a sociedade. Não estou aqui defendendo a ideia de que o governo deveria fazer um plano e entregar para a universidade dizendo: "Vocês tem que fazer isso aqui". Não concordo com essa tese, para mim está claro que a universidade tem que ter autonomia intelectual. Mas a universidade existe em um contexto social. É impossível separar a universidade dos desafios da sociedade. Se a universidade não tiver a capacidade de responder a isso, ela tem que ser questionada.

Dentre os diversos desafios enfrentados pela comunidade docente, o mais vital para a universidade pública foi a resistência empreendida contra a perda de sua autonomia, principalmente diante da intensidade e variedade das cobranças que se acumulavam desde o início do processo de redemocratização. A sua condição enquanto comunidade espremida entre a experiência ditatorial e a democrática possibilitou a renovação do compromisso com a universidade pública enquanto lócus fundamental e parte intrínseca do espaço público. Ainda que existam divergências políticas em relação às prioridades a serem cumpridas e, principalmente, em relação à concepção de como o trabalho acadêmico e a universidade devem ser avaliados - como visto no capítulo anterior, foi possível constatar a negociação de um consenso quanto ao papel indispensável da universidade pública enquanto uma autarquia para o país.

Nesse sentido, a concepção de autonomia universitária compartilhada pela comunidade docente está intimamente vinculada à presença e à importância que a universidade pública possui em sua memória coletiva. Francisco de Oliveira, por exemplo, mencionou a sua experiência de trabalho como docente na Faculdade de Filosofia da USP, compreendendo-a como um espaço de reflexão política, cultivo do bem público e exercício da liberdade:

Entendo que a FFLCH-USP é um local de resistência ao esvaziamento do espaço público. Esse esvaziamento do espaço público que vivemos significa a colonização da política pela economia. Acontece que as duas coisas são diferentes. A economia tem determinações que vem do capital e, às vezes, contra a sua vontade, faz-se aquilo em que não se acredita, mas se é obrigado a fazer. A política não, a política é o exercício da liberdade. Pela política é possível reformar a sociedade. 
Pela economia isso não acontece. Então, geralmente a discussão aqui no Brasil é equivocada porque se pensa que é a economia que determina as coisas, mas, na verdade, é a política. Então, quando se deixa que a economia determine as coisas, a política perde a sua autonomia e os cidadãos também deixam de ser autônomos. Tudo passa a ser decidido de forma determinista pelas necessidades econômicas. A política é o contrário, ela é o lugar e a forma como a sociedade pode corrigir as suas próprias distorções, sem que nenhuma força externa lhe obrigue a isso. Daí a importância da autonomia da política e da resistência ao esvaziamento do espaço público. A FFLCH continua sendo um lugar onde se pode cultivar esse espaço público e onde a atividade política é proeminente.

A posição de Oliveira ressalta a condição peculiar de uma comunidade docente que, superou a desconfiança em relação ao papel ideológico desempenhado pela universidade enquanto aparelho de Estado, e tomou a FFLCH-USP como um local capaz de exercer e cultivar o espaço público e o exercício autônomo da reflexão intelectual e, inclusive, política.

Alguns docentes afirmaram que, graças às condições oferecidas pela universidade pública, sua geração desenvolveu pesquisas e dialogou com as novas exigências ligadas à avaliação docente, sem que houvesse qualquer tipo de interferência nos propósitos estabelecidos pelo trabalho acadêmico. Quando Coggiola afirma que "a universidade pública é a única em que há um sistema de pesquisa", isso significa para a comunidade como um todo, que as investigações afiançadas pelo Estado são o cerce de todo trabalho docente (pesquisa, ensino e extensão) desenvolvido nas instituições públicas. Uma formação baseada em procedimentos ligados à pesquisa leva em conta o domínio dos processos de construção e sistematização do conhecimento, sem os quais, não há saber autônomo e, quiçá, crítico:

A universidade pública é a única em que você pode trabalhar sem as exigências do produtivismo mais elementar. Nas privadas você tem que dar aulas feito um louco. Além disso, a universidade pública é a única em que há um sistema de pesquisa. E isso vale não somente para o Brasil, mas vale para a América Latina e o mundo. Não haveria pesquisa universitária, e diria mais longe, não haveria pesquisa em geral se não fosse pela universidade pública. Por esse motivo as universidades públicas se transformaram praticamente em universidades de pesquisa onde dar aulas é secundário. O professor está aqui para pesquisar e aqui os colegas vão te reconhecer não se você dá uma boa aula, mas vão te reconhecer pela qualidade da sua pesquisa. 
Ao mesmo tempo em que enfatiza a existência do professor pesquisador que muitas vezes, não é valorizado em sua atuação em sala de aula -, Coggiola evidenciou o grande número de instituições particulares que garantem seus rendimentos apropriandose do trabalho desempenhado por professores horistas. Muitas vezes, formados em instituições públicas e capacitados a orientar pesquisas, eles acabam atuando dentro de limites específicos e ensinando conhecimentos previamente elaborados. Nas palavras de Coggiola:

\begin{abstract}
Então tenho uma imagem bastante ampla da universidade brasileira, inclusive do setor privado. Em se tratando dos professores, acho que nós temos aqui uma elite que é a USP, Unicamp e Unesp, uma classe média que são os professores das universidades federais e, depois, uma classe operária que são os "coitados" que dão aulas nas privadas. Com a exceção da PUC, tem os professores do Objetivo, da Anhembi que são os professores horistas que trabalham feito loucos! Esses operários são os alunos mais brilhantes das universidades que saem querendo fazer carreira em uma pública e são obrigados a começar pela Uninove ou Bandeirantes, onde as condições de trabalho são terríveis se comparadas com uma universidade pública. E, acrescentase a isso, o sistema de pesquisa que não existe nessas universidades particulares.
\end{abstract}

$\mathrm{O}$ fato dos professores pertencentes à comunidade docente pesquisada terem acompanhado, desde a segundo metade dos anos 1970, o grande crescimento do setor privado na educação superior e, de alguns deles terem iniciado suas carreiras em instituições dessa qualidade, permitiu que contextualizassem com precisão o significado e a importância da carreira universitária pública para o país.

"Você acha que o capital privado investiria nessas áreas e na geografia que eu faço? Não mesmo, é só olhar por aí”, afirmou Messias da Costa. Para este docente a universidade pública "tem um papel civilizador" que precisa ser pensado em conjunto com outras políticas de Estado. Nesse sentido, Messias da Costa expressa, nada mais nada menos, os conteúdos e as responsabilidades que fazem parte do cerne das preocupações de uma comunidade docente que defende o ensino público como imprescindível para a formulação de projetos de interesse nacional:

A universidade pública e a USP em especial tem toda a importância. Para mim é tudo. Como dizia a minha namorada e atual esposa, que conheci em 1973 no prédio da Geografia e História: "Só falta você dormir aqui!". Em síntese, em países como o nosso é impensável não apoiar a universidade pública. Sobretudo uma universidade como a 
USP que tem ciências pesadas, ciências humanas independentes, tecnologia, medicina avançada, informática, novas engenharias. Você acha que o capital privado investiria nessas áreas e na geografia que eu faço? Não mesmo, é só olhar por aí. A USP é um patrimônio nacional. E não falo pela universidade pública em abstrato, falo pela USP que conheço. A universidade pública teve um papel fundamental na construção de um Brasil moderno. Tenho amigos que são da Federal do Amazonas e do Pará que também foram ajudar a implantar um campus universitário em lugares remotos como Tabatinga, Benjamin Constant, Marabá e Imperatriz. Tenho um amigo que hoje é reitor de uma universidade recém criada em Santarém. Imagine o impacto de uma universidade como a Universidade Federal do Oeste Paraense (UNIFOPA)! Ela é fundamental para a sociedade e para todos aqueles jovens. Então no Brasil a universidade pública tem um papel civilizador.

Foram as condições de trabalho proporcionadas pela universidade pública e as perspectivas de formação e produção intelectual que, portanto, permitiram aos docentes pertencentes à Faculdade de Filosofia escolherem atuar como "legisladores" modernos em um contexto de modernidade radicalizada, de acordo com termos propostos por Bauman. Não se pode ainda desconsiderar o fato da própria democracia política em formação ter demandado a participação dos docentes na esfera pública e cobrado intervenções capazes de contribuir para o aprofundamento da cultura democrática.

A liberdade de investigação e criação foram fundamentais para que os docentes pudessem repensar o seu papel diante das contradições da democracia brasileira e da imensa desigualdade social. Isso significa dizer ainda que, na contramão de perspectivas imediatistas, os docentes da Faculdade de Filosofia reivindicaram a preservação de saberes e conteúdos curriculares clássicos presentes em disciplinas, linhas de pesquisa e trabalhos acadêmicos ${ }^{182}$.

Ao narrar passagens de sua trajetória, Leyla Perrone Moisés apresentou não só detalhes sobre a sua longa experiência de trabalho na universidade pública, como se posicionou de maneira apreensiva em relação ao seu futuro:

O papel da universidade é a pesquisa, o ensino etc. A universidade pública é importante em um país em que tão pouca gente consegue chegar até a universidade... A universidade pública é um espaço de liberdade porque as universidades privadas são empresas. E as empresas sempre visam o lucro, senão elas não são empresas. Mesmo que elas beneficiem a sociedade formando profissionais capacitados

182 Ver: SAVIANI, D. Pedagogia histórico-crítica - primeiras aproximações. Campinas, Autores Associados, 1997. 
em várias áreas, as universidades particulares funcionam segundo a demanda da sociedade e, funcionar de acordo com a demanda significa apenas manter as coisas como elas estão. A universidade pública tem a liberdade de oferecer disciplinas como "Estudos Camonianos", ou seja, de ensinar o que aparentemente não serve para nada.

Ao fazerem parte de uma instituição que exige cotidianamente o usufruto de sua autonomia enquanto parte de uma autarquia - nos termos estabelecidos por Leopoldo e Silva -, os docentes puderam pesquisar e ministrar cursos sobre temas que "de nada valem" e "para nada servem". Ao atribuírem à Faculdade de Filosofia a qualidade de ser um "espaço de liberdade", os professores quiseram demonstrar que ao longo de suas trajetórias acadêmicas desenvolveram pesquisas e ministraram cursos que nunca pretenderam atender a finalidades impetradas pela lógica instrumental.

“Pertenço a uma geração que viveu uma repressão violenta do Regime Militar. Ao mesmo tempo, pertenço a uma geração que ainda teve liberdade dentro da universidade", afirmou Theodoro da Silva. Em um trecho central de sua entrevista, Arrigucci Jr. também procurou defender a importância do espaço acadêmico na construção de sua trajetória intelectual: “A universidade me abriu para o mundo e, ao contrário do que se pensa, ela pode ser muito bem o lugar de liberdade e não o lugar do enquadramento". Tais passagens evidenciam que a Faculdade de Filosofia propiciou uma formação autêntica e original através do diálogo estabelecido pelos professores em formação com a cultura produzida historicamente pela humanidade. Daí a questão da autonomia ter sido fundamental para a constituição das bases empíricas e teóricas que sustentaram e ainda garantem as realizações dessa comunidade docente até os dias atuais.

As lembranças de Perrone-Moisés em relação a uma reunião ocorrida em 2002 na qual se encontrou com o então primeiro ministro francês, o socialista Lionel Jospin, retratam as ameaças sofridas pela autonomia universitária e os perigos que rondam a área de humanidades nos últimos tempos:

A tendência mundial em relação à universidade pública é péssima. As universidades públicas estão resistindo bravamente, mas como tudo, inclusive a saúde, estão tendendo a ser privatizadas... E, enquanto não se privatiza todo o ensino, como tem ocorrido até na França, que já foi um modelo de ensino público gratuito, a universidade vai adquirindo um tipo de pensamento empresarial. Essa tem sido a prática. Cheguei a fazer justamente uma pergunta sobre a universidade pública a Lionel 
Jospin, quando ele era primeiro ministro e esteve aqui no Brasil, em 2002. Ele havia dito que queria debater com alguns intelectuais brasileiros e então a embaixada francesa me chamou para ir ao Rio de Janeiro, para uma mesa redonda com ele. Ele era socialista, muito simpático e muito culto. Lá estava também o Gabeira, alguns cineastas, um pessoal muito bom e, da universidade, só estava eu. Bom, eu havia visto um projeto a respeito da descentralização da universidade francesa, de modo que fossem criados núcleos regionais "em função da demanda de empregos locais". A pergunta que fiz era a seguinte: "Se esses núcleos universitários forem criados em função da demanda de empregos locais, então a gente pode supor que Filosofia e Literatura logo irão desaparecer porque não existe demanda nenhuma por essas áreas?" O Primeiro Ministro respondeu: "Madame, a senhora pensa como uma antiga professora das Letras e das Artes, uma 'sorbonnarde"”.

A resposta do primeiro ministro à Perrone-Moisés qualifica exemplarmente a hipótese da presente tese. Em "tradução" livre, Jospin teria indagado: como pode a senhora não ter atualizado sua concepção sobre as universidades públicas e percebido a importância delas se adequarem às necessidades de mercado? Jospin, evidentemente, sabia que as críticas feitas a seus projetos para o ensino superior provinham de docentes "ultrapassados" que se recusavam em abdicar de sua autonomia intelectual e continuavam defendendo a universidade como uma autarquia.

A comunidade docente estudada aprendeu a valorizar a universidade pública enquanto uma autarquia e a defender a autonomia do trabalho intelectual devido a sua experiência diante do Estado autoritário e das lutas em torno da redemocratização. No contexto brasileiro, as críticas de Perrone-Moisés ao modelo de universidade defendido por Jospin, opõem-se ao crescimento dos interesses que visam inserir a universidade pública na lógica instrumentalizadora formulada pela parceria entre governos e mercados. Ainda nas palavras da professora, a Faculdade de Filosofia e seus projetos de pesquisa e ensino, caminham na contramão das tendências que pretendem enquadrar a universidade pública em uma lógica economicista e instrumental:

Além de me chamar de velha, ele continuou: "Nós precisamos criar empregos na França. Uma universidade em um polo industrial não pode ficar gastando dinheiro público com coisas que não sejam úteis". Isso porque ele era um primeiro ministro socialista! Vamos ver agora o que fará o François Hollande... Mas não tem muito jeito, os Estados estão deixando de existir, eles estão passando a existir apenas formalmente, o que comanda tudo é a economia, então não vejo solução. Eu acho um milagre ainda existir uma Faculdade de 
Filosofia, Letras e Ciências Humanas como a da USP, com os cursos de humanidades que possui.

Ao defender a universidade como uma autarquia, a comunidade docente pertencente à Faculdade de Filosofia no contexto de longa transição da ditadura para a democracia política teve condições de construir uma relação mediada com o Estado e com a sociedade. Para os docentes entrevistados, o espaço de liberdade proporcionado pela Faculdade de Filosofia foi condição indispensável para o desenvolvimento de pesquisas autônomas e a prática de um ensino voltado para a formação humanista e crítica de seus alunos.

Os ingredientes responsáveis pela formação da comunidade docente pertencente à Faculdade de Filosofia fazem parte de uma série de conquistas históricas que constituem os alicerces intelectuais da universidade pública entre o fim da ditadura e a consolidação do regime democrático: formação clássica, profissionalização da carreira acadêmica e autonomia universitária. Para a memória coletiva dos professores, a profissionalização e a estabilidade propiciada pela carreira pública, estiveram atreladas à manutenção da autonomia da universidade pública. Por sua vez, esta ofereceu as condições necessárias para a formação de intelectuais atentos a construção de suas responsabilidades enquanto professores e cidadãos.

Os limites históricos impostos ao espaço público brasileiro e ao acesso à universidade pública, que dificultam a socialização do saber elaborado, redobram as responsabilidades dos docentes da Faculdade de Filosofia. Para Sandra Vasconcelos, diante dos empecilhos estruturais, faz-se necessário reiterar o compromisso com a formação para a cidadania:

Na FFLCH, acho que a palavra formação ainda tem em seu conteúdo forte a questão da formação para a cidadania. É a formação do pesquisador, é a formação para o exercício profissional ou acadêmico, no caso de uma pessoa que tem a intenção de fazer uma carreira acadêmica. A verdade é que o meu sonho em relação ao destino dela seria cumprir essa missão para a qual ela foi criada. Claro que com todas as adaptações que são necessárias em relação aos tempos modernos. Ninguém quer que ela seja exatamente o que ela foi há 70 anos, não é isso. Mas acho que essa ideia da formação é o que nos justifica. De formação de um pensamento crítico, enfim, de alunos que são capazes de argumentar, de dialogar. É por isso que me incomoda a maneira como certos movimentos se criam e se desenvolvem aqui dentro, porque eles abrem mão daquela arma que para nós é fundamental, que é a arma do argumento. Se a gente não formar nosso 
aluno para isso, com a capacidade de pensar, de refletir e de argumentar, acho que de fato a gente falha na nossa missão.

O processo de profissionalização das universidades públicas no Brasil avalizou a estabilidade e a proteção de que precisavam os docentes para desenvolverem pesquisas autônomas e resistirem às pressões produtivistas do mercado e do Estado. Janice Theodoro da Silva foi categórica ao falar da Faculdade de Filosofia enquanto um espaço de exercício livre da crítica:

Na universidade pública tive a liberdade de pensar o que quisesse. Você tem uma estrutura absolutamente burocrática. Tem lá os seus quinquênios, defende uma tese e tem aumento salarial. Isso vai te dando cada vez mais segurança e liberdade! Isso é careta para burro! Mas essa liberdade é um privilégio! Ninguém vai me mandar embora se eu der minhas aulas direito e fizer tudo direitinho! Posso pensar o que quiser. O campo de liberdade que existe dentro da Faculdade de Filosofia da USP é uma coisa de admirável. Nos Estados Unidos, por exemplo, você não tem isso. Você não tem um padrão salarial. Os professores entram naquilo que se chama de "mercado de escravos", não é? Uma universidade oferece um salário maior, a outra não oferece, e o professor circula.

No entanto, sem serem fatalistas, apresentaram preocupações quanto à formação intelectual e profissional das novas gerações de docentes e discentes que farão parte da Faculdade de Filosofia em um futuro próximo. As palavras de muitos docentes soam como um alerta e atestam a necessidade de se valorizar as conquistas estabelecidas nos últimos 40 anos. Como manter as realizações e o ambiente criado e defendido por diferentes gerações diante da radicalização da modernidade e do cerceamento da autonomia universitária?

"O modelo brasileiro cria um campo de liberdade maravilhoso que, infelizmente, com o tempo, tende a acabar! O mundo moderno não admite pausas, ócio", afirmou Theodoro da Silva. Alessandri Carlos também destacou o fato de que a Faculdade de Filosofia não está imune às pressões que pretendem cercear o seu espaço de autonomia, bem como o da universidade pública como um todo:

Não quero ficar presa no passado, mas nós precisamos do passado para levar a FFLCH ao século XXI. Do meu ponto de vista, talvez de forma um pouco resumida, pensar na divisão é essa incompreensão total com o que foi a FFLCH. Ao mesmo tempo, esse desejo reflete um compromisso com um pensamento neoliberal que vigora hoje nessa universidade, produtivista, burocrático e imediatista. E aí o que 
vai acontecer com a FFLCH é que, se ela for por esse caminho, haverá o enfraquecimento do pensamento, da reflexão sobre o mundo que nós vivemos, da potência do pensamento, do pessoal daqui da FFLCH de explicar e de agir sobre o mundo, de criar uma luz na construção de um projeto capaz de transformar essa sociedade em outra coisa. Eu sempre falo do sucesso do BBB, que nos transforma todos em voyers e da própria cidade que se transforma, acabando com os campos de várzea, transformando todos os jogadores de futebol em telespectadores.

Para a memória coletiva da comunidade docente a profissionalização da carreira é tratada como um fenômeno conflituoso, mas não como um problema que encerrou a atividade intelectual em uma carapaça administrativa, determinando o seu confinamento no campus universitário ou ao "silêncio de seus trabalhos acadêmicos". Portadores de uma memória em constante reconstrução, os docentes articulam avaliações do passado a projetos de futuro, como pode ser obervado nas palavras de Alessandri Carlos:

Acho que a FFLCH não pode abdicar de um papel que ela tem com a sociedade, não que ela esteja fora da sociedade, mas dentro da sociedade ela tem um papel importante. Acho que abdicar disso é abdicar da história e, nesse caso, o futuro fica assustador. Mas ainda acredito que aqui ainda tem muitas forças de resistência que podem caminhar numa outra direção, certamente... As resistências não acabam. É isso, contraditoriamente, a gente vai tocando e acreditando que poder fazer a diferença!

Trata-se de uma comunidade docente atenta aos problemas nacionais e preocupada com o devir, bem como com o restabelecimento de projetos que consolidem a presença da universidade pública na sociedade: “A universidade está muito encerrada em si mesma. É preciso trazer para fora, fazer esse conhecimento migrar pelas frestas ou por cima dos muros", afirmou Arrigucci Jr.. O professor lembrou que a Editora da Universidade de São Paulo (Edusp) e o Jornal de Resenhas desempenharam no passado um papel significativo no estabelecimento de um forte diálogo entre universidade e sociedade: "O Jornal de Resenhas, por sua vez, nasceu em torno de vários departamentos da FFLCH que integrava e lembrava de novo o velho espírito da Faculdade que era o de cruzar os discursos", completou Arrigucci Jr.. Segundo sua análise, é sempre possível romper com o isolamento intelectual desde que sejam tomadas as medidas adequadas: 
A leitura é o instrumento que nos permite decifrar e aprender. Há carência nesse sentido por lá; as pessoas têm reclamado e noto que são poucos os professores de grande influência e cujo discurso público tem projeção e fala para fora dos muros da universidade - o intelectual público propriamente -, a maioria é formada por intelectuais intramuros. Ou seja, a universidade está muito encerrada em si mesma.

O percurso da comunidade acadêmica formada por docentes que herdaram dos embates enfrentados nos anos 1960 e 1970 valores atrelados à brasilidade revolucionária e, ao mesmo, à formação de um senso crítico em relação ao nacionalismo e ao populismo - que também embasou suas posições em relação ao Estado -, foi muito peculiar. O caldo político, cultural e institucional que deu origem a essa comunidade, portanto, fortaleceu suas concepções em relação à importância da universidade pública e foi decisivo na adoção de responsabilidades em relação ao espaço público.

O diálogo em torno da questão democrática e do papel dos novos movimentos sociais inseriu os docentes pertencentes à Faculdade de Filosofia na recomposição e reconstrução da res pública. Nesse sentido, as análises que procuraram disseminar a ideia de um suposto "fim dos intelectuais públicos" ou, ainda, enfatizar negativamente os processos que levaram à sua profissionalização, não foram capazes de explicar a complexidade das novas relações estabelecidas pelos intelectuais e o surgimento de diferentes formas de inserção no contexto democrático.

O exame das trajetórias de vida acadêmica dos docentes pertencentes à Faculdade de Filosofia permitiu observar a construção de novos meios e formas de alcançar o espaço público a partir da universidade, dentre as quais se destacaram a formação de novas linhas de pesquisa, grupos de estudos e núcleos de pesquisa. Emoldurados pelas novas circunstâncias históricas, esses locais foram resultado de uma combinação de fatores ligados tanto à profissionalização da vida acadêmica, como também fizeram parte das novas relações estabelecidas entre os docentes e a construção da democracia. Nesse sentido, o espaço universitário e as carreiras públicas passaram a ser concebidas pela comunidade docente como uma oportunidade para pensar a sociedade brasileira de maneira autônoma. Além disso, os docentes puderam avaliar as posições ocupadas tradicionalmente pelos intelectuais e repensar o seu próprio papel diante das transformações políticas ocorridas no país.

Os papéis assumidos pelos docentes da Faculdade de Filosofia, dessa maneira, precisam ser entendidos para além dos limites impostos pelo processo de 
institucionalização da carreira acadêmica. Ao invés de restringir a formação e o desenvolvimento de um pensamento independente, a universidade pública garantiu as condições necessárias para a reconstrução de um diálogo com a comunidade diante da (re)democratização política e da lenta construção da cidadania no país ainda em curso.

A trajetória de Francisco de Oliveira, mesmo sendo uma das mais peculiares dentre os docentes entrevistados, sintetiza as mudanças de perspectiva que atingiram os intelectuais nos últimos quarenta anos. Crítico contumaz em relação às "aves de arribação" no clássico texto publicado em 1984, Oliveira veio a se integrar à carreira acadêmica e à condição de funcionário público da Universidade de São Paulo ainda nos anos 1980 e, nem por isso, perdeu a sua inserção no meio político e na esfera pública como intelectual contestativo. Em sua entrevista, demonstrou como fez uso das ferramentas universitárias disponíveis para fundar o CENEDIC. No interior da universidade, a partir de sua atuação como professor, orientador e coordenador desse núcleo de pesquisa, articulou em conjunto com outros pesquisadores a costura entre investigação acadêmica e uma crítica às políticas públicas de Estado em pauta no país.

Perguntado a respeito do seu papel enquanto professor da Faculdade de Filosofia, Oliveira respondeu categoricamente: "inocular o vírus da crítica". Preocupado com a dimensão pedagógica de seu trabalho, defendeu que somente uma concepção de ensino e pesquisa baseada na crítica econômica, política e social possibilita a formação de pesquisadores capazes de interrogar criticamente e de maneira autônoma o seu próprio tempo. Nesse sentido, a FFLCH-USP foi interpretada por Oliveira como um espaço de liberdade e de formação de intelectuais capazes de atuar no espaço público de maneira inovadora:

Quanto a FFLCH acho que ela faz a sua parte de maneira bem feita. A minha principal preocupação como professor é inocular o vírus da crítica. Essa é uma espécie de vírus que pega e nunca mais te larga! O pensamento crítico deveria ser a orientação geral, a preocupação de mostrar para o aluno as contradições da sociedade e tirar-lhe da cabeça qualquer ilusão perigosa de homogeneidade, neutralidade e de uma "postura científica"... A ciência não é isso. A ciência toma posições. Há uma frase excelente de ninguém menos do que Albert Einstein que diz: "Deus não joga com dados". Quer dizer, não é o azar, é a vontade de homens e mulheres conduzindo certos processos sociais que transformam os processos políticos. Esse é o egresso da FFLCH que eu idealizaria: com capacidade crítica voltada para transformar o existente em algo melhor. 
Ademais, enquanto funcionários públicos de carreira, os docentes desfrutaram de plena autonomia ao longo do processo de democratização política. Muitos aproveitaram essa segurança para se licenciarem provisoriamente e desempenharem várias funções, tais como: atuando como assessores no interior de partidos políticos, assumindo posições dentro da estrutura de poder federal, estadual e/ou municipal e trabalhando em agências fomentadoras de recursos para pesquisas. Houve também quem preferiu assumir posições de comando na própria universidade ou, ainda, optou por uma dedicação exclusiva à orientação de grupos de estudos e na criação e aprofundamento de linhas de pesquisa originais. A obrigação de atuar em docência, pesquisa e na administração, garantiu o aprendizado de uma visão ampla da universidade e, ao mesmo tempo, não impediu que os docentes construíssem uma carreira autônoma, singular e com características próprias.

Por mais particulares que sejam as ênfases adotadas em suas carreiras, todos os casos refletem comumente uma relação de profunda dependência em relação à universidade pública o que, paradoxalmente, foi essencial para o desenvolvimento de sua ampla autonomia intelectual. Afinal, as decisões tomadas no plano político somente foram possíveis graças à condição de segurança garantida pela esfera do poder público.

A preocupação em tornar o diálogo com a sociedade mais consistente instruiu a comunidade docente desde a revitalização da democracia e inscreveu na ordem do dia os temas que dão identidade a esses intelectuais: defenderam a universidade como uma autarquia, compreenderam a pesquisa enquanto meio necessário para ensinar os processos de elaboração e sistematização do conhecimento, afirmaram a autonomia de seus trabalhos em relação ao Estado e às demandas sociais e, enquanto professores, cultivaram o pensamento e a formação do senso crítico entre os alunos.

A condição de funcionários públicos de carreira contribuiu para que esses intelectuais conservassem algumas características próprias aos produtores culturais modernos em um contexto de radicalização das contradições presentes na modernidade, dentre elas, a capacidade de reivindicar sua inserção pública. Entre a ditadura e a democracia, forjou-se uma comunidade docente que ainda almeja que os conhecimentos por ela elaborados sejam capazes de interferir nos destinos da vida social brasileira. 


\section{Apontamentos Finais}

As memórias elaboradas pelos docentes no decorrer das entrevistas realizadas revelaram aspectos relativos às relações profissionais estabelecidas no cotidiano acadêmico e também a maneira como as redes de afinidade política e intelectual negociaram a construção de uma memória coletiva.

As trajetórias dos professores titulares, desde a sua formação básica realizada em escolas públicas ou religiosas, passando pela resistência contra o golpe e a ditadura civil-militar e, particularmente, nas lutas em torno da democratização, conferiram uma identidade comum à comunidade. A inserção dos professores no universo acadêmico ocorreu em um contexto de hegemonia do horizonte cultural romântico e revolucionário e, por sua vez, o ápice de suas carreiras foi atingido durante o refluxo das concepções revolucionárias e da introdução da questão democrática.

Os docentes ponderaram sobre a condição de titular como o resultado e a concretização de todo um trabalho dedicado ao ensino, à pesquisa e extensão universitária. Além disso, a "titulatura" representa para a comunidade docente a conquista de prestígio acadêmico junto a seus pares, particularmente no que diz respeito à competência intelectual na elaboração de pesquisas e na capacidade em deixar um legado teórico original. Aliás, muitos titulares fizeram menção aos orientandos que dão continuidade às linhas de pesquisa por eles inauguradas, tanto na Faculdade de Filosofia, quanto em instituições públicas e particulares por todo o país.

Do ponto de vista institucional, a condição de titular implica em ser reconhecido como funcionário público exemplar com aptidão para desempenhar as tarefas mais importantes na esfera administrativa e na política universitária. Afinal, os titulares devem suportar uma carga extra de responsabilidades acadêmicas por possuírem a maior quantidade de cadeiras nas Congregações das Faculdades e no Conselho Universitário, sendo os únicos que podem concorrer à reitoria.

As entrevistas permitiram ainda, explorar os interditos presentes nos discursos acadêmicos e as contradições de um cotidiano burocratizado, marcado pela cientificidade de argumentos em defesa de uma suposta neutralidade. As divergências de ordem política e institucional, no entanto, não impediram que a comunidade docente reivindicasse em uníssono a autonomia intelectual. Esta foi responsável pela produção 
de uma cultura crítica e de oposição, comprometida com as mais variadas vertentes políticas, que visavam o desenvolvimento de políticas públicas e o aprofundamento da cidadania.

Por meio das entrevistas foi possível compreender como os docentes que participaram ativamente da reintrodução da questão democrática, combateram o autoritarismo imposto pelas cátedras e, fora da universidade, trabalharam pela construção de novos espaços políticos. Nesse sentido, a análise das trajetórias acadêmicas revelou que a profissionalização da carreira possuiu um caráter ambivalente: ao mesmo tempo em que enquadrou os professores em um novo sistema de pós-graduação - cuja perspectiva de implantação era abertamente tecnicista -, assegurou-lhes uma carreira com a garantia de estabilidade e dedicação exclusiva. Paradoxalmente, foi a nova carreira docente implantada durante a ditadura que galvanizou o terreno para que os professores pudessem resistir e lutar por melhores condições de trabalho e, posteriormente, participar ativamente da reconstrução das instituições democráticas.

A constituição da autonomia intelectual teve início em plena ditadura militar e se afirmou conforme a cultura acadêmica das cátedras foi extinta, através da consolidação dos concursos públicos no período de redemocratização política. Os concursos possibilitavam, assim, o início de uma democratização institucional da universidade, no sentido que os catedráticos deixavam de controlar os departamentos. Mas, da mesma forma que a transição política, a introdução de uma nova cultura acadêmica foi controlada pelo Estado através da nomeação de reitores firmemente comprometidos com as esferas de poder.

A autonomia intelectual reivindicada unanimemente pelos docentes tem seus pilares assentados na carreira pública. As trajetórias de vida contempladas pela pesquisa demonstraram que a institucionalização das carreiras acadêmicas não exilou os docentes do espaço público, muito pelo contrário, a redemocratização os impulsionou a exercerem papéis políticos nas mais diferentes esferas. Muitos, inclusive, aproveitaram positivamente as mudanças institucionais e criaram linhas de pesquisa, núcleos de estudos, aceitaram participar da esfera governamental, estreitaram vínculos partidários e, até mesmo, passaram a assessorar candidaturas.

Durante a transição política, os professores da FFLCH mantiveram um trabalho silencioso e atrelado às responsabilidades impostas pela burocracia universitária, mas 
não menos atinado às questões trazidas pelo processo de redemocratização. Aliás, tiveram um papel fundamental durante a reintrodução da questão democrática, participando ativamente de debates decisivos. No entanto, a profissionalização acadêmica que atraía recursos financeiros e alento para as carreiras, também impôs um novo e duríssimo regime de trabalho. No final dos anos 1980, a expansão do regime de tempo integral e a ampliação dos concursos públicos foram acompanhadas de uma cobrança cada vez mais intensa por resultados mensuráveis. A carreira universitária e a segurança de um emprego estável apresentaram como contratempo um número cada vez maior de cobranças burocráticas. Para muitos docentes, as novas exigências impostas ao espaço acadêmico passaram a circunscrever o horizonte de ação dos docentes, limitando o antigo modo artesanal de fazer pesquisas e impedindo-os de desfrutar de prazos compatíveis com a produção de conhecimento na esfera das humanidades.

As entrevistas apresentaram uma comunidade que conviveu com embates, choques entre cenários políticos diversos, favorecendo a construção de uma comunidade marcada pela autorreflexão. A condição de funcionários públicos e a profissionalização da carreira não resultaram numa situação confortável para esses intelectuais no regime democrático. Afinal, como muitos professores relataram, a academia passou a ser cobrada quanto à finalidade pública dos conhecimentos por ela produzidos e, ao mesmo tempo, em relação à qualidade, a quantidade e a inserção nacional e internacional de suas publicações.

A redefinição dos projetos coletivos e o investimento nas carreiras individuais foram as principais consequências acarretadas pelo processo de profissionalização acadêmica. Do ideário original de uma Faculdade de Filosofia, Ciências e Letras, sobreviveu o legado de uma comunidade docente que defende unanimemente a autonomia universitária e a importância do ensino público. Além disso, as histórias de vida revelaram que a luta política comum travada no combate à ditadura e expressa pelas memórias relativas à repressão, transformou-se a partir da transição democrática na busca por caminhos políticos independentes. As divergências entre os docentes se tornaram mais nítidas e interferiram na configuração de uma pauta em torno das responsabilidades públicas assumidas pelos intelectuais.

A carreira acadêmica desenvolvida a partir do período democrático permitiu que os docentes optassem por desempenhar papeis diferentes e avaliassem a melhor forma de atuação intelectual. As diversas ênfases adotadas pelas trajetórias de vida indicam 
que os professores desfrutaram efetivamente da liberdade conferida pela Faculdade de Filosofia. Mais do que uma resposta precisa a respeito de qual deveria ser o papel ideal do intelectual no mundo contemporâneo, os professores demonstraram que o verdadeiro usufruto da autonomia significou ter a liberdade de escolher as atividades desenvolvidas enquanto funcionários públicos.

Mesmo reconhecendo que o "mundo contemporâneo é impróprio para os intelectuais como legisladores", como definiu Bauman, a comunidade estudada conservou muitos dos seus atributos sem desprezar, contudo, as características que permitem o desempenho de atividades como "intérpretes". Em um contexto no qual o mercado e, às vezes o Estado, tomam para si as funções de "formulador de opinião e verificador de valores", a comunidade docente recusa o melancólico papel de observador distante e neutro diante dos acontecimentos.

Ao defenderem a universidade pública e uma concepção humanista de ciência, os professores pertencentes à comunidade docente da FFLCH-USP situam-se na condição de produtores modernos de conhecimento em um contex to de modernidade radicalizada. O papel público dos intelectuais permeia a memória coletiva dos docentes tanto quanto a missão formadora e crítica da Faculdade de Filosofia e sua participação na produção do saber humanista e de reflexões sobre o espaço público. As incertezas impostas pela modernidade radicalizada contrastam com o comportamento dos professores que resistem em sustentar princípios considerados incômodos, como o ideal do ensino público e do compromisso com a formação crítica.

$\mathrm{O}$ fato de terem vivido diretamente a experiência da ditadura, em particular a repressão que se abateu sobre a Faculdade de Filosofia da USP e, posteriormente, as rearticulações políticas que deram sustentação à construção democrática, conferem a esses professores titulares uma autoridade acadêmica particular e um desejo de interferir na vida pública. A comunidade docente formada entre a ditadura e a democracia pode, enfim, ser definida como um conjunto de personagens em busca de uma narrativa moderna no contexto da modernidade radicalizada. 


\section{Referências Bibliográficas}

ADUSP. O controle ideológico na USP (1964-1978). São Paulo: ADUSP, 2004.

ALMADA, I. Teatro de Arena - uma estética de resistência. São Paulo: Boitempo, 2004.

ALMEIDA, M. H. T. de. Tomando partido, formando opinião - cientistas sociais, imprensa e política. São Paulo: Sumaré, 1992.

ARANTES, P. Um departamento francês de ultramar: estudos sobre a formação da cultura filosófica uspiana - uma experiência nos anos 60. São Paulo: Paz e Terra, 1994.

Arquidiocese de São Paulo. Brasil: Nunca Mais. Petrópolis: Vozes, 1985.

ARRIGUCCI JÚNIOR, D. Achados e Perdidos - ensaios de crítica. São Paulo: Polis, 1979.

ARRUDA, M. A. do N. Metrópole e Cultura - São Paulo no meio século XX. Bauru, EDUSC, 2001.

BARREYRO, G. B. \& ROTHEN, J. C. “O NUPES e a avaliação do ensino superior: concepções, propostas e posicionamentos políticos". In: 33ª Reunião Anual da ANPED, 2010, Caxambú, MG. Educação no Brasil: o balanço de uma década, 2010, p. 1-16. Disponível em: http://www.anped11.uerj.br/ONUPIS.pdf.

BASTOS, E. R., RIDENTI, M. \& ROLLAND, D. (Orgs.) Intelectuais: sociedade e política: França-Brasil. São Paulo: Cortez, 2003.

BAUMAN, Z. Legisladores e Intérpretes - sobre modernidade, pós-modernidade e intelectuais. Rio de Janeiro: Zahar, 2010.

. Modernidade Líquida. Rio de Janeiro: Zahar, 2001.

BENJAMIN, W. Magia e técnica, arte e política. Ensaios sobre literatura e história da cultura. São Paulo: Brasiliense, 1987. 
BEZERRA DE MENEZES, U. “A História, Cativa da Memória? Para um mapeamento da memória no campo das Ciências Sociais". Rev. Instituto de Estudos Brasileiros. SP, 34, 1992, p. 9-24.

BOSI, A. "Prefácio". In: MOTA, C. G. Ideologia da Cultura Brasileira. São Paulo: Ática, 1977.

"Cultura Brasileira e Culturas Brasileiras". In: . Dialética da colonização. São Paulo: Companhia das Letras, 1992, p.308-345.

BUARQUE DE HOLLANDA, H. \& GONÇALVES, M. A. "A Ficção da realidade brasileira". In: NOVAES, A. (Org.) Anos 70: ainda sob a tempestade. Rio de Janeiro: Aeroplano: Editora Senac Rio, 2005.

CARdoso, I. A Universidade da Comunhão Paulista - o projeto de criação da Universidade de São Paulo. São Paulo: Autores Associados, 1982.

. Para uma crítica do presente. São Paulo: Ed. 34, 2001.

CARVAlO, J. M. Cidadania no Brasil: o longo caminho. Rio de Janeiro: Civilização Brasileira, 2006.

CATANI, A. \& DOURADO, L. F. Universidade Pública - Políticas e identidade institucional. Campinas: Autores Associados, 1999.

CATANI, A. M., SILVA JÚNIOR., J. R. \& MENEGHEL, S.M.. (Orgs.) A cultura da universidade pública brasileira. São Paulo: Xamã, 2011.

CHAUÍ, M. S. Cultura e Democracia: o discurso competente e outras falas. São Paulo: Cortez, 2001.

CUNHA, L. A. A universidade reformanda. Rio de Janeiro: Francisco Alves, 1988.

FÁTIMA DE PAULA, M. de. A modernização da universidade e a transformação da intelligentzia universitária. Florianópolis: Insular, 2002.

FÁVERO, M. de L. A. "A universidade no Brasil: das origens à Reforma Universitária de 1968”. In: Educar, Curitiba, n. 28, 2006, p. 17-36. 
FERNANDES, F. Universidade brasileira: reforma ou revolução? São Paulo: AlfaOmega, 1975.

A Sociologia no Brasil - contribuição para o estudo de sua formação e desenvolvimento. Petrópolis: Vozes, 1976.

A condição de sociólogo. São Paulo: Hucitec, 1978.

. Nova República? Rio de Janeiro: Zahar, 1986.

O Desafio Educacional. São Paulo: Cortez, 1989.

FERREIRA, M. de M. \& AMADO, J. Usos e Abusos da História Oral. Rio de Janeiro: FGV, 1996.

FONTANA, J. História: análise do passado e projeto social. Bauru: EDUSC, 2003.

FRIGOTTO, G. A produtividade da escola improdutiva. São Paulo: Cortez, 1993. Educação e a crise do capitalismo real. São Paulo: Cortez, 2000.

GALVÃO, W. N. Saco de gatos: ensaios críticos. São Paulo: Duas Cidades, 1976. Gatos de outro saco. São Paulo: Brasiliense, 1981.

GASPARI, E., VENTURA, Z. \& HOLLANDA, H. B. de. Cultura em trânsito 70/80: da repressão à abertura. Rio de Janeiro: Aeroplano, 2000.

GENTILI, P. \& APPLE, M. Pedagogia da exclusão: crítica ao neoliberalismo em educação. São Paulo: Vozes, 1997.

GENTILI, P. \& SILVA, T. T. (Orgs.). Escola SA. Brasília: CNTE, 1994.

GENTILI, P. \& SILVA, T. T. (Orgs). Neoliberalismo, qualidade total e educação. Petrópolis: Vozes, 1995.

GIDDENS, A. As consequências da modernidade. São Paulo: Unesp, 1991.

GRELE, R. J. Envelops of Sound: the Art of Oral History. Westport, Connecticut: Praeger, 1991. 
GUSDORF, G. "Condiciones y limites de la autobiografia”. In: ANTHROPOS, la autobiografia y sus problemas teóricos: estúdios e investigación documental $\mathrm{n}^{\text {o }} 29$, 1991.

HALBWACHS, M. A memória coletiva. São Paulo: Vértice, 1990.

HARVEY, D. A Condição Pós-Moderna. São Paulo: Loyola, 1992.

HOBSBAWM, E. Era dos extremos - o breve século XX (1914-1991). São Paulo: Cia das Letras, 1995.

. Sobre a História. São Paulo: Cia das Letras, 2005.

Tempos Fraturados - cultura e sociedade no século XX. São Paulo: Cia das Letras, 2013.

IANNI, O. Sociologia da Sociologia - o pensamento sociológico brasileiro. São Paulo, Ática, 1989.

. O Compromisso com a Universidade. São Paulo: Humanitas/ FFLCH-USP, 1999.

- "Florestan Fernandes e a formação da sociologia brasileira". In: Pensamento Social no Brasil. Bauru: EDUSC, 2004, p. 307-348.

JACOBY, R. Os últimos intelectuais - a cultura americana na era da academia. São Paulo: Edusp, 1990.

O fim da utopia: política e cultura na era da apatia. Rio de Janeiro: Record, 2001.

KEINERT, F. C. Cientistas Sociais entre ciência e política (Brasil: 1968-1985). Universidade de São Paulo, 2011. Tese de doutorado apresentada à FFLCH.

KINZO, M. D. G. Oposição e autoritarismo - gênese e trajetória do MDB (1966-1979). São Paulo: Vértice, 1988.

KOSÍK, K. Dialética do concreto. Rio de Janeiro: Paz e Terra, 2010.

KUCINSKI, B. K. São Paulo: Expressão Popular, 2013. 
LAHUERTA, M. "Intelectuais e resistência democrática: vida acadêmica, marxismo e política no Brasil”. Cadernos Arquivo Edgard Leuenroth (UNICAMP), v. 8, 2001, p. 53-95.

LEVINE, R. Pai dos Pobres? O Brasil e a Era Vargas. São Paulo: Cia das Letras, 2001.

LÖWY, M. \& SAYRE, R. Revolta e Melancolia: o romantismo na contramão da modernidade. Petrópolis: Vozes, 1995.

LÖWY, M. Para uma sociologia dos intelectuais revolucionários. São Paulo: LECH, 1979.

MARTINS, J. de S. A sociologia como aventura - memórias. São Paulo: Contexto, 2013.

MATOS, O. F. C. "Memória e História". In: A Terceira Idade (SESC-São Paulo). São Paulo, Ano 4, n 6, out. 1992.

. “A Educação e a Produção de Saberes e Olhares". In: PRADO, M. L. C. \& VIDAL, D. G. À Margem dos 500 anos: Reflexões Irreverentes. São Paulo: Edusp, 2002.

- Benjaminianas: cultura capitalista e fetichismo contemporâneo. São Paulo: Unesp, 2010.

MEIHY, J. C. S. B. Colônia brasilianista - História Ora de Vida Acadêmica. São Paulo: Nova Stella, 1990. . (Re) Introduzindo a história oral no Brasil. São Paulo: Xamã, 1996. . Manual de História Oral. São Paulo: Loyola, 2005.

MÉSZÁROS, I. A educação para além do Capital. São Paulo: Boitempo, 2005.

MOTTA, R. P. S. “A modernização autoritário-conservadora nas universidades”. In: AARÃO REIS FILHO, D. \& RIDENTI, M. \& MOTTA, R. P. S. (Orgs.) A ditadura que mudou o Brasil: 50 Anos do golpe de 1964. Rio de Janeiro: Zahar, 2014, p. 48-65.

NAPOLITANO, M. Cultura e Poder no Brasil Contemporâneo (1977/1984). Curitiba: Juruá, 2002. 
1964: História do regime militar brasileiro. São Paulo: Contexto, 2014.

NOVAES, A. (Org.). Anos 70: ainda sob a tempestade. Rio de Janeiro: Aeroplano: Editora Senac Rio, 2005.

O silêncio dos intelectuais. São Paulo: Cia das Letras, 2006.

OLIVEIRA, F. “Aves de Arribação: a migração dos intelectuais". In: Lua Nova, vol.2, nº.3, São Paulo, Dec. 1985, p. 20-26.

OLIVEIRA, F. de \& PAOLI, M. C. Os sentidos da democracia-políticas do dissenso e hegemonia global. Rio de Janeiro: Petrópolis, 1999.

ORTIZ, R. "Estudos culturais”. In: Tempo Social, São Paulo, v. 16, n. 1, Jun. 2004, p. 119-127.

Cultura Brasileira e Identidade Nacional. São Paulo: Brasiliense, 2006.

OSBORNE, P. (Ed.) A Critical Sense - interviews with intellectuals. London: Routledge, 1996.

PASSERINI, L. A memória entre política e emoção. São Paulo: Letra e Voz, 2011.

PÉCAUT, D. Os intelectuais e a política no Brasil - entre o povo e a nação. São Paulo: Ática, 1990.

PELLEGRINI, T. “A cultura brasileira em tempo de mídia e mercado". Horizontes, Bragança Paulista, v. 15, 1997, p. 325-335.

POLLAK, M. "Memória e identidade social". In: Estudos Históricos, Rio de Janeiro, vol. 5, n. 10, 1999, p. 200-212.

PORTELLI, A. The Death of Luigi Trastulli and other Stories - Form and Meaning in Oral History. New York: State University of New York Press, 1991.

RIBEIRO, R. J. Humanidades - um novo curso na USP. São Paulo: Edusp, 2001. RIDENTI, M. Professores e Ativistas da Esfera Pública. São Paulo: Cortez, 1995. Em Busca do Povo Brasileiro - artistas da revolução, do CPC à era da TV. Rio de Janeiro: Record, 2000. 
Brasilidade revolucionária: um século de cultura e política. São Paulo: Unesp, 2010 .

RODRIGUES, L. S. A produção social do marxismo universitário em São Paulo: mestres, discípulos e um seminário (1958-1978). Tese de doutorado apresentada à FFLCH-USP, 2011.

ROMANELLI, O. de O. História da Educação no Brasil. Petrópolis: Vozes, 1984.

SADER, E. Quando novos personagens entram em cena. Rio de Janeiro: Paz e Terra, 1995.

SAES, D. A. M. Democracia. São Paulo: Ática, 1987.

SANTOS, M. C. L. dos. (Org.) Maria Antônia: uma rua na contramão. São Paulo: Nobel, 1988.

SAVIANI, D. Escola e Democracia. São Paulo, Autores Associados, 1989.

_. Pedagogia histórico-crítica - primeiras aproximações. Campinas, Autores Associados, 1997.

. A Pedagogia no Brasil: história e teoria. Campinas: Autores Associados, 2008.

SCHWARTZMAN, S. Formação da comunidade científica no Brasil. São Paulo: Nacional, Rio de Janeiro: Finep, 1979.

SCHWARZ, R. Cultura e política, 1964-1969. São Paulo: Paz e Terra, 2009.

SEVCENKO, N. A corrida para o século XXI - no loop da montanha-russa. São Paulo: Cia das Letras, 2001.

SILVA, J. T. Raízes da Ideologia do Planejamento. Nordeste (1889-1930). São Paulo: Livraria Ciências Humanas, 1978.

SILVA, T. T. (Org.) Identidade e diferença: a perspectiva dos estudos culturais. Rio de Janeiro: Vozes, 2000. 
Escola S. A. Quem ganha e quem perde no mercado educacional do neoliberalismo. Brasília: Confederação Nacional dos Trabalhadores em Educação, 1996.

SORJ, B. A construção intelectual do Brasil contemporâneo. Rio de Janeiro: Zahar, 2001.

A nova sociedade brasileira. Rio de Janeiro: Jorge Zahar, 2006.

TAVARES, M. C. \& FIORI, J. L. (Des) ajuste global e modernização conservadora. Rio de Janeiro: Paz e Terra, 1993.

THOMPSON, E. P. Writings by Candlelight. London: Merlin, 1980.

WEFFORT, F. "Novas democracias. Que democracias?" In: Lua Nova, n. 27, São Paulo, Dec. 1992, p. 5-30.

WITTER, J. S. USP/50 Anos: registros de um debate. São Paulo: Edusp, 2006. 